\title{
De huid vanzelfsprekend bewonen : literair existentialisme en mystiek bij Ellen Warmond
}

Citation for published version (APA):

van Wijk, G. M. J. A. (2003). De huid vanzelfsprekend bewonen : literair existentialisme en mystiek bij Ellen Warmond. [Doctoral Thesis, Maastricht University]. Datawyse / Universitaire Pers Maastricht. https://doi.org/10.26481/dis.20030919gw

Document status and date:

Published: 01/01/2003

DOI:

10.26481/dis.20030919gw

Document Version:

Publisher's PDF, also known as Version of record

\section{Please check the document version of this publication:}

- A submitted manuscript is the version of the article upon submission and before peer-review. There can be important differences between the submitted version and the official published version of record.

People interested in the research are advised to contact the author for the final version of the publication, or visit the DOI to the publisher's website.

- The final author version and the galley proof are versions of the publication after peer review.

- The final published version features the final layout of the paper including the volume, issue and page numbers.

Link to publication

\footnotetext{
General rights rights.

- You may freely distribute the URL identifying the publication in the public portal. please follow below link for the End User Agreement:

www.umlib.nl/taverne-license

Take down policy

If you believe that this document breaches copyright please contact us at:

repository@maastrichtuniversity.nl

providing details and we will investigate your claim.
}

Copyright and moral rights for the publications made accessible in the public portal are retained by the authors and/or other copyright owners and it is a condition of accessing publications that users recognise and abide by the legal requirements associated with these

- Users may download and print one copy of any publication from the public portal for the purpose of private study or research.

- You may not further distribute the material or use it for any profit-making activity or commercial gain

If the publication is distributed under the terms of Article $25 \mathrm{fa}$ of the Dutch Copyright Act, indicated by the "Taverne" license above, 
DE HUID VANZELFSPREKEND BEWONEN 
O G.M.J.A. van Wijk, Bergen (NH) 2003

Universitaire Pers Maastricht ISBN 90-5278-387-X

Vormgeving en druk: Datawyse / Universitaire Pers Maastricht 


\title{
DE HUID VANZELFSPREKEND BEWONEN
}

literair existentialisme en mystiek bij Ellen Warmond

\author{
PROEFSCHRIFT \\ ter verkrijging van de graad van doctor aan \\ de Universiteit Maastricht, \\ op gezag van de Rector Magnificus, \\ Prof. dr. A.C. Nieuwenhuijzen Kruseman \\ volgens het besluit van het College van Decanen, \\ in het openbaar te verdedigen \\ op vrijdag 19 september 2003 om 12.00 uur \\ door
}

Geertruida Maria Johanna Alida van Wijk

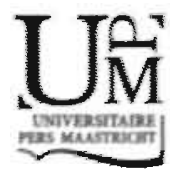




\section{Promotores:}

Prof. dr. W. Kusters

Mw. Prof. dr. M.J.H. Meijer

\section{Beoordelingscommissie:}

Prof. dr. G.A.M. Widdershoven (voorzitter)

Prof. dr. H. Brems (Katholieke Universiteit Leuven)

Prof, dr. F.M. Doorman (Vrije Universiteit Amsterdam)

Mw. Prof. dr. FJ.M. de Feijter (Katholieke Universiteit Nijmegen)

Mw. dr. E. Wesseling 
Voor Maaike van der Lende

kiezen naast ja en nee voor het misschien

met open ogen

in de leegte zien.

Ellen Warmond 



\section{INHOUDSOPGAVE}

Inleiding [ 11]

1. Nederland en het literaire existentialisme

1. Een absurd probleem?

2. Hoe bekend was het existentialisme in Nederland?

3. Invloed van het existentialisme

4. Reactie op de oorlog?

5. De tweedeling van Delfgaauw

6. Hampton Court existentialistisch?

7. Relatie tot naturalisme, modernisme en personalisme

8. Operationalisering van de term 'existentialisme'

9. Relatie literatuur en filosofie

10. Besluit

II. Beschreven keuzes: voor en tegen [31]

1. Afbakening van het literaire existentialisme

2. Filosofische aspecten

3. Ethische en esthetische variant

4. Kenmerken

5. Pre-reflexiviteit en lichamelijkheid: Sartre versus Merleau-Ponty

6. Vervreemding of verzoening?

7. Absolute of geconditioneerde vrijheid?

8. Literaire technieken

9. Conclusie

III. Paspoort voor niemandsland

1. Inleiding

2. Vertelsituatie

3. Cursieve passages

- eerste groep

- tweede groep

- derde groep

4. Flashbacks en simultaneïteit

5. Ironie

6. Conclusie 
IV. Existentialistisch paspoort $1 \quad|61|$

1. Grenssituatie

2. De ander als katalysator

- de projecterende blik

- lichaamsbeleving

- niemandsland

V. Existentialistisch paspoort $2 \quad$ [85]

1. Engagement

- absurditeit of het existentiële misverstand

- de kwade trouw

- de authenticke buitenstaander

2. Gesloten ruimtes

3. Geseculariseerde invulling van christelijke begrippen

4. Classificatieprocédé

5. Registerwisselingen

6. Receptie van Paspoort voor niemandsland

7. Besluit

VI. Existentialisme en poëzie | 113$]$

1. Een zoektocht naar verwijzingen

2. Uitgangspunten

3. Het spiegelmotief

4. Gesloten ruimtes

5. Geseculariseerde invulling van christelijke begrippen

6. Lichaamsbeleving

7. Conclusie

VII. De abstracte Warmond

1. Inleiding

2. Mannelijkheidskritiek

3. Desillusie

4. Andere abstraheringstechnieken

5. Onthullende verhulling

6. Dunne enkels, vederlichte hand

7. Conçusie 
VIII. Poezzie en engagement

1. Inleiding

2. Sartre en de poëzie

3. Engagement in Nederland

4. De geëngageerde Warmond

5. Een stuipende pruik van gewichtigheid

6. Besluit

IX. Voor wie nit is op inkeer

1. Inleiding

2. Mystiek

3. De mijnschacht van de eigen geest

4. Zodat geen wimper meer fladdert

5. De vuile nagel der versterving

6. Hier ter plaatse

7. Conclusie

$X$. De berg in vogelvlucht

1. De berg in het westen

2. De berg in het oosten

3. Conclusie

XI. Everest/Himalaya

1. Hoger kan niemand komen

2. De steen der wijzen

3. Ziehier het nu

4. Ik gorgel met poëzie

5. De grote klokslag

6. Gehinderd door mijn bagage

7. Mystiek

XII. Eindconclusie [249]

XIII. Summary [253]

Lijst van geciteerde gedichten van Ellen Warmond |257]

Bibliografie $\quad[261]$

Curriculum vitae $\quad[275]$

Register van personen [ 277] 



\section{INLEIDING}

'Haal die zwarte coltrui en donkere zonnebril maar weer uit de kast, want het existentialisme is terug van weggeweest', aldus Rob Hartgers in Folia (maart 2002) in zijn recensie van Amélie Nothombs roman Cosmetica un de vijand. Omdat Nothomb het thema van de existentiële eenzaamheid minder zwaar op de hand presenteert dan Sartre noemt Hartgers de roman zelfs een vrolijke variant van het existentialisme.

Er is al enige tijd sprake van een hernieuwde belangstelling voor het existentialisme. In 1996 verscheen Bescheven keuzes, een studie van Hans van Stralen over het literaire existentialisme, waarin onder andere het werk van Anna Blaman besproken wordt. Het jaar daarop werd in het kader van een Studium Generale aan de universiteit van Utrecht een congres gehouden over het existentialisme. In dat jaar kwam er ook een Nederlandse vertaling uit van Fenomenologie wan de uxarneming (oorspronkelijk verschenen als Phénoménologie de la perception, Parijs 1945) van de existentieel fenomenoloog Merleau-Ponty. In 2002 verscheen er een vertaling van Enten-Eller $(O f / O f)$ van Sören Kierkegaard, een van de grondleggers van het existentialisme. Dit boek bevat een van de basisidecën van het existentialisme: leven is kiezen.

Niet alleen in Nederland, maar ook in. Amerika bestaat opnieuw interesse voor het existentialisme. Op literair gebied is er met name belangstelling voor Albert Camus. Ook op wetenschappelijk gebied is men geïnteresseerd. Zo verscheen enkele jaren geleden The Debate between Sartre and Merleau-Ponty (Evanston 1998), een bundel artikelen waarin de visies van de in de titel genoemde auteurs uitvoerig met elkaar vergeleken worden. Kort daarna werd een Dictionary of Existentialism gepubliceerd (Westport 1999), waarin op alfabetische volgorde artikelen staan over denkers, schrijvers, termen ẹn ideeën die in het existentialisme en de existentiële fenomenologie een rol spelen.

Existentiële onderwerpen als vrijheid, persoonlijke verantwoordelijkheid, politiek-maatschappelijk engagement, beleving van het lichaam, de verhouding tussen lichaam en geest, het omgaan met angst en vervreemding: het zijn onderwerpen die in onze tijd nog steeds (of weer?) actueel zijn.

Het zijn thema's die ook terug te vinden zijn in het werk van Ellen Warmond (Rotterdam 23 september 1930). In 1953 debuteerde Warmond met Proeftuin. Voor deze gedichtenbundel kreeg zij de Reina Prinsen Geerligsprijs, die zij overigens moest delen met Remco Campert. Daarna volgden nog, vele bundels. In 1961 werd haar de Jan Campertprijs toegekend voor de bundel Warmte, een woonplaats. In 1987 ontving zij voor haar gehele oeuvre de Anna Bijns Prijs voor Poëzie.

Diverse recensenten hebben erop gewezen dat de poëzie van Warmond een zekere affiniteit vertoont met het existentialisme. In haar studie Existential Thought and Fitional Technique (Londen 1970) bevestigt Edith Kern Sartres stelling, dat er een bepaald verband is tussen de levensvisie van een auteur en de literaire technicken 
die hij of zij gebruikt. Recensenten van Warmonds werk beperken zich echter meestal tot het aanstippen van enkele inhoudelijke overeenkomsten, zonder in te gaan op de daarmee verband houdende literaire vormgeving.

De doelstelling van mijn onderzoek is meerledig. Allereerst wil ik onderzoeken op welke wijze Warmonds affiniteit met existentialistische ideeën zowel inhoudelijk als formeel tot uiting komt in haar werk. Vervolgens wil ik nagaan wat Warmonds bijdrage aan het literaire existentialisme is. Ten slotte wil ik onderzoeken of enkele mystiek aandoende gedichten al dan niet een breuk impliceren in het oeuvre van Warmond.

Hoofdstuk I bevat een overzicht van verspreiding en populariteit van het existentialisme in Nederland. Ook komt de vraag aan de orde op welke manieren het literaire existentialisme tot nu toe werd gedefinieerd en afgebakend, zowel in de tijd als ten opzichte van een aantal stromingen. Hoe bestudeer je de relatie tussen literatuur en filosofie? De laatste paragraaf van dit hoofdstuk gaat hierop in.

In hoofdstuk II wordt Beschreven keuzes (Leuven/Apeldoorn 1996), een studie van Hans van Stralen over het literaire existentialisme, kritisch besproken. Verder bevat het hoofdstuk een vergelijking tussen enkele ideeën van Sartre en Merleau-Ponty. De existentiële fenomenologie van zowel Sartre als Merleau-Ponty zal als interpretatiekader dienen voor het werk van Warmond.

in hoofdstuk III-V staat Warmonds eerste en enige roman Paspoort voor niemandsland (1961) centraal. Dit boek krijgt relatief veel aandacht, omdat het zowel inhoudelijk als formeel Warmonds affiniteit met het literaire existentialisme laat zien. Bovendien bevat Paspoort voor niemandsland ideeën en uitspraken die Warmonds poëzie in een helderder licht kunnen plaatsen.

In het tweede deel van mijn boek (hoofdstuk VI-XI) komt Warmonds poëzie uitgebreid aan bod. Ik heb er vanwege de leesbaarheid voor gekozen om per hoofdstuk telkens één karakteristiek gedicht uitvoerig te analyseren. Over het algemeen bespreekt men in het kader van het literaire existentialisme alleen romans en toneelstukken. Hoofdstuk VI laat zien dat poëzie ten onrechte vaak buiten beschouwing wordt gelaten.

Een van de kenmerken van. Warmonds poëzie is de sekse-neutraliteit, dat wil zeggen dat je als lezer niet uit het gedicht kunt opmaken of het over een man of een vrouw gaat. Hoofdstuk VII gaat in op de vraag waarom Warmond hiervoor kiest en welk effect deze keuze heeft op de lezer.

Sluiten poëzie en politiek-maatschappelijk engagement elkaar uit, zoals Sartre suggereert? Welke rol speelt politiek engagement in de na-oorlogse Nederlandse poëzie en welke plaats neemt Warmond daarbij in? Deze vragen komen aan de orde in hoofdstuk VIII.

De laatste hoofdstukken gaan in op mystieke aspecten van enkele gedichten van Warmond. Vanwaar deze overgang van existentialisme naar mystiek? Sluiten mystiek en het aards gerichte existentialisme elkaar niet uit? Wat is mystiek en welke vorm van mystiek is in het werk van Warmond terug te vinden? Deze vragen 
staan centraal in hoofdstuk IX-XII. Het verlangen naar eenheid, het loskomen van tijd en ruimte en beelden voor het pre-verbale spelen in Warmonds poëzie een belangrijke rol. Een controlerend, reflexief bewustzijn kan een spontane, pre-reflexieve lichaamsbeleving belemmeren, maar wanneer het lyrisch subject daaraan kan ontsnappen maakt dualisme plaats voor een unificerende werkelijkheidservaring. Voor al deze elementen heb ik in de voorafgaande hoofdstukken de existentièle fenomenologie van met name Merleau-Ponty als interpretatiekader ingezet. Er zijn echter ook intrigerende overeenkomsten met mysticke concepten en mystiek vocabulaire. Vandaar dat de gedichten 'Voor wie uit is op inkeer' en 'Everest/Himalaya' vanuit een mystiek interpretatiekader geinterpreteerd worden. Deze benadering werpt een ander licht op Warmonds werk, met name op haar poëzie.

Het boek sluit af met eindconclusies en aanbevelingen voor verder onderzoek.

Graag wil ik mijn promotor Wiel Kusters en tweede promotor Maaike Meijer hartelijk danken voor de inspirerende en leerzame gesprekken, afwisselend in de Kapoenstraat en de Bouillonstraat te Maastricht.

Verder dank ik meelezer Jittine Oortman Gerlings-de Jong voor haar enthousiasme en accuratesse. Adri Holderbusch-Klaver was zo vriendelijk enkele vertaaladviezen te geven. Dave Mahoney ben ik dankbaar voor de deskundige vertaling van de samenvatting. Bovenal dank ik Maaike van der Lende, die altijd als eerste mijn stukken las. Aan haar draag ik dit boek op.

Trudy van Wijk

Bergen (NH) 



\section{NEDERLAND EN HET LITERAIRE EXISTENTIALISME}

\section{Een absurd probleem?}

In zijn artikel 'Existentialisme in de Nederlandse literatuur; een absund probleem?' vraagt Ton Anbeek zich af in hoeverre je de Nederlandse literatuur van na de oorlog existentialistisch kunt noemen. De term 'existentialisme' is volgens Anbeck inmiddels zo aan inflatie onderhevig, dat hij niet operationeel is. Het is dan ook lastig om ondubbelzinnig herkenbare existentialistische thema's in een literair werk aan te tonen. Voorzover die al aanwijsbaar zijn (wanhoop, eenzaamheid, morele keuze, het absurde) gaat het om onderwerpen die evengoed zonder Franse invloed in de Nederlandse roman terechtgekomen kunnen zijn. Bovendien gaat het vaak om existentiële keuzes die in elk kunstwerk met een humanitaire strekking voorkomen.

Anbeek heeft geen bezwaar tegen de term existentialisme, als er maar niet meteen gedacht wordt aan invloed van de Franse existentialisten, die volgens hem eind jaren vijftig nog maar nauwelijks bekend waren in Nederland. Het gaat om een gelijkwaardige reactie op de oorlog op internationaal niveau, zowel binnen als buiten de literatuur, waarbij hij niet uitsluit dat de Franse ideeën later wel tot een verscherpte formulering bij Nederlandse auteurs kunnen hebben geleid. Zijn studies $\mathrm{Na}$ de oorlog ${ }^{2}$ en Geschiedenis van de Nederlandse literatuur 1885-1985.3 bevatten in grote lijnen deze zelfde visie.

Anbeek doet overigens zelf geen poging tot een scherpere definitie te komen. In plaats daarvan volgt hij de tweedeling die Delfgaauw ${ }^{4}$ volgens hem aanbrengt in het werk van Sartre: enerzijds het existentialisme van eenzaamheid en wanhoop, anderzijds het existentialisme van de morele keuze, dat een latere fase in het werk van Sartre zou vertegenwoordigen.

Een voorbeeld van de laatste categorie is volgens Anbeek Vestdijks De kellner en de levenden (1949), waarin de duivel twaalf stervelingen voor het blok zet met de vraag: zijn ze bereid God en het bestaan te vervloeken? Er kan echter geen sprake zijn van Franse invloed, omdat het existentialisme van de keuze toen nog niet was uitgevonden door Sartre en Camus, aldus Anbeek.

Hij kent maar één voorbeeld van een existentialistisch aandoende roman van de eerste categorie: het in 1931 verschenen Hampton Court van Menno ter Braak. Anbeek ondersteunt zijn bewering slechts met twee citaten, waarin de nadruk ligt op de leegte, de zinloosheid of de contingentie van het bestaan, de walging, het hier op aarde 'geworpen' zijn en dingen die gehumaniseerd worden:

1 in: Literatuur. Utrecht 1984/1:4-8

2 Ton Anbeek, Na de oorlog. De Nederlandse roman 1945-1960. Amsterdam 1986

3 Ton Anbeek, Geschiedenis wan de Nederlandse lifenatuur 1885-1985. Amsterdam 1990²

4 B. Delfgaauw, Wat is existentialisme? Baarn 1948 
Een uur had hij. er gezeten; de sandwiches bleven als dwaze lichaampjes voor hem liggen, zo afzonderlijk als hij, ze nog nooit had gezien. Al die tijd was er maar één gedachte in hem, die redelijk tegen de leegte in hem streed: "Ik moet weg, weg naar de plaats, waar ik deze leegte het minst zal voelen [... $]^{\text {"5 }}$

Het feit dat Ter Braaks roman zeven jaar eerder verscheen dan La nausée (1938) toont volgens Anbeek aan dat er eerder sprake is van een gemeenschappelijk geestesklimaat dan van Franse invloed.

Diverse aspecten uit Anbeeks artikel nodigen uit tot een reactie: de mate van bekendheid van het existentialisme in Nederland in de jaren vijftig, invloed van het existentialisme op de naoorlogse Nederlandse roman, het existentialisme als reactie op de oorlog, de tweedeling van Delfgaauw, Hampton Court als existentialistisch aandoende roman en tenslotte de operationalisering van de term existentialisme.

\section{Hoe bekend was het existentialisme in Nederland?}

Anbeek beweert dat de Franse existentialisten eind jaren vijftig nog maar nauwelijks bekend waren in Nederland. Het aantal studies dat hij noemt ondergraaft echter zijn stelling: Existentiephilosophie en literatuurbeschouwing (1946) van S. Dresden, Wat is existentialisme? (1948) van Delfgaauw, Korte inleiding in de existentiephilosophie (1948) van Van Peursen, Existentialisme. Een doortocht door filosofisch grondgebied (1949) van Hans Redeker en een artikel in Criterium (1945-1946) van W.F. Hermans met de titel 'Stelt Nederland belang in Sartre?' In zijn studie Na de oorlog (1986) erkent Anbeek overigens dat Dresden het existentialisme grotere bekendheid gaf door zijn boek Existentiephilosophie en literatuurbeschouwing.

In feite was het existentialisme anderhalf jaar na de bevrijding al een mode in Nederland, overigens vooral onder filosofen en theologen. De Universiteit van Amsterdam had al in 1947 Bernard Delfgaauw aangesteld als privaatdocent in de existentiefilosofie. Bovendien verschenen er in de eerste jaren na de oorlog vele oraties, inleidingen en filosofische proefschriften over het existentialisme. ${ }^{7}$

Maar ook in literair opzicht staat het existentialisme in Nederland na de oorlog volop in de belangstelling. ${ }^{8}$ In september 1946 is er in het Kurhaus van Scheveningen voor het eerst een symposium over het existentialisme en aan het eind van dat jaar zijn Sartre en De Beauvoir uitgenodigd in Amsterdam, waar ze met diverse auteurs hebben gesproken. Met name Dresdens boek wordt in. zeker tien cultureel-literaire tijdschriften besproken, o.a. in Criterium, Elseviers weekblad, De gids,

5 Menno ter Brak,, Hampton Court. Amsterdam 1982: 17

6 W.F. Hermans, 'Stelt Nederland belang in Sartre?' Criterium 1945-1946/13, 713-715

7 zie S. Snreets, 'Over de receptie van het existentialisme in Nederland.' In: Studium. Generale reeks, Bureau Studium Generale, Universiteit Utrecht 1997: 113-133

8 zie: Frans Ruiter en Wilbert Smulders, Litenatuur en modemiteit in Nederland 1840-1990. Amsterdam 1996: 272 
Roeping en Vrij Nederland. Ook Vanheste (1992) ${ }^{9}$ vermeldt dat er in de jaren 1945-1946 in Nederland en Vlaanderen tientallen artikelen verschenen over de geschriften van Sartre en Camus. Calis toont in zijn studie over schrijvers en tijdschriften tussen 1945 en $1948^{10}$ aan, dat diverse tijdschriftjes aandacht besteedden aan het Franse existentialisme.

Anbeek laat ten onrechte de poëzie buiten beschouwing. In zijn studie over de poëzie van Gerrit Kouwenaar wijst Kusters op existentialistische sporen in de gedichtencyclus 'weg/verdwenen' uit 1961. " Naast onderzoekers erkennen ook diverse literaire auteurs, onder wie enkele dichters, de invloed van het existentialisme. In Hofland/Rooduijn 1997 geven Campert, Claus, Kouwenaar, Schierbeek en Kousbroek aan dat ze in de jaren vijftig bekend waren met het werk van Sartre en Camus. Campert:

We lazen Sartre, Camus, maar de Franse poëzie veel minder. [... | Ik kleedde me als existentialist: zwarte truien, lange broeken met korte pijpen. Je ging als een wat treurige schim door de stad. [...] Die modieuze aspecten van het existentialisme zijn dus niet aan mij voorbijgegaan. Maar een groot filosoof ben ik nooit geworden. ${ }^{12}$

Claus heeft Sartre vaak gezien in Parijs en las Les temps modernes in de jaren rond 1950. Kousbroek noemt als bepalende factor in zijn vorming zijn discussies met Franse studenten:

We waren toen allemaal-ikzelf zeker ook- aanhangers van het existentialisme en worstelden met schijnproblemen. Zelfs als je de vroege werken van Hermans leest, is die invloed te merken. In de eerste drukken, want hij heeft daar later ẹn heleboel van uitgehaald om de fictie vol te kunnen houden dat hij altijd al een Wittgenstein-aanhanger was. Maar dat was aanvankelijk niet zo, in een boek als Conserve is dat duidelijk te zien. ${ }^{13}$

Vanaf 1947 voerde men regelmatig existentialistische toneelstukken op, overigens eerst in studentenkringen. ${ }^{14}$ Het jaar daarop speelde het professionele toneel twee toneelstukken van Sartre: Huis clos in Rotterdam en Morts sans sépulture in Amsterdam. De verfilming van Les jeux sont faits van Sartre (onder de Nederlandse titel. De weg zonder einde) had in 1948 in Nederland echter minder succes dan zijn

9 Bert Vanheste, 'Existentialistische literatuur. Een absurd probleem of een niet zo zinvolle oplossing?' Literatuar 1992, afl. 3, p. 144-150

10 Piet Calis, Speeltuin un de titaantjes. Schrijvers en tijdschriften tussen 1945 en 1948. Amsterdam 1993

11 zie Wiel Kusters, De killex. Over poézie en poètica san Gerrit Konwenaar. Amsterdam 1986: 179 e.v.

12 H.J.A. Hofland en Tom Rooduijn, Duvars door puinstof heen. Grondlegeers van de naoorlogse literatuur. Met documentaire over de Vijftigers op cd. z.p. 1997:50

13 Hofland/Rooduijn 1997: 52

14 gespeeld werden Les mouches en Huis dos. Deze informatie is ontleend aan S. Smeets 1997: 122 
toneelwerk. ${ }^{15}$ Anna Blaman vertaalde diverse werken van Sartre, onder andere diens toneelstuk Les mains sales, dat in 1950 in première ging bij het Rotterdams toneel, en Les mouches, dat in 1953-1954 op het programma van de Rotterdamse Comedie stond, waar Blaman inmiddels als dramaturge aan was verbonden (het stuk werd echter niet opgevoerd). Bovendien hield ze lezingen over het werk van Camus. ${ }^{16}$

Niet alleen Sartre, maar ook Camus werd gespeeld. In 1951 vond de Nederlandse première van Caligula plaats, dat drie jaar eerder hier al opgevoerd was door een Frans toneelgezelschap. Ook andere stukken van Camus, zoals Les justes en $L$ e malentendu, werden regelmatig opgevoerd.

De receptie van het werk van Simone de Beauvoir verliep enigszins anders. Haarstudie Le deuxième sexe uit 1949 werd uitgebreid besproken, onder andere door Annie Romein-Verschoor. Deze recensent schreef een overwegend positieve bespreking, alleen plaatste ze een kanttekening bij het absolute vrijheidsconcept van De Beauvoir. De Franse filosofe slaat volgens haar op hol

wanneer zij zonder enig redelijk bewijs overigens, betoogt, dat het ook een 'keuze' is, die de hetero-sexuele of homo-sexuele gesteldheid van de mens en als ik het goed begrepen heb, speciaal van de vrouw bepaalt. ${ }^{17}$

Het literaire werk van Simone de Beauvoir kreeg in ons land pas later meer aandacht, nadat haar voor Les mandarins (1954) de Prix Goncourt was toegekend. Kortom, het existentialisme was eind jaren ' 40 , begin '50 in Nederlandse literaire kringen wel degelijk bekend. De plaatsing op de Index van het Vaticaan van alle werken van Sartre en enige tijd later ook van De Beauvoir zal ongetwijfeld hun succes vergroot hebben.

15 de toneelgegevens zijn ontleend aan S. Smeets 1997: 122-124

$16 \mathrm{H}$. Struyker Boudier, Speurtocht naar een onbekende. Anna Blaman en haar Eenzaam avontuar. Amstendam $1978^{2}: 84-86$

17 in: Annie Romein-Verschoor, Spelen met de tijd. Nijmegen 1979:221 (oorspronkelijk verschenen in De Nicuue Stem 5, 1950, p. 516-520). 


\section{Invloed van het existentialisme}

Anbeek relativeert de invloed van het existentialisme op de naoorlogse Nederlandse roman. Verschillende onderzoekers wijzen ook nog op andere invloeden. Naast grote belangstelling voor het werk van Sartre en Camus, die op hun beurt weer beïnvloed werden door Voyage au bout de la muit (1932) van Louis-Ferdinand Céline (1894-1961) ${ }^{18}$, was er ook interesse voor Amerikaanse ${ }^{19}$ en Engelse literatuur ${ }^{20}$. Met name auteurs als Faulkner, Koestler, Hemingway en Graham Greene werden veel gelezen. Rodenko echter stelt dat Sartre, die weliswaar zelf geen gedichten heeft geschreven, veel invloed heeft gehad op de hedendaagse poëzie. ${ }^{21}$ Hij ironiseert overigens enigzzins de bekendheid van Sartres studie L'être et le néant (1943), omdat vooral Franse zuigelingen hadden bijgedragen aan het succes van dit boek. De eerste druk van Sartres boek woog namelijk precies één kilo:

Daar er toentertijd (1943) een groot gebrek aan gewichten heerste, vond het boek een gerede aftrek bij moeders, die het gebruikten om hun zuigelingen te wegen; er waren er zelfs die in de boekhandel vijf of zes Etre-et-néants tegelijk vroegen, zodat men de verkoop weldra moest rantsoeneren [...] Toen het boek zo vlot bleek te gaan, gingen dan ook blijkbaar mensen, die zich anders niet aan zu th ulk'k' pu'gewaga' inadeen, het lezen (net wetende wat de oorzaak van de vlotte verkoop wel was) - en zo hielpen de Franse zuigelingen het existentialisme op de troon $[\ldots]^{22}$

De absurditeitsgedachte kwam niet bij Faulkner maar bij de Russische literatoren voor het eerst scherp naar voren. Maac omdat de Russische literatuur altijd buiten de westerse traditie heeft gestaan, heeft zij niet meer dan een zijdelingse invloed uitgeoefend. Alleen dat wat in de 'Europese cultuurkraam' te pas kwam, werd overgenomen, aldus Rodenko. Hij noemt Kelder-Mémoires ${ }^{23}$ van Dostojevski (1821-1881) vanwege het thema van de stroperigheid (viscosité) een door en door existentialistische novelle, die evengoed door Sartre geschreven zou kunnen zijn. Rodenko zou ook existentialistische tendensen aan kunnen tonen bij schrijvers als Gogol en Tsjechov. Maar ook hun ideeën vonden toentertijd geen voedingsbodem in West-Europa. Pas in het Franse existentialisme komt het thema van de viscosité weer naar voren. ${ }^{24}$

18 Piet Calis, F.P. Huygens, B. W.E. Veurman, Het spel en de knikkers. Kernboek 2. Amsterdam 1975: 246 19 Kees Schuyt, Ed Taverne, 1950 Welyart in zuart-wit. Nederlandse cultuut in Europese context deel IV. Den Haag 2000: 440-441

20 Piet Calis, Speeltuin van de titaanties. Schrijvers en tijdschriften tussen 1945 en

1948. Amsterdam 1993: 20

21 Paul Rodenko, Verzamelde essays en kniticken. Deel 2. Amsterdam 1991, p. 375

22 Paul Rodenko, Verzamelde essays en kriticken. Deel 3. Amsterdam 1992, p. 84

23 ook bekend onder de titels Aantekeningen wit het ondergrondse en De man uit het souternain

24 Paul Rodenko, Vazamelde cssays en kritieken. Deel 1. Amsterdam 1991, p. 373. 


\section{Reactie op de oorlog?}

Anbeek stelt, dat veel van wat men 'existentialistisch' noemt met meer recht 'naoorlogs' zou mogen heten:

In Frankrijk uitte de naoorlogse desillusie zich op een bepaalde, sterk geprononceerde manier. Maar ook Nederland blijkt na 1945, als de bevrijdingsroes is uitgewoed, bepaald geen vrolijk land: economische malaise, het idee dat met het verlies van Indië de rampspoed was geboren, en vooral de voortdurende dreiging van een nieuwe wereldoorlog beperken het bestaan. Daarop doelt Van het Reve als hij zegt dat De avonden óók 'die rare onstabiele situatie met die blaséheid' weergeeft. Mijn conclusie is kortgezegd, dat het niet zinnig is deze autochtone somberheid met de zozeer naar de Franse situatie verwijzende term 'existentialistisch' aan te duiden. ${ }^{25}$

Het is de vraag of De avonden inderdaad exemplarisch is voor de manier waarop men in Nederland reageerde op de naweeën van de oorlog. Ten eerste gaat Anbeek voorbij aan het maatschappelijk engagement van de Vijftigers, die zich verzetten tegen de restauratieve tendens en de ideologische en politieke blokvorming van die tijd. De Vijftigers vormden weliswaar geen politieke protestbeweging, maar in hun vernieuwende poëzie verwoordden ze ook gevoelens van onvrede met de maatschappelijke ontwikkeling en van verlangen naar verandering daarin rond 1950. Cobra en zijn voorganger Reflex zijn eind jaren veertig de organen van een internationale beweging van kunstenaars die een artistieke vernieuwing nastreefden in samenhang met een maatschappelijke verandering. In Reflex 2 verscheen Luceberts Minnebrief aan onze gemartelde bruid Indonesia, waarin hij zich scherp afzet tegen het zogenaamd vredige Nederland. ${ }^{26}$ Die 'autochtone somberheid' is dus niet zo algemeen als Anbeek ons wil doen geloven.

Ten tweede werden niet boeken als L'étranger en La nausée als eerste vertaald, zoals men zou verwachten. Vertalingen daarvan verschenen pas respectievelijk in 1949 en in 1950. De eerste vertaalde existentialistische teksten waren teksten die allemaal samenhingen met de oorlog. In 1946 verscheen een vertaling van Camus' Brieven aan een Duitse vriend, een aanklacht tegen het nationaal-socialisme. Het jaar daarop kwamen vertalingen uit van Camus' Noch beul, noch slachtoffer, een verzameling artikelen uit de verzetskrant Combat, waarvan Camus hoofdredacteur was, en van Sartres Portret van een antisemiet. Overdenkingen over het joodse vraagstuk. In 1948 kwam van Camus De pest uit, dat ook in Nederland gelezen werd als een metafoor van de oorlog. In datzelfde jaar verscheen van Sartre Doden zonder graf, waarin een verzets-

25 Ton Anbeek 'Existentialisme in de Nederlandse literatuur: een absurd probleem?' Litentuur, Utrecht $1984: 8$

26 Harry Scholten, 'Lyriek is de moeder der politiek. Opvattingen over poëzie en maatschappelijk engagement in de dichtersbeweging der Vijftigers.' Litenatuur, Utrecht 1984, p. 13-18 
groep zich afvraagt of men tijdens martelingen stand zal kunnen houden. ${ }^{27}$ Blijkbaar was er in het naoorlogse Nederland voldoende belangstelling voor deze geëngageerde teksten.

Anbeeks voorstel de term 'existentialistisch' in te ruilen voor de term 'naoorlogs' wordt nergens goed onderbouwd. De term 'naoorlogs' roept nogal wat vragen op: is die term van toepassing op alle literatuur uit de jaren ' 40 en '50 of alleen op een bepaalde categorie? Zo ja, hoe onderscheidt deze categorie zich inhoudelijk en formeel ten opzichte van andere categorieën? Ook over de periodisering zegt Anbeek niets. Kortom, de aanduiding 'naoorlogs' is minstens zo vaag als het door hem gebruikte begrip 'existentialistisch'.

Bovendien is Anbeek niet erg consistent. In zijn studie uit 1986 noemt hij een roman alleen existentialistisch als het probleem expliciet in existentic-filosofische termen wordt verwoord, zoals in Grensconflict (1948) van Sierksma. ${ }^{28}$ Anbeek $1990^{2}$ is echter minder stellig: er is niets op tegen om het ontluisterend naoorlogs proza existentialistisch te noemen, zolang er geen directe relatie tussen het werk van Sartre en Camus enerzijds en dat van Hermans, Blaman en Reve anderzijds wordt gesuggereerd. Het gaat om een gelijkwaardige internationale reactie op de oorlog.

\section{De tweedeling van Delfgaauw}

In de literaire bladen wordt vooral naar Sartre verwezen. Dat is voor Anbeek een reden om bij zijn speurtocht naar existentialisme in de Nederlandse literatuur uit te gaan van de tweedeling die Delfgaauw volgens hem in het werk van Sartre aanbrengt: het existentialisme van eenzaamheid en wanhoop enerzijds en het existentialisme van de morele keuze (het 'zich kiezen') anderzijds. In Wat is existentialisme. ${ }^{29}$ verwoordt Delfgaauw het anders. Sartre stelt in al zijn werken de mens centraal. In de eerste periode valt echter alle nadruk op de eenzaamheid van de mens, terwijl in de tweede periode de verbondenheid van de mensen onderling meer naar voren komt. De eerste twee delen van de romancyclus Les chemins de la liberte $^{30}$ vormen volgens Delfgaauw de overgang. Het betreft dus eerder accentverschillen en een geleidelijke overgang dan een scherpe scheiding.

Twee eeuwen literatuurgeschiedenis (Groningen 1986) van G.J. van Bork en N. Laan neemt Anbeeks visie zonder meer over. De tweede vorm, het existentialisme van de morele keuze, is volgens Anbeek van later datum. Vanheste toont aan, dat dat uitgangspunt niet juist is. ${ }^{31}$ In september 1944 legt Sartre in het communistische

27 gegevens ontleend aan S. Smeets 1997: 124-128

28 in: Na de oorlog. De Nederlandse roman 1945-1960. Amsterdam 1986: 102

29 B. Delfgaauw, Wat is existentialisme? Baarn 1966 (zesde herziene druk): 105

30. Les chemins de la liberté bestaat uit drie delen: L'dge de maison (1945), Le sursis (1945) en. La mort dans l'ame (1949). In Nederland kwamen de delen uit in de vertaling van Maurits Mok als De jaren des onderscheids (1949). Het oponthoud (1952) en De dood in het hart (1952). Het vierde deel, dat La dermiere chance zou gaan heten, is nooit voltooid.

31 Bert Vanheste, 'Existentialistische literatuur. Een absurd probleem of een niet zo zinvolle oplosing?' Literatuar 1992, afl. 3, p. 144-150 
weekblad Action al de nadruk op de vrijheid en de verantwoordelijkheid van de mens. In het beeld van het Franse existentialisme dat uit Nederlandse en Vlaamse publicaties naar voren komt, nemen vrijheid en verantwoordelijkheid, morele keuze, het ethische en zelfs het politieke engagement een belangrijke, zo niet centrale plaats in, aldus Vanheste. Misschien is er hooguit sprake van een accentverschil. Vanaf Le mythe de Sisyphe (1942) vind je ook bij Camus de vrije keuze terug. Hans van Stralen signaleert twee andere lijnen in het literair existentialisme: de ethische variant, gerepresenteerd door Sartre, en de esthetische variant, vertegenwoordigd door Camus. ${ }^{32}$ In hoofdstuk II daarover meer.

\section{Hampton Court existentialistisch?}

Anbeek is niet de enige en zeker niet de eerste die in Ter Braaks roman Hampton Court existentialistische trekken ontdekt. De in 1976 overleden Paul Rodenko noemde in zijn 'Brief aan een kritische vriend' het eerste deel van Hampton Court zuiver existentialistisch. ${ }^{33}$ Ook hij wijst op de treffende overeenkomsten met La nausée. De door hem uitgekozen citaten overlappen voor een deel die van Anbeek, die er overigens geen blijk van geeft het stuk van Rodenko te kennen. Volgens Rodenko zouden we ze 'gemakkelijk voor passages uit een in het Nederlands vertaald werk van Sartre kunnen houden.' Rodenko wijst naast de vervreemding ook nog op een ander existentialistisch thema: de stroperigheid van het en-soi (het zijnde) waarin de vrijheid van het handelend subject telkens opnieuw vastloopt. Herhaaldelijk terugkerende termen als vlezig, wellustig, vet, dik en olieachtig wijzen op de viscositeit van het en-soi. Ook de massa en de belemmering die daarvan uitgaat worden geassocieerd met termen uit de sfeer van het vette, zoals slaolie en wolligheid.

Als onderdeel van de walging ontstaat er een personificatieproces van de dingen, zoals bleek uit het voorbeeld van de sandwiches die opeens op lichaampjes leken. Een tegenhanger daarvan is de dehumanisering van personen, een motief dat zowel door Rodenko als door Anbeek niet expliciet genoemd wordt. In La nausée vergelijkt Roquentin zijn bestaan met dat van een steen, een plant of een microbe en zelfs een keer met een krab:

Ze dachten dat ik een mens was, iemand als zij, en ik heb ze bedrogen. Opeens viel mijn menselijke gedaante van me af en ze zagen een krab die achteruitlopend wegvluchtte $[\ldots] \cdot{ }^{34}$

In Hampton Court worden voorbijgangers door middel van de aquariummetafoor gedehumaniseerd als de hoofdpersoon voor de spiegelruit van een bodega zit:

32 Hans van, Stralen, Beschreven keuzes. Een inleiding in het litenaire existentialisme. Leuven-Apeldoorn 1996: $55-57$

33. Paul Rodenko, Verzamelde essays en knitieken. Deel 1. Amsterdam. 1991: 445 e.v.

34 Jean-Paul Sartre, Walging. Amsterdam $1990^{11:} 172$ 
Hij had toen ineens verzonnen: ik zit hier voor de ruit van het aquarium; de wonderlijkste diepzeevissen zwemmen aan mij voorbij [...]; er schieten ook trage, schele schollen tussendoor, ordinaire haringen, weke kwallen, spichtige witvisjes en vooral veel schildpad-ooms, tot barstens toe opgeblazen van gewichtigheid en ouderdomservaring, kandidaten voor een stevige beroerte. Maar hoe prachtig doen zij het allemaal in dat heldere luchtwater [...] (p. 136)

Anbeek proeft in Hampton Court wel Sartriaanse sensaties, maar hij vindt het geen existentialistische roman. Het is niet duidelijk op basis waarvan hij tot deze conclusie komt. Vanheste wijst er mijns inziens terecht op, dat Anbeek het existentialisme verengt tot datgene wat schatplichtig is aan Sartre. Vanheste definieert het existentialisme als een 'kentaurische' wereldbeschouwing, omdat hierin twee schijnbaar tegenstrijdige inzichten met elkaar verenigd worden: de opvatting dat het bestaan absurd is gaat samen met het besef dat de mens vrij en verantwoordelijk is. Pas als deze beide polen in een werk voorkomen kan een literair werk existentialistisch genoemd worden. Volgens Vanheste valt de roman van Menno ter Braak onder zijn definitie van existentialisme, hoewel hij dat verder niet in zijn artikel uitwerkt. In paragraaf $8 \mathrm{kom}$ ik terug op zijn voorstel om het begrip 'existentialisme' operationeel te maken voor de interpretatie van literatuur.

Ontegenzeglijk heeft Hampton Court inhoudelijk gezien opvallend veel existentialistisch aandoende trekken: de leegte-ervaring in de tuin van Hampton Court, het gevoel in een wereld geworpen te zijn die als absurd wordt ervaren, walging. vervreemding en depersonalisatie. Ook op het formele vlak zijn er overeenkomsten: het boek heeft zowel kenmerken van een roman als van een allegorie, er is sprake van programmatische namen en er zijn bepaalde fictionele technieken die het vervreemdingsmotief versterken.

Hampton Court heeft allegorische trekken, aangezien sommige personages bepaalde keuzes of posities vertegenwoordigen. Voorbeelden van dit classificatieprocédé zijn Andreas Laans vriendin Maffie, die de 'losbandige' sexualiteit representeert en Laan zelf, die het prototype is van de intellectueel die denkconstructies verkiest boven deelname aan het werkelijke leven. De namen van deze twee personages zijn ook op te vatten als programmatische namen. Maffie is afgeleid van 'maffen", haar naam geeft aan dat ze met iedereen slaapt. De achternaam van Andreas - Laan- verwijst al vooruit naar de uiteindelijke aanpassing van de hoofdfiguur. In plaats van avontuurlijke wegen te volgen kiest hij voor de gebaande paden, om niet te zeggen de keurig aangelegde lanen, van de conventionaliteit. ${ }^{35}$ Verder valt het op, dat het verschil tussen externe verteller en focalisator (Andreas) niet altijd even duidelijk is, omdat er een grote afstand bestaat tussen Andreas en de door hem beleefde werkelijkheid.

35. ook de naam van Van Haaften, Andreas' vriend, is op te vatten als een programmatische naam. Zijn naam zou samenhangen met het Duitse 'verhaften': hij heeft over alles en iedereen een negatief oordeel. Zie: Dina van. Berlaer-Hellemans, 'Twee romans uit de Forum-tijd: Hampton Court en Het land van herkomst. Deel 1: Hampton Court.' In: Spiegel der Letteren, 1978, jargang 20, nr. 4, p. 241-256 
Deze fictionele techniek versterkt het vervreemdingsproces waarin de hoofdfiguur zich bevindt. ${ }^{36}$

Hoewel er zowel inhoudelijk als formeel overeenkomsten zijn met het literaire existentialisme, heb ik toch nog enkele aarzelingen. Walging en absurditeit spelen slechts een incidentele rol in het boek, en dan nog vooral in het eerste gedeelte. Uieindelijk kiest de hoofdpersoon voor aanpassing als strategie om te overleven in een door hem als absurd ervaren wereld, hoewel hij beseft dat dit een teken van inauthenticiteit is ${ }^{37}$ Het is juist deze aanpassingsstrategie die conflicteert met het streven naar authenticiteit, dat in het existentialisme zo'n belangrijke plaats inneemt. In plaats van de vrijheid als opdracht te aanvaarden, kiest de hoofdpersoon bewust voor de conventionaliteit. Dit alles overdenkende concludeer ik, dat Hampton Court geen exponent van het literaire existentialisme is, maar wel een interessante voorloper daarvan.

\section{Relatie tot naturalisme, modernisme en personalisme}

Alvorens te komen tot een werkbare definitie lijkt het me belangrijk het existentialisme eerst af te bakenen ten opzichte van stromingen waarmee het enige overeenkomsten vertoont: het naturalisme, het modernisme en het personalisme.

In zijn Handboek tot de moderne Nederlandse letterkunde noemt G. Knuvelder de volgende kenmerken van het existentialisme: het leven is een duister avontuur, raadselachtig en zinloos. De nietige mens doolt verlaten en verloren rond op deze planeet, gefolterd door ondraaglijke angsten. Volgens Anbeek is de omschrijving van Knuvelder zonder meer van toepassing op grote delen van het Nederlands naturalisme. ${ }^{38}$ Deze constatering verbaast me, omdat de hoofdkenmerken van het naturalisme -de erfelijkheidsthese, de woordkunst en de determinierende invloeden van opvoeding en milieu- in deze vergelijking ontbreken. Knuvelders kwalificatie is niet zozeer weinig operationeel omdat zijn omschrijving punten van overeenkomst bevat met het naturalisme, maar, zoals Anbeek terecht opmerkt, omdat de Westeuropese literatuur sinds het midden van de negentiende eeuw overbevolkt is met verloren ronddolende helden en heldinnen.

Het literaire existentialisme begint rond 1935 als modernisten en avant-gardisten een minder prominente rol gaan spelen en Europa aan de vooravond van de Tweede Wereldoorlog staat. In temporele zin overlappen modernisme en literair

36 Van Berlaer-Hellemans 1978 is de enige auteur die niet alleen inhoudelijke aspecten mar ook enkele fictionele technieken in Hampton Court bespreekt, overigens zonder ze in een existentialistische context te plaatsen.

37 omdat de hoofdpersoon uiteindelijk kiest voor anpassing als overlevingsstrategie plaatst Léon Hanssen, de biograaf van Ter Braak, Hampton Court binnen de Nieuwe Zakelijkheid. Het boek beschrifft de mimicry-mentaliteit van de Nederlandse burger in het begin van de dertiger jaren als een poging om de traumatische ervaringen van de Eerste Wereldoorlog en de daarop volgende crisisjaren te boven te komen. In die situatie was aanpassing een vereiste, wilde je niet uit de boot vallen, aldus Hanssen.

38 zie: Ton Anbeek, Na de oorlog. De Nederlandse noman 1945-1960. Amsterdam 1986: 96 
existentialisme elkaar enigszins: de hoogtijdagen van het modernisme liggen in de periode 1910-1940, het literaire existentialisme begint rond 1935 en eindigt rond 1960 als de roman nouveau een dominante positie in de Franse literatuur gaat innemen.

In 'Postmoderne modernisten en modernistische postmodernen' (2001) ${ }^{39}$ stelt Jaap Goedegebuure, die Van Stralens studie over het literaire existentialisme overigens niet noemt, dat existentialisme en modernisme verenigbaar zijn. In zijn romancyclus Les chemins de la liberté maakt Sartre gebruik van modernistische vertelprocédés als stream of consciousness, simultaneiteit en montage. Zowel modernisten als existentialisten gaan uit van het individu als maat van alle dingen.

Toch is het mogelijk modernisme en literair existentialisme ten opzichte van elkaar af te grenzen. ${ }^{+0}$ In een modernistische roman zijn observatie, zelfonderzoek en reflexiviteit dragende elementen. Vandaar de voorkeur voor dagboek, essay en herinneringsroman, waarin met name de monologue intérieur een belangrijke plaats inneemt. Mede onder invloed van de Eerste Wereldoorlog brokkelt het vertrouwen in ideologieën af en dit leidt tot een zekere onthechting: het afwijzen van allerlei -illusoir gebleken- waarheidsclaims. De romanpersonages zijn niet of nauwelijks geëngageerd; als ze handelen is er eerder sprake van impulsiviteit dan van een wel overwogen keuze.

In een literair-existentialistische roman is de keuzeproblematiek een belangrijk thema: onder druk van de omstandigheden wordt het romanpersonage gedwongen tot een geëngageerde keuze, zoals in La Peste van Camus en Les mains sales van Sartre. Onthechting wordt beschouwd als een wereldvreemde houding, de personages moeten -of ze willen of niet- in ethische kwesties hun standpunt bepalen. Vaak wordt een romanfiguur in een beperkt gebied of afgebakende ruimte geplaatst, zoals een gevangenis, bordeel of de hel, omdat de romanfiguur in die situaties gedwongen wordt tot een positiebepaling.

In tegenstelling tot het modernisme, waarin zelfonderzoek een middel is om zichzelf te begrijpen, gat het literair-existentialisme ervan uit, dat alleen de ánder hẹt bewustzijn van zijn medemens duidelijk kan zien in zijn gezichtsuitdrukkingen en in zijn handelen. Vandaar de voorkeur voor proza en drama waarin veel plaats is voor dialogen.

Ruiter en Smulders wijzen op enige verwantschap tussen het existentialisme en het personalisme, aangezien beide na de oorlog volop in de belangstelling stonden in Nederland ${ }^{41}$ Het personalisme vormt een belangrijke ideologische schakel tussen de jaren dertig en de jaren zestig. Het zet zich af tegen levensbeschouwelijk nihi-

39 Jaap Goedegebuure, 'Postmoderne modernisten en modernistische postmodernen. Nederlandstalige schrijvers van de twintigste eeuw herlezen.' In: Nederlandse Letterkunde, jg. 6, nr. 1 januari 2001: 13-32.

40 zie: Hans van Stralen, Beschreven keuzes. Een inleiding in het litenaire existentialisme. Leuven-Apeldoorn 1996: 43 e.v.

41 zie: Frans Ruiter en Wilbert Smulders, Litenatuur en moderniteit in Nederland 1840-1990. Amsterdam 1996: 273 
lisme en materialisme. De personalistische gemeenschapsgedachte benadrukt persoonlijke ontplooiing, mondigheid en verantwoordelijkheid. De personalisten, zich realiserend dat terugkeer naar traditionele kaders niet meer mogelijk is, willen de samenleving radicaal veranderen. Ze keren zich echter tegen het existentialisme van Sartre c.s., ze voelen eerder verwantschap met de christelijke variant van het existentialisme van Kierkegaard, Jaspers en Gabriel Marcel. Het personalisme wordt ook wel eens een 'zachte' variant van het existentialisme genoemd. ${ }^{42}$

\section{Operationalisering van de term 'existentialisme'}

Anbeeks tweedeling -existentialisme van eenzaamheid en wanhoop aan de ene kant en existentialisme van de morele keuze aan de andere kant- bleek niet houdbaar te zijn. Bovendien is zijn inhoudelijke specificering van beide vormen zo vaag, dat ze op vrijwel de hele moderne wereldliteratuur van toepassing is.

Vanheste 1992 benadrukt dat het existentialisme een 'kentaurische' wereldbeschouwing is, namelijk een paradoxale combinatie van twee inzichten: het bestaan is absurd én de mens is vrij en verantwoordelijk. Existentialistisch zijn alleen die literaire werken waarin de absurditeit en de verantwoordelijkheid 'twee, continu onder hoogspanning staande, polen vormen van een even ondeelbare als paradoxale visie.' Het begrip existentialisme is pas operationeel te maken als beide polen erin voorkomen. Het voorstel van Vanheste, grotendeels gebaseerd op S. Dresden. 1946, luidt als volgt:

De in de wereld geworpen concrete mens, het tot de eenzaamheid en de dood veroordeelde individu, ontkomt vroeg of lat niet aan de ontdekking van het Niets, van de afwezigheid van een objectieve waarheid, van het ontbreken van enige buiten hemzelf of in hemzelf voorafgegeven $\mathrm{Zin}$. Gesteld voor de noodzakelijkheid de leegte waarvan hij walgt te vullen, zijn verantwoordelijkheid op te nemen, wordt hij overvallen door wanhoop en angst. Hij kan daarvoor op de vlucht slaan, zichzelf verraden door de lichamelijke zelfmoord of door de geestelijke vlucht in een religieus of maatschappelijk geloof, in een conventioneel leven. Hij kan ook moedig ervoor kiezen zijn vrijheid te aanvaarden, zich te verzetten tegen het lege en leugenachtige leven, het concrete, betrekkelijke bestaan te accepteren en er gelukkig mee te zijn, vorm te geven aan een subjectieve waarheid en ethiek, zich hier. en nu te engageren, in solidariteit met de ander zichzelf en de samenleving in voorlopigheid te maken. ${ }^{43}$

42 bijvoorbeeld in Van Stralen 1996: 72

43 Bert Vanheste, 'Existentialistische literatuur. Een absurd probleem of een niet zo zinvolle oplossing?'

In: Litenatuar 1992, afl. 3, p. 144-150 
Als een literair werk al deze wezenlijke kenmerken bevat, is het existentialistisch te noemen. In andere gevallen zal blijken dat existentialistische opvattingen een amalgaam vormen met bijvoorbeeld naturalistische of dieptepsychologische elementen. Hoewel dit een interessant voorstel is, geef ik de voorkeur aan de benadering van Van Stralen 1996. Het volgende hoofdstuk gaat uitvoerig in op zijn ideeën en voorstellen. Vanheste benadert het existentialisme als een filosofische stroming, waarvan denkbeelden in meerdere of mindere mate neergeslagen kunnen zijn in een literair werk. Van Stralen daarentegen maakt een onderscheid tussen filosofisch en literair existentialisme, waarbij hij bovendien oog heeft voor de autonomie van de literatuur.

\section{Relatie literatuur en filosofie}

Niemand zal ontkennen dat de interpretatie van bepaalde literaire werken verdiept kan worden door gebruik te maken van filosofische noties. De verhouding tussen literatuur en filosofie is echter niet onproblematisch. In postmoderne opvattingen gaat men er zelfs van uit dat er weinig verschillen bestaan tussen literatuur en filosofie in het algemeen, aangezien de filosoof, de romancier/essayist en de dichter ieder op talige wijze een persoonlijke visie op de wereld presenteren. Een verteld verhaal kan een even diepzinnige visie op de wereld geven als een filosofische verhandeling. Fictie is in zekere zin ook metafictie, omdat fictionele teksten tevens beschouwingen zijn over de zogenaamde realiteit. Andersom maken disciplines als de filosofie gebruik van narratieve, literaire procédés. ${ }^{44}$ Zowel Nietzsche als Kierkegaard bijvoorbeeld maakten gebruik van literaire technieken. Kierkegaard vond literaire vormen adequater om de rijke ervaring van individuen tijdens het pijnlijke proces van 'zelfontwerp' te beschrijven. Zijn boek Of/Of bevat een aantal stukken in de ik-vorm, geschreven door vier fictieve, onder pseudoniem schrijvende auteurs. In Also sprach Zarathustra maakt Nietzsche gebruik van literaire vormen en in veel van zijn werken hanteert hij een aforistische stijl. ${ }^{45}$

In een interview uit 1977 wijst de Britse auteur/filosoof Iris Murdoch op overeenkomsten en verschillen tussen literatuur en filosofie:

$[\ldots]$ philosophy and literature are both truth-seeking and truth-revealing activities. They are cognitive activities, explanations. Literature, like other arts, involves exploration, classification, discrimination, organised vision. Of course good literature does not look like 'analysis' because what the imagination produces is sensuous, fused, reified, mysterious, ambiguous, particular. Art is

44 zie Bert Vervaeck, 'Essay en vertelling in postmoderne tijden.' In: Nederlandse letterkunde, jargang 6. ni. 4, november 2001: 289-309

45 zie Jana Sawicki, 'Literature.' In: Haim Gordon, Dictionary of Existentialism. Westport 1999: 269-273 
cognition in another mode. Think how much thought, how much truth, a Shakespeare play contains, or a great novel. ${ }^{46}$

Volgens Murdoch is er niet alleen verschil in diepgang tussen kunst en filosofie ${ }^{47}$. maar ook in talige presentatie. De ideale filosofische stijl is ondubbelzinnig, helder en sober en laat geen ruimte voor de lezer. Filosofisch schrijven is in tegenstelling tot literair schrijven geen vorm van zelfexpressie, er dient geabstraheerd te worden van de persoonlijke stem. Ook andere auteurs die beide disciplines beoefenen. Sartre en De Beauvoir bijvoorbeeld, wijzen op de verschillende taalregisters. Sartre wisselt in zijn filosofisch werk literaire en filosofische stijlregisters af. In L'être et le néant (1943) bijvoorbeeld gebruikt hij een verleidingsscène om het idee van de mauvaise foi te illustreren. In Qu'est-ce que la littérature? (1948) stelt Sartre, dat alle schrijvers metafysische schrijvers zijn, want metafysica is geen steriele discussie over abstracte begrippen die niets te maken hebben met onze ervaring. Het is een poging om van binnenuit de condition humaine in zijn totaliteit te omarmen. Er moet volgens hem een literatuur komen die het metafysische absolute verzoent met de relativiteit van de historische situatie. ${ }^{48}$ Iets dergelijks vind je ook bij Simone de Beauvoir. Zij was van mening dat het existentialisme niet alleen op theoretische maar ook op fictionele wijze geformuleerd moest worden. In de essaybundel Oog om oog zegt De Beauvoir hierover het volgende:

Het is geen toeval dat het existentialistische denken zich heden ten dage zowel in theoretische verhandelingen als in fictie tracht uit te drukken; het doet immers een poging om het objectieve met het subjectieve, het absolute met het relatieve, het tijdeloze met het historische te verzoenen; het wil de essentie vatten die zich in het hart van het bestaan bevindt; en als de beschrijving van de essentie strikt genomen een ondercleel is van de filosofie, maakt alleen de roman het mogelijk de oorspronkelijke opwelling van het bestaan in haar volledige, eenmalige en tijdelijke waarheid op te roepen. Het gaat er hier niet om dat de schrijver vaststaande filosofische waarheden op een literair niveau benut, maar dat hij een aspect van de metafysische ervaring aantoont, dat op een andere manier niet kan worden aangetoond: haar subjectieve, eenmalige, dramatische karakter en eveneens haar dubbelzinnigheid; omdat de realiteit niet alleen via het intellect kan worden begrepen, kan geen enkele intellectuele beschrijving haar adequaat uitdrukken. Men moet proberen haar voor te stellen

\footnotetext{
46 zie 'Literature and Philosophy: A Conversation with Bryan Magee:' In: Iris Murdoch, Existentialists and Mystice. Writings on philosophy and litcrature. New York 1998: 11

47 Murdoch 1998: 21: "The unconscious mind is not a philosopher. For better and worse art goes deeper than philosophy:

48 ik heb gebruik gemaakt van de volgende editie: Jean-Paul Sartre, 'What is Literature?' In: 'What is. Litcnature?' and Other Essays Cambridge 1988: 21-246
} 
in haar volledigheid, zoals ze zich onthult in de levende relatie, die handeling en gevoel is voordat ze zich gedachte maakt. ${ }^{49}$

De literaire tekst is dus evocatief, de filosofische tekst is beschrijvend en analyserend. Daar komt bij, dat de filosofische ideeën in een literaire tekst, in tegenstelling tot de idecèn in een wijsgerig geschrift, niet wetenschappelijk getoetst hoeven te worden.

De relatie tussen filosofie en literatuur kan op verschillende manieren onderzocht worden. Twee modellen lijken me in dit verband relevant: het causalistische en het hermeneutische model, waarbij mijn voorkeur uitgaat naar het laatste model. ${ }^{50}$

In het causalistische model gaat de onderzoeker er niet alleen van uit dat een auteur beinvloed is door een wijsgerige opvatting, maar ook dat die filosofische invloed terug te vinden is in het literaire werk van de betreffende auteur. ${ }^{51}$ Hierbij doet zich een aantal problemen voor. Hoe stel je eenduidig en exact vast dat een auteur in filosofisch opzicht beïnvloed is? En als je al kunt aantonen dat een auteur graag bepaalde filosofen leest, impliceert dit dan dat het literaire werk van die auteur daar de sporen van draagt? Bovendien gat dit model uit van een filosofische bron, die dus eerder verschenen moet zijn dan het literaire werk. Het is echter gebleken, dat een jongere bron dienst kan doen als interpretatiekader voor een oudere literaire tekst. Zo kunnen Griekse tragedies en bepaalde bijbelverhalen bestudeerd worden vanuit een existentialistisch interpretatiekader. Ten slotte is het aanwijzen van een filosofische bron vaak een einddoel, terwijl het een beginpunt dient te zijn. De invloed moet vervolgens ook op tekstueel niveau zichtbaar gemaakt worden. ${ }^{52}$ Helaas ontbreekt het daar vaak aan in dit model.

In het hermeneutische model wordt het lieraire werk voor de lezer verhelderd met behulp van enkele filosofische noties. Bovendien worden in dit model de verschillen tussen literatuur en filosofie gerespecteerd, iets wat in het causalistische model onderbelicht of zelfs onopgemerkt blijft. Of de auteur van de betreffende literaire tekst die wijsgerige noties kent en daar inderdaad gebruik van heeft gemaakt is in dit model niet relevant. Het gaat erom of het inzetten van die noties interessante betekenissen en samenhangen oplevert en de lezer meer inzicht geeft in de literaire tekst. Zo kunnen de verhoudingen in een roman van Dostojevski

49 Simone de Beauvour, Oog om oog Essays. Tricht 1989:66

50 zie Hans van Stralen, 'Zelfontplooung en scepsis. De filosofie en de literatuur van het exastentialisme na de Tweede Wereldoorlog' In: Jaarboek voor litenatumuetenschap 1, 1998: 85-96. Het door Van Stralen besproken autonomiemodel en het analogische model lat ik hier buten beschouwing. Het autonomiemodel is slechts toepasbaar op ideeënromans. Dat is een te beperkt corpus literaire teksten om in dit algemene kader interessant te zijn. Het analogiemodel ontbreekt in mijn bespreking, omdat het nauweljks van het hermeneutische model te onderscheiden is.

51 dit model gaat ervan ut, dat de filosofie de literatuur beinvloedt. Er kan echter ook sprake zijn van elkaar wederzjjs versterkende denkbeclden. Zie: Lies Wesseling. "Van idecëngeschiedenis naar cultuurgeschiedenus. Over de ontwikkelingsgang van een interdisciplinaire onderzoekspraktijk: in: Tijdschrift noor litenatimurgechiedenis 1 (1998): 49-65.

52 zie Hans van Stralen 1998: 87-89 
meer reliëf krijgen door ze in een existentialistisch kader te plaatsen. In tegenstelling tot het causalistische model zit het hermeneutische model dus niet vast aan de dwang van de chronologie. ${ }^{53}$ Ook hier bestaat echter het gevaar dat het accent te veel op de filosofische ideeën komt te liggen, waardoor er te weinig aandacht is voor de literaire verwerking daarvan. Dat is bijvoorbeeld het geval in de studie Beschreven keuzes (1996), waarin Hans van Stralen, uitgaande van het hermeneutische model, de relatie tussen de existentiële fenomenologie en het literaire existentialisme bespreekt. In hoofdstuk II kom ik daar op terug.

\section{Besluit}

In tegenstelling tot wat Anbeek beweert, is het existentialisme kort na de oorlog al populair in Nederland bij filosofen, theologen en schrijvers. In eerste instantie is er vooral belangstelling voor existentialistische teksten die met de oorlog samenhangen, pas later worden romans als L'étranger en La nausée vertaald. De tweedeling in een existentialisme van de eenzaamheid en wanhoop enerzijds en een later ontstaan existentialisme van de morele keuze anderzijds blijkt niet correct te zijn, aangezien Sartre al in 1944 de nadruk legt op de vrijheid en de verantwoordelijkheid van de mens. Tot nu toe ontbrak er een bruikbare definitie van her literaire existentialisme. In het volgende hoofdstuk komen de voorstellen aan de orde die Hans van Stralen doet in zijn studie over het literaire existentialisme, Beschreven keuzes (1996).

53 zie Hans van Stralen 1998: 92-93 


\section{BESCHREVEN KEUZES: VOOR EN TEGEN}

\section{Afbakening van het literaire existentialisme}

In Nederland versehenen veel artikelen en boeken over het existentialisme, maar er zijn nauwelijks publicaties te vinden over de literaire variant daarvan. Als er al over geschreven wordt, wordt het belang ervan gebagatelliseerd of beperkt men zich tot een enkele auteur of tot een incidenteel werk. Een gunstige uitzondering hierop is de studie Beschreven keuzes (1996), waarin Hans van Stralen het literaire existentialisme als stroming benadert, uitgaande van het hermeneutische model. Hij plaatst enkele romans in de context van de existentiële fenomenologie ${ }^{1}$ met als doel deze literaire werken voor de lezer te verhelderen.

In de literatuurgeschiedenis wordt het existentialisme niet scherp genoeg afgebakend, aldus Van Stralen. De term 'existentialistisch' kan gebruikt worden voor literatuur waarin thema's als liefde en dood, absurditeit en zinloosheid van het leven voorkomen, zoals het boek Job, werk van Pascal en van Camus. Deze omschrijving is echter zo ruim, dat je je kunt afvragen welke teksten hier nog buiten vallen. In veel handboeken wordt het existentialisme vooral gezien als een filosofische stroming waar ook literaire teksten van filosofen toe behoren. In deze visie is een fictionele tekst vooral een middel om filosofische idecën over te dragen. Misschien gaat dit op voor literaire teksten van Sartre en De Beauvoir, maar niet alle auteurs van existentialistische romans waren naast literator ook filosoof. Bovendien kan het literaire existentialisme niet alleen maar begrepen worden vanuit de invloed die het filosofisch existentialisme daarop uitgeoefend zou hebben, aangezien auteurs als Böll en Blaman los van enige Franse ínvloed existentialistische romans hebben geschreven, aldus Van Stralen.

$\mathrm{Hij}$ noemt drie aspecten van waaruit je het literaire existentialisme kunt begrijpen: de existentiële fenomenologie, de gebeurtenissen rond de Tweede Wereldoorlog en de reactie op literaire conventies. Het gaat overigens niet altijd om concrete oorlogsgebeurtenissen, maar ook om de oorlog als fenomeen, als symbool van waanzin, desoriëntatie en ontgoocheling.

Van Stralen situeert het literaire existentialiśme in de periode 1935-1960. Het is echter de vraag of die afbakening ook voor Nederland geldt. Jaap Goedegebuure (2001) wijst erop dat de Nederlandse reactie op internationale vernieuwingen onderhevig is aan een zeker vertragings- of naijleffect. De Nederlandse reactie op stromingen als romantiek, naturalisme, symbolisme, expressionisme, surrealisme en existentialisme laat volgens hem zo'n patroon zien. ${ }^{2}$ Voor het literaire existentialisme moet dit nog nader onderzocht worden.

1 ve voor historische en inhoudelijke informatie over de exatentièle fenomenologie: Hans van Stralen 1996 : 23- 40. In paragraf 5 en 6 bespreek ik enkele aspecten van deze filosofie.

2 Jap Goedegebuure, Postmoderne modernisten en modernistische postmodernen Nederlandstalige schrijvers van de twintigste eeuw herlezen.' In: Nederlandse Letterkunde, jg. 6, nr. 1 januari 2001: 13-32 
Het literaire existentialisme begint rond 1935 als modernisten en avant-gardisten naar de achtergrond verdwijnen en de dreiging van het fascisme steeds groter wordt. Volgens Van Stralen eindigt zij rond 1960, als de actualiteit van de Tweede Wereldoorlog inmiddels plaats heeft gemaakt voor andere oorlogshaarden als Korea en Algerije en voor spanningen ten gevolge van de Koude Oorlog:

Met de temporele verwijdering van de oorlog verdwijnt ook de daaraan verbonden thematiek van het literaire existentialisme. ${ }^{3}$

Ik vraag me af of dit een adequate verklaring is. Van Stralen gaf eerder aan, dat het in existentialistische literatuur ook ging om de oorlog als fenomeen, waardoor het probleem dus boven de tijd uitstijgt. Je zou denken, dat juist in tijden waarin telkens nieuwe oorlogshaarden ontstaan en een Derde Wereldoorlog niet ondenkbaar wordt geacht existentialistische literatuur haar actualiteitswaarde behoudt. Een goed voorbeeld is La peste van Albert Camus, begonnen in 1939 en voltooid in 1944. Dit boek wordt nog steeds herdrukt en Camus staat op het moment met name in Amerika weer volop in de belangstelling. De 'pest' verwijst niet alleen naar de Nazi's, in Frankrijk la peste brune genoemd, of naar andere totalitaire regimes, maar ook meer in het algemeen naar de absurditeit van het bestaan. ${ }^{4}$ In het voorwoord van Readings. on The Plague (2001) wordt gesteld dat La peste relevant is voor hedendaagse lezers, omdat het gaat over de strijd tegen welke vorm van onderdrukking dan ook of over de strijd tegen vreselijke ziektes, in onze tijd bijvoorbeeld de aidsepidemie "war ook ailerlei politieke en morele kanten aan zitten. ${ }^{5}$

Van Stralens opmerking wordt bovendien gerelativeerd door het gegeven dat de oorlog ook jaren na de Tweede Wereldoorlog nog steeds een inspirerend thema blijkt te zijn, niet alleen in proza, maar ook in poëzie. Denk bijvoorbeeld aan het werk van Mulisch (De aanslag, 1982) en Armando, die in de poëzie het thema van het 'schuldige landschap' introduceerde. In Overal sporen (1990), een studie naar de verwerking van de Tweede Wereldoorlog in de Nederlandse literatuur, waarin overigens ñiet één kees naar het existentialisme wordt verwezen, stelt D. Schram dat het thema oorlog in de literatuur bijna even vanzelfsprekend is als het verschijnsel oorlog zelf. Zolang er literatuur is, is er oorlogsliteratuur. Verwerking van de Tweede Wereldoorlog is terug te vinden in een zeer groot aantal teksten van zeer uiteenlopende aard. Deze oorlog speelt een beslissende rol in het moderne bewustzijn en bepaalt direct of indirect de ervaringshorizon van zeer velen, aldus Schram. ${ }^{6}$

\footnotetext{
3 Van Stralen 1996: 196

4 zie bijvoorbeeld John Cruickshank, 'Levels of Meaning in The Plague.' In: Jess. G. Cunningham (ed.), Readings on The Plague. San Diego 2001:64-76

5 Jess G. Cunningham (ed.), Readings on The Plague. San Diego 2001: 12

6 D. Schram, 'Taal behoudt de feiten. De verwerking van de Tweede Wereldoorlog in de literatuur.' In: D.H.Schram en C. Geljon, Ovenal sporen. De venuerking war de Tivecde Wereldoorlog in litenatuar en kumst. Amstendam 1990: 93-126.
} 
Van Stralen geeft ook een literair-historisch argument om de ondergang van het existentialisme te verklaren. Op literair niveau ontstond er een verschuiving: een dominante positie werd ingenomen door de nouvau roman, waarin niet zo zeer het vertellen van een verhaal centraal stond en de psychologische achtergronden van de personages als wel de zakelijke beschrijving van waarneembare objecten (école du regand of res-istentialisme) en het experimenteren met literaire vormen. Gerichtheid op ethische kwesties of politiek engagement ervoer men als een inbreuk op de artistieke vrijheid. Veel nouveau romanciers gingen uit van de onkenbaarheid van de werkelijkheid, ze waren minder geinteresseerd in politieke problemen, waarvan het belang gerelativeerd werd. Literair engagement had dan ook geen prioriteit. Dit argument is niet geheel overtuigend. Zijn argumentatie betreft vooral de Franse situatie, waarin Sartre en De Beauvoir een leidende stem hadden in het literaire en politieke discours. Bovendien betreft deze kritiek vooral de ethische variant van het literaire existentialisme, waarin politiek engagement meer dan in de esthetische variant een rol speelt. De vraag is echter of dit ook voor de Nederlandse situatie opgaat. Om een antwoord op die vraag te kunnen geven zou eerst meer vergelijkend onderzoek gedaan moeten worden. In ieder geval schuwde een schrijver als Mulisch het politieke engagment in de jaren zestig niet, getuige De zaak 40/61 (1962) over het proces van Eichmann, Bericht aan de rattenkoning (1966) over de Provobeweging en Het woord bij de daad (1968) over de Cubaanse revolutie. Ook in andere kunstvormen was men in Nederland in die tijd niet afkerig van politiek engagement, getuige het politieke cabaret (Lurelei bijvoorbeeld), het geëngageerde toneel, het populaire én verguisde televiesieprogramma Zo is het toevallig ook nog eens een keer en de populariteit van de protestsong in de jaren zestig, mede onder invloed van Bob Dylan en Donovan die zich in hun teksten fel verzetten tegen de Vietnam-oorlog.

In Nederland raakte het existentialisme op de achtergrond, omdat de Vijftigers na 1950 het literaire klimaat domineerden en omdat er meer temporele afstand was tot de Tweede Wereldoorlog, aldus Van Stralen. Ook zouden schrijvers van na 1945 geen behoefte hebben aan nieuwe ideologieën. ${ }^{8}$ Hierbij zijn een paar kanttekeningen te plaatsen. Allereerst is het niet duidelijk hoe en waarom een poëziebeweging ẹn volgens Van Stralen vooral op proza gerichte beweging kan wegdrukken. Verder blijkt uit diverse publicaties, dat het existentialisme enige aantrekkingskracht uitoefende op Vijftigers als Kouwenaar, Campert en Schierbeek. $^{9}$

Bovendien waren er in Nederland wel degelijk schrijvers die kort na de oorlog (nog) geloofden in een nieuwe maatschappij, en dat waren opmerkelijk genoeg vooral dichters. De Vijftigers, van wie een aantal radicaal communist was, hadden

7 Siem Bakker (red.), Nieuue literatuargeschiedenis. Overzidht van de Europese letteren van Homerus tot heden. Deel III van 1900 tot heden. Amsterdam 1994: 1198-1205

8. zie ook Hans van Stralen, "Zelfontplooring en scepsis. De filosofie en de literatuur van het exastentialisme na de Tweede Wereldoorlog.' In: Jaarbock voor litenatuunuetensechap I, 1998: 85-96.

9 zie hoofdstuk VI. 
duidelijk een optimistische toekomstverwachting. In een interview relativeert Kouwenaar, in de jaren vijftig redacteur van De Waarheid, de stelling dat auteurs de eerste jaren na de oorlog geen belangstelling meer hadden voor ideologieën:

Er was bij de Vijftigers wel degelijk een politieke grondslag. Maar de vraag was: hoe maak je een nieuwe kunst die 'socialistisch' is, zonder in de valkuil te trappen van het socialistisch realisme. Dat was ons dualisme. Hoe moest je de theorie verzoenen met wat er in de praktijk door de avant-garde naar voren was gestoken? De hele westerse kunstwereld was in de eerste jaren na de oorlog communistisch georiënteerd, behalve de voorzichtige Nederlandse kunstenaars. $^{10}$

Het literaire existentialisme is volgens Van Stralen geografisch beperkt tot vooral Frankrijk en Duitsland. Hij voert daar twee argumenten voor aan: allereerst waren beide landen intensief betrokken bij zowel de Eerste als de Tweede Wereldoorlog met alle existentiële problemen die daardoor opgeroepen worden. Ten tweede kenden beide landen een lange traditie van reflexieve filosofie in tegenstelling tot bijvoorbeeld. Engeland, waar vooral de beoefening van de analytische filosofie belangrijk was. Ik vraag me af of het historische argument genoeg gewicht heeft, aangezien Engeland bij beide Wereldoorlogen betrokken was en toch ook de nodige slachtoffers te verwerken had. Het verschil in filosofische traditie acht ik een aannemelijker argument, hoewel iemand als de Engelse filosoof en schrijver Iris Murdoch in de jaren 1950-1959 een aantal publicaties liet verschijnen over het existentialisme. ${ }^{11}$

Volgens Van Stralen was men vooral geïnteresseerd in het filosofische existentialisme; het literaire existentialisme nam in Nederland slechts een zeer bescheiden plaats in. Eind jaren veertig, begin jaren vijftig verschenen er diverse studies over het filosofische existentialisme, dat met name op christelijke theologen een zekere aantrekkingskracht had als bron van nieuwe impulsen voor de christelijke geloofsbeleving. Van Stralen beperkt zich hier tot het filosofische existentialisme, maar vermeldt niet dat de invloed van de existentiële fenomenologie verder reikte: niet alleen de theologie, maar ook disciplines als psychologie en sociologie werden erdoor beïnvloed. Wel merkt hij op dat in de jaren negentig belangrijke aspecten van het existentialisme gemeengoed zijn geworden. In de zogenaamde damesbladen werden adviezen gegeven vanuit een existentialistische invalshoek, waarin het accent kwam te liggen op de eigen verantwoordelijkheid en het aanvaarden van de vrijheid. ${ }^{12}$

In Nederland verschenen er slechts incidenteel literair-existentialistische teksten, aldus Van Stralen. Hij noemt het werk van Anna Blaman, Hermans, Reve, het

10 in: H.J.A. Hofland en Tom Rooduijn, Duvars door puinstof heen. Grondleggers uan de naoorlogse litenatuur. Met documentaire over de Vijftigers op cd. z.p. 1997: 53

11 Iris Murdoch, Existentialists and Mystics. Writings on Philosophy and Litenture. New York 1997

12 zie Hans van Stralen 1996: 72 
vroege werk van Bert Schierbeek en de poëzie van Ellen Warmond en Vasalis. Het tijdschrift Libertinage bevatte ook publicaties die literair-existentialistisch te noemen zijn door het accent op morele problematiek en de eigen positionering daartegenover. Ook tijdschriften als Opuaartsche Wegen en Criterium bevatten teksten die in een literair-existentialistische context te plaatsen zijn. In zijn boek beperkt Van Stralen zich wat de Nederlandse situatie betreft helaas tot het werk van Anna Blaman en in zijn algemeenheid tot proza.

Zijn conclusie dat het literaire existentialisme niet zo'n grote rol heeft gespeeld, lijkt me voorbarig. De stelling, dat diverse auteurs al snel braken met de existentialistische problematiek, roept vraagtekens op. Van een auteur als Hermans bijvoorbeeld is bekend dat zijn thematiek niet wezenlijk veranderd is in de loop der tijd. Van Stralen houdt ook geen rekening met het door Goedegebuure (2001) genoemde vertragings- of naijleffect. Bovendien laat Van Stralen de poëzie geheel buiten beschouwing in zijn studie. ${ }^{13}$ Het lijkt me dan ook aanbevelenswaardig dat er meer deelstudies komen naar literair-existentialistisch werk van Nederlandse auteurs, zowel wat proza als poëzic betreft. ${ }^{14}$

\section{Filosofische aspecten}

In zijn boek gaat Van Stralen uitgebreid in op de filosofische achtergronden vạn het literaire existentialisme. Het filosofische existentialisme vormt geen afgerond geheel, maar over het algemeen is men het erover eens, dat filosofen als Karl Jaspers (1883-1969), Martin Heidegger (1889-1976) en Jean-Paul Sartre (1905-1980) ertoe behoren, ondanks de onderlinge verschillen. ${ }^{15}$ De jonggestorven Deense denker en predikant Søren Kierkegaard (1813-1855) wordt als de belangrijkste voorloper beschouwd.

De kern van het filosofische existentialisme is het begrip 'existentie', dat niet duidt op het bestaan in zijn algemeenheid, maar op het concrete menselijke bestaan. Centraal staat de vraag hoe je in het leven staat en welke houding je aanneemt ten aanzien van de belangrijke levensvragen. Zelfreflectie speelt daarbij een belangrijke rol. In tegenstelling tot een ding kan een mens keuzes maken binnen een paradoxale en contingente werkelijkheid. Hij is vrij om zijn eigen bestaan vorm te

13 voor kritick op het buiten beschouwing laten van de poëzic, zie hoofdstuk VI 'Existentialisme en poëzie:

14 Smeets 1997: 128-130 wijst er terecht op, dat het moeilijk bljft eventucie Nederlandse existentialistische romans aan te wijzen zo lang nog niet adequat omschreven is wat existentialistische literatuur precies is. Net als hij ben ik ervan overtuigd dat er meer te vinden is dan alleen dat werk waar literatuurhistorici tot nu toe op gewezen hebben. Smeets stelt voor met name het werk van Rodenko, Pierre Dubois en Cola Debrot nader te onderzoeken. Ook Wim Berkelaar noemt in zijn bespreking van Van Stralens studie het werk van Pierre Dubois (zie: Wim Berkelaar, 'Als literatuur vermomde ethiek. Een beschouwing over het literaire existentialisme' In: Vooys, vol. 15, afl. 1, 1997: 29-36). Maaike Meijer stelt voor het werk van Hanny Michaelis te onderzoeken op affiniteit met het existentialisme.

15 Smeets 1997: 119 voegt daar nog Gabriel Marcel (1889-1973) aan toe; in de jaren vijttig verdwijnt. Marcel naar de achtergrond en neemt Maurice Merleau-Ponty (1908-1961) zijn plaats in. 
geven. Omdat de mens telkens opnieuw binnen een concrete situatie aan zichzelf vorm moet geven, is er geen sprake van een afgeronde essentie. De existentialistische mens is altijd onderweg. Er is sprake van kwade trouw (mauvaise foi), als iemand geen gebruik maakt van zijn vrijheid van handelen, maar zich conformeert aan wat bijvoorbeeld 'men' of de kerk zegt. Met name in het werk van Sartre zijn de mauvaise foi en de gevolgen daarvan belangrijke thema's. Ze contrasteren met thema's als vrijheid en engagement, aldus Van Stralen.

\section{Ethische en esthetische variant}

Op het moment dat hij zich bewust wordt van zijn vrijheid zijn er volgens Kierkegaard drie leefwijzen waar de mens voor kan opteren: de esthetische, de ethische en de religieuze. De esthetische mens is vooral gericht op het tijdelijke en het zichtbare. Hij heeft een hedonistische inslag, in tegenstelling tot de ethische mens die zich verbindt met zijn medemens en de gemeenschap. De religieuze mens verbindt zich niet alleen met zijn naaste en de gemeenschap, maar ook met God.

Zich baserend op Kierkegaards indeling onderscheidt Van Stralen twee lijnen binnen het literaire existentialisme: de ethische variant, waarvan Sartre een representant is en de esthetische variant met als representant Albert Camus. Het derde aspect, de religieuze variant, zou volgens Van Stralen binnen het literaire existentialisme geen rol van betekenis hebben gespeeld. De religieuze variant wordt mijns inziens door Van Stralen iets te snel buiten spel gezet. In een stroming als het personalisme, dat ook wel de 'zachte' variant van het existentialisme ${ }^{16}$ wordt genoemd, voelden de daarbij behorende auteurs zich verwant met "christelijke" existentialisten als Kierkegaard, Jaspers en Gabriel Marcel. De laatste was overigens niet, alleen filosoof maar ook toneelschrijver. De Engelse auteur Graham Greene zou je een katholieke existentialist kunnen noemen, hoewel hij zichzelf geen katholiek schrijver noemt, maar een schrijuver die toevallig katholiek is.

Van Stralen beperkt zich tot de ethische en de esthetische variant. Deze twee vormen staan niet diametraal tegenover elkaar, wel is er sprake van een accentverschil. In de ethische variant ligt het accent op de onrechtvaardigheid van de werkelijkheid. Literatuur heeft binnen deze opvatting een persuasieve en activerende functie. Centraal staat het vertrouwen in vooruitgang: als mens heb je de mogelijkheden om de maatschappelijke werkelijkheid uiteindelijk te veranderen. De aandacht is gericht op de toekomst.

In de esthetische variant ligt het accent op volledige aanvaarding van de realiteit met al haar negatieve en positieve facetten. De maatschappelijke werkelijkheid is volgens Camus uiteindelijk niet te veranderen, er zal altijd een breuk blijven tussen onze existentie en onze idealen, wat niet wegneemt dat je destructieve krachten moet bevechten. De aandacht is gericht op het hier en nu. In het werk van Camus

16 het personalisme ontstond irt 1930 in Frankrijk rond het tijdschrift Esprit. Het wordt een 'zachte' vorm van het existentialisme genoemd, omdat het bepaalde scherpe kanten van Sartres filosofic afwijst. 
spelen levensaanvaarding en verheerlijking van de natuur een grote rol. Dit betekent overigens niet, dat wanhoop en depressie niet voor kunnen komen. Het gaat er echter om dat je je lot, gelijk Sisyphus, waardig ondergaat.

Wat de Nederlandse situatie betreft: Van Stralen plaatst Blamans werk binnen het esthetisch existentialisme, omdat er heimwee naar een oorspronkelijke fase uit spreekt, gecombineerd met het besef dat het menselijk tekort niet op te heffen is. Alleen liefde en erotiek kunnen dat, ook al is dat slechts tijdelijk.

Van Stralen stelt terecht, dat de term 'esthetisch' aanleiding kan geven tot misverstanden. Hij erkent, dat in het werk van Camus ook ethische kwesties aan de orde worden gesteld, alleen gebeurt dat op een andere manier dan in het werk van Sartre. Hoewel beiden een menswaardiger samenleving voorstaan, zou Sartre vooral voor de revolutie kiezen: een ingrijpende verandering van de maatschappelijke verhoudingen. Camus zou zich beperken tot de revolte: een opstand op individueel niveau die de maatschappelijke verhoudingen in feite niet aantast.

$\mathrm{Bij}$ dit onderscheid past een kanttekening. Het is opmerkelijk dat Sartres bekendste roman La nausée niet in het door Van Stralen aangegeven stramien past. In deze roman ligt het accent op de individuele problematiek van de hoofdfiguur. Het boek bevat weliswaar een aantal maatschappij-kritische opmerkingen, maar politieke acties die gericht zijn op het veranderen van de maatschappij spelen hierin geen enkele rol. Dat is wel het geval in Camus' toneelstuk Les justes (1949), dat gebaseerd is op Sonvenirs d' un terroriste van de Russische terrorist en schrijver Boris Savinkow (1879-1925). In het toneelstuk bereidt een groep terroristen een aanslag voor op de grootvorst Alexei. Degene die de bom zal gooien, Yanek Kaliayew, heeft zich bij de terroristen aangesloten, omdat hij uit compassie voor zijn medemens het leven voor iedereen leefbaar wil maken. Toch kent zijn actiebereidheid grenzen: de eerste aanslag gaat niet door, omdat er in de koets, van de grootvorst ook een kind blijkt te zitten. Pas als de grootvorst alleen is, gooit hij de bom. ${ }^{17}$ Het revolutiethema komt dus ook in het werk van Camus voor, al is dat minder frequent dan in het werk van Sartre. Volgens Van Stralen kan men in plaats van esthetisch existentialisme beter spreken van existentialisme van de levenskunst. Maar deze vervangende aanduiding is evenmin onproblematisch. Waarom zou het ondernemen van politieke actie niet ook een vorm van levenskunst kunnen zijn?

Ondanks bovengenoemde bezwaren vind ik de termen 'ethisch' en 'esthetisch' acceptabel en werkbaar, zolang men zich er maar bewust van is, dat het globale aanduidingen zijn. Ze geven geen contrast maar een accentverschil aan. Ook moet men ervoor oppassen de term 'ethisch' te reserveren voor het werk van Sartre en de term 'esthetisch' voor het werk van Camus, zoals blijkt uit de voorbeelden La nausée en Les justes.

17 zie: FO. van Gennep, Albert Camus. Een studie vin zijn ethische denken. Amstendam $1966^{2}: 177-182$ 


\section{Kenmerken}

Van Stralen noemt drie kenmerken, die afgeleid zijn van de existentiële fenomenologie: de grenssituatie, de ander en het engagement. Ze zijn onlosmakelijk met elkaar verbonden. De term 'grenssituaties' is ontleend aan het werk van de existentie-filosoof Karl Jaspers en kan als volgt omschreven worden:

situaties die ons tot aan de grenzen van ons bestaan brengen en onze hele existentie schokken. Het zijn situaties van het absolute toeval, van het conflict, van het lijden, van de schuld en van de dood. Deze situaties brengen ofwel tot vertwijfeling en overweldigen ons, ofwel zij wekken ons op tot een keuze van ons eigenlijke ik en van ons lot. ${ }^{18}$

Vrijwel elke literair-existentialistische tekst begint met een situatie waarin het personage nog geen duidelijk inzicht in zijn leven heeft of waarin het zich vervreemd voelt. Vervolgens komt hij door overmacht in de vorm van een heftige gebeurtenis als bijvoorbeeld ziekte, aanslag of oorlog onder druk te staan, waardoor er een bedreigende grenssituatie ontstaat. Er ontstaat een existentiële crisis. In deze grenssituatie komen gevoelens als schaamte, angst, walging en het besef sterfelijk te zijn in alle hevigheid naar boven. Omdat deze realiteit niet te ontkennen valt, ervaart het personage in eerste instantie de absurditeit van zijn bestaan. Door middel van zelfreflectic probeert hij te komen tot een heroriëntatie op zijn situatie. Als hij beseft dat hij niet totaal onderworpen is aan de realiteit, maar dat hij een zekere mate van vrijheid kent, vindt er een soort ontwaken plaats. Hij wordt zich bewust van de 'breuk' tussen ervaring en rede, tussen ik en de ander, tussen het pre-rationele en het rationele domein. ${ }^{19}$ De ander (als individu, als collectief of geinternaliseerd in innerlijke dialogen) kan zijn wereld onder druk zetten. Op het moment dat hij beseft dat hij moet kiezen, staan hem drie wegen open. Ten eerste de totale berusting, omdat de menselijke vrijheid als beperkt wordt ervaren. Hier is sprake van een echec, vaak eindigend met zelfdestructieve neigingen. Ten tweede aanvaarding als resultaat van een heroriëntatie op de werkelijkheid. Het personage heeft zich aangepast aan zijn situatie, hij is sadder but wiser. Erotiek is een middel om het leed te verlichten. Ten slotte een groot vertrouwen in de menselijke vrijheid en verantwoordelijkheid voor de maatschappij en voor de ander, waardoor de situatie daadwerkelijk wordt veranderd en verbeterd.

Volgens Van Stralen is elke bewuste beslissing een vorm van engagement, dat in zijn visie niet noodzakelijk een politiek engagement hoeft te zijn. Het is een:

levenshouding die in de vorm van gerichte opvattingen en keuzes blijk geeft van betrokkenheid met de persoonlijke situatie en die van de ander, keuzes die

18 Fritz Heinemann, Existentiefilosofie: levend of dood? Utrecht-Antwerpen 1967: 65-66.

19 hier gaat Van Stralen uit van het conflictmodel van Sartre. Dat er ook een andere visie mogelijk is. wordt in paragraf $5 \mathrm{en} 6$ van dit hoofdstuk besproken. 
voltrokken worden vanuit inzicht in een gespannen situatie die voor het personage tijdelijk onoverzichtelijk is geweest. ${ }^{20}$

Een karakteristiek literair-existentialistisch motief is de authentieke buitenstaander, die onafhankelijk ten opzichte van door maatschappij of traditie opgelegde normen en waarden wil leven. Een tweede kenmerkend motief is dat van de gesloten ruimtes. Kelders, cellen, bordelen en dergelijke zijn plaatsen die een spanning creèren tussen vrijheid en beperking, waardoor het personage geconfronteerd wordt met zichzelf of met de ander. Het existentiële misverstand of de absurditeit is. een derde motief. Bij Camus is het de spanning tussen een gerechtvaardigd verlangen naar geluk en de niet-rechtvaardige werkelijkheid. Tenslotte het motief van de negatieve handeling, dat wil zeggen de bewust niet-voltrokken handeling op het moment dat zich een grenssituatie voordoet. In La peste van Camus bijvoorbeeld stelt de bevolking zich apathisch op, zij volhardt in deze houding, terwijl de situatie om actie vraagt. In Les mains sales van Sartre denkt Hugo dat hij geen vuile handen makt door niet in actie te komen.

Van Stralen noemt ten slotte nog een tweetal existentialistische karakteristieken. Allereerst de geseculariseerde invulling van christelijke begrippen. ${ }^{21}$ Zo gaat 'zonde' de onherstelbare fout tegen de medemens betekenen of 'hel' de vergiftigde situatie met de ander. God wordt vaak voorgesteld al's een seniele oude man, om aan te geven dat het traditionele religieuze systeem niet of nauwelijks meer levensvatbaar is.

Verder is er eerder sprake van menstypen (de avonturier, de bourgeois, de authentieke mens) dan van round characters. Personages vertegenwoordigen diverse levensstijlen en het eventuele échec daarvan.

Hoewel Van Stralen een belangrijke aanzet heeft gegeven tot het onderzoek naar het literaire existentialisme is zijn aanpak niet helemaal overtuigend. Mijn kritiek op zijn aanpak betreft allereerst de grote nadruk op Sartre. Ook is er in Beschreven keuzes te weinig aandacht voor de literaire technieken van het literaire existentialisme, dat ondanks de grote invloed van de filosofie immers ook een literaire kant heeft.

Van Stralen stelt terecht dat de existentiële fenomenologie een interpretatief kader is waarmee diverse auteurs zinvol en coherent onder één noemer geplaatst kunnen worden -namelijk die van het literaire existentialisme- vanwege de grote thematische verwantschap die er tussen beide bestaat. De thema's zijn, evenals de door hem genoemde motieven en andere karakteristieken, heel bruikbaar als een roman onderzocht moet worden op literair-existentialistische kenmerken, zoals zal blijken uit de analyse van Warmonds Paspoort voor niemandsland in de volgende hoofdstukken.

20 Van Stralen 1996: 59

21 Van Stralen. (1996:69-70) spreekt in dit verband van een 'antropocentrische' invulling van christelijke begrippen. Deze aanduiding lijkt me minder adequat, angezien antropocentrisme en christendom elkaar niet hoeven uit te sluiten. 
De meeste auteurs benadrukken dat het literaire existentialisme niet beperkt is tot de invloed van Sartre, om zich vervolgens vrijwel alleen te baseren op de ideeën van deze filosoof-schrijver. Zo ook Van Stralen. Het werk van de fenomenoloog Merleau-Ponty, dat door Van Stralen slechts zijdelings; wordt genoemd, is echter minstens zo interessant in dit verband, met name zijn ideeën over pre-reflexiviteit, lichamelijkheid en vrijheid.

\section{Pre-reflexiviteit en lichamelijkheid: Sartre versus Merleau-Ponty}

Zowel Merleau-Ponty als Sartre waren niet tevreden met de overwegend rationalistische tendens van de Franse filosofie. Merleau-Ponty houdt zich vooral bezig met de pre-reflexieve, pre-conceptuele gebieden van de ervaring, terwijl Sartre gefocust is op het probleem van de menselijke vrijheid en zijn implicaties. In 1955 viel Merleau-Ponty Sartre aan in zijn boek Les avontures de la dialectique. Hij is het niet alleen oneens met diens. 'ultra-bolsjewisme', maar ook met diens theorie over de verhouding tussen lichaam en bewustzijn.

Als fenomenoloog gaat Sartre uit van het intentionaliteitsconcept: het menselijk bewustzijn is nooit in pure vorm aan te treffen. Het is altijd een verhouding tot het zijn. Zien, liefhebben of vertrouwen is altijd iets of iemand zien, liefhebben of vertrouwen. Een los van het lichaam gedachte psyche acht men binnen de fenomenologie onmogelijk. Affecties, stemmingen en gedachten drukken zich in het lichaam uit. Sterker gezegd: lichaamsuitsdrukkingen zijn mijn psyche. Als ik lach, is dat niet een uiting van mijn blijdschap, het is de blijdschap zelf. Als mijn wenkbrauwen omhoog gaan, is dat geen uiting van mijn verbazing, het is de verbazing zelf, enzovoorts. In dit licht bezien is het lichaam zelfs het psychisch object bij uitstek. Mét en dóór mijn lichaam ben ik in de wereld, ben ik een lichaam-in-een-situatie: Ik 'ben' mijn lichaam en ik 'ben' het niet: ik heb een verhouding tot mijn lichaam en tegelijk ben ik dit lichaam. Mijn lichaam is namelijk ook mijn instrument, waardoor ik in contact kan treden met de wereld en waardoor ik kan handelen. Op die manier transcendeer ik het. Ik 'ben' mijn hand, maar tegelijkertijd ben ik mét mijn hand bij de dingen die ik voel en doe. ${ }^{22}$

Sartre onderscheidt een cerstegraads en een tweedegraads bewustzijn. Het eerstegraads bewustzijn is pre-reflexief en onpersoonlijk of voor-persoonlijk, dat wil zeggen: het vertoont nog geen Ik-structuur, maar kan wel altijd tot object van reflectie gemakt worden, waardoor het principieel de mogelijkheid biedt een Ik te laten verschijnen. Het ego verblijft volgens Sartre namelijk niet in het bewustzijn, het is niet bewustzijnsimmanent, met andere woorden het ego is geen bewoner van het bewustzijn, het is daarentegen een product van diens activiteit.

In het tweedegraads bewustzijn word je je bewust van het pre-reflexief bewustzijn. Het is een versterking van de reflectie, die Sartre de echte reflexiviteit noemt.

22 zie onder andere H. Redeker, Existentialisme. Een doortocht door philosophisch frontgebied. Amsterdam 1949: 313 c.v. 
Vanwege de mogelijkheid tot introspectie spreekt men ook wel van het getuige-bewustzijn. ${ }^{23}$ Het bewustzijn kent per definitie een zekere mate van reflexiviteit, want een bewustzijn dat zich niet in enigerlei vorm ook van zichzelf bewust is, zou gekarakteriseerd moeten worden als onbewust bewustzijn, wat volgens Sartre een absurditeit is: ${ }^{24}$

Het bewustzijn bestaat, zoals een boom of een grassprietje bestaat. Het dommelt, verveelt zich. [...] Maar het vergeet zich zelf nooit; het is zich ervan bewust een bewustzijn te zijn dat zich zelf vergeet. Dat is zijn lot. ${ }^{25}$

De genoemde bewustzijnsgraden bepalen ook de manier waarop ik mijn lichaam beleef: als immanent of als transcendent lichaam. Andere termen voor immanent en transcendent lichaam zijn respectievelijk lichaam-als-subject en lichaam-als-object of Leib en Körper. Gezien hun compactheid geef ik de voorkeur aan de laatste termen. Mijn Leib is mijn lichaam voor zover dit door mij in het ongereflecteerde stadium doorleefd wordt. Het is het lichaam dat voelt en ervaart. Door het fenomeen van de blik word ik mij ervan bewust dat mijn lichaam een object is voor de ander als ik zijn objectiverende blik op mij gericht voel. Op die momenten ervaar ik mijn lichaam in het tweedegraads bewustzijn als Körper: mijn lichaam al's object en instrument voor de ander, waarbij de "ander" een ander mens kan zijn of het reflecterende ik. Het subject is zich ervan bewust dat er twee essentieel verschillende en onverzoenlijke ervaringsniveaus zijn, aldus Sartre.

Door het probleem op deze manier te benaderen komt Sartre niet los van een cartesiaans dualisme, waardoor hij gekarakteriseerd kan worden als een cartesiaans fenomenoloog. ${ }^{26}$ Merleau-Ponty daarentegen is een post-cartesiaans fenomenoloog, omdat hij een non-dualistische fenomenologie voorstaat. Het fenomenale lichaam is de oorsprong van zowel de immanente als de transcendente aspecten van lichamelijkheid. Het objectieve lichaam, het lichaam als chemisch bouwwerk of als een verzameling weefsels is niet de waarheid van het fenomenale lichaam, het is er slechts een verarmde afbeelding van en heeft alleen een begripsmatig bestaan. ${ }^{27}$ Volgens Merleau-Ponty kan de lichaamservaring niet omschreven worden op basis van het model 'sensor ontvangt prikkels', omdat zo'n model geen adequaat beeld geeft van hoe het is om een fenomenaal lichaam te zijn. Als ik bijvoorbeeld mijn vinger aanraak, ervaar ik een 'dubbele sensatie', namelijk aanraken en aangeraakt worden. Sartre onderscheidt twee verschillende en onderling gescheiden niveaus: het lichaam als subject en het lichaam als object. In plaats van dit conflictrnodel gaat Merleau-Ponty uit van een amhiguiteitsmodel. Het is een essentieel kenmerk van

\footnotetext{
23 zie: Jean-Paul Sartre, Het $l k$ is een Ding. Meppel/Amsterdam $1988^{2}: 13$

24 Sartre $1988^{2}: 20$

25 Jean-Paul Sartre, Walging. Amsterdam $1990^{11} ; 233$

26 voor deze paragraaf heb ik onder andere gebruik gemaakt van: Martin C. Dillon, 'Sartre on the Phenomenal Body and. Merleau-Ponty's Critique' In: Jon Stewart, The Debate betueen Sartre and Merleau-Ponty. Evanston 1998: 121-143

27 zie: M. Merleau-Ponty, Fenomenologie uan de usarneming. Amsterdam 1997: 492 (oorspronkelijk Phénomenologie de ia perception, 1945)
} 
lichamelijkheid dat beide aspecten op beide niveaus simultaan maar ambigu bestaan. Het fenomenale lichaam is geincarneerd bewustzijn, zowel immanent als transcendent, zowel subject als object van zijn ervaring. De twee conflicterende polen komen voort uit een realiteit die zowel één als ambigu is, namelijk het fenomenale lichaam.

\section{Vervreemding of verzoening?}

Fenomenologie is een proces waarin zoveel mogelijk vooronderstellingen worden ontmanteld (de fenomenologische reductie), om uit te komen bij datgene wat primair is (de zidetische reductie). Volgens Merleau-Ponty is het mogelijk een direct en primitief contact met de wereld terug te krijgen. Hij heeft het over het opnieuw wakker maken van de basiservaring, waarvan de wetenschap een uitdrukking op tweedegraads niveau is. De wereld is primair, analyse is secundair. Merleau-Ponty is op zoek naar deze pre-reflexieve, pre-conceptuele wereld. Er is niet eerst sprake van bewustzijn en dan pas van ervaring, het bewustzijn is direct met de wereld verbonden, zonder onderscheid. Niet de waarneming, maar het denken laat ons onderscheid ervaren tussen subject en object. ${ }^{28}$

Volgens het Sartriaanse conflictmodel ontstaat er vervreemding, omdat het pre-reflexieve en het reflexieve niveau twee essentieel verschillende en onverzoenlijke ervaringsniveaus zijn. In het ambiguiteitsmodel van Merleau-Ponty is een verzoening niet alleen mogelijk, maar constant en alomtegenwoordig. Aan vervreemding ligt volgens hem een primair verlangen naar gemeenschappelijkheid ten grondslag. Vervreemding ontstaat wanneer het verlangen naar eenheid gefrustreerd wordt door uitsluiting, als er anders-zijn is in plaats van de verwachte solidariteit en verbondenheid. We ervaren de blik van anderen niet als pijnlijk, omdat we fundamenteel van hen gescheiden zijn, maar omdat kijken of bekeken worden in bepaalde situaties de plaats in kan nemen van een positievere relatie of het verlangen daarnaar.

Sartre beschrijft de blik in termen van macht. In zijn conflictmodel wordt de ander niet ontdekt in het kijken, maar in het bekeken worden. Het fenomeen van de blik, dat wil zeggen de gewaarwording bekeken te worden, maakt de aanwezigheid van de ander voelbaar. De observerende blik van de ander maakt mij tot object, zoals ik op mijn beurt de ander tot object kan maken door observerend terug te kijken. Die observerende en verdingelijkende blik wordt ervaren als een inperking van de eigen vrijheid. De blik waarover Sartre spreekt is een speciale blik, die door hem gegeneraliseerd wordt. Hij reduceert alle vormen van samen-zijn tot één grondpatroon: het conflict tussen het hatelijke kijken en het hatelijke bekeken-worden. Er bestaan echter ook nog andere vormen van kijken: de welwillende, vergevende, begrij-

28 zie Leo Rauch, 'Sartre, Merleau-Ponty, and the "Hole in Being"'. In: Jon Stewart, The Debate betueen Sartre and Merleau-Ponty. Evanston 1998: 1-15 
pende, aansporende en liefdevolle blik bijvoorbeeld, aldus de fenomenoloog Luijpen. ${ }^{29}$

Merleau-Ponty heeft een minder verengde opvatting van samen-zijn. In zijn ambiguiteitsmodel staat het communicatieve element van de blik centraal. Dat ik een. lichaam ben, betekent dat ik als object kan worden gezien, maar tevens dat ik als subject wil worden gezien. De blik van de ander makt mij niet tot object en vice versa, tenzij we beiden onze blik onmenselijk laten worden waardoor we het gevoel krijgen geobserveerd te worden als een insect. Maar zelfs dan worde de blik van de ander alleen als pijnlijk gevoeld, doordat deze de plaats van een mogelijke communicatie inneemt. ${ }^{30}$

Het verschil in opvatting uit zich ook in de manier waarop beide filosofen de sexuele intimiteit beschrijven. Sartre presenteert zijn visie weliswaar sekseneutraal, maar in feite getuigt zijn conflictmodel van een eenzijdige, traditioneel-mannelijke benadering. In zijn Fenomenologie van de waarmeming presenteert Merleau-Ponty een andere visie. Hij benadrukt, dat er sprake is van circulariteit van aangeraakt worden en aanraken. Aanraken kun je niet onderverdelen in enerzijds de aanraking en anderzijds het passief aangeraakte object. In de aanraking verdwijnt het onderscheid tussen het aanrakende subject en het aangeraakte object, tussen activiteit en passiviteit. Er is eerder sprake van het wederzijds doordringen van grenzen dan van confrontatie en toeèigening. Lichamelijkheid is een medium voor wederzijds contact. De onderliggende basis is de wederkerigheid. Merleau-Ponty vervangt dus het traditionele onderscheid tussen actief en passief door het principe van de wederkerigheid.

In zijn artikel 'Touch and Vision: Rethinking with Merleau-Ponty Sartre on the Caress $^{31}$ gat Glen A. Mazis in op de verschillen tussen beide filosofen wat dit onderwerp betreft. Sartre gaat ten onrechte uit van een conflictmodel. Als je het lichaam van de ander tot louter passief object reduceert, kun je je afvragen of er wel sprake is van liefkozen. De kenmerken van de Sartriaanse blik zijn tegengesteld aan de liefdevolle sexuele intimiteit, aldus Mazis. In plaats van weg te zinken in passiviteit, als inkt in een vloei (een beeld van Sartre), word je je ervan bewust een belichaamd bewustzijn te zijn. Door de wederkerigheid van de aanraking ontstaat er een samen-zijn met de ander waarin er noch een subject noch een object is. Mazis vindt het veelzeggend dat Sartre de betekenis van de sexuele intimiteit vanuit een analogie met het kijken verklaart. Volgens Sartre is er sprake van een liefkozing als niet alleen de ander 'vlees in mijn ogen' is geworden, maar ook 'vlees in zijn eigen ogen'. Beide uitdrukkingen benadrukken het visuele aspect. De taal van de emoties is echter tactiel: ik word geraakt door iets, ik voel liefde. De taal van de rationele reflectie is visueel: ik zie iets in, een nieuw inzicht. De wereld van het visuele, die gekenmerkt wordt door afstand en begrensdheid, is essentieel voor de wereld

29 zie: W. Lujpen, Nieuve inleiding tot de existentiele fenomenologie. Utrecht/Antwerpen 1969:344

30 zie M. Merleau-Ponty 1997: 419

31 in: Jon Stewart, The Debate between Sarte and Merleau-Ponty. Evanston 1998: 144-153 
van het in bezit nemen. Sartre stelt: wat gezien wordt, wordt bezeten of toegeeigend. Dat geldt in zijn visie ook voor de coïtus. Hier is sprake van agressie en confrontatie, aldus Mazis. Wat dit punt betreft staat het Sartriaanse conflictmodel tegenover het ambiguïteitsmodel van Merleau-Ponty. ${ }^{32}$

\section{Absolute of geconditioneerde vrijheid?}

De existentiële fenomenologie spreekt in dubbele zin over vrijheid: negatief geformuleerd drukt vrijheid een zekere afwezigheid van determinatie uit en positief geformuleerd een zekere autonomie. De mens is meer dan het resultaat van processen en krachten. Er is nooit volledige determinatie, maar ook nooit volledige vrijheid. Volgens Merleau-Ponty heeft het vrijheidsconcept alleen betekenis, als het tegendeel -de beperktheid of gebondenheid- tegelijkertijd bestaat. Om over vrije daden te kunnen praten, moeten we ook weten wanneer er sprake is van een niet-vrije daad. Als iedereen noodzakelijkerwijze vrij is, wordt het vrijheidsconcept betekenisloos, want dan zijn er geen hindernissen meer. Vrijheid is alleen maar mogelijk in gebondenheid.

Beide aspecten spelen in het ambiguiteitsmodel van Merleau-Ponty tegelijkertijd een rol. Wereld en individu beïnvloeden elkaar wederzijds, dat geldt ook voor individuen onderling. De ander is niet (alleen maar) een beperking van of een aanval op mijn vrijheid, zoals in het conflictmodel van Sartre. Vrijheid is altijd een kunnen-zijn vanuit een bepaalde situatie, de zogenaamde facticiteit, zoals nationaliteit, hoogte van het IQ, mate van gezondheid en financiële positie. Die facticiteit sluit bepaalde mogelijkheden in en andere mogelijkheden uit. Deze opvatting acht absolute vrijheid dus niet mogelijk. ${ }^{33}$

Volgens Sartre ben je zelfs in de meest nare omstandigheden vrij. Tijdens de bezetting bijvoorbeeld had je in ieder geval altijd nog vrijheid van gedachten. ${ }^{34}$ De vraag is echter in hoeverre je in dat geval over vrijheid kunt spreken, aangezien die vrijheid beperkt is tot het denken en zich niet uitstrekt tot het handelen. Volgens Merleau-Ponty heeft Sartre een stoïsche kijk op vrijheid. Stoïcisme verschijnt

32 zie voor een reactic op Merleau-Ponty's ideeën. Ethique de la difference sexuelle (1984) van Luce Irigaray. Zij baseert zich daarin op Le visible et l'invisible (Parijs 1964), cen latere studie van Merleau-Ponty. Dit boek verscheen drie jaar na zijn dood. Het bestaat gedeeltelijk uit aantekeningen die zijn vriend en medewerker Claude Lefort verzameld en uitgegeven heeft. [Informatie ontleend aan de inleiding van vertalers Rens Vlasblom en Douwe Tiemersma bij: M. Merleau-Ponty. Fenomenologie uan de uxarneming (Amsterdam: 1997:21)]. Omdat Irigarays kritick geen betrekking heeft op Merleau-Ponty's Phénoménologie de la perception (Parijs 1945), de studie waarop ik me in mijn boek baseer, ga ik hier verder niet op in.

33 zie: M. Merleau-Ponty, Fenomenologie un de waameming. Amstendam 1997:514-515

34 Sartre erkent overigens wel, dat de maatschappij de voorwaanden en de begrenzing van de individuele vrijheid vormt. Zie: Van Stralen 1996: 128 en Stewart 1998: 197-214. Volgens de lastste kan Sartre op dit punt eenvoudig verkeend begrepen worden, omdat hij (= Sartre) zijn visie presenteert door middel van allerlei paradoxale formuleringen. Sartre heeft echter nooit ontkend dat vrijheid belemmend kan worden. 
historisch gezien altijd in perioden van hulpeloosheid en onderdrukking, zoals indertijd in het Romeinse keizerrijk en later tijdens de bezetting van Frankrijk in de Tweede Wereldoorlog. Tijdens de bezetting was je vrij om je terug te trekken in het rijk van je gedachten. Dit stoïsch escapisme is geen werkelijke vrijheid, maar de 'droom van gevangenen', aldus Merleau-Ponty. ${ }^{35}$

\section{Literaire technieken}

Evenals Anbeek 1986 en Ruiter / Smulders 1996 presenteert Van Stralen het literaire existentialisme als een literaire stroming, hoewel het hier geen stroming in de traditionele zin van het woord betreft. Er is immers geen sprake van groepsvorming of van manifesten. Sartres belangrijkste poèticale geschrift, waarin hij onder meer zijn idecën over romankunst en over poëzie ontvouwt, Qu'est-ce que la littérature?, dateert van 1948, zijn roman La nausée van $1938 !^{36}$ Daar staat tegenover dat ook het inmiddels algemeen als stroming erkende modernisme geen manifesten kende. De term 'modernisme' ontstond pas in 1960 als een constructie achteraf. In zijn essay 'What was Modernism?' (1960) karakteriseert Harry Levin het modernisme als een literair-historisch verschijnsel, dat onder meer plaats heeft moeten maken voor het documentair realisme en de existentialistische roman. ${ }^{37}$

Niet alleen groepsvorming en/of manifesten zijn van belang voor het onderscheiden van een literaire stroming. Ook stilistische vernieuwing, nieuwe genres en accentuering van ethische problematiek kunnen daarin een rol spelen. Zodra een literair-historische constructie enige bekendheid onder vakgenoten heeft gekregen, kan ze als analytisch concept een verhelderende rol vervullen in het historiografisch onderzoek, aldus Fokkema en Ibsch in Literatuurvetenschap en cultuuroverdracht. ${ }^{38}$ Van Stralens constructie van het literaire existentialisme is op te vatten als zo'n analytisch concept, dat interessante betekenissen en samenhangen genereert.

Terecht wijst Van Stralen erop, dat het literaire existentialisme zich vooral inhoudelijk laat definiëren, omdat er nauwelijks formele innovaties zijn. Hij besteedt in zijn analyses van een aantal existentialistische romans en toneelstukken weinig aandacht aan fictionele technieken, omdat er volgens hem al goede studies over bestaan. Een van die studies is Existential Thought and Fictional Technique van Edith Kern, waar Van Stralen alleen en passant naar verwijst. ${ }^{39}$ Aangezien het existentialisme per slot van rekening ook literaire gevolgen had, zal ik in deze studie niet alleen aandacht besteden aan de filosofische achtergronden, maar ook aan de literaire vormgeving.

35 zie: Jon Stewart, 'Merleau-Ponty's Criticisms of Sartre's Theory of Freedom.' In:Jon Stewart 1998: $197-214$

36 in hoofdstuk VIII ga ik in op Sartres idecèn over poëzie

37 gegevens ontleend aan: Douwe Fokkema / Elrud Ibsch, Het Modermisme in de Europese letterkunde. Amsterdam 1984: 10

38 Muiderberg 1992: 85-87

39. Edith Kern, Existential Thought and Fictional Technique. Kierkegaard, Sartre, Beckett. New Haven and London 1970 
Een interessante aanvulling op de criteria van Van Stralen is het onderzoek van de Amerikaanse Edith Kern naar fictionele technieken in het werk van Kierkegaard, Sartre en Beckett. In navolging van. Sartre stelt zij, dat er een bepaald verband is tussen de levensvisie van een auteur en de fictionele technieken die hij gebruikt. ${ }^{40}$ Zowel Kierkegaard als Sartre en Beckett gaan ervan uit, dat het individu opgesloten. zit binnen de horizon van zijn eigen bewustzijn, waardoor hij de ander alleen onvolledig en slechts gissenderwijs kan begrijpen. Zo'n visie moet invloed hebben op de menselijke relaties binnen de door de auteur gecreëerde fictionele wereld. De techniek van de 'omniscient author', die immers inzicht heeft in het innerlijk van de personages, is uiteraard niet meer bruikbaar. Een ander gemeenschappelijk. uitgangspunt is de subjectiviteit van de waarheid. Een literaire vorm waarin deze subjectiviteit tot haar recht komt, is de ik-vorm. Dat geldt ook voor literaire teksten in de derde persoon, als er sprake is van een 'masking of a first-person situation', aldus Kern. Deze vormen beperken de informatie aan de lezer tot het bewustzijn en de kennis van de ik-figuur. Een andere techniek is het gebruik maken van 'varying points of view'. Hierdoor worden meerdere geïsoleerde bewustzijnen getoond, die misschien wel op elkaar kunnen reageren, maar elkaar alleen via generaliseringen, hypothesen en gissingen kunnen leren 'kennen'. De lezer moet erop bedacht zijn, dat de door de personages gegeven informatie onbetrouwbaar kan zijn. ${ }^{41}$

Vormen waarin het op zichzelf teruggeworpen zijn ook voelbaar en zichtbaar wordt, zijn het dagboek, brieven, monologen en dromen. Al deze vormen hebben ook nog andere voordelen: ze beperken het zicht van de lezer tot het gezichtspunt van het personage en ze geven uiting aan de onmiddellijkheid van het bestaan, 'the dramatic vividness of an action taking place before one's very eyes. ${ }^{42}$

Een andere fictionele techniek is de ironische distantie. Voor Kierkegaard hangt ironie nauw samen met het concept van de subjectiviteit. Deze stijlfiguur stelt de spreker/schrijver in staat afstand te nemen ten opzichte van zichzelf. Hij kan over zichzelf reflecteren als ware hij een derde persoon. Daar komt bij, dat het paradoxale karakter van het leven het beste weergegeven kan worden door middel van het contradictoire en ambivalente karakter van de ironie.

Een belangrijk middel on de geïsoleerde bewustzijnen tot interactie te laten komen is de blik. Door de blik van de ander wordt iemand zich van zichzelf bewust en dat bevestigt op zijn beurt weer het bestaan van de ander. Door de blik als fictionele techniek te gebruiken kan de auteur het solipsisme van zijn personages doorbreken en ze meerdimensionaal maken. Bepaalde metafoorpatronen kunnen het isolement van de personages benadrukken, zoals de eilandmetafoor in het werk van Samuel Beckett.

Simultaneitteit is een andere geliefde fictionele techniek in existentialistische romans. In Le sursis (1945), het tweede deel van de romancyclus Les chemins de la

40 zie Jean-Paul Sartre, 'What is Litenufure?' and Other Essays. Cambridge 1988

41 Kern 1970: 135-136

42 Kern 1970: 25 
liberté, maakt Sartre hier in diverse passages gebruik van, bijvoorbeeld in het begin van het eerste hoofdstuk:

\section{Vrijdag 23 september}

Zestien uur dertig in Berlijn, vijftien uur dertig in Londen. Het hotel verveelde zich op zijn heuvel, verlaten en plechtstatig, met één grijsaard binnen zijn muren. In Angoulème, in Marseille, in Gent, in Dover dachten ze: 'Wat doet hij? Het is al over drieën, waarom verroert hij zich niet? ${ }^{43}$

Nog een voorbeeld uit deze roman: het einde van zaterdag 24 september (Ivich en Philippe zijn romanpersonages):

De trein reed, het schip steeg en daalde, Hitler sliep, Ivich sliep, Chamberlain sliep, Philippe wierp zich op zijn bed en begon te huilen $[\ldots]^{44}$

In beide passages is er een associatieve verbinding tussen gebeurtenissen, plaatsen en personages die anders niet met elkaar samenhangen. Kern vraagt zich af of Sartre hier gebruik maakt van het procédé van de 'omniscient author', die in staat is alles waar te nemen wat zich op diverse plaatsen en in diverse bewustzijnen afspeelt. Hij lijkt hiermee te voldoen aan het ideaalbeeld dat Flaubert had van de schrijver. In Flauberts visie opereert de schrijver als God tijdens de schepping: onzichtbaar en almachtig, overal voelbaar maar nergens opgemerkt. Flaubert gebruikt tussen de simultane passages echter verbindingswoorden, die een bepaald ordeningsverband suggereren. Sartre doet dat niet, de verteller heeft zich geheel weggecijferd, aldus Kern.

Het gebruik van kleine ruimten als cellen en kelders als décor voor de existentialistische problematiek en het classificatieprocẹédé zijn al in ẹn ẹdere paragraaf besproken.

In tegenstelling tot Van Stralen 1996 benadert Kern het existentialisme niet als een periodeconcept, aangezien ze zowel de fictionele technieken in het werk van de negentiende-eeuwse Kierkegaard als in dat van de twintigste-eeuwse Sartre en Beckett uitvoerig bespreekt. Wat het werk van de laatste twee auteurs betreft: Kern gaat niet in op het feit dat ze vooral gebruik maken van modernistische literaire procédés. Wel wijst ze op surrealistische echo's in het werk van diverse existentialisten: koortsachtige beelden, een lunaire wereld en metamorfose. Die metamorfose kan verbeeld worden als een personificatie van objecten en/of als een depersonificatie van personen (bijvoorbeeld handen die vissen worden).

43 Jean-Paul Sartre, De wegen der vrijheid II. Her oponthoud. Amstendam/Antwerpen 1952: 5 (vertaling Maurits Mok)

44 Sartre 1952: 161 
Kerns studie laat zien dat het zinvol is om de existentialistische problematiek in relatie tot de literaire technieken te bestuderen. In de volgende hoofdstukken onderzoek ik onder andere op welke wijze Warmond in haar roman Paspoort voor niemandsland de daarin aanwezige existentialistische problematiek op literaire wijze vormgeeft.

\section{Conclusie}

Van Stralen 1996 stelt, dat in het literaire existentialisme de wil tot (herstel van) contact met de 'Lebenswelt' domineert. ${ }^{45}$ Terecht gebruikt hij de existentiële fenomenologie als interpretatiekader. Het is echter niet terecht dat hij alleen het conflictmodel van Sartre als basis neemt. Sartre is, door vast te houden aan een cartesiaans dualisme, geen echte fenomenoloog. Zijn stelling, dat de breuk tussen de mens (het pour-soi ofwel het bewustzijn) en het zijnde (het en-soi) onherstelbaar is, blijkt discutabel te zijn. De post-cartesiaanse fenomenologie laat zien, dat er in de pre-reflexieve ervaring geen sprake is van een breuk; die ontstaat namelijk pas op tweedegraads niveau door de rationele reflectie. Het ambiguïteitsmodel van Merleau-Ponty kan bij het bestuderen van literair-existentialistische teksten een nieuw licht werpen op aspecten als pre-reflexiviteit, lichamelijkheid, vervreemding, de blik, sexuele intimiteit en vrijheid. Deze aspecten krijgen door dit model meer reliëf en meer diepgang dan in het enigszins eenzijdige, want stereotiep-mannelijke, Sartriaanse conflictmodel. Sartre presenteert zijn visie ten onrechte als sekseneutraal. Het is de vraag of zijn visie overeenkomt met de primaire, onderliggende pre-reflexieve en pre-conceptuele ervaring.

Aangezien er sprake is van een combinatie van filosofie en literatuur is het belangrijk inhoudelijke aspecten waar mogelijk in relatie tot de literaire vormgeving te bestuderen. Voor de inhoudelijke component heeft Van Stralen de nodige bouwstenen angedragen, wat de formele/literaire component betreft zijn de bevindingen van Edith Kern heel bruikbaar.

Het werk van Warmond zal laten zien dat het literaire existentialisme zich niet alleen manifesteert in genres als roman en toneel, maar ook in poëzie. Van Stralen 1996 gaf al aan, dat de gedichten van Warmond, Vasalis en de vroege Schierbeek hierop onderzocht zouden kunnen worden. In zijn studie over Kouwenaar ging Kusters onder andere in op existentialistische sporen in de gedichtencyclus 'weg/verdwenen' (1961). ${ }^{46}$ Het heeft dus zin ook de poëzie erbij te betrekken. In hoeverre dit consequenties zal hebben voor de omvang en de periodisering van het literaire existentialisme in Nederland dient nader onderzocht te worden. Dit onderzoek, dat helaas buiten het kader van mijn studie valt, zal duidelijk moeten maken of het literaire existentialisme in Nederland inderdaad zo beperkt is gebleven als tot nu toe gesuggereerd werd.

45 Van Stralen 1996: 65

46. Wiel Kusters, De killer. Over poëzie en poettica un Gerrit Kounenaar. Amstendam 1986: 179 e.v. 


\section{PASPOORT VOOR NIEMANDSLAND}

\section{Inleiding}

In 1961 verscheen Warmonds eerste en enige roman Paspoort voor niemandsland. In datzelfde jaar publiceerde ze ook de dichtbundel Warmte, een woonplaats en Eeuvig duurt het langst, een verzameling korte verhalen, columns en grotesken. Veel van Warmonds gedichten uit de periode 1953-1966 blijken inhoudelijk affiniteit te vertonen met bepaalde gedachten uit het filosofische existentialisme. De vraag is of dit ook opgaat voor Warmonds roman, aangezien diverse recensenten op inhoudelijke overeenkomsten met Warmonds poëzie wijzen. ${ }^{1}$

Dat wordt in dit en de volgende hoofdstukken onderzocht aan de hand van de criteria die Van Stralen 1996 heeft opgesteld voor het literaire existentialisme, dat immers inhoudelijk overeenkomsten vertoont met de filosofische variant. Waar mogelijk zal ik, geïnspireerd door Kern 1970, inhoudelijke aspecten verbinden met de literaire vormgeving. In dit hoofdstuk ligt het accent op de fictionele technieken die Warmond gebruikt in haar roman Paspoort voor niemandsland.

Paspoort voor niemandsland is een niet-chronologisch vertelde psychologische roman, bestaande uit 26 hoofdstukken. Bovendien zijn er zeven cursieve passages, waarvan sommige wat essayistisch aandoen. In deze roman staat de keuzeproblematiek centraal: de keuze tussen leven en dood, tussen erotiek en vriendschap, tussen terugvallen in alledaagse zekerheden of opnieuw vormgeven aan je leven. Iedere pool van deze keuzeproblematiek wordt gerepresenteerd door een bepaald personage ${ }^{2}$ :

\section{Bert}

vriendschap

kunstenaar

\section{Esther}

erotiek

dood

\section{Hans \\ vriendschap \\ erotiek \\ reklametekenaar}

\section{Jaap}

vriendschap

burger

\section{Eva}

erotiek

leven

\footnotetext{
1 ze bijvoorbecld Renate Rubinstein, 'Ellen. Warmond als prozaschrijfster." In: Nịcuwe Rotterdamse Counant 25 november 1961 en Jan van der Vegt, 'Ellen Warmond'. In: Kritisch Literatuur Lexicon. Groningen 1984

2 de in het schema genoemde vrouwelijke personages hebben van Warmond geen beroep gekregen. Van Esther weten we alleen, dat ze Engels heeft gestudeerd, niet of ze dar beroepsmatig iets mee doet. In hoofdstuk IV en V ga ik dieper in op de verschillende verhoudingen.
} 
Informatie over de personages wordt aangeleverd via innerlijke monologen, gesprekken, brieven en dromen. Er is overwegend sprake van een externe vertelinstantie. Daarnaast komt de gedachte- en gevoelswereld van meerdere personages aan bod. Buiten de hoofdpersoon Hans Erkelens treden met name zijn jeugdvriend Jaap "zijn kennis. Jacques de la Rive, zijn voormalige geliefde Esther en zijn leermeester Bert Masson als focalisator op. De weinige vertellerstekst die er is, beperkt zich vooral tot het aangeven van overgangen in tijd, plaats en handeling. Als er al sprake is van vertellerscommentaar, is dat uitsluitend impliciet en niet van wezenlijk belang voor de interpretatie van het verhaal. De in deze vlugge schets genoemde aspecten zullen, evenals hier nog niet genoemde elementen, in de volgende hoofdstukken uitgebreider besproken worden.

De roman begint op het moment, dat de hoofdpersoon, Hans Erkelens (27), zich na een bezoek aan zijn chirurg in een crisissituatie bevindt. Hij had zich voorbereid op de dood, aangezien zijn vader, broer en enkele ooms van hem overleden zijn aan keelkanker. Zijn situatie blijkt echter niet alarmerend te zijn. De nacht ervoor heeft hij in een monoloog eerlijker dan ooit de balans opgemaakt van zijn leven, in het bijzijn van zijn in slaap gevallen jeugdvriend Jaap. Hij voelt zich mislukt: in plaats van kunstschilder is hij reclametekenaar geworden.

In zijn stamkroeg de Olympus krijgt Hans het aan de stok met Jacques de la Rive, een fatterig heerschap dat iedereen verveelt. De la Rive loopt kwaad weg. In een apart hoofdstuk, dat enigszins losstaat van de rest van het verhaal, staan De la Rives ideeën over lichamelijkheid en sexualiteit centraal. Onderweg naar huis denkt De la Rive onder andere na over de promiscuïteit van zijn vrouw Connie, die zowel relaties met mannen als met vrouwen heeft. Hij denkt met name terug aan de keer, dat hij Connie een keer thuis aantrof met een andere vrouw, beiden in badjas. De la Rive aarzelt echter over de aard van hun relatie, aangezien de vrouw, waarschijnlijk Hans' ex-vriendin Esther, in het geheel niet voldoet aan het beeld dat hij heeft van homosexuele vrouwen.

Vlak nadat De la Rive kwaad is weggelopen ontmoet Hans in de Olympus Eva Wever, vrouw van cen rijke worstfabrikant. Zij vraagt hem of hij haar portret wil schilderen als verjaarscadeau voor haar echtgenoot. Zijn vriend en leermeester Bert Masson is niet te spreken over Eva, die al vele minnaars heeft gehad, onder wie hijzelf. Hans moet voor de kunst kiezen, in plaats voor gemakkelijke succesjes bij rijke dames. Het komt tot een breuk tussen de beide vrienden. In diezelfde periode pleegt Esther, de ex-vriendin van Hans, in een hotel zelfmoord.

Hans voelt zich door Eva als herboren, zij is zijn paspoort voor het land der levenden. Als hij Eva enige tijd daarna in Biarritz opzoekt, blijkt hun relatie niet meer zo levendig te zijn als voorheen. Op een terrasje in Parijs beseft hij zijn echec. Hij bedrinkt zich, gaat hallucineren en ervaart het Niets op zijn hotelkamer.

Terug in Nederland ontmoet hij Bert weer, met wie hij enkele schilderijen van een bevriend schilder weg gaat brengen voor een tentoonstelling. Als Bert diezelfde dag 
overlijdt, voelt Hans zich totaal ontredderd. Hij vlucht als een haas die in het wilde weg rent, omdat er van alle kanten op hem geschoten wordt.

\section{Vertelsituatie}

In de roman Paspoort voor niemandsland wisselt Warmond een externe vertelinstantie af met technieken als de personage-gebonden verteller en de personage-gebonden focalisator. De lezer maakt met name nader kennis met de gedachte- en gevoelswereld van de personages Hans Erkelens, Bert Masson en Esther Engelrijk. Hierdoor wordt een veelzijdig beeld opgebouwd van de diverse personages. De lezer kan de verschillende visies op elkaar en op de gebeurtenissen met elkaar vergelijken en tot een eigen conclusie komen. Dit is echter niet eenvoudig. In hoeverre zijn bijvoorbeeld de verhalen van Esther betrouwbaar, aangezien Hans haar een fantaste noemt? Dat geldt ook voor de visie van Hans, die volgens zijn leermeester van iedereen een karikatuur maakt. Zo ontstaat er bij de lezer een verwarrende onzekerheid. Die onzekerheid wordt nog eens versterkt door de diverse incongruente visies van de personages onderling. Enkele voorbeelden. De la Rive heeft een heel ander beeld van zichzelf dan de mensen in zijn omgeving. Hij vindt zichzelf fijnzinnig en cultureel, terwijl anderen hem slechts een onuitstaanbare 'ouwehoer' vinden. Ook de visies van Esther en Hans op Bert Masson congrueren niet met elkaar. Esther prikt door de idealiserende visie van Hans heen. Verder blijkt, dat de visies van Bert en Esther op Hans niet overeenkomen. Bert beschouwt hem nog steeds als een veelbelovend kunstenaar. Hans is zich echter bewust van zijn beperkingen op artistiek gebied, vandaar zijn keuze voor de reclame. Bovendien spelen financiële overwegingen bij deze keuze een rol. Esther vindt haar ex-geliefde een betweterige 'padvinder', die niet voor zichzelf denkt, maar alleen de woorden van zijn leermeester kan, herhalen.

Deze meervoudige vertelwijze hangt samen met een existentialistisch kernpunt: eenieder bestaat in het bewustzijn van de ander op een manier die hij niet heeft gekozen, de ander makt de selectie die hij zelf wil. Degenen die zich op die manier gedacht voelen, voelen zich tegelijkertijd gevangen en zelfs geketend in het bewustzijn van de ander. Het is iets waar ze geen invloed op hebben. Door de concrete blik van de ander weet het personage dat de ander een constructie van hem makt. De techniek van meerdere personage-gebonden focalisators laat de lezer als in een meervoudig spiegelbẹ de existentiële eenzaamheid zien van de diverse personages in hun geïsoleerde bewustzijnen. Deze manier van vertellen beeldt daarmee ook het gebrekkige contact tussen de personages onderling uit. Is deze kloof te overbruggen? In het conflictmodel van Sartre, waarin de ander als de vijand van het ik wordt beschouwd, is dat niet mogelijk. In het ambiguiteitsmodel van Merleau-Ponty daarentegen neemt het begrip coëxistentie een belangrijke plaats in. Net als de wereld is de ander er altijd als aspect van mijn ervaringswereld. Zowel de ander als ik zijn beiden existentie, gericht op de wereld. Daarom is er 
sprake van coëxistentie. Dat betekent dat we elkaar op zijn minst gedeeltelijk begrijpen. De Sartriaanse visie vind ik bij Warmond niet terug. Haar romanpersonages zijn geen vijanden van elkaar. Als ze teleurgesteld zijn in anderen, komt dat juist omdat er een onderliggend verlangen is naar coëxistentie.

In hoofdstuk VI past Warmond een andere techniek toe om het isolement van een personage te accentueren. Dit hoofdstuk is op de eerste en laatste alinea na, die uit vertellerstekst bestaan, een monologue intérieur van Jacques de la Rive. In deze innerlijke monoloog (p.38-44) treedt De la Rive op als een personage-gebonden verteller. De lezer krijgt informatie over de manier waarop De la Rive tegen zichzelf aankijkt, zijn verhouding tot lichamelijkheid en zijn visie op met name homosexuele vrouwen. Zijn visie op lichamelijkheid, een belangrijk motief in deze roman, correspondeert niet met die van de andere personages. Deze gesegregeerde visie wordt literair vormgegeven door de overgang naar een andere manier van vertellen, een vorm die in de rest van de roman niet voorkomt. Dit hoofdstuk vormt als het ware qua inhoud en vertelvorm een eiland in de rest van de roman. De techniek van de personage-gebonden verteller benadrukt in dit geval niet alleen de ik-gerichtheid van De la Rive, maar ook zijn isolement binnen zijn huwelijk en andere sociale verbanden.

Je zou op basis van deze gegevens 'De la Rive' kunnen interpreteren als een programmatische naam. 'Rive' betekent immers 'kant' of 'oever'. De Franse achternaam roept al iets op van deftigheid. Jacques de la Rive voelt zich verheven boven de anderen, waardoor hij van zichzelf een buitenstaander maakt. Niet alleen plaatst hij zichzelf buiten de zijlijn, anderen doen dat ook met hem. Door zijn arrogantie en 'geouwehoer' laten anderen hem links liggen. Zijn afkeer van lichamelijkheid veroorzaakt een verwijdering met zijn vrouw Connie, die zich vervolgens uitleeft in promiscue gedrag. De la Rive laat het over zijn kant gaan. Hij zegt er niets van en accepteert het lijdelijk, omdat hij dit alles beneden zijn niveau acht.

Warmond gebruikt dus zowel het procédé van de programmatische naam als van een afwijkende vertelvorm om de geïsoleerde positie van dit personage op literaire wijze vorm te geven. Er gebeurt op perspectivisch vlak nog iets opmerkelijks. Hoewel Eva in de roman een belangrijker rol speelt dan Jacques de la Rive treedt zij, in tegenstelling tot de andere hoofdpersonages, niet of nauwelijks als focalisator op. Haar visie op haar relatie met Hans wordt alleen op indirecte en fragmentarische wijze duidelijk, als Hans niet geheel onbevooroordeeld aan selecties uit haar afscheidsbriefje terugdenkt. Ze blijft een enigszins mysterieuze figuur, over wie de lezer alleen via andere personages iets te weten komt. Die vrijwel geheel afwezige focalisatie wordt hier als literaire strategie ingezet. Ze accentueert, dat Eva voor Hans niet zo zeer een persoon is als wel een functie. Hij is vooral verliefd op zijn fantasie-Eva, die voor hem als zijn 'paspoort voor het land der levenden' fungeert. De minieme focalisatie heeft nog een andere functie in deze roman. Ze geeft het gebrek an persoonlijkheid en eigenheid van dit personage aan. Eva's grapjes en spitsvondigheden 'waren kopieën, alleen vermakelijk zolang je het origineel niet kende' 
(p.124). Ze verzamelt altijd veel mensen om zich heen, omdat ze volgens Hans vooral via anderen leeft:

Zonder die achtergrond merkte je pas hoezeer ze afhankelijk was van dat beweeglijke décor, alsof al die mensen spiegels waren waarin ze zich kon laten weerkaatsen en waarin ze kon schitteren. Zonder die entourage was ze eigenlijk vrij saai, weinig spraakzaam, een beetje slaperig, passief suffend in een lauw soort tevredenheid die hij slecht bij haar vond passen. (p.151)

\section{Cursieve passages}

Dat deze roman een hechte structuur kent, blijkt onder andere uit het feit, dat zeven hoofdstukken ${ }^{3}$ cursief gedrukte passages bevatten die op een bepaalde manier met elkaar samenhangen. Er zijn drie groepen te formeren, ieder met een eigen functie. In deze passages blijken lay-out, registerwisselingen en afwijkende werkwoordstijden belangrijke markeerders te zijn. Allereerst de inhoud van de verschillende cursieve passages:

1. terugblik naar de eerste klas van de HBS, waar Hans Erkelens zijn eerste deceptie ondergaat: is dit nou een leraar?

2. aan de vooravond van het beslissende gesprek met de chirurg raakt Hans in een existentiële crisis, waarin hij zijn leven tot nu toe overdenkt

3. in een vitalistisch visioen stelt Jaap Viergever zich voor dat hij als Hans ontwaakt en uitbundig zal gaan leven

4. een beschouwende passage over angst, dood en liefde

5. terugblik waarin Hans op zijn zeventiende de beperktheid van het ouderlijke milieu ervaart tegenover de lossere manier van leven in het schildersmilieu

6. Hans ziet het vervolg van zijn relatie met Eva voor zich als een filmscenario, wat een vervreemdend effect heeft

7. een beschouwende passage over dood, liefde en tijd

\section{Eerste groep}

Het samenbindende element van de eerste groep (eerste en vijfde passage) is relativering en ontmaskering van autoriteiten. Uit de eerste passage blijkt, dat Hans zich heel wat had voorgesteld van de HBS die een nieuwe fase in zijn leven zou betekenen. In plaats daarvan slaan zijn hoge verwachtingen tijdens de eerste lesdag al om in deceptie:

Was dit nu een leraar? Die bleke vogelverschrikker in zijn kale, grijze pak, met glanzende ellebogen en moedeloos-diepe knieën in zijn broek? Hij had

3 het betreft de hoofdstukken $1: 7-9 ; 2: 17-19 ; 3: 22-23 ; 13: 96-97 ; 16: 117-119 ; 21: 153$ en 26 : 191-192 
verwacht dat een leraar iemand zou zijn, die duidelijk meer was dan een meester. Een man waar je 'meneer' tegen moest zeggen [...] (p.7)

In deze eerste passage worden onvoltooid en voltooid verleden tijd afwisselend gebruikt. De laatste vorm wordt vaak toegepast om aan te geven dat de ene gebeurtenis vóór de andere plaatsvond. Het verhaal over de eerste middelbare-schooldag staat in de onvoltooid verleden tijd, terwijl de verwachtingen ten aanzien van school en leraren die Hans van tevoren had in de voltooid verleden tijd staan. Beide tijden geven hier het contrast aan tussen verwachting en realiteit.

In een klasgenote die de leraar eveneens op spottende wijze bekijkt, vindt Hans een medestandster, waardoor de kiem gelegd wordt voor zijn houding ten aanzien van latere teleurstellingen:

Zonder het zich te realiseren nam hij zich yoor, meer intuïtief dan beredeneerd, voor alle situaties iemand te zullen zoeken, die op het moment van de onvermijdelijke teleurstelling bereid zou zijn 'púh!' te zeggen, hem daarmee verlossend uit het isolement dat de ontgoocheling met zich meebracht ...(p.8)

In de vijfde passage maakt de lezer kennis met Hans' visie op zijn ouders, die in hun winkel 'de symbolen van de kleinburgerlijke aanpassing en onderdanigheid' verkochten: teilen en keukentrapjes, 'een parodie op de maatschappelijke ladder'. De angst voor wat 'men' zegt en de kleingeestigheid worden als het ware gepersonifieerd in Hans' ouders, die op vlijmscherpe wijze gepresenteerd worden als representanten van de kleinburgerlijkheid:

Ze leefde in een bangelijke, onderdanige vrees voor het oordeel van god en de mensen, met het accent op de mensen, want de hemel was ver weg, maar de buren kwam je dagelijks tegen. (p.117)

Hij had nog beter overtuigd N.S.B.-er kunnen zijn, dan wist je waar je je tegen verweren moest, maar als hij nu aan zijn. vader terugdacht, dan zag hij alleen een geborneerde kool-en-geit-spaarder, een betweterige, bekrompen kleinburger en een principeloze opportunist. (p.118)

In scherp contrast hiermee staan de mensen die thuishoren in het kunstenaarsmilieu van zijn leermeester Bert, dat in vrijwel alles het tegendeel lijkt te zijn van de kleinburgerlijke bekrompenheid van zijn ouderlijk milieu. Zij laten zich niet leiden door een autoriteit van buitenaf, of dat nou God of 'men' is. Daardoor leek het Hans of deze mensen 
in een ander land en in een ander klimaat leefden. God kenden ze alleen als een abstractie, een ander woord voor menselijke waardigheid, en van 'de mensen' hadden ze nooit gehoord. (p.118)

\section{Tweede grocp}

De delen van de tweede groep vormen een temporele lijn: ze laten zien hoe Hans' leven was (tweede passage), hoe het zou kunnen worden (derde passage) en hoe het uiteindelijk geworden is (zesde passage), waarbij opvalt dat verleden en gerealiseerd heden elkaar niet zo veel ontlopen, aangezien beide gekenmerkt worden door een gevoel van échec. Het contrast tussen levensvreugde en vervreemding in de tweede groep wordt versterkt door een registerwisseling. In de passage waarin Jaap zich voorstelt dat hij wakker zou kunnen worden als Hans gaat Warmond ineens over op een vitalistische stijl. In het vitalisme speelt, net als in de romantiek, de idee van de onbedorven, instinctief levende 'sauvage' een rol, evenals de verheerlijking van een heroïsche dadendrang en een onbegrensd vreugdegevoel van kosmische zelfvergroting. Deze kenmerken vind je terug in de bedoelde passage. Jaap gedraagt zich als 'een biddende wilde in een oenwoud'. Stel dat hij wakker zou worden als Hans, daarna zou hij leven

als een orkaan! De stad $[\ldots]$ zou het dekor worden voor duizend en één verbijsterende belevenissen. $[\ldots]$ het avontuur zou lichtend exploderen; meteoren door zonnestelsels smijtend als confetti. Hij zou leven zoals hij nog nooit geleefd had. [...] Alles zou gebeuren. Alles en alles. Alles wat mogelijk en onmogelijk was. (p.23)

Deze passage wordt niet alleen gemarkeerd door een registerwisseling, maar ook. door het gebruik van een andere werkwoordstijd (zie bovenstaand citaat). De roman wordt hoofdzakelijk verteld in de onvoltooid verleden tijd, het zogenaamde episch praeteritum. De derde passage lijkt in eerste instantie futuraal qua werkwoordsvorm, maar is dat bij nader inzien niet. Het werkwoord zullen is hier veeleer in een modale functie gebruikt en drukt een niet-werkelijkheid of een wens uit. ${ }^{4}$ Jaap Viergever denkt na over een ander leven, dat een scherp contrast vormt met zijn huidige, op veiligheid gerichte, levenswijze. Het is niet voor niets dat Warmond in deze passage voor het imperfectum (zou), kiest, aangezien het de niet-werkelijkheid wat nadrukkelijker aangeeft dan de presensvorm. Deze vorm lijkt hier een mogelijkheid aan te geven, maar tegelijkertijd klinkt het onaannemelijke daarvan erin door. Mede door het gebruik van deze werkwoordvorm wordt hier een

\footnotetext{
4 ik volg hier de visie van de auteurs van de Algemene Nederlandse Spraakkunst: in sommige grammatica's wordt deze vorm tot het futurum gerekend. Aangezien deze combinatie van werkwoordsvormen zelden temporele betekenis heeft, worden zij in de ANS niet tot de categorie van de werkwoordstijden gerekend. Zie G. Geerts, W. Haeseryn, J. de Rooij, M.C. van den Toorn, Algemene Nederlandse Spraakkunst, Groningen/Leuven 1984: 453
} 
portret geschetst van Jaap als een burgerlijke man die niet uit zijn beperkingen durft te ontsnappen.

In de zesde passage gaat Warmond over op scenariostijl, in korte scènes wordt het vervolg, van de relatie met Eva beschreven als een middelmatige B-film. De filmmetafoor, die overigens ook in andere delen van het boek toegepast wordt, versterkt het vervreemdende gevoel van Hans:

alleen terug in zijn kamer zal hij het gevoel krijgen of hij ächter het filmdoek staat. In de zaal wordt gefloten. Hij is een hinderlijke schaduw achter de beelden. Hij wil niemand hinderen. Hij zal zich volgens scenario gedragen. Hij neemt zijn koffers en gaat de trap op naar zijn kamer. (p.153)

Ook hier is sprake van een afwijkende werkwoordstijd, namelijk het presens. Deze passage bevat de synopsis voor een filmscenario. Hierin visualiseert Hans het mogelijke verdere verloop van zijn relatie met Eva. Het presens heeft hier een levendig effect. Het suggereert dat de gebeurtenissen zich op dat moment ontrollen. Tegelijkertijd is er ook een ander effect werkzaam. Een film kun je meerdere keren draaien, waardoor het lijkt alsof de gebeurtenissen iedere keer weer nieuw zijn, ook al weet je inmiddels hoe het af zal lopen. Iedere keer opnieuw wordt het verhaal als het ware geactualiseerd door de film af te draaien. De presensvorm dient niet alleen. ter verlevendiging. Deze vorm kan ook een algehele waarheid uitdrukken die onafhankelijk is van de tijd, omdat ze geldt voor heden, verleden en toekomst. Deze laatste functie speelt ook een rol in de zesde passage. Het filmscenario vertelt in gecomprimeerde vorm het overbekende verhaal over de afloop van een relatie. De presensvorm drukt de tijdloosheid en het clichématige van deze situatie uit: zo gebeurde het vroeger, zo gebeurt het nu en dat zal in de toekomst niet anders zijn.

\section{Derde groep}

Ook in de derde groep is er sprake van een registerwisseling, Warmond gaat namelijk in de vierde en zevende passage over op een beschouwende stijl. De beide essayistisch aandoende passages, beschouwingen over angst, dood, liefde en tijd, plaatsen het verhaal aldus in een breder kader, waardoor het verhaal boven het particuliere niveau uitgetild wordt en een universele dimensie krijgt. Een genrevermenging als deze kan ertoe dienen om eenheid te brengen in wat verschilt: romanrealiteit en de in de essayistische delen aangeboden opvattingen komen dichter bij elkaar te liggen. De beschouwende passages lijken een toelichtend commentaar te zijn op de romangebeurtenissen of zijn de romangebeurtenissen illustraties bij de als universele waarheid gepresenteerde overdenkingen? Fictie en non-fictie komen hier heel dicht bij elkaar. ${ }^{5}$

5 zie Bart Vervaeck, 'Essay en vertelling in postmoderne tijden.' In: Nederiandse Letterkunde, jg. 6, nr. 4, november 2001:289-309 
Deze passages onderscheiden zich niet alleen door een andere lay-out (cursief gedrukt), maar ook door het gebruik van een andere werkwoordstijd. Het episch praeteritum van de roman wordt in deze twee essay-achtige passages vervangen door het presens, een vorm waarmee onder andere algemene waarheden uitgedrukt kunnen worden. Niet alleen door dit 'tijdloze' presens, maar ook door toon en inhoud vormen deze passages een stilistisch eiland in Warmonds roman. In tegenstelling tot de andere cursieve passages is het door de verandering van toon en inhoud niet meteen duidelijk wie er in de vierde passage aan het woord is: Hans of een externe verteller die op een metaniveau het verhaal van enige kanttekeningen voorziet. Bij nader inzien lijkt het me aannemelijk, dat Hans hier aan het woord is. Ten eerste omdat hij zowel vóór als na alle cursieve passages de focalisator is. Ten tweede omdat Hans in de andere cursieve passages, op de derde na, de centrale figuur is, ook in de zesde passage waarin hij op een filmische manier naar zichzelf kijkt. Ten derde omdat er in de zevende passage een zin staat waaruit blijkt, dat Hans de focalisator is:

Jacqueline moest dat hebben ingezien, die huilde niet. (p.192)

Tenslotte omdat de vierde en zevende passage niet alleen gemeenschappelijke thema's hebben, maar ook een gemeenschappelijke metafoor bevatten. De mens wordt hier niet gepresenteerd als een rationeel wezen, maar respectievelijk als 'een doodsbang en ellendig dier' (p.96) en als 'een jammerlijk dier' (p. 191). Deze beeldspraak benadrukt een duidelijk existentialistisch axioma, namelijk dat angst de basis van onze existentie is. In beide passages worden de grote existentiële thema's als angst, dood en liefde overdacht. Door de gebeurtenissen in een filosofische context te plaatsen wint het verhaal aan diepgang. Zowel het gebruik van het 'tijdloze' presens als van het categoriale lidwoord verleent de inhoud van de passages het karakter van een niet aan tijd gebonden waarheid, zoals blijkt uit de volgende twee voorbeelden:

Omdat een mens, die zich vertrouwd heeft proberen te maken met zijn eigen dood, van zijn eigen lichaam vervreemd is, zo zeer dat het zijn eigendom, zijn bezit niet meer is. (p. 97)

Alleen een mens ondergaat de dood als tegennatuurlijk. (p.192)

\section{Flashbacks en simultaneiteit}

Warmonds roman bevat een tiental flashbacks, die ik hier echter niet allemaal zal bespreken. Sommige flashbacks. geven achtergrondinformatie over het verleden, bijvoorbeeld over het ouderlijk milieu van Hans en over het leven van Esther Engelrijk. Hierdoor krijg je als lezer een beeld van het betreffende personage en 
van de manier waarop het op gebeurtenissen reageert. Andere flashbacks zijn herinneringen, die meer een vorm van retrospectie zijn ten aanzien van gebeurtenissen of gesprekken die kort daarvoor hebben plaatsgevonden. Het lijkt erop alsof het personage niet direct op het moment zelf op adequate wijze kan reageren, maar pas later begrijpt wat er is gebeurd. Er vindt een soort analyse achteraf plaats. Deze flashbacks duiden een zeker innerlijk isolement aan -de personages blijken een zelfde gebeurtenis op een andere manier te ervaren of te verwerken- en tegelijkertijd ook het verlangen dat isolement te doorbreken.

De flashbacks bevatten dus motieven die ook in de rest van de roman een rol spelen: deceptie, het geisoleerde bewustzijn en het verlangen het isolement op te heffen. Op die manier wordt de thematiek van de roman in meerdere lagen van het verhaal versterkt: niet alleen via de personages, maar ook via de tijdsstructuur (zowel in verhaalheden als in verhaalverleden). De scene in Biarritz waarin Hans het verloop van zijn relatie met Eva in een filmscenario voor zich ziet, zou je een flashforward kunnen noemen. Ook hierin wordt dezelfde thematiek aan de orde gesteld.

Paspoort voor niemandsland bevat een fout in de tijdsstructuur, die overigens geen consequenties heeft voor de rest van het verhaal. ${ }^{6}$ De avond na de overmeestering van Eva begint Hans koortsachtig aan de opdrachten voor zijn reclamebureau te werken. Tussendoor gaat hij niet uit. Op de avond van de vijfde dag krijgt hij hallucinaties: hij ziet overal brekend glas en vlammen om zich heen. Op de zesde dag van zijn retraite biedt Hans Eva zijn excuses aan voor de heftige vrijpartij. De volgende scène suggereert, dat die vrijpartij plaatsvond op de vijfde in plaats van op de eerste dag:

Op de zesde dag van zijn retraite was hij 's morgens wakker geworden op de grond voor het raam van zijn kamer. [...] Terwijl hij onder de douche stond, kwamen de herinneringen aan de vorige dag: het bezoek van Eva, het verhaal over de zelfmoord van Esther en zijn nu volkomen onverklaarbare reactie daarop. (p.134)

Een andere fictionele techniek is simultaneiteit, waarmee een samenvattend beeld gesuggereerd kan worden door gebeurtenissen te laten zien die zich tegelijkertijd maar op verschillende plaatsen afspelen. Een voorbeeld daarvan is de volgende passage uit La nausée:

Op ditzelfde moment varen er schepen op zee die weergalmen van muziek: in alle steden van Europa gaan de lichten aan; communisten en nazi's bevechten elkaar in de straten van Berlijn, werkelozen zwerven doelloos door New York, in warme kamers zitten vrouwen voor hun kaptafel en brengen mascara aan op hun oogharen. En ik loop door deze verlaten straat, en ieder schot dat wordt

6 op p.172 van de roman stat nog een slordigheidje, waar Renate Rubinstein in haar recensie van Paspoort wor niemandsland ook al op wees: niet Eric maar Flip is aan het woord. 
afgevuurd uit een raam in Neukölln, iedere in bloed gesmoorde snik van de gewonden die worden afgevoerd, ieder minutieus, zorgvuldig gebaar van de vrouwen die hun toilet maken, corresponderen met een pas die ik zet, met een klop van mijn hart.?

Deze techniek biedt ook de mogelijkheid om verschillende interpretaties te laten zien door de visies van diverse personages op een bepaalde situatie aan bod te laten komen. Mede daardoor kan het communicatieve isolement van het individu zichtbaar worden, aangezien de verschillende visies vaak niet met elkaar congrueren.

Ook in Paspoort voor niemandsland komen enkele simultane passages voor. In de periode dat De la Rive na een woordenwisseling met Hans de Olympus-bar verlaat en daarna in een monologue intérieur onder andere zijn afkeer van erotiek ventileert (hoofdstuk V en VI), ontmoet Hans in de Olympus voor het eerst Eva (hoofdstuk VII). Simultaneïteit is ook te vinden in hoofdstuk XII, XIII en XIV. Als Hans na het bezoek van Esther door de schoonmoeder van zijn vriend wordt weggestuurd, verlaat Esther een café om een hotel te zocken waar ze zelfmoord kan plegen. Op het moment dat Hans thuis bij Eva ontdekt, dat zij zijn paspoort is voor het 'land der levenden', pleegt Esther zelfmoord in hotel 'Arizona'. In al deze passages is simultaneïteit een fictionele strategie om de twee kanten te laten zien van de keuzeproblematiek die in deze roman centraal staat: anti-lichamelijkheid versus erotiek (De la Rive-Hans), vriendschap versus erotiek (Bert-Hans) en tenslotte leven versus dood (Hans-Esther). Deze aspecten worden in de komende twee hoofdstukken uitgewerkt.

\section{Ironie}

Diverse personages uit Paspoort voor niemandsland worden gekenmerkt door een ironische kijk op allerlei situaties. Volgens Sartre is ironie net als de mauvaise foi een negatief gegeven, omdat ze de absentie of nietsheid onthult. Wat gezegd wordt, is niet wat bedoeld wordt. Wat bevestigd wordt, wordt ontkend. ${ }^{8}$ In haar boek Irony's Edge (1995) bespreekt Linda Hutcheon diverse opvattingen over ironie." Zo zou ironie het enige middel zijn waarmee de afstandelijke intellectueel iets van zijn gevoelens laat zien of een middel waarmee vijandigheid en emotionele betrokkenheid gemaskeerd worden. Ironie reduceren tot een omkering van de letterlijke betekenis leidt tot een simplificatie van de ironische betekenis, aldus Hutcheon. Ironie is in haar visie geen eenvoudige vervanging van datgene wat ongezegd blijft (de ironische betekenis) door zijn tegendeel, datgene wat wel gezegd wordt (de letterlijke betekenis). De letterlijke betekenis wordt vaak ten onrechte als minder belangrijk terzijde geschoven.

7 Jean-Paul Sartre, Walging. Amsterdam $1990^{11}: 81$

8 zie Daniel Berthold-Bond, 'Irony.' In: Gordon 1999: 218-220

9 Linda Hutcheon, Irony's Edge. The Theory and Politics of Irony. London/New York 1995 
In plaats van dit off/of-model stelt zij het inclusieve en simultane model voor. Net als woordspelingen heeft ironie een zekere simultaneiteit. Ze is meervoudig, daarom hoef je de letterlijke betekenis niet af te wijzen ten faveure van de ironische of zogenaamd werkelijke betekenis van de uiting. De ironische betekenis ontstaat niet eenvoudig door een binaire keuze, maar door een inclusieve. Het gezegde en het ongezegde werken samen om de ironische betekenis te creëren. De ironische betekenis komt als derde component te voorschijn door de snelle en dynamische wisseling tussen zowel het gezegde als het ongezegde. Er is niet zozeer sprake van oppositie als wel van incongruentie tussen het gewone en het onverwachte. Ironie voegt niet alleen maar complexiteit of variatie toe aan een gesprek, ze drukt ook een houding of een gevoel uit én ze roept emoties op. Het emotionele scala loopt, zowel bij de spreker als bij de toehoorder, van geamuseerdheid tot ergernis, van plezier tot pijn.

In Paspoort voor niemandsland bestaat er bij diverse personages een incongruentie tussen feitelijkheid en verlangen. Dit leidt mijns inziens alleen tot maumaise foi als de werkelijkheid wordt afgewezen terwijl het verlangde op de voorgrond wordt geplaatst. Dat is echter niet het geval. De personages hebben over het algemeen oog voor de realiteit. Het is juist de dynamiek tussen beide polen die een ironische houding creëert Op die manier kan de pijn, die door de incongruentie wordt veroorzaakt, worden verzacht of op zijn minst worden gerelativeerd. In de volgende twee hoofstukken kom dit nader aan de orde.

\section{Conclusie}

Warmond maakt in haar roman Paspoort voor niemandsland gebruik: van een interessant scala aan technieken: perspectivische technieken, programmatische namen, lay-out (cursieve passages), genrevermenging, registerwisselingen, afwijkende werkwoordstijden als markeerders, flashbacks, simultaneiteit en ironie. Deze technieken kunnen tot de formele/literaire component van het literaire existentialisme gerekend worden, omdat ze de existentialistische problematiek mede zichtbaar maken. 


\section{EXISTENTIALISTISCH PASPOORT 1}

In het vorige hoofdstuk stonden enkele technische aspecten centraal. Dit hoofdstuk. zal vooral de existentialistische thematiek in Paspoort wor niemandsland aan de orde stellen aan de hand van de volgende aspecten: de grenssituatie en de ander als katalysator. In het volgende hoofdstuk worden aspecten als engagement, gesloten ruimtes, geseculariseerde invulling van christelijke begrippen, het classificatieprocédé en registerwisselingen besproken.

\section{Grenssituatie}

Het bestaan van Hans Erkelens komt onder grote druk te staan, als blijkt dat hij net als zijn inmiddels overleden vader, ooms en broer aan keelkanker lijdt. De nache vóór hij naar de chirurg moet, komt hij in een existentiële crisis terecht, waarin hij zijn leven en vooral zijn echecs hardop overdenkt. Hij wordt overmand door haat en woede:

Hij haatte alles en iedereen, mensen en voorwerpen, alles wat buiten hem om zou blijven bestaan alsof hij er zelfs nooit geweest was. Hij voelde een aandrift om de hele kamer kort en klein te slaan, een redeloze vernietigingsdrang, een machteloze drang naar agressie. (p. 18)

Hoewel Warmond er redelijk in slaagt om Hans als romanfiguur tot leven te wekken, is hij tegelijkertijd ook een exemplárisch mens, een soort Elckerlije die worstelt met zijn eindigheid. Dit exemplarische karakter wordt versterkt door het feit dat kanker al in het tweede hoofdstuk gebruikt wordt als metafoor voor de algemene vergankelijkheid:

Cancer is a disease of time... time is a cancer in the human soul... (p. 18)

Kanker tast niet alleen het lichaam, maar het hele bestaan aan, aangezien we daardoor geconfronteerd worden met de dood. Ons leven komt onder druk te staan, omdat het niet-zijnde zich openbaart in ons temporele bestaan, waardoor gevoelens als angst en paniek naar boven komen. Niet alleen ziekte, maar ook andere situaties, zoals oorlog, kunnen het bestaan op die manier heftig onder druk zetten. Bij Hans fungeren zelfs beide factoren als een soort pressurecooker:

In de oorlog was het begonnen: het onbewuste gevecht met de tijd. Niet om een stap vóór te blijven, nee, de panische angst plotseling te kunnen sterven en dan iets gemist te hebben. (p. 19) 
Hans komt voor de taak te staan opnieuw zin te geven aan zijn leven, wat onder meer blijkt uit de volgende passage, die een allusie bevat op het Lazarus-verhaal:

Hij had zichzelf zien sterven en begraven worden. Nu moest hij het lijk overeind zetten, het ondersteunen, helpen lopen en weer leren leven. (p. 9)

De tijdbeleving komt extra onder druk te staan, doordat een al dan niet theologisch concept van een hiernamaals geen rol speelt. Het Nieuwe Testament bijvoorbeeld plaatst ziekte in een ander perspectief, onder andere in het elfde hoofdstuk van het Johannes-evangelie, dat verhaalt van de dood en opstanding van Lazarus. In Joh. 11: 4 zegt Jezus: 'Deze ziekte voert niet tot de dood.' In zijn verhandeling Over de vertwijfeling schriff Sören Kierkegaard over deze passage:

niet omdat Lazarus uit de doden is opgewekt, niet daarom kan men zeggen dat déze ziekte niet tot de dood voert; maar omdat Hij er is, daarom voert deze ziekte niet tot de dood.'

In tegenstelling tot existentie-filosofen als Kierkegaard en Jaspers, die (uiteindelijk) uitkomen bij het christendom, nemen de Franse existentialisten een atheistische positie in, waarin het volle accent op dit ene leven hier en nu ligt. Het theïsme, dat ervan uitgaat dat alles door God geschapen is, staat in hun visie haaks op de idee van de menselijke vrijheid, omdat het de mens herleidt tot een maakding. Ze hebben ook nog een ander bezwaar tegen het thë̈sme: wie meent de absolute maatstaf in handen te hebben waraan alles getoetst moet worden, heeft geen behoefte meer om nog verder te zoeken. ${ }^{2}$ In het existentialisme wordt de contingentie van het bestaan, het besef op de aarde geworpen te zijn, benadrukt. De mens creëert hier en nu zijin eigen essentie, die niet vooraf gegeven is, zoals in een theologische opvatting vaak wordt aangenomen. Dit betekent aan de ene kant dat de existentialistische mens een grote mate van vrijheid heeft, omdat hij het leven ervaart als een waaier van mogelijkheden, aan de andere kant kan dit ook beklemmend werken door het besef zich niet voldoende verwerkelijkt te hebben. Zijn zelfontwerp is dan slechts schetsmatig gebleven of vertoont open plekken. Dit speelt ook bij de hoofdfiguur uit Warmonds roman een rol:

de panische angst plotseling te kunnen sterven en dan iets gemist te hebben. lets? Alles! En dan de haast om zoveel mogelijk te doen, zoveel mogelijk beleefd te hebben 'voor het te laat was'. Voor het te laat was? Het was altijd te laat ... p. 19)

1 Sören Kierkegaard, Over de verturifeling. De ziekte tot de dood. Utrecht/Antwerpen 1963:21

2 zie: A. Dondeyne, "Beschouwingen bij het atheistisch existentialisme.' In: Tijdschrift voor philosophie. Leuven 1951, nr. 13, p. 1-41 
Hans Erkelens heeft zich voorbereid op de dood, maar na het gunstige bericht van de chirurg moet hij zich voorbereiden op het leven. Deze specialist is als het ware de verpersoonlijking van de vitaliteit:

het verrukte gezicht van een levensgenieter. Groot, rood, glanzend. Met een klein, wellustig, bijna vrouwelijk mondje onder een vlezige neus. En daarboven de vergenoegd-halfdichtgeknepen ogen, stralend van een soort rondborstige sensualiteit, die bijna aanstekelijk werkte. Er lag achter dat gezicht een hilariteit op de loer. Een Rabelaisiaanse bulderlach, die op de minste provocatie zou kunnen losbarsten, bevrijdend, geruststellend, als een onweer na een broeierig-hete augustusdag. [...] Wanneer de diagnose meeviel, zoals in zijn eigen. geval, deed deze boerse Pan een leven cadeau [...] (p. 11)

Dat levenslustige wordt geaccentueerd door de arts te verbinden met vitalistische beelden uit een mythologische en literaire context. De 'Rabelaisiaanse' bulderlach is een verwijzing naar de vrolijke, rondborstige levensgenieters Gargantua en zijn zoon Pantagruel, creaties van de zestiende-eeuwse auteur François Rabelais. Het is interessant dat de chirurg vergeleken wordt met Pan, de levenslustige en vitale herdersgod die door zijn geschreeuw eenzame reizigers ineens schrik aanjaagt, waardoor de naar hem vernoemde paniek ontstaat. De arts verenigt namelijk beide aspecten in zich: een vitalistische persoonlijkheid, die Hans een panische angst bezorgt, in dit geval door hem het leven terug te geven.

Die panische angst, aangewakkerd door een verhevigd vergankelijkheidsbesef, neemt bezit van zijn hele lichaam en uit zich in benauwdheid, duizeligheid en braken. Hij wordt volledig op zichzelf teruggeworpen:

Hij voelde zich verder van die anderen verwijderd dan ooit, alsof ze niet werkelijk bestonden, alsof hij de enige overlevende was na een ramp, die alle leven van de hele aarde had weggevaagd en alsof die anderen alleen nog in zijn herinnering bleven voortbestaan. (p. 193)

Die aanvallen van doodsangst depersonaliseren hem niet alleen 'tot de rand van de hysterie' (p. 93), maar gaan ook samen met een. veranderde tijdsbeleving:

een lichamelijk geworden gevoel van tijdnood, dat hem momenten van wurgende benauwdheid bezorgd had (p. 13-14)

Angst en verantwoordelijkheid nemen in het existentialisme een belangrijke plaats in, zij zijn integrerende bestanddelen van het handelen. De angst komt bij de mens voort uit het besef vrij te zijn en steeds weer te moeten beslissen over zijn eigen existentie. Sartre beweert zelfs dat de mens angst is: de mens die zich er rekenschap van geeft dat hij degene is die hij verkiest te zijn, kan niet ontkomen aan een gevoel 
van totale en vergaande verantwoordelijkheid ten aanzien van zichzelf én van anderen. ${ }^{3}$ Voor de existentialist heeft het leven geen zin a priori:

Voordat u leeft is het leven niets, maar het is aan u er een zin aan te geven en waarde is niets anders dan de zin die u kiest. ${ }^{4}$

De mens heeft geen andere wetgever dan zichzelf, hij kan daardoor geen verantwoordelijkheid afwentelen op god, maatschappij of opvoeding. Hij moet in de verlatenheid over zichzelf beslissen en dat kan alleen in een rechtstreekse confrontatie met zichzelf. Onderworpen aan een alternative perpétuelle creëert de mens op die manier zijn eigen levensontwerp. Afgezien van de vraag of er sprake is van absolute of geconditioneerde vrijheid, kiezen gaat gepaard met angst. Er zijn weliswaar veel mensen die beweren geen angst te voelen, aldus Sartre, maar dat is slechts een vlucht. Angst is voor degenen die de verantwoordelijkheid op zich. nemen de voorwaarde bij uitstek voor hun handelen, want daardoor moeten zij een groot aantal mogelijkheden onder ogen zien. Wanneer ze één daarvan kięen, zijn ze zich ervan bewust dat die mogelijkheid alleen als keuze waarde heeft. Hans Erkelens beseft dat alle mogelijkheden voor hem open liggen, maar hij schrikt terug voor de verantwoordelijkheid die welke keuze dan ook impliceert:

toen ik in het ziekenhuis lag, na die operatie, en dus wist dat ik gewoon verder zou leven, toen wist ik het nog allemaal; wat ik met dat leven doen zou. Ik had het gevoel alsof ik opnieuw kon beginnen, met een schone lei. Alsof ik weer alle mogelijkheden had. Maar die zekerheid zakte later weg: ik wist niet meer wélke mogelijkheden dat dan wel geweest moesten zijn, waar ik zo rotsvast in geloofd had. Ik was verdomd blij dat ik nog leefde, maar verder wist ik het niet meer. Ik wist niet meer wat ik met die tijd, die ik teruggekregen had, zou moeten doen. En wanneer ik me dat probeerde te herinneren, kreeg ik een paniekgevoel, dat ik niet beschrijven kan, maar wat je overvalt als je iets vergeten bent wat van essentiëel belang is en wat je maar niet te binnen wil schieten. [...] Of is het soms zo, dat je je wel zou kunnen herinneren wat je vergeten zegt te zijn, maar het eigenlijk niet wil? (p. 108)

Als hij in Parijs de balans opmaakt van zijn nieuwe leven, wordt hij overvallen door wanhoop, omdat ook dit nieuwe leven uitgelopen is op een echec. Als hij zichzelf een cijfer moest geven, dan werd dat een nul, het enige telwoord dat het ontbreken van een hoeveelheid uitdrukt:

Terwijl hij daar zat leek het hem toe alsof hij zich nu pas volledig bewust werd dat zijn nieuwe bestaan een farce geweest was, een grap zonder pointe. Niet

3 Jean-Paul Sartre, Over het existentialisme. Utrecht 1985: 17

4 Sartre 1985:39 
eens één groot echec, maar duizend kleine mislukkingen. Hij had gefaald tot in de details. [...] Haastig dronk hij zijn koffie, rekende af en vluchtte, struikelend van woede om zijn nederlaag, de straat uit. (p. 156)

Als ik op dit moment stierf, zou ik mijn leven moeten kunnen berekenen, als in cijfers. Of is er maar één cijfer: nul, zéro, nihil? [...] Hij liet zijn hoofd opzij kantelen, sloot zijn ogen en luisterde gelaten naar het opdringerige tikken van zijn horloge, vlak naast zijn oor: zéro-zé-ro-zé-ro-zé-ro-zé-ro ....(p. 159-160)

Angst, wanhoop en deceptie zijn gevoelens die vaak figureren in een existentialistische context. Dat geldt ook voor de walging, die door Camus omschreven wordt als het onbehagen dat ons overvalt wanneer we de onmenselijkheid van de mens zien. ${ }^{5}$ Tegelijkertijd realiseren we ons dat de objecten voor en op zichzelf bestaan en het zonder de mens en zijn classificaties kunnen stellen. De walging is, evenals de angst, een uiting van vervreemding, maar dan nog op pre-reflexief niveau. $\mathrm{Zij}$ wordt gekenmerkt door twee effecten: depersonalisatie of verdingelijking van de mens aan de ene kant en vitalisering of personificatie van objecten aan de andere kant. Beide effecten zijn aan te wijzen in Warmonds roman, zoals onder andere blijkt uit de volgende citaten, waarin de 'hand' een opvallende plaats inneemt:

Toen hij [= De la Rive] eindelijk zat, legde hij zijn hand, alsof het een zelfstandig voorwerp was, op het tafeltje tussen hen in, met het gebaar waarmee een juwelier het kostbaarste stuk uit zijn winkel op de toonbank zou leggen. [...] Die hand scheen, zoals eigenlijk alles aan hem, een zelfstandig bestaan te leiden en tegelijkertijd toch onafscheidelijk bij de rest te horen; in het geheel passend als een onderdeeltije van een mozaïek. (p. 34)

Er was geen gezicht denkbaar waar ze [= Esther, voor de spiegel staand] zoveel weerzin voor voelde. Ze bracht haar arm omhoog en zag in de spiegel een kleine, sierlijke hand, die als de hand van een blinde met de vingertoppen langs de huid tastte [...] Ze keek in de spiegel alsof die hand door een ander bestuurd werd. Alsof het verrassend zou zijn, te zien wat er verder zou gebeuren. Rond de hals bleef de hand liggen: een kalme schroef van vlees. (p. 101)

Hij sloeg zijn ogen neer en keek naar het geruite tafelkleedje. Zijn hand lag precies vijf blokken van de hare vandaan. Scheef, hortend, als een gewond reptiel, kroop die hand die vijf blokken langs en schoof zich over de hare. Parende spinnen. Maar hij nam zijn hand niet weg. [...] De binnenstromende koude nachtlucht deed het geblokte kleedje rillerig opwaaien. (p. 147-148)

5 zie: Albert Camus, De myte uan Sisyfus. Een essay over het absurde. Amsterdam 1975:113 
De vervreemding, de ervaring van het absurde, waar de walging een pre-reflexieve uitingsvorm van is, ontstaat als de mens een breuk ervaart tussen zichzelf en de wereld. Het absurde ontstaat uit de confrontatie tussen het menselijke verlangen naar eenheid en de als redeloos en versnipperd ervaren wereld, aldus Camus. Hij brengt een fasering aan in de absurditeitservaring: het begint met een gevoel van verveling, vervolgens worden objecten als vreemd ervaren en tenslotte ervaar je jezelf of de ander als een vreemde:

Met de eenvoudige 'verveling' begint alles. Hij maakt deel uit van de tijd en aan de afschuw die hem bij deze constatering bevalt, herkent hij de tijd als zijn ergste vijand. Een trede lager stuiten we op de vreemdheid: we ontdekken dat de wereld 'ondoorzichtig' is, in een flits zien we hoe vreemd en onoverwinnelijk een steen voor ons is en hoezeer de natuur of een landschap ons bestaan kunnen negeren. De wereld ontsnapt ons, omdat zij weer zichzelf wordt. Deze ondoorzichtigheid en deze vreemdheid van de wereld, dat is het absurde. Het onbehagen dat ons overvalt wanneer we de onmenselijkheid van de mens zien, deze walging, ook dat is het absurde. Het absurde is ook de vreemdeling die ons soms tegemoet komt in een spiegel of de vertrouwde broer bij wie wij ons toch niet op ons gemak voelen, die wij weerzien wanneer we foto's van onszelf bekijken. ${ }^{6}$

Volgens het ambiguitteitsmodel van Merleau-Ponty is er wel degelijk een verzoening mogelijk tussen mens en wereld, waartoe ook de ander behoort. Vervreemding ontstaat juist, omdat de verwachte solidariteit en verbondenheid uitblijven. De vervreemding, waaraan dus een verlangen naar gemeenschappelijkheid ten grondslag ligt, wordt in Paspoort voor niemandsland opvallend vaak opgeroepen door middel van de film- en scenariometafoor. Door gebruik te maken van de filmische techniek van het in- en uitzoomen wordt het verschil tussen verlangen en realiteit zichtbaar. Als Hans probeert Eva zijn liefde te verklaren, ziet hij in een sensuele close-up zijn romantisch verlangen geprojecteerd. De werkelijkheid blijkt echter minder rooskleurig:

Ik hou van je, zegt de minnaar op het witte doek. Eén keer maar zegt hij dat en meteen komt al langzaam, groter, steeds groter wordend, de zachte rode mond van zijn tegenspeelster op de zaal toe. Kijk hoe hij mij gaat kussen. Een mond waarop je je hoofd zou kunnen neerleggen, om te slapen. [...] 'Liefje,' zei hij. De filmmond week achteruit, werd kleiner, smaller, minder rood, gieriger, spottend, werd de mond van Eva. (p. 147)

Hans ervaart zijn aflopende verhouding met Eva in filmische beelden, waaruit blijkt dat hij de situatie al met enige afstand in ogenschouw neemt. In plaats van een

6 zie: Albert Camus, De myte uan Sisyfus. Een essay over het absurde. Amsterdam 1975: 21 
klassiek romantische love-story met sensuele close-ups ontwikkelt de relatie zich van een Amerikaanse film-honeymoon tot een nog slechtere B-film:

de aardigheid van het samen zijn en het samen alleen zijn is er eigenlijk al af, maar de partners blijven geïnteresseerd in de lens kijken, zolang de opnamen duren. (p. 151)

Wat had hij in Parijs ook alweer gedacht over een scenario? Het was nog lang niet uit. Wat een formidabele rotfilm! (p. 161)

Andere filmachtige technieken zijn bijvoorbeeld de fade-out en overblending. Een voorbeeld van de eerste techniek is te vinden aan het eind van de passage waarin Hans droomt over het einde van zijn vriendschap met Bert:

Zijn stem ging in het gebulder van de wind verloren en de divan met Bert erop begon langzaam uit het gezicht te verdwijnen, wegzeilend, vervagend als een filmbeeld. (p.66)

Overblending is een term die Hans gebruikt als hij aan zijn geliefde uitlegt dat er twee Eva's zijn: de fantasie-Eva en de echte Eva:

[...] jullie moeten niet door elkaar heen gaan lopen. 'Overblending' heet dat geloof ik in de filmwereld. Dat maakt me onrustig, onzeker [...] (p. 142),

Deze techniek is ook te vinden in hoofdstuk XXI, warin een cursieve scenario-scène overgaat in de romanwerkelijkheid. Beide sferen raken elkaar: de romanwerkelijkheid krijgt iets van een filmkarakter, terwijl het scenario werkelijkheid lijkt te worden. Dit heeft een vervreemdend effect, niet alleen op het romanpersonage, maar ook op de lezer:

[...] Hij zal zich volgens scenario gedragen. Hij neemt zijn koffers en gaat de trap op naar zijn kamer.

Hij ging de trap op naar zijn kamer, waar hij uitgeput op de rand van het bed ging zitten. (p. 153)

In andere gevallen echter accentueert de scenariometafoor vooral het contrast tussen wens en werkelijkheid, bijvoorbeeld in de passage waarin de hoofdpersoon zich voorstelt dat hij voor de rechtbank staat wegens moord op Kasper Wever, de echtgenoot van Eva. In werkelijkheid durft hij niets te ondernemen.

Evenals Sartre in La nausé maakt Warmond gebruik van de spiegelmetafoor om de vervreemding op te roepen, soms in combinatie met de filmmetafoor: 
Door de openstaande deur keek hij in een grote staande spiegel. Die spiegel weerkaatste een lege, roodpluchen leunstoel. Hij probeerde het beeld grappig te vinden door te denken dat een close-up van die stoel het prachtig zou doen in een derderangs-griezelfilm. Met in de hoofdrol Hans Erkelens, die jaren na zijn dood, nog steeds in een spiegel nauwlettend naar zijn eigen schim zit te kijken. (p. 157)

Het spiegelmotief in Warmonds roman vertoont overeenkomsten met de wijze waarop dit motief in haar dichtwerk figureert. Een belangrijk thema is de transformatie van illusies in desillusies, warvan de bewustwording tot stand komt via de blik in de spiegel. Het verwachtingsvolle verleden botst met het teleurstellende heden. De spiegel is een plaats van confrontatie: het lyrisch subject en het romanpersonage zijn op zichzelf gefocust door middel van een vernauwde en benauwende blik. Deze zelfreflectie gaat vaak gepaard met angst, verwarring, teleurstelling, zelfspot, weerzin en zelfs nausée. De spiegelmetafoor domineert in de hoofdstukken waarin Esther en Hans de balans opmaken van hun leven en doordrongen zijn van hun echec.

In hoofdstuk 11 blikt Esther bij Hans op zijn kamer terug op haar leven. De dag daarvoor heeft ze haar vroegere geliefde Karin ontmoet. Ineens beseft ze hoe lang dat geleden was en hoeveel tijd ze intussen vergooid heeft, al zou ze niet weten wat ze anders met die tijd had moeten doen. In de spiegel ziet ze eruit als een mooie, aantrekkelijke vrouw, dat beeld correspondeert echter niet met hoe ze zich voelt, namelijk 'oud, op en fanée'. Ze acht haar leven mislukt:

'Kijk,' zei ze, in het spiegeltje van de poederdoos wijzend, 'dat smoel daar: als ik niet zo moe was, zou ik daar uren om kunnen grinniken. Ik ben misselijk van mezelf. Het is om te kotsen tot de tranen over je gezicht lopen. Ik walg van mezelf en ik veracht mezelf. (p. 74)

Ook Hans wordt via een blik in de spiegel geconfronteerd met zijn echec:

Wat hij daar voor zich in de spiegel zag was een karikatuur van alles wat hij ooit had willen zijn of worden. Zijn bruinverbrande gezicht was grauw van vermoeidheid. Hij was armoedig en nietig, het prototype van iemand, die het nét niet gehaald heeft in de wereld. Een onmiskenbaar onbeduidende figuur $[\ldots]$ (p. 154)

Er kan soms sprake zijn van een vervreemdende dubbele identiteit: het romanpersonage herkent zichzelf in de spiegel, maar zijn spiegelbeeld ervaart hij tegelijkertijd als dat van iemand anders. Dat ervoer Hans al in zijn puberteit, toen hij experimenteerde met het creëren van een macho-image, en af en toe ineens de belachelijkheid daarvan besefte: 
Een puber met puistjes, die avond aan avond voor de spiegel probeerde zijn kaak vooruit te steken en een wilskrachtige trek om zijn mond te dwingen. Zijn ondertanden voor zijn boventanden brengend, keek hij dan naar zijn spiegelbeeld. Hij zag eruit alsof hij een kaakontsteking had en dan overviel hem soms ineens het gevoel alsof er iemand achter hem stond, die meewarig het hoofd schudde. (p. 165)

Aangezien de spiegel de actieradius van het oog vergroot, kun je jezelf zien zoals een ander je ziet. Soms kan dit uitlopen op een tweespalt tussen zelfbeeld en spiegelbeeld, zoals blijkt uit het volgende romanfragment, waarin Hans zichzelf van buitenaf, als een vreemde, observeert in de spiegelkast op zijn hotelkamer in Parijs:

een iets te kleine, magere jongeman, die in de keuze van zijn kleding alle fouten gemaakt had, die te kleine mannen allemáál maken: de te lichte tint grijs van zijn pak, de te scherpe vouw in zijn broek en het blinkend-witte overhemd met de net iets te opzichtige das. Zijn haar was te lang, te kwasi-artistiek. Hij begreep niet, dat Eva hem niet zag, zoals hij zichzelf daar zag staan. (p. 153)

Via een blik in de spiegel krijgt Hans niet alleen een andere kijk op zichzelf, maar ook op zijn relatie met Eva. Hun reflectie in een caféspiegel suggereert een romantische verhouding, waarin het lijkt of ze een innige band met elkaar hebben. In werkelijkheid spelen ze een rol, als in een film. Hier vindt een opmerkelijke omkering plaats van spiegelbeeld en werkelijkheid: het spiegelbeeld lijkt realiteit, terwijl de realiteit een filmische sensatie oproept:

Soms, in een spiegel in zo'n bar, zag hij hun twee gezichten, naast elkaar, alsof ze iets met elkaar te maken hadden. Dan dacht hij: in die spiegel zijn we reëler dan in werkelijkheid. We spelen allebei een rol die ons niet ligt en we doen dat allebei bovendien zonder veel overtuiging en zonder ons in te spannen om er zelfs maar iets van te maken. $\mathrm{Z}_{\mathrm{ij}}$ speelt dat ze met mij een relatie heeft, die verder gaat dan voor een paar uur in bed en ik had alleen maar een plan met mijn leven waarin ik haar op een bepaalde plaats wilde invoegen, als een ontbrekend stukje in een legkaart. Ik doe net alsof het nergens anders om gaat dan om de filmopname van 'een week vakantie'. (p. 151)

\section{De ander als katalysator}

De 'ander' is in existentialistische literatuur het centrale onderwerp. De aanwezigheid van de ander dwingt het existentialistische personage tot stellingname en het maken van keuzes. Door de confrontatie met de ander moet het personage op zoek gaan naar zijn eigen authenticiteit, naar wat hij zélf als waardevol ervaart, zonder daarin gestuurd te worden door wat anderen daarvan vinden. In de roman Paspoort 
voor niemandsland zijn het vooral Bert en Eva die het leven van Hans het meest onder druk zetten.

Dialogen vormen in deze roman een belangrijk structuurelement: ideeën over existentiële onderwerpen als integriteit, liefde, erotiek, echec en dood worden via deze vorm aan de lezer gepresenteerd. Het opmerkelijke is, dat de dialogen vaak een monologisch karakter hebben: degene tegen wie wordt gesproken geeft over het algemeen weinig weerwoord. Het zijn in feite dialogen met zichzelf. Dit geldt voor de gesprekken van Bert over integriteit en liefde, van Esther over haar echecs en verlangen naar de dood en voor de liefdesbetuiging van Hans aan Eva. Deze monologische dialogen leggen een schrijnende realiteit bloot: zowel de spreker als de toegesprokene wordt op zichzelf teruggeworpen, juist omdat het echte contact waarnaar verlangd wordt uitblijft.

\section{De projecterende blik}

De gesprekken met Bert worden gedomineerd door twee motieven: integriteit als kunstenaar en waarachtige menselijkheid. Zijn leermeester vindt dat Hans zijn talent verknipt in een aantal vaardigheidjes door te werken voor 'die reclamekerels', niet omdat het niet goed is wat hij daar maakt, maar omdat hij Hans liever ziet schilderen. $\mathrm{Hij}$ is niet alleen in hem teleurgesteld, hij voelt ook dat er een verwijdering heeft plaatsgevonden tussen hen:

Terwijl ik toch alles voor zijn bestwil gedaan heb. Ik erger me ook te pletter aan. hem de laatste tijd. Aan zijn manier van leven. lk heb hem toch niet voor niets helemaal opgevoed; ik heb toch geprobeerd een beetje een mens van hem te maken. En wat hij nu doet is een beschamende aaneenschakeling van kleine succesjes. Hij is geslaagd, te makkelijk geslaagd, naar mijn smaak. En waarin dan nog helemaal? Dat moet op de duur toch vastlopen in een zinloze bedrijvigheid, waar alleen nog maar verkleinwoordjes bij passen: succesjes, centjes verdienen en vrouwtjes. [...] Wat is er dan in godsnaam? Hij vertrouwt me niet meer, al kan ik niet bewijzen, waar zich dat door uit. Maar hij vertelt me de dingen die hij doet en die hem bezighouden niet meer op dezelfde manier als vroeger. Hij vertelt alles nu als anekdotes, alsof hij een oude oom bezig moet houden; alsof hij een praatje moet maken uit beleefdheid. (p. 80-81)

Bovendien vindt hij dat zijn vriend zich encanailleert door zich op te houden met de quasi-artistieke bende die de Olympus frequenteert. Alles wat daar komt is volgens hem 'artistiek, sociaal en menselijk wrakhout'.

Zijn romantisch kunstenaarschapsideaal botst met de realiteitszin van Hans, die in de reclame is gaan werken om te kunnen eten. Maar niet alleen daarom. Hans gelooft niet in zijn kunstenaarschap: 
Op de academie en nog een tijdje daarna had hij daarin geloofd. Maar wat was hij voor een schilder geworden? Hij had wel een beetje talent, maar voor de rest was hij voornamelijk 'handig'. Hij maakte op een handige manier 'aardige schilderijtjes' en 'redelijke tekeningen'. Toen hij dat eenmaal had ingezien, had hij die handigheid maar benut door opdrachten voor een reclamebureau aan te nemen. Dan verdiende hij tenminste zijn brood. (p. 9)

Eva heeft hem gevraagd haar portret te schilderen, omdat ze getroffen zegt te zijn door zijn schilderij van een dood kindje. Is dit schilderij emblematisch voor zijn kunstenaarschap, dat zich niet meer ontwikkelt of verwijst het vooruit naar hun relatie, die uiteindelijk niet levensvatbaar blijkt te zijn?

Als Hans hem vertelt over Eva's vraag, barst Bert in een buitenproportioneel heftige tirade los. Buitenproportioneel, omdat Hans aangegeven heeft dat hij niet op Eva's verzoek in zal gaan. Bert zegt hem de vriendschap op, omdat hij zijn talent vercommercialiseert en er een handelsreizigersmentaliteit op na houdt. Hij schetst hem het volgende toekomstperspectief, waarin en passant ook de communis opinio over kunstschilders naar voren komt:

Doe het maar! Misschien heeft ze wel vriendinnen, die ook een portret willen hobben, het kan jou immors toch niec scholen wie on wat? Natuurlijk hoof eo vriendinnen! En die vriendinnen hebben dan ook mannen, die natuurlijk ook wel eens jarig zijn en dan zo'n portret zogenaamd gevraagd hebben als cadeautje. Om je rot te lachen! Die worstkoning, waar ze mee getrouwd is, die zou nog niet dóód gezien willen worden naast een schilderij. Zelfs niet als het een goed schilderij zou zijn. Ik bedoel: iets beters dan die bonbondoosprenten die jij wel zal gaan maken, tegen de tijd dat je in de mode geraakt bent in die kringen. Zo'n vent als Wever vindt schilders grote idioten, uitvreters, kerels die liever op een fatsoenlijke manier aan de kost moeten zien te komen, in plaats van zich te laten onderhouden van zijn belastingcenten, zoals hij uit zijn kwalijke ochtendblad geleerd heeft. Een schilderij is voor hem op zijn gunstigst een plaatje en voor plaatjes interesseert hij zich alleen als ze bruikbaar zijn als etiketten op zijn worstblikjes. Missçien mag jẹ dạt nog wel eens voor hem doen,' besloot hij giftig, 'etiketten ontwerpen voor worstblikjes! Begrijp je me nu? Ik wou dat ik tien jaar geleden de penselen uit je poten geslagen had! Wórstblikjes! (p. 60)

Het existentialistische personage ondergaat de druk van de ander vooral via diens blik, die angst, schuld, schaamte of walging op kan roepen. Het gevolg van zo'n confrontatie is vaak de ervaring onder de blik van de ander tot een ding gemaakt te worden. Het is de vraag of Bert wel in Hans als individu geïnteresseerd is, aangezien hij zijn vriend laat vallen op het moment dat deze niet voldoet aan zijn normen en 
waarden. Bert ziet zichzelf in hem terug en wil hem behoeden voor de fouten die hij in zijn jeugd heeft gemaakt:

Ik zeg dat niet uit bemoeizucht, heus niet. Maar ik weet te goed waar ik over praat. Toen ik zo oud was als jij [...] toen leefde ik net zo. En als ik Jacqueline niet ontmoet had dan zou ik nu een ouder wordende, verlopen rokkenjager zijn, met een vergooid leven en niets dan walging voor dat leven, als ik ooit nog de moed zou hebben om over mezelf na te denken. (p. 106)

Onder deze projecterende blik van zijn leermeester wordt Hans tot een geabstraheerd ideaalbeeld, waar hij niet aan zal kunnen voldoen. Tijdens een ruzie met Bert realiseert Hans zich, verstrakkend en verstarrend, zijn echec:

Terwijl hij achteruit liep naar de deur, voelde hij hoe strak en emotieloos zijn gezicht moest zijn. Hij dacht: nu weet Bert zeker, dat hij zich in me vergist, dat hij zijn tijd en zijn aandacht jarenlang aan me verspild heeft. Ik ben een nul. Ik neem de benen als een lafaard, langzaam en onopvallend. [...] Het enige dat hij kon bedenken, telkens als hij iets tot zijn verdediging wilde aanvoeren, was: mislukt. Mislukt. MISLUKT. (p. 112-113)

Doordat zijn situatie ten gevolge van zijn ziekte onder druk gezet is, moet Hans zich heroriënteren op zijn leven. Mede door de gesprekken met zijn leermeester beseft hij, dat hij veranderd is. Hij voldoet niet meer aan het beeld dat Bert van hem heeft: een aardige, kinderlijke jongen, die ondanks zijn cynisme in wezen kwetsbaar en onvolwassen is en zijn hulp en toewijding, 'die zoveel op ouderliefde leek', nog erg nodig had. Hij heeft het gevoel dat met het verlies van Bert zijn jeugd pas definitief afgesloten was. Hans bevindt zich in een mentaal niemandsland: het is duidelijk dat de oude situatie niet meer voldoet, dat hij geen behoefte meer heeft aan patriarchale bescherming, het is echter onduidelijk wat ervoor in de plaats zal komen:

Ik had een afspraak met mezelf. Met de nieuwe Hans, die ik worden zou. Met de Hans die nog leefde. Die wéér leefde! Die helemaal opnieuw zou beginnen. Die geen fouten meer zou maken. Of in elk geval minder dan vroeger. Of toch op zijn minst zonder zich van die fouten al te veel aan te trekken. !k had een. afspraak met mezelf, maar ik ben vergeten waar en waarover. [...] Ik kan nog alles doen. Ik kan trouwen zoals alle anderen, kinderen hebben, een gezin. Ik kan desnoods emigreren en in een ander land een toekomst opbouwen voor mezelf of voor mijn gezin. Maar zou ik in dat andere land niet net als hier nu door een stad lopen en denken: Wat wilde ik ook alweer? (p. 31) 
Bert verwijt Hans niet alleen een handelsreizigersmentaliteit op artistiek gebied, maar ook ten aanzien van zijn relaties met vrouwen. Hij probeert zijn vriend ervan te overtuigen dat hij bezig is zijn leven te verknoeien én te verspillen aan onbelangrijk werk en onbelangrijke relaties. Die vriendinnen van hem acht hij niet meer dan een tijdpassering, een vlucht voor verantwoordelijkheid. Als Bert Jacqueline niet was tegengekomen, zou hij geëindigd zijn als een verlopen rokkenjager:

Dan zou ik een heel bestaan verdaan hebben met het zoeken naar iets dat je in dergelijke relaties godsonmogelijk kan vinden: een menselijk contact dat niet staat of valt met de erotiek. [...] Aan een goede erotische relatie is het misverstand inherent. En hoe ongebreidelder zo'n relatie is, des te meer reserve in het menselijke vlak is er nodig. Waarachtige menselijkheid heeft nu eenmaal een sublimerende uitwerking op de erotiek. Maar ik zou niet graag willen dat jij dit soort waarheden uitsluitend van de negatieve kant uit leert inzien. $[\ldots]$ Het enige waar het op aankomt, het enige dat je een ander en je eigen menselijke waardigheid aan te bieden hebt, is werkelijke vriendschap of waarachtig-menselijke liefde. Wat in de grond van de zaak hetzelfde is. (p. 106-107)

Hans relativeert deze in zijn ogen idealistische visie: Bert heeft weliswaar gelijk, maar alleen binnen zijn eigen denksysteem, niet in universele zin. Daar kan hij respect voor opbrengen, zoals voor een werkelijk gelovig mens, zonder echter in zijn god te geloven.

In zijn eigen visie op leven en met name liefde speelt temporaliteit een belangrijke rol. Dat beseft hij des te meer vlak na de dood van Bert. Hoewel de mens weet dat het het leven eindig is, doet hij alsof alle relevante zaken geen beperkte tijdsduur hebben. Dit perspectivisch zelfbedrog is een noodzakelijke voorwaarde om überhaupt ergens aan te beginnen. De mens is zich ervan bewust dat gebeurtenissen episodisch zijn en zich lineair ontwikkelen, dat wil zeggen naar een eindpunt toe, namelijk de dood. In plaats van deze episodische, lineaire realiteit geeft de mens er de voorkeur aan het leven op te vatten als een cirkel, het symbool van oneindigheid:

Alleen de mens ondergat de dood als tegennatuurlijk. Het enige dat hij van zijn leven weet is, dat het een doorlopend gevecht is met de dood. Uit vrees afstand te moeten doen, niet van een werkelijk bezit, maar van een aantal mogelijkheden, waarvan hij tegelijkertijd heel scherp beseft dat ze wel nooit gerealiseerd zullen kunnen worden. Het enige verschil tussen dood en leven is dat de dood kansloos en dus hopeloos is. Het leven is een moedwillig optisch bedrog. Verdriet en geluk en alle nuances daartussen bestaan alleen bij de gratie van het feit, dat je ze in de toekomst kan projecteren. Wanneer je van iets erkent dat er een eind aan komt, begin je er niet aan. Zonder dit perspectivisch zelfbedrog is het onmogelijk om bijvoorbeeld lief te hebben. Je kan niemand omhelzen - wel met de verstandelijke, maar niet met de gevoelsmatige zeker- 
heid, dat na een half uur of een half jaar alle gevoel voor die ander dood kan zijn. Je kan geen enkel gevoel koesteren, geen enkele handeling meer verrichten zonder het geloof, dat er andere gevoelens en andere handelingen op volgen kunnen en dat tot in het oneindige.

Een mens doet wanhopig moeite om het leven dat een rechte lijn is, die ergens abrupt ophoudt, om te buigen tot een cirkel. (p. 192)

\section{Lichaamsbeleving}

Warmonds opvattingen sluiten aan bij de naoorlogse herwaardering van het lichaam. Het idee van een geisoleerde, van lichaam en materie gescheiden geest ontmoet steeds meer bezwaren. De spontane lichaamsbeleving is geen vervanging of het tegengestelde van de 'geest', zij is daar juist een uitbreiding van. Niet-rationele vermogens als irrationaliteit, mystiek, symboliek en oorspronkelijke zuiverheid krijgen binnen deze visie meer waardering. Het lichamelijk bestaan wordt beleefd als een autonome waarde, die geen hogere rechtvaardiging nodig heeft. De levensbron is bereikbaar in het hier en. nu door middel van de spontane beleving. Soms leidt dat tot een sacralisatie van het lichaam, bijvoorbeeld bij een dichter als Hans Andreus:

Gelovigen, vromen en bidders

en alle mensen die koud

of warm of waanzinnig leven, geloof aan de huid van de mens, de mens om het licht heen gebouwd, maar de mens en de mens en de mens. ${ }^{7}$

In de theorie van Lacan valt de subject-wording enerzijds samen met de toegang tot de taal, waarmee het kind zichzelf en de ander kan onderscheiden, anderzijds noet ze betaald worden met een verlies. ${ }^{8}$ De twee-eenheid uit de imaginaire, pre-verbale periode wordt definitief verbroken. Het verliezen van de twee-eenheid brengt automatisch het (terug)verlangen voort, het subject verlangt ermaar dit zijnstekort, dit manque d etre, op te heffen, maar dat kan alleen als het subject zichzelf -als subject- opheft. Lacan acht dit onmogelijk, de mens is volgens hem. definitief uit het paradijs verdreven. Warmonds poëzie echter lijkt te suggereren dat opheffing van het subject -ook al is dat misschien tijdelijk- wél mogelijk is door de controlerende rationaliteit uit te schakelen. Dit idee komt dicht in de buurt van boeddhistische ideeën, waarin het ego door bepaalde methoden getranscendeerd kan worden en een non-dualistische beleving van het zijn mogelijk wordt geacht. Een voor-

7 Hans Andreus, Lied om te leven en dood te gaan. In: Verzamelde gedichten, Amsterdam 1983: 429-431

8 zie A. Mooij, Taal en verlangen. Lacans theorie van de psychoanalyse. Meppel 1997 $7^{7}$ 134-147 
beeld daarvan is het volgende fragment uit Warmonds gedicht 'Wiederaufführung Sternenstunde" waar in het woord 'eenvoudig' de betekenissen 'moeiteloos' en 'non-dualistisch' samenvloeien:
Ademen als ooit alsof
lichaam en geest vanzelfsprekend
zijn en eenvoudig
bijeen

In het gedicht 'Ongeletterd'10 kan het lyrisch subject het lichaam alleen spontaan en direct beleven door te ontsnappen aan een controlerende rationaliteit:

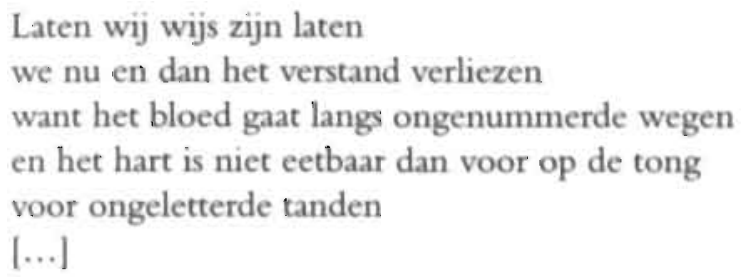

In haar poëzie wordt de opheffing van dualiteit tijdens de liefdevolle sexuele ontmoeting aangegeven door signalen die een zekere mate van directheid en non-rationaliteit aanduiden: vereenvoudigd, automatisch, probleemloos, zorgeloos, ongeletterd, het verstand verliezen e.d.

Ik verwees al eerder naar het verschil tussen het lichaam-als-subject en het lichaam-als-object, ofwel het verschil tussen Leib en Körper. Het lichaam wordt als Leib ervaren tijdens het ongereflecteerde stadium, het zogenaamde eerste-graads bewustzijn, terwijl het lichaam als Körper beleefd wordt tijdens het tweede-graads bewustzijn, het stadium waarin het reflecterende ik het lichaam van zichzelf of van een ander ervaart als vreemd of als een object. Beide lichaamsbelevingen komen voor in Warmonds poëzie, zoals onder meer blijkt uit het gedicht 'Eenvoudig', waarin met name de nuancerende antithese in de derde en vierde strofe ('de hand laten grijpen / niet tasten // het oog laten zien / niet ontleden') het verschil tussen beide lichaamsbelevingen duidelijk maakt:

\section{EENVOUDIG}

De huid vanzelfsprekend bewonen

\footnotetext{
9 in: Kaalslag. Amsterdam 1999: 54

10 in: Warmite, een woonplaats. Amsterdam 1961: 16
} 
het bloed

zijn werk laten doen

5. de hand laten grijpen

niet tasten

het oog laten zien

niet ontleden

het denken laten varen

10. kon ik dat maar. ${ }^{11}$

De roman Paspoort voor niemandsland bevat niet alleen een neerslag van de naoorlogse herwaardering van het lichaam, maar ook van de manier waarop het lichaam beleefd wordt in existentialistische literatuur, waarin de lichaamsbeleving vaak samenhangt met het vervreemdingsmotief: het eigen lichaam of dat van de ander wordt ervaren als object. Tijdens momenten van walging en vervreemding wordt het lichaam ervaren als Körper, maar door de sexualiteit kan dat gevoel naar de achtergrond verdwijnen, waardoor het lichaam meer als Leib ervaren kan worden. Bovendien voelt het personage zich op die momenten min of meer verzoend met het bestaan.

De verhouding tot de ander, en daarmee ook de liefde, is bij Sartre altijd een conflictsituatie die tit zal lopen op een echec. Het pour-soi (het menselijk bewustzijn) verlangt er naar om opgenomen te worden in het en-soi (het zijnde). Misschien kan dit verlangen enigszins bevredigd worden via de omweg van de ander. Het contact van lichaam tot lichaam doet het lichaam opbloeien, de sexualiteit en met name de liefkozing incarneert de mens in actieve zin, waardoor lichaam en bewustzijn één zijn. Het is een opgaan via het lichaam in de wereld. ${ }^{12}$ De mens doet weliswaar wanhopige pogingen de distantie die hem van anderen onderscheidt te overbruggen, maar tussen hem en de ander als 'niet-ik' gaapt de kloof van het néant, juist omdat 'ik' en 'niet-ik' elkaars ontkenning zijn.

Dit dualisme van Sartre wordt bekritiseerd door Merleau-Ponty. ${ }^{13}$ Hij stelt, dat lichaam en existentie elkaar veronderstellen. Noch het lichaam, noch de existentie kunnen doorgaan voor wat oorspronkelijk is in het menselijke zijn. Het lichaam is gestolde existentie en de existentie is een voortdurende belichaming. Onze lichamelijkheid is het oorspronkelijke niveau van zingeving, de bewuste interpretatie ontwikkelt zich hieruit en is dus secundair. Bewustzijn is bij de dingen zijn door tussenkomst van het lichaam. De oorspronkelijke waarneming is een pre-objectieve en voorbewuste ervaring. Het erotisch begrijpen is van een geheel andere orde dan

11 in: Vuchtstroken um de taal. Amsterdam 1988: 23

12 H. Redeker, Existentialisme. Een doortocht door philosophisch frontgebied. Amsterdam 1949:308

13 M. Merleau-Ponty, Fenomenologie van de uvarneming. Amstendam 1997: 200-203 
het verstandelijke begrip, aldus Merleau-Ponty. Het verstand begrijpt doordat het een ervaring vat onder een idee, terwijl de begeerte daarentegen blindelings begrijpt door een lichaam met een lichaam te verbinden. Deze directe manier van kennen beschouwt Merleau-Ponty als oorspronkelijk en fundamenteel.

In hoeverre spelen dit soort existentialistische ideeën een rol in Paspoort voor niemandsland? Het leven van Hans Erkelens, de hoofdpersoon van Warmonds roman, komt onder druk te staan door de mededeling van zijn chirung dat hij nog niet dood zal gaan. Daardoor moet hij zich opnieuw gaan oriënteren op zijn leven, vriendschappen en relaties. Hij moet als het ware bij nul beginnen. De vriendschap met Bert, zijn leermeester, verandert in een conflictsituatic: Hans bevindt zich in een losmakingsproces, hij voelt zich niet meer thuis in de verhouding vader-zoon, terwijl Bert er moeite mee heeft dit te accepteren of het niet doorheeft. Hun discussies over de integriteit als kunstenaar worden onder andere veroorzaakt door Eva's verzoek aan Hans haar portret te schilderen als verjaarscadeau voor haar echtgenoot, een verzoek waar hij overigens niet op ingaat.

Hans raakt door zijn situatie in een existentiële crisis, die samengaat met angsten, walging en vervreemding. Dankzij zijn sexuele relatie met Eva kan hij als het ware de-automatiseren, ont-dingelijken, waardoor hij weer voeling krijgt met het bestaan. De naam van zijn geliefde wordt zo tot een programmatische naam, Eva (Hebreeuws Chawwa) betekent immers 'leven':

Er was iets in hem bevroren. Hij zou alleen kunnen ontdooien aan de warmte van een ander. De warmte van een mens, met een zacht, levend lichaam, dat nog helemaal zijn eigendom is. Eva was zijn paspoort voor het land der levenden. Een niemandsland misschien, maar waarin hij toch tot iedere prijs wilde wonen. Als immigrant, als tourist desnoods.

Hij drukte zijn gezicht in de zachte warmte van haar hals en klemde zich aan haar vast als een verdrinkende ... (p. 97)

Aan het eind van deze paragraaf kom ik terug op de paspoortmetafoor die in deze roman zo'n belangrijke rol speelt.

De verdrinkingsmetafoor in bovenstaand citaat geeft aan dat de erotiek voor de hoofdpersoon fungeert als reddingsboei, als iets waar hij zich aan vast kan klampen om niet ten onder te gaan in een als vervreemdend ervaren leven. Bovendien is de erotiek een middel om terug te keren naar het eerste-graads bewustzijn, waarin dualisme en vervreemding en dergelijke niet aan de orde zijn. Door middel van de sexualiteit kan de hoofdpersoon ontsnappen aan het reflecterende ik van het tweede-graads bewustzijn. Op die momenten verdwijnt de taal, die zo nauw verbonden is met het denken, naar de achtergrond. Dit uit zich onder andere in een verbrokkelde manier van spreken. ${ }^{14}$ De volgende twee citaten illustreren dit:

14 zie: R.C. Kwant, Fenomenologie van de taal. Utrecht/Antwerpen 1963: 196 
'Nu wil ik eens niets meer horen, versta je ... nu hoeven ze me niets meer voor te schrijven ...nu wil ik niets ...nu wil ik alles of niets ... alles en niets ... jij ... jou ... kom dan ... niet aldoor nadenken ... jij ... een brug ... iedereen verzuipt als er geen brug is ...' (p. 127)

Hij moest haar bij zich hebben, haar armen om zich heen voelen om er weer onberedeneerbaar, maar heilig van. overtuigd te zijn, dat hij alleen leven kon als hij daar niet meer doorlopend met zichzelf of met anderen over hoefde te discussiëren ... (p. 149)

Een enkele keer wordt aangegeven hoe Eva's harde, ondoordringbare blik voor Hans een belemmering kan zijn om zijn lichaam als Leib te ervaren. Niet alleen het reflexieve denken dient uitgeschakeld te worden, ook de objectiverende blik van de ander:

Op zijn elleboog steunend, legde hij zijn linkerhand over haar ogen, om die harde, glanzende, tartende blik niet meer te hoeven zien, maakte met zijn andere hand zijn kleren los en liet zich over haar heen vallen. (p. 127)

In het Sartriaanse existentialisme neemt de blik een belangrijke plaats in. De gewaarwording dat ik bekeken word, maakr de aanwezigheid van de ander voelbaar. De observerende blik van de ander maakt mij tot object, zoals ik op mijn beurt de ander tot object kan maken door observerend terug te kijken. Dit wordt ervaren als een inperking van de eigen vrijheid. Beschrijft Sartre de blik meer in termen van macht, Merleau-Ponty stelt het communicatieve element van de blik centraal. De blik van de ander maakt mij alleen tot object en vice versa, als we allebei onze blik onmenselijk laten worden en elkaar gaan observeren zoals we een insect bekijken. Maar zelfs dan wordt zo'n objectiverende blik van de ander alleen als pijnlijk gevoeld, doordat deze de plaats van een mogelijke communicatie inneemt. ${ }^{15}$ Beide belevingen zijn terug te vinden in onderstaand romanfragment van Simone de Beauvoir, waarin de psychiater Anne Dubreuilh een one-right-stand heeft met de uit Rusland gevluchte schrijver Seriassine. Aan de ene kant voelt zij zich uitgeleverd aan zijn blik, waardoor zij zich bewust wordt van haar lichaam als Körper ('vlees'), aan de andere kant ervaart ze zijn oproep om elkaar aan te kijken als een poging tot contact:

'Doe je ogen open.' Ik bracht mijn oogleden omhoog, maar ze wogen zwaar en vielen uit zichzelf terug over mijn door het licht gekwetste ogen. 'Doe je ogen open,' zei hij. 'Jij bent het, ik ben het.' Hij had gelijk en ik wilde onszelf ook niet ontvluchten. Maar ik moest eerst nog wennen aan die ongewone aanwezigheid: mijn vlees; naar zijn vreemde gezicht kijken en onder zijn blikken me in mezelf

15 M. Merleau-Ponty. Fenomenologie van de wuarneming. Amsterdam 1997: 419 
verliezen, dat was te veel tegelijk. Ik keek naar hem, omdat hij dat eiste; ik bleef halverwege de onscherpte hangen, in een gebied zonder licht en zonder donker, waarin ik lichaam noch vlees was. Hij sloeg het laken terug en op hetzelfde ogenblik bedacht ik dat de kamer slecht verwarmd was en dat ik niet meer de buik van een jong meisje had; ik leverde aan zijn nieuwsgierige blikken een naaktheid uit die het koud noch warm had. ${ }^{16}$

Welke rol speelt de blik in de verhouding tussen Hans en Eva? Meerdere malen worden Eva's ogen beschreven als hard, scherp en ondoorgrondelijk:

Het waren wonderlijke, fascinerende ogen. Meer dan ooit leken ze op de ogen van een kat; het licht in zich verzamelend en weer terugkaatsend. Het waren ogen zonder ziel, glanzende, fonkelende juwelen. Hij dacht: ze kan er mee zien, maar niet mee kijken. Hij wist zelf niet wat hij daarmee bedoelde. (p. 95)

Opmerkelijk is het onderscheid dat gemaakt wordt tussen zien en kijken. De termen 'terugkaatsend', 'glanzend' en 'fonkelend' doen denken aan het effect van een zonnebril waarin je in plaats van de ogen van de drager jezelf ziet. De combinatic 'fonkelende juwelen' benadrukt vooral de hardheid en het dingachtige karakter van haar ogen. De gehele beschrijving van Eva's ogen roept vooral ondoordringbaarheid op. Zien wordt in bovenstaand citaat gebruikt voor een objectiverende, neutrale, afstandelijke manier van kijken. Dit doet vermoeden dat kijken geassocieerd wordt met persoonlijke betrokkenheid en gerichte aandacht, iets waar Eva zich liever niet mee in wil laten. Dit blijkt ook uit het feit, dat ze Hans cen afscheidsbrief schrijft op het moment dat ze meer geïnvolveerd dreigt te raken in haar relatie met Hans dan ze wil. Het is treffend dat ze in haar brief met betrekking tot hun relatie het beeld gebruikt van twee evenwijdige lijnen die elkaar niet mogen raken:

Begrijp me alsjeblieft: wij zijn als twee evenwijdige lijnen, waartussen de enige kans op geluk ligt, maar evenwijdige lijnen die elkaar nooit mogen snijden (p. 161)

Dit beeld gebruikte Warmond overigens al eerder, namelijk in het gedicht Slaapwandelen ${ }^{17}$ :

Op ongelovige voeten

slaapwandelen door de nacht

onder lage zwaarmoedige wolken

tussen hoge gesluierde huizen

16 Simone de Beauvoir, De mandarijnen. Amsterdam $1996^{18}$ (1954), p. 88

17 In: Naar men zogt. Den Haag 1955: 26 


\author{
zijn wij dit \\ twee vreemden \\ in een verlaten stad \\ geen vreemdelingendienst \\ verschaft ons onderdak \\ twee evenwijdige lijnen \\ in een oneindig vlak.
}

Ook de film- en toneelmetafoor passen in dit beeld: het is niet duidelijk wie Eva werkelijk is, ze speelt een rol, de ene keer is ze het romantische naïeve schoolmeisje, de andere keer de doorgewinterde femme fatale. Haar vermogen om van de ene rol in de andere te stappen wordt met ironische distantie beschreven in het volgende citaat:

Ze liet haar oogleden zakken als een toneelgordijn voor een decorwisseling. Toen ze hem weer aankeek stonden haar ogen dieptriest. (p. 146)

Als hum erotische relatie voorbij is, verandert Eva in Hans'ogen in een objectachtig type, in een 'dame'. Dat is in zijn vocabulaire een denigrerende kwalificatie voor 'een sexloos wezen', dat aan geen enkele emotie appelleert, zelfs niet aan zijn hoffelijkheid. Je kunt je als lezer overigens afvragen of Eva daarvóór wél door Hans als subject werd ervaren. Hij heeft Eva nodig om zichzelf te bewijzen dat hij nog iets van levenshonger in zich heeft. Het lijkt er op, dat zij voor hem meer een functie dan een persoon is, iets waarvan hij zich bewust is:

lk ben alleen maar [...] geobsedeerd op een manier die ik helemaal niet kende. En dan niet door jou zoals je bent, maar door een sfeer die met jou samenhangt, of liever: door een levensbelang dat ik voor mezelf aan jou toeken. En daardoor word jij een volstrekte ander dan die je bent. Dat is verdomd vervelend. Het maakt mijn houding naar twee kanten moeilijk, ten opzichte van jouw werkelijke ik en ten opzichte van een fantasiefiguur of liever: een fantasiesfeer. (p. 142)

Bij haar vindt hij weliswaar de zekerheid terug dat hij weer leeft, maar dat is niet genoeg om de relatie voort te zetten. Het is volgens hem stom toeval dat juist zij hem die stap van niet-leven naar weer-wél-leven heeft laten doen.

In de roman komt ook de klassieke verbinding tussen Eros en Thanatos aan de orde. In een van de cursieve passages wordt het verlangen naar liefde en erotiek in een breder kader geplaatst door dit verlangen te verbinden met de doodsangst, die de mens van zijn eigen lichaam vervreemdt. Alleen door je te verbergen in de armen van een ander kun je de doodsangst op een afstand houden. Deze visie is vergelijk- 
baar met die van het existentialisme, waarin het verlangen opgenomen te willen worden in het en-soi bevredigd kan worden via de omweg van de ander. Door het contact van lichaam tot lichaam incarneert de mens in actieve zin, hervindt hij zichzelf:

Omdat een mens een doodsbang en ellendig dier is, dat tegelijk met zijn kleren een bepaalde zekerheid. om zich heen hangt warin hij tot iedere prijs wil geloven, al was het maar omdat de anderen, de toeschouwers, de buitenstaanders, erin geloven. En die anderen, die buitenstaanders, zijn ook weer stuk voor stuk doodsbange, machteloze dieren, die hetzelfde doen. Misschien hopen ze dat die zekerheid, naarmate hij echter lijkt ook echter wordt. Een werkelijke bescherming tegen het enige gevaar waarvoor ze zó bang zijn dat ze er zelfs niet aan durven denken. Denken, niet in filosofische zin, of achter het schild van een religieus voorbehoud, maar je als het ware lichamelijk bewust maken dat je dood om je heen aan alle kanten voor je klaar kan staan. Je lichamelijk vereenzelvigen met het besef hoe het zijn moet als je hart ineens hapert en dan ophoudt met kloppen. Als je er ineens in je hersens iets lijkt te scheuren. Als er ineens iets is, dat je adem de doorgang belet. [...]

Alleen dáárom verbergen mensen zich in de armen van andere mensen. Willen ze armen om zich heen voelen, die hen vasthouden; omdat het onmogelijk lijkt dat het gebeuren zou zolang iemand je maar dicht genoeg bij zich vasthoudt. Omdat een mens, die zich vertrouwd heeft proberen te maken met zijn eigen dood, van zijn eigen lichaam vervreemd is, zo zeer dat het zijn eigendom, zijn bezit niet meer is. Hoogstens kan het dan nog eigendom zijn van een ander en door die ander aan hem teruggegeven worden. (p. 96-97)

De lichaamsbeleving in Warmonds roman sluit niet alleen aan bij existentialistische ideeën, maar ook bij de naoorlogse hẹwạardering van hẹt lichaam, die onder andere gekenmerkt wordt door het ontsnappen aan een controlerende rationaliteit, oorspronkelijke zuiverheid, mystiek en symboliek. ${ }^{18}$ Deze aspecten zijn ook terug te vinden in Paspoort voor niemandsland. Alleen door het controlerende, reflexieve denken uit te schakelen ontstaat de Leib-beleving in het eerste-graads bewustzijn. Het orgasme levert de hoofdpersoon welhaast mystieke ervaringen op, waarin ruimte en tijd als het ware wegvallen en hij vervuld wordt van

het reinigende, ruimteloze besef van volledige wedergeboorte (p. 125)

De orgastische momenten gaan bij Hans gepaard met visioenachtige gewaarwordingen, waarin hij zichzelf ziet en ervaart als een Chinese prins. Deze ogenblikken,

18 Hugo Brems, Lichamelijkheid in de experimentele poezie. Bijdnage tot de kanakterisering en de literair-historische situering un de moderne Nederlandse poezie 1950-1960. Hasselt 1976:113 c.v. 
die hij de 'chinese momenten' noemt, doen niet alleen mystiek aan door het opheffen van tijd en ruimte, maar gaan ook gepaard met vitalistische sensaties. Op zulke momenten dacht hij:

Dit is de laatste vraag en het laatste antwoord. Nu kan mij niets meer gebeuren. Ik heb de tijd op zijn staart getrapt. Als ze nu de hele eeuwigheid op me neerdonderen, zal ik hem met een luchtig handgebaar opzij schuiven. Ik kom geen tijd meer tekort. Ik heb ook geen tijd meer over. Ik ben zélf tijd. Ik ben een gebeurtenis. Een vast punt in het heelal. En dat heelal ben ik óók weer zelf. [...] Gaf zij hem zijn wereld terug, hij zou haar de hare niet alleen teruggeven, maar met nog een aantal ándere werelden erbij. Wie een heelal beheerde kon royaal zijn met het uitdelen van werelden, planeten, spiraalnevels, meteoren en de komeet van Halley. De laatste nu eens niet één keer in de honderd jaar, maar zo vaak ze maar wilde. (p. 138-139)

In Warmonds poëzie zijn aanduidingen van het eerste-graads bewustzijn te herkennen aan signaalwoorden die een zekere mate van directheid aangeven: vanzelfsprekend, eenvoudig, zorgeloos, probleemloos, natuurlijk, onvatbaar, terugkeer en oorsprong. Hoewel deze woorden niet letterlijk voorkomen in Warmonds roman, zijn ze wel van toepassing op de manier waarop de hoofdfiguur van de roman de erotiek en zijn lichaam ervaart. De visioenen zijn louter visueel en non-verbaal. Hans wil er ook eigenlijk niet over praten, tit angst dat de visioenen dan verdwijnen. Bovendien heeft hij het idee dat rationele verklaringen de zuiverhid van zijn ervaringen aan zullen tasten:

Als je erover nadacht, vee! over nadacht, zou je de volgende keren bepaalde visionaire verwachtingen kunnen koesteren, die dan of teleurgesteld zouden worden of in elk geval onecht -want van buitenaf opgeroepen of aangemoedigd-zouden lijken.

Toen hij dan ook een keer een essay in handen kreeg waarin het optreden van mystiek-religieuze en erotische visioenen verklaard werd vanuit een verstoring van het chemisch-organische evenwicht - te snelle of belemmerde ademhaling veroorzaakt een verhoogde concentratie van kooldioxide in het bloed, de remmende invloed van een veiligheidsklep in de hersens wordt verminderd en de visioenen hebben vrij spel- sloeg hij het boek, ondanks zijn nieuwsgierigheid, na een paar bladzijden al dicht. Hij had genoeg beredeneerd in zijn leven. En alles wat hij ooit. verklaard had, had hij dood verklaard. Daar zou hij voortaan maar mee ophouden. (p. 139) 


\section{Niemandsland}

Uit het voorafgaande blijkt, dat erotiek een belangrijke rol speelt in Warmonds roman. Hans ervaart Eva als 'zijn paspoort voor het land der levenden', dat wil zeggen: in de erotiek voelt hij weer verbinding met het leven, het zijnde. Eva moet hem verlossen van de vervreemding, van de dood. Dankzij de erotiek kan hij zich wat meer thuis voelen in deze wereld. In hetzelfde jaar als Paspoort voor niemandsland verscheen de dichtbundel met de veelzeggende titel Warmte, een woonplaats (Amsterdam 1961).

Hans wil zijn 'verlossingshonger'stillen via de ander. Eva is voor hem niet meer dan een functie. Op het moment dat ze hem verlaat, haat hij haar:

Niet omdat ze hem afdankte, maar omdat ze hem daarmee de pas afsneed naar zijn nieuwe leven, waarin hij blijkbaar nog steeds de weg niet wist. (p. 163)

De erotiek is voor Hans een toegang tot dat andere leven, zoals een paspoort noodzakelijk is om een land binnen te komen. Op het moment dat iemand zich in het beoogde land bevindt, moet hij zelf zijn weg vinden: alleen of met behulp van een gids. Een uitgebreid metafoorpatroon maakt duidelijk, dat Hans daar niet geheel in slaagt. Hij voelt zich achtereenvolgens een 'immigrant', een 'tourist', een 'displaced person', een 'melaatse', een 'indringer', een 'spion', een 'vijand' en een 'overlevende'. Niet alleen erotiek, maar ook vriendschap kan ervoor zorgen, dat iemand zich meer thuis gat voelen in het 'land der levenden'. Hans noemt zijn vrienden Bert en Jaap immers respectievelijk zijn 'gids' en 'inheemse begeleider'. Als zowel de erotiek als de vriendschap wegvallen, voelt Hans

zich verdẹ van die anderen verwijderd dan ooit, alsof ze niet werkelijk bestonden, alsof hij de enige overlevende was na een ramp, die alle leven van de hele aarde had weggevaagd en alsof die anderen alleen nog in zijn herinnering bleven voortbestaan. (p. 193)

Op dat moment ervaart Hans anderen als onwerkelijk. Hij voelt zich volkomen van hen vervreemd. Het is niet voor niets dat in deze roman het beeld van het niemandsland wordt gebruikt. Een niemandsland is een gebied tussen twee grensposten in of een tussengebied dat geen van de strijdende partijen het zijne kan noemen. In deze roman is het niemandsland het gebied tussen enerzijds volledige vervreemding en anderzijdss werkelijk, volledig contact met de ander. Vóór hij Eva ontmoette, was hij

al die dagen schijndood geweest. Hij had rondgelopen, gepraat, gegeten, gedronken en geslapen als een automaat. (p. 97) 
Het dingmatige bestaan, omschreven door vervreemding aangevende woorden als 'schijndood' en 'automaat', wordt door de erotiek in ieder geval enigszins doorbroken. Hans omschrijft dit proces als een 'ontdooien'. Dit woord geeft net als de term 'niemandsland' een tussenfase aan: niet meer bevroren, maar ook nog niet helemaal gesmolten. Erotiek doorbreekt weliswaar de vervreemding, maar slechts ten dele. Het leven, in ieder geval Hans' leven, is een strijd om de vervreemding de baas te blijven.

Het 'niemandsland' is ook het land van de anderen, waar niemand voor Hans een eigen gezicht heeft. Hij kijkt naar hen als een toerist naar de autochtone bevolking. Tegelijkertijd is Hans voor de anderen een 'niemand', niet meer dan een toevallige passant:

Hij voelde zich een indringer, die niet in het leven van anderen paste, zomin als hij paste in het leven van Eva. Een spion, dacht hij, een vijand. Niemand kijkt naar me, maar iedereen ziet me. (p. 155)

Het niemandsland is tevens het land waar niemand zichzelf werkelijk laat zien, waar men zich verschuilt achter clichés en ironic. Voorbeelden van bewoners van dit geestelijk niemandsland zijn de mensen die de Olympus-bar bezoeken en de gasten op Eva's partijtjes. Het zijn karikaturen van zichzelf.

Kortom, Warmond speelt in haar roman een intelligent spel met de term 'niemandsland', waarvan de betekenis telkens enigszins verschuift. 


\section{EXISTENTIALISTISCH PASPOORT 2}

In het vorige hoofdstuk werden twee belangrijke existentialistische thema's besproken: de grenssituatie en de ander. In dit vijfde hoofdstuk wordt aandacht geschonken aan de andere kenmerken van het literaire existentialisme: engagement, gesloten ruimtes, geseculariseerde invulling van christelijke begrippen, het classificatieprocédé en registerwisselingen. Ten slotte wordt de receptie van Paspoort voor niemandsland besproken.

\section{Engagement}

In de definitie van Van Stralen is engagement niet beperkt tot politieke betrokkenheid.

De gespannen situatie waarin het romanpersonage zich bevindt, leidt tot het inzicht dat een keuze onvermijdelijk is. Elke bewuste beslissing die dan genomen wordt. beschouwt Van Stralen als een vorm van engagement. Dit engagement kan drie kanten uit gaan: totale berusting, heroriëntering en aanvaarding of daadwerkelijke verandering van de situatie. Er is een verband tussen deze keuzes en de mate waarin het personage gelooft in persoonlijke vrijheid.

Weinig vertrouwen in de persoonlijke bewegingsvrijheid leidt tot totale berusting, ook al wordt de situatie als negatief ervaren. Het romanpersonage dat deze weg kiest, probeert zich vaak overeind te houden door cynische kritiek op de bourgeoisie en op het meeloopgedrag van de grote massa. Alleen op die manier meent hij iets van zijn eigen authenticiteit te kunnen behouden. Niet zelden ontaardt zijn gedrag in zelfdestructieve neigingen of ressentiment.

In het tweede geval (heroriëntering en aanvaarding) komt het personage door de gespannen situatie tot nieuwe inzichten en besluit hij opnieuw maar dit keer bewuster zijn situatie te aanvaarden, sadder but wiser. Door deze nieuwe en bewuste keuze heeft dit personage iets meer authenticiteit bereikt dan het personage dat op. fatalistische wijze kiest voor de totale berusting. In het esthetisch existentialisme wordt authenticiteit vaak geassocieerd met het pre-rationele domein of met romantische thema's als de verloren onschuld van de jeugd en de zuiverheid van de natuurmens. Erotiek kan het leed vaak verlichten of -ook al is dat dan misschien tijdelijk- opheffen.

De laatste keuze (verandering van de situatie) komt vooral voor in het ethisch existentialisme. Door een groot vertrouwen in de reikwijdte van de persoonlijke vrijheid kan het personage zijn situatie daadwerkelijk ten goede veranderen. Dit vertrouwen gaat samen. met een groot gevoel van verantwoordelijkheid voor de maatschappij en de ander. Deze keuze komt dicht in de buurt van het politieke engagement van Sartre.

De vraag doet zich voor welke vorm van engagement terug te vinden is in Paspoort voor niemandsland. De laatste vorm is er niet in terug te vinden, aangezien maat- 
schappelijke betrokkenheid nauwelijks een rol speelt in dit boek. De eerste vorm, cynische berusting, wordt gekenmerkt door scherpe kritiek op het de burgerlijkheid en door zelfdestructie. Hoewel Hans Erkelens zich blijkens een enkele passage afzet tegen met name de benepen burgerlijkheid van zijn ouders, is dit geen dragend onderdeel van zijn levenshouding. De enkele keren dat hij zich bedrinkt, zijn incidenten, geen doelbewuste pogingen tot zelfdestructie. Ook zijn geworstel en opstandigheid wijzen niet in de richting van berusting. Blijft over de tweede vorm, waarin het personage na een grondige heroriëntatie sadder but wiser zijn situatie opnieuw aanvaardt, mede dankzij de verzachtende invloed van de erotiek.

De grenssituatie waar Hans Erkelens door zijn ziekte in terechtkomt, dwingt hem opnieuw zijn positie te bepalen. In eerste instantie levert dit een perspectief vol nieuwe mogelijkheden op, maar al spoedig blijkt dat hij daar niet goed raad mee weet. Hij komt in een soort niemandsland terecht: de oude situatie voldoet niet meer, maar hoe het dan wel moet, is niet duidelijk:

Ik had een afspraak met mezelf. Met de nieuwe Hans, die ik worden zou. Met de Hans die nog leefde. Die wéér leefde! Die helemaal opnieuw zou beginnen. Die geen fouten meer zou maken. Of in elk geval minder dan vroeger. Of toch op zijn minst zonder zich van die fouten al te veel aan te trekken. Ik had een afspraak met mezelf, maar ik ben vergeten waar en waarover. (p. 31)

Vóór die periode is Bert de belangrijkste mens in rijn leven, daar kan geen geliefde tegenop. Hij is zijn referentiekader, jemand die hem als een vader houvast en zekerheid biedt. Welke proporties dat kon aannemen, blijkt uit de scherpe analyse van Esther, zijn ex-geliefde:

Bert zou zeggen ... Bert zou dit doen ... Bert zou dat doen ... Bert was zo geweldig. Bert was zo'n beste vriend. Bert was zo'n goed mens ... Als je niet beter wist, zou je nog heel wat gaan denken van die vriendschap. Zou die Bert dat prettig vinden on als God allemachtig beschouwd te worden? Zou dat niet verschrikkelijk irritant zijn: aldoor de verering van zo'n volwassen padvinder. om je heen? Dat verplichtte je om doorlopend op je tenen te staan. Je mocht nooit eens doen waaruit blijken zou, dat je niet zo volmaakt was. Of eigenlijk. ook wél: voor zo iemand was je natuurlijk, behalve almachtig en alwetend, ook. onfeilbaar. Een soort privé-godsdienstje. (p. 99)

Na zijn crisis komit Hans (27!) in een scort verlate puberteit terecht. Hij besluit zich los te maken van Berts bevoogding, voortaan volgt hij zijn eigen. weg. De 'wijze' raadgevingen van zijn vriend irriteren hem, het zijn hinderlijke inbreuken op zijn persoonlijk leven. Tijdens een gesprek met zijn jeugdvriend Jaap, die hem advies vraagt over een bepaalde kwestie, realiseert Hans zich hoezeer hij beïnloed is door zijn leermeester: 
Hij hield plotseling op. Waarom deed hij zo agressief? Wie was er hier aan het woord, Bert of hij? Dit waren de principes van Bert; principes waarvoor Bert met zijn leven zou instaan. Maar hijzelf? Had hij het recht Jaap aan te vallen met Bert's wapens? Kon hij zich opwinden als een ander niet onmiddellijk theoretisch met hem eens was wat hij zelf in de praktijk misschien niet zou aankunnen? Ja Bert. Nee Bert. Goed Bert. (p. 121)

Ineens ziet hij zichzelf via de ogen van een ander, namelijk vanuit zijn nieuwe ik. Hij beseft dat hij zijn eigen referentiekader moet formeren, uitgaande van wat hij zélf relevant en essentieel vindt. Dit leidt tot een heroriëntatie op werk en relaties. Hij conformeert zich niet (meer?) aan het idee, onder meer geventileerd door Bert, dat zijn integriteit als kunstenaar in het geding is nu hij niet meer vrij schildert. Ondanks het feit dat hij opgeleid is tot kunstschilder kiest hij voor het reclamevak, omdat er nu eenmaal brood op de plank moet komen. Hij beoefent zijn vak niet alleen uit pragmatische overwegingen, zijn werk fungeert in moeilijke tijden ook als een bancirkel waarbinnen hij zich terug kan trekken.

Berts negatieve kijk op Eva, gebaseerd op een eigen vroegere ervaring met haar, makt geen indruk op Hans. Ook in deze kwestie vormen de ideeën van zijn leermeester niet meer zijn referentiekader, hij bepaalt zelf zijn positie. Hoewel zijn relatie met Eva op een echec uitloopt, komt hij er, sadder but wiser, uit tevoorschijn als een ander mens. Dankzij haar, of beter dankzij de erotiek komt hij weer terug in het land der levenden, kan hij de band met het bestaan weer herstellen. Zoals ik al eerder betoogde, is Eva voor hem veeleer een functie dan een persoon. Bovendien komt hij middels de erotiek in een pre-rationeel domein waarin hij bevrijd is van een controlerende rationaliteit. Dit doet hem besluiten zich voortaan niet meer zo te fixeren op het denken, maar zich meer te gaan richten op het doen.

$\mathrm{Na}$ zijn echec met Eva herstelt de vriendschap met Bert zich weer, maar nu met minder 'padvinderachtige' trekken. In een eerder exposé betoogde zijn leermeester dat vriendschap door haar blijvend karakter belangrijker is dan vluchtige erotiek. Het lijkt erop dat Hans zich uiteindelijk bij deze visie aansluit:

Hij voelde zich feestelijk gestemd. De afgelopen maanden had hij zich als een klein kind gedragen. Daarnet met Eva wel het allerergste [in een etablissement had hij uiterst koel tegen haar gedaan]. Maar dat was nu voorbij. Een koortsdroom, die je maar vergeten moet. Eva was weg en Bert was weer terug. Hij voelde zich nu pas werkelijk genezen. (p. 183)

Dat dit een wankel evenwicht is, blijkt uit zijn reactie op de dood van zijn vriend. Hij zal opnieuw zijn positie dienen te bepalen. Dit wordt gesymboliseerd door het open einde, dat tegelijkertijd een circulair einde is, omdat we hier net als in het begin een radeloze toofdpersoon zien in de buurt van zijn oude HBS. Opnieuw 
wordt hij overvallen door de absurditeit van het bestaan en ervaart hij op nogal letterlijke wijze een gevoel van nausée.

\section{Absurditeit of het existentiêle misverstand}

Een belangrijk motief in literair-existentialistische literatuur is het existentiële misverstand of de absurditeit, door Camus omschreven als de spanning tussen het menselijk verlangen naar eenheid en duidelijkheid enerzijds en het redeloze zwijgen van de wereld anderzijds. Het absurde zit in geen van beide elementen, het wordt geboren uit hun confrontatie. Vervreemding en walging zijn hier uitingsvormen van. Tussen de zekerheid dat ik besta en de inhoud die ik aan deze zekerheid probeer te geven ligt een onoverbrugbare kloof, aldus Camus. ${ }^{1}$ Altijd zal ik een vreemdeling voor mezelf blijven. lemand die geen enkele hoop koestert en zich daarvan bewust is, maakt niet langer deel uit van de toekomst. Dit is onvermijdelijk, zoals het ook onvermijdelijk is dat iemand hieruit probeert te ontsnappen, door Camus aangeduid als een (ontsnappings)sprong. Hij vindt dit weliswaar begrijpelijk maar niet juist. Camus wil weten of hij kan leven met wat hij weet en daarmee alleen. Zoeken naar wat waar is, is niet hetzelfde als zoeken naar wat wenselijk is. Het kenmerkende van de absurde mens is dat hij niet in de diepe betekenis der dingen gelooft. De sprong uit het absurde kan verschillende kanten uitgaan:geloven in het goddelijke of het eeuwige, opgaan in de illusies van het dagelijks leven of van een idee. Deze ontsnappingssprongen zijn allemaal oogkleppen om het absurde niet onder ogen te hoeven zien. Geen hoop meer hebben is echter niet hetzelfde als wanhopen. Iemand is een wijze als hij leeft van wat hij heeft zonder te speculeren op wat hij niet heeft:

Als de absurde mens om te ontsnappeñ aan de angstige vraag: "Wat zou het leven dan zijn?' zich als een ezel moet voeden met de rozen der illusie dan neemt hij, liever dan zich neer te leggen bij de leugen, onbevreesd het antwoord van Kierkegaard aan: 'de wanhoop'. Alles welbeschouwd zal een vastbesloten geest daar altijd aan kunnen wennen. ${ }^{2}$

Drie wegen staan open voor de mens die zich bewust is van het absurde: zelfmoord plegen, de ontsnappingssprong of de uitdaging aangaan die het absurde inhoudt. Dat het leven zin-loos is, wil namelijk niet zeggen dat het niet de moeite waard is om geleefd te worden. De absurde mens wil weten of het mogelijk is te leven zonder zich ergens op te beroepen. Leven betekent het absurde onder ogen zien, wie het bewuste verzet opgeeft, ontwijkt het probleem alleen maar:

De zelfmoord is geen logisch gevolg van de revolte, maar juist het tegenoverge-stelde, omdat van iemand die een eind aan zijn leven maakt, wordt veronder-

1 Albert Camus, De myte un Sisyfus. Een essay over het absurde. Amsterdam 1975 (1942): 26-27

2 Camus, 1975:52 
steld dat hij zijn lot aanvaardt. Evenals de sprong houdt de zelfmoord de meest extreme vorm van aanvaarding in. [...] De geest mag de nacht niet ontwijken, zeggen mystici en existentie-filosofen. Zeker, maar niet de nacht die ontstaat wanneer de mens zijn ogen sluit. Eerder de nacht van de wanhoop, waarin hij zijn scherpzinnigheid niet verliest, een poolnacht, waarin de geest waakzaam blijft. $^{3}$

Het existentiële misverstand of de absurditeit speelt met name in het leven van de hoofdpersoon en in dat van Esther Engelrijk, zijn voormalige vriendin, een grote rol. Er is een belangrijk verschil in de keuzes die beiden maken: Hans kiest ondanks alles, voor 'Lebensbejahung', terwijl Esthers leven door haar keuze voor suïcide uiteindelijk resulteert in 'Lebensverneinung'. Ik ga hier nu niet verder in op de absurditeit in het leven van Hans, dat is in voorafgaande paragrafen al uitvoerig aan de orde gekomen. In deze paragraaf staat Esther centraal.

Esther Engelrijk (what's in a name?), 32 jaar oud, mooi, waarschijnlijk angliste (het is niet duidelijk of ze haar studie heeft afgemaakt), promiscue levenswandel, wordt door Hans gekarakteriseerd als een vrouw, "die alles amusant vond en niets de moeite waard' (p. 97). Door haar ontmoeting met Karin, een ex-geliefde en de enige die haar rust kon geven indertijd, beseft ze ineens hoeveel tijd ze intussen vergooid heeft. Ze voelt zich leeg, oud, op en fanée. Twaalf jaar geleden woonde Karin bij haar in huis, tot ze er allebei door haar ouders uitgegooid werden. Met ironische distantie vertelt Esther aan Hans hoe haar ouders in het bijzijn van de hele familie tijdens een soort bezweringsritueel al hun kleren hebben verbrand. Karin ging terug naar haar ouders, zich daarbij conformerend aan hun afkeurende houding ten aanzien van homosexuele relaties. Het idee dat Karin haar afgenomen is, wordt later door Esther als volgt gecorrigeerd:

Nee, ze hadden me iets veel belangrijkers afgenomen: het vermogen om met hersenschimmen te leven. Dat geloofde ik toen nog, dat je met hersenschimmen leven kon. Of nóg erger: dat je zonder hersenschimmen geen leven had! (p. 70)

Dit impliceert, dat ze de absurditeit van het bestaan volledig onder ogen moet zien, aangezien één van de door Camus genoemde ontsnappingssprongen, de sprong naar een bestaan vol illusies, voorgoed onmogelijk is. Deze confrontatie met de absurditeit veroorzaakt walging en vervreemding. Zoals vaker bij Warmond treden deze motieven in combinatie met het spiegelmotief op:

Ze stond op en bekeek zich in de spiegel boven de wastafel. Dit is mijn gezicht. Er was geen gezicht denkbaar waar ze zoveel weerzin voor voelde. Ze bracht haar arm omhoog en zag in de spiegel een kleine, sierlijke hand, die als de hand

3 Camus, 1975: 68 
van een blinde met de vingertoppen langs de huid tastte: langs een hoog, glad voorhoofd, een tamelijk lange, rechte neus, met duidelijk getekende, schuin-oplopende neusvleugels, langs een grote, gulzige mond en een kleine ronde kin. Ze keek in de spiegel alsof die hand door een ander bestuurd werd. Alsof het verrassend zou zijn, te zien wat er verder zou gebeuren. Rond de hals bleef de hand liggen: een kalme schroef van vlees. (p. 101)

Het vervreemdingsmotief wordt net als bij de hoofdpersoon versterkt door de filmmetafoor, zoals in het volgende citaat waarin en passant ook duidelijk wordt wat de diepere achtergrond is van Esthers promiscuïteit. De erotiek is bedoeld om de controlerende rationaliteit uit te schakelen, maar dat mislukt:

En niemand heeft ooit geweten of zelfs maar vermoed dat ik daar volstrekt niet bij betrokken was. Dat ik erbuiten stond, dat ik in gedachten commentaar leverde, als de onderschriften bij een film. En ik zweer je dat ik het eerlijk geprobeerd heb. Dat ik op de duur nergens anders meer aan dacht dan aan die poging om mezelf te vergeten, om mezelf eens te verliezen aan een ander. Ik geloof niet dat ik het kan. Nooit ... (p. 74)

Aan de ene kant verlangt ze naar authenticiteit, aan de andere kant schuift ze de verantwoordelijkheid daarvoor af op God. Ze heeft blijkbaar weinig vertrouwen in haar eigen persoonlijke vrijheid. Toch kiest Esther niet voor een vlucht in de godsdienst, aangezien ze zich verdoemd acht:

Nou, als je [Hans] dan werkelijk wat voor me doen wilt, verzin dan maar een nieuwe, onafgesletem, enorme rochelende vloek voor me. Dát zou ik wel willen: lang en hard en afdoend vloeken. Want wat kan ik zélf helemaal verzinnen? Godvergodvergodvergodver... Verder kóm ik niet eens. God-ver-wát-eigenlijk? Niet eens godverdómme! 'God verdoem mij' is dat. Nou, dat is al gebeurd neem ik aan. Daar heb ik niks aan. Godvermijme! Ja, dat zou het kunnen zijn: Godvermijme! God uitdagen me mij te maken en nu eens niet de projectie van een ander. Godvermíjme! (p. 72)

Een vlucht in een ideaal, een andere ontsnappingsmogelijkheid, lijkt voor Esther ook afgesloten:

Ik heb nooit iets gewild. Andere mensen willen allemaal iets. Iets bereiken. Iets worden. Als ze thuis niet gewild hadden, dat ik ging studeren, had ik ook dat niet gedaan. (p. 102)

Aangezien twee ontsnappingssprongen, de vlucht in illusies en de vlucht in godsdienst of ideaal, niet mogelijk zijn, rest. Esther nog slechts één andere mogelijkheid: 
de zelfmoord. Iemand die zelfmoord pleegt legt in zekere zin een bekentenis af, aldus Camus. Wie hiertoe overgaat, bekent dat hij het leven niet de moeite waard. vindt, omdat hij het leven niet meer aankan of begrijpt. Het is een poging om te ontsnappen aan de absurditeit van het bestaan. Volgens Esther is er voor zelfmoord geen moed nodig, alleen maar onverschilligheid, moeheid of verveling, typisch. kenmerken die het absurde levensgevoel markeren. Haar daad komt niet voort uit een teveel of uit een tekort, zoals Esther zelf aangeeft:

En Maud zal zeggen: 'Wat ik van belang vind, is de vraag of zoiets nou gebeurt uit een teveel of uit een tekort.' Uit geen van tweeën. Uit een vacuüm. (p. 103)

Op de hotelkamer, waar ze uiteindelijk een overdosis pillen zal nemen, overdenkt ze de mogelijke commentaren op haar daad. Het verlangen naar eenvoudige, overzichtelijke antwoorden kwalificeert ze als een vlucht, als een methode om zich er verder niet mee mee bezig te hoeven houden:

De meeste mensen willen alleen het 'waarom' weten, omdat ze dan zelf de mogelijkheid van zich afgeschoven hebben. Dan kunnen ze zeggen: Weet je waarom? Hij of zij had een ongelukkige liefde. Of, hij of zij had een ongeneeslijke ziekte, of speelschulden, of een misdaad op zijn geweten. Dáárom! Als je op zo'n vraag naar het waarom zou antwoorden: 'Waarom niet?', dan zouden ze onzeker worden, dan zouden ze gaan twijfelen aan het goed recht van hun eigen 'dáárom niet'. Er bestaat immers niet zoiets eenvoudigs als waarom en daarom. (p. 103)

In de vorige paragraaf besprak ik drie vormen van engagement: berusting, aanvaarding na heroriëntatie en daadwerkelijke verandering van de situatie. Hans Erkelens kiest voor de tweede, Esther voor de eerste mogelijkheid -en wel de zelfmoorddie de meest extreme vorm van berusting is. Dat het voor haar geen opwelling maar een bewuste keuze is, blijkt uit het volgende citaat:

Ze was hier [op de hotelkamer] vrijwillig en ze zou hier vrijwillig kunnen weggaan. [...] Dit is het enige, dat ik ooit werkelijk gewild heb. (p. 104)

\section{De kwade trouw}

De mens verdraagt zijn vrijheid niet, zo stelt Sartre. De poging van de mens om zijn eigen vrijheid te ontkennen noemt Sartre mauvaise foi of kwade trouw. In het werk van andere existentialisten wordt deze leefwijze gekarakteriseerd als 'mythische dommeling' (Jaspers) of 'Zijnsvergetelheid' (Heidegger). ${ }^{4}$ Het 'Men' - een term van Heidegger voor de massa- is hier een typerend voorbeeld van. Het bestaan van de

4 zie: H. van Stralen, Beschreven keuzes. Een inleiding in het literaire existentialisme. Leuven-Apeldoorn 1996: 19 
massamens is een anoniem bestaan. Hij leeft niet vanuit zijn eigen ideeën en opvattingen, maar is de exponent van het gemeenschappelijke: hij bevestigt wat iedereen zegt, wenst en doet. ${ }^{5}$

Van Stralen noemt drie vormen van kwade trouw, die elkaar gedeeltelijk overlappen. Allereerst het ontkennen van bepaalde gevoelens of impulsen. Dit resulteert in een angstige vlucht voor de spontaniteit van het pre-reflexieve bewustzijn. In L'être et le néant noemt Sartre als voorbeeld een vrouw die in een café begint te flirten met een van de mannelijke gasten, terugschrikt voor het mogelijke gevolg daarvan en vervolgens afhaakt. ${ }^{6}$

Ten tweede het vastleggen van deze spontaniteit. Een voorbeeld is de mens die blijft steken in zijn verdriet. Zijn aanvankelijk spontane emotie wordt als het ware gefixeerd om het inslaan van nieuwe wegen te ontlopen. Een ander voorbeeld is de mens die meent iets te moeten zijn, aangezien hij zichzelf daardoor gevangen heeft gezet in een stereotype beeld waaraan hij meent te moeten voldoen ten koste van andere gevoelens of ideeën. Ten slotte ontkent ook de mens die zich een Taak stelt en zich dus concentreert op slechts één handeling het geheel van mogelijkheden die tot zijn beschikking staan. Sartre spreekt in dit geval van de esprit de sérieux. De derde vorm van kwade trouw vindt men in die gevallen, waarin iemand zijn persoonlijke vrijheid ontkent, maar die vrijheid wel buiten zichzelf erkent. Hij kan dan bijvoorbeeld geloven in de almacht van God of zich onderwerpen aan de vrijheid van iemand anders. Iemand kan ook zijn vrijheid en verantwoordelijkheid ontvluchten door deze in zelfgekozen systemen te fixeren.

In de roman Paspoort yoor niemandsland komen diverse representanten van de kwade trouw voor. Ik laat enkele voorbeelden de revue passeren. De eerste vorm, het ontkennen van bepaalde gevoelens en impulsen, komt het duidelijkst naar voren in de figuur van Jacques de la Rive, één van de bezoekers van de Olympus. Hij is sinds tien jaar getrouwd met Connie, die er een vrij liefdesleven op nahoudt, zowel met mannen als met vrouwen. De la Rive besteedt veel zorg aan zijn kleding, onder andere om uit te dragen dat hij een heer van stand is. De familie van Connie wil niets met hem te maken hebben, zijn gesprekken over Metternich of de zeilvaart rond de Kaap in de 17de eeuw worden door hen afgedaan als 'geouwehoer'. Er wordt een zeker verband gesuggereerd tussen de promiscuiteit van zijn vrouw en zijn afkeer van lichamelijkheid. Die afkeer uit zich op verschillende manieren. Hij voeit zich al vies als het buiten te warm is, zweten is blijkbaar een te duidelijke manifestatie van zijn lichamelijk bestaan. Sex acht hij een animale drift, waar een beschaafd heer als hij zich niet aan overgeeft. Door zijn afkeer kan hij zijn lichaam. en dat van zijn vrouw alleen nog maar als Körper ervaren:

5 zie R.C. Kwant, Fenomenologie van de taal. Utrecht/Antwerpen 1963:129

6 zie: Jean-Paul Sartre, Being and Nothingness. A Phenomenological Essay on Ontology (vertaling: Hazel E. Barnes). New York 1984: 96-98 
Ze moet maar doen wat ze niet laten kan. Ben niet zo. lk ben tenslotte geen beest. Katten in de tuin vroeger, thuis. Blazen, krols geschreeuw. Ik niet. Weerzinwekkend dat gekronkel van naakt vlees tegen je aan. Het hindert me niet. Het kon alleen wel een beetje discreter. (p. 39)

Zijn 'kwade trouw' bestaat er niet alleen uit, dat hij bepaalde gevoelens en impulsen ontkent, maar ook dat hij zijn aversie tegen lichamelijkheid heeft gefixeerd. De impulsen van het pre-reflexief bewustzijn ervaart hij niet als een integraal onderdeel van hemzelf, maar als iets waar hij zich voor af dient te sluiten. Door te vluchten in een veresthetisering van zijn bestaan ervaart hij zijn lichaam niet meer als Leib, alleen nog maar als Körper, als een object dat zo esthetisch mogelijk omhuld dient te worden. In dit beeld past ook het madonna-hoersyndroom, dat tegelijkertijd verbonden is met De la Rive's standsbewustzijn: beschaafde dames doen niet aan sex, dat is iets wat gereserveerd is voor prostituees uit de achterbuurten:

Ze [Connie] doet maar. Moet maar leren dat ze met een heer getrouwd is en niet met een dier. Als je heel jong bent interesseren dergelijke dingen je nog. Gewoon nieuwsgierigheid natuurlijk. In mijn studententijd ging ik wel met jaargenoten de achterbuurten in. Dat is tot daar aan toe. Die vrouwen zijn er voor. Toch smerig ook daar. Nergens een behoorlijke badkamer. De meeste van die vrouwen spraken plat. (p. 43)

Hoewel hij door zijn verfijnd en vrouwelijk aandoend uiterlijk vaak voor een homoseksueel wordt aangezien, is hij dat niet. Maar hij heeft door zijn afkeer van lichamelijkheid geen heteroseksuele contacten meer, zoals uit bovenstaand citaat blijkt. Hij is waarschijnlijk een 'nomo', een term die Warmond gebruikt in het gedicht 'Dag dode dichter':

H.L. Mencken sprekend over de baardman Whitman betwijfelt of het waar is wat men vertelde (dat hij zoveel buitenechtelijk kroost verwekt had) en zelfs (wat men eveneens zei) dat hij de Griekse beginselen in het Amerikaans vertaalde ('all hooey'- volgens Mencken)

in een brief aan Edgar Lee Masters schrijft Mencken dan ook: 'He was really probably a NOMO' 
eerst lach je daarom maar daarna

stemt het voornamelijk droevig

als je bedenkt

hoeveel je er kent en hoeveel

je kennissen er dan nog kennen:

allemaal samen een proefschrift

of een studie-weekend waardig. ${ }^{\text {? }}$

Het anti-vitalisme van De la Rive uit zich niet alleen in zijn afwijzing van lichamelijkheid, maar ook in het cultiveren van zijn heer-zijn. Hij heeft zich als het ware gefixeerd in elegante conversatie, die overigens door niemand geapprecieerd wordt, en in een dandy-achtig uiterlijk. Dat getuigt van mauvaise foi. Hierdoor wordt hij door anderen niet als een subject ervaren. Als hij tijdens een gesprek weer eens. benadrukt dat hij tenminste een heer is, raakt Hans zo geïrritteerd

dat hij besloot niet langer mee te helpen -zelfs niet uit beleefdheid- aan het overeind houden van het standbeeld waar de ander al die fraaie kleren omheen gedrapeerd had. (p. 36)

De la Rive wordt door de andere personages niet au sérieux genomen. Hij pretendeert een subject te zijn, terwijl hij zichzelf door zijn anti-vitale trekjes eerder tot een object maakt. ${ }^{8}$ Ook zijn ijdelheid en zelmisleiding maken hem belachelijk. Warmond makt hier gebruik van een komisch procédé. Telkens wanneer mensen met een bepaald stopwoord of eigenaardigheid ten tonele verschijnen kan er een komisch effect ontstaan. Dit procédé staat bekend als mechanisering. ${ }^{9}$

De mawaise foi neemt in Warmonds roman ook nog andere vormen aan. Zo zijn de ouders van Hans typische representanten van de massamens. Door haar angst voor het oordeel van god, maar vooral voor dat van de buren, kortom door zich te conformeren aan de burgerijke moraal perkt zijn moeder haar persoonlijke vrijheid in. Zijn vader wordt door Hans gekarakteriseerd als een bekrompen kleinburger, die zich laat voorstaan op dingen die hij misschien had kúnnen doen, maar niettemin nooit gedaan had. In dit geval is er sprake van een negatieve of afwezige handeling, een belangrijk existentialistisch motief. Zijn vader is een principeloze opportunist, zoals blijkt uit zijn houding tijdens de oorlog. Hij gaat duidelijke keuzes uit de weg, iets wat getuigt van kwade trouw:

En hij verlangde eerbied voor het feit dat hij in de oorlog niet 'fout' geweest was, al was dat ook weer een zuiver negatieve verdienste, want de programma's

7. uit: De groeten aan andersdenkenden. Amsterdam 1970:20

8 zie John Morreall, 'Humor.' In: Gordon 1999: 188-191

9 zie $\mathrm{H}$. van. den Bergh, 'Mechanisering -de lach als levensteken.' In: Konstanten in de komedie. Een onderzoek naar komische uerking en envaing. Amsterdam/ Antwerpen 1972: 118-133 
van de Engelse zender en de uitzendingen van Max Blokzijl hadden zijn gelijke belangstelling gehad. Je moet iets altijd nan twee kanten bekijken. Ze liegen over en weer. Je moet je niet laten lijmen door propaganda; alle partijen hebben ook wel iets goeds. Hij had nog beter overtuigd N.S.B.-er kunnen zijn, dan wist je waar je je tegen verweren moest $[\ldots]$ (p. 118)

Iemand die de burgerlijke fatsoensnormen aan haar laars lapt, is Esther Engelrijk. $\mathrm{Zij}$ laat de impulsen van het pre-reflexieve bewustzijn toe door te vrijen met wie ze wil en creëert zo haar eigen persoonlijke vrijheid, althans op sexueel gebied. Uiteindelijk blijkt dat niet bevredigend te zijn. Haar gedesillusioneerd zijn wordt gefixeerd in cynisme, dat te omschrijven is als gestolde teleurstelling. Deze fixatie en haar keuze voor zelfmoord getuigen van kwade trouw, omdat zij hiermee aangeeft geen vertrouwen meer te hebben in haar handelingsvrijheid, in de mogelijkheid haar situatie te veranderen.

Tenslotte is ook Kasper Wever, Eva's man, een representant van de kwade trouw en wel van de esprit de sérieux. Als hij al doorheeft dat zijn vrouw doorlopend allerlei vriendjes heeft, dan laat hij daar niets van merken. Hij concentreert zich slechts op één Taak: zijn worstfabriek zo winstgevend mogelijk maken. Zijn vernauwde en. mechanische manier van leven wordt scherp gepersifleerd door 'professor' Kien, één van de bezoekers op Eva's feestjes:

Als niet alleen een biologische sóórt, maar ook een individu zou evolueren naar een vorm die het best aangepast was aan zijn manier van leven, zou een mens als Kasper 's morgens een bordje beursberichten moeten eten, hij zou tegelijk met zijn excrementen een rekening moeten uitscheiden waarop de onderhoudskosten van zijn mechanisme over een etmaal gespecificeerd zouden zijn en hij zou tussen zijn schouders een kasregister of een electronische rekenmachine moeten dragen in plaats van dit hoofd. (p. 88)

\section{De authentieke buitenstaander}

De authentieke buitenstạandẹ is hẹt romanpersonage dat in zijn zoektocht naar authenticiteit zijn eigen waarden wil scheppen. Kenmerkend is, dat deze romanfiguur zich afzet tegen de burgerlijke moraal van de massamens. In tegenstelling tot de modernistische held wijst hij onthechting af en kiest voor de gemeenschap. ${ }^{10}$

Hoewel in Warmonds roman diverse personages zich niet wensen te conformeren aan de burgerlijke fatsoensnormen, met name ten aanzien van sexualiteit, vraag ik me af of dit gegeven voldoende is om hen als authentieke buitenstaander te typeren. Zowel Bert, Connie als Eva leiden een promiscue leven, maar doen dit wel binnen de veilige setting van een huwelijk en dankzij een partner die deze levenswijze toestaat (Jacqueline), tolereert (Jacques de la Rive) of niet opmerkt (Kasper Wever). Aan de ene kant kun je het gedrag van Connie en Eva zien als een persoonlijke

10 zie: H. van Stralen 1996: 66 
revolte tegen de maatschappelijke en morele codes die aan vrouwen opgelegd worden, aan de andere kant is er sprake van mauvaise foi, omdat zij vluchten in vluchtige erotische contacten zonder hun situatie wezenlijk te veranderen.

Ook het personage van Bert maakt zich schuldig aan kwade trouw door een dubbele moraal te hanteren. Hij heeft kritiek op de vele vriendinnen van Hans en houdt een prachtig verhaal over het belang van liefde boven dat van erotiek, maar via de figuur van Esther komt de lezer te weten dat hij zélf regelmatig vriendinnen heeft, terwijl Jacqueline, zijn vrouw, op traditionele wijze de liefdevolle en verzorgende figuur op de achtergrond is.

De moderne roman bevat vaak een cynische kijk op het huwelijk, iets wat niet alleen voor dit genre geldt, maar ook voor oudere genres als boerten, operettes, vaudevilles, sprookjes en komedies, waarin de echtgenoot een klassiek lachwekkend personage is. In existentialistische termen is een verhouding gelukkig, als er sprake is van 'la mise en commun de deux existences autonomes, non une retraite, une fuite, un remède'. " De mauvaise foi openbaart zich als de man een vrouw neemt om haar te beschermen of als de vrouw trouwt om een eind te maken aan haar gevoel van onveiligheid en het kindvrouwtje speelt, de zogenaamde femme-oiseau, het uit het nest gevallen vogeltje dat beschermd moet worden. Ook het huwelijk met een rijke partner valt onder de kwade trouw, als dit impliceert dat de vrouw zich daardoor ontslagen voelt van het nemen van belangrijke beslissingen, waardoor zij kan leven aan de oppervlakte, licht en zorgeloos. ${ }^{12}$ Dit laatste geldt zowel voor Eva als voor Connie.

Ook de hoofdfiguur Hans Erkelens komt mijns inziens niet in aanmerking voor het predikaat 'authentieke buitenstaander'. Hij heeft weliswaar afstand genomen van het burgerlijke milieu waar hij uit komt, maar door Bert op een voetstuk te zetten en in hem een richtlijn te zien ondermijnt hij zijn eigen vrijheid van handelen. Even lijkt het erop dat hij zich van zijn leermeester heeft losgemaakt door toch een relatic aan te gaan met Eva, maar aan het eind van de roman kiest hij weer voor zijn vriend.

Het enige personage dat in Paspoort voor niemandsland enigszins de authentieke buitenstaander representeert is Esther Engelrijk. Ze overtreedt op diverse niveaus de burgerlijke fatsoensnormen: ze leidt een promiscue leven, vrijt met zowel mannen als vrouwen, wordt bewust ongehuwd moeder -in de jaren vijftig nog een groot taboe- en overtreedt vervolgens een krachtige moedercode: als ze er na acht maanden achterkomt dat het moederschap haar leegte niet op kan vullen staat zij haar zoon af aan haar kinderloze zus.

Haar uiterlijke presentatie kan sommige mensen op het verkeerde been zetten. Als Jacques de la Rive haar op een middag bij hem thuis aantreft - zij is evenals zijn vrouw in badjas gehuld- concludeert hij dat er geen sprake kan zijn van een sexuele verhouding, aangezien Esthers uiterlijk niet congrueert met het prototype van de

11 Hélène Nahas, Lu femme dans la littcrature existentielle. Parijs 1957: 88

12 Nahas, 1957: 88 
lesbienne. In onderstaand citaat komen via De la Rive als focalisator twee stereotype vrouwenbeelden naar voren: dat van de sexueel verleidelijke en verleidende heterosexuele vrouw en dat van de sexueel afstotende mannelijke lesbienne:

Zag er trouwens ook niet uit of ze voor vrouwen voelde. Décolleté, hoge hakken, fraai kapsel. [...] Zulke vrouwen zagen er toch anders uit? Zware brillen. Afschuwelijk onelegante sportschoenen. Molières, ja. Van die dikke zolen. Mantelpakken. Pantalons soms. (p. 41)

Esthers nonconformisme en autonomie uiten zich niet alleen in haar gedrag maar ook in haar taalgebruik. Nadat ze Hans over haar leven heeft verteld schakelt ze ineens over op het bluesregister. De door haar zelf geschreven tekst, die qua inhoud geënt lijkt te zijn op de tragische teksten van Billy Holliday of Bessie Smith, bevat ook een paar taalelementen die aan Schots-Engelse liedjes ontleend zijn, zoals 'laddy' en de constructie in de zesde regel ('ne'er a ane hae I' betekent 'never a one have I'), waardoor je een merkwaardige vermenging krijgt van blues en folk. Teksten uit beide muziekgenres gaan overigens vaak over het verlangen naar de onbereikbare ander. Door de registervermenging stijgt het thema van Esthers liedtekst boven persoon, tijd, cultuur en etniciteit uit. Deze tekst lijkt eenvoudig, maar lat zich door allerlei dubbele bodems niet gemakkelijk vertalen:

Gin a body, meet a body, comin' throu' the rye, gin a body, kiss a body, need a body cry?

5. every laddy has her laddy

ne'er a ane hae I

gin a body, meet a body,

comin' throu' the rye ... (p.76)

'To gin' betekent onder andere 'strikken', 'in de val lokken'. Het woord 'body' betekent hier waarschijnlijk meer dan alleen maar lichaam. Een 'body' is een sexueel aantrekkelijk meisje of jonge vrouw met een goed figuur. Vanaf midden jaren veertig werden actrices, zangeressen en filmsterren The Body genoemd door columnisten, journalisten en het grote publiek. ${ }^{13}$ Het is opmerkelijk dat er in de liedtekst alleen maar naar 'body' wordt verwezen. Meestal komt dit woord in dit soort teksten voor in combinatie met 'soul'. De woorden 'body and soul' verwijzen naar een geliefde met wie het zowel sexueel als emotioneel en geestelijk klikt. De uitdrukking is waarschijnlijk ontleend aan het lied. Body and soul, geschreven in 
1930 en inmiddels een klassieker in het jazzrepertoire. ${ }^{14} \mathrm{Ik}$ citeer het eerste couplet:

\author{
My heart is sad and lonely \\ For you I sigh, for you, dear, only. \\ Why haven't you seen it? \\ I'm all for you, Body and Soul! ${ }^{15}$
}

In deze song verlangt het lyrisch subject naar de totale verbinding, zowel lichamelijk als emotioneel en geestelijk. Voor Esther is erotiek een middel om haar controlerende rationaliteit uit te schakelen, zoals in een van de voorafgaande paragrafen beschreven is. Ze kan zich echter niet verliezen in een ander. Ze is er, naar eigen zeggen, volstrekt niet bij betrokken. Het is alsof ze op die momenten naar een film kijkt. Ook hier wordt de filmmetafoor gebruikt om een vervreemdende ervaring te visualiseren. Esther geeft alleen maar haar 'body' en niet haar 'soul', terwijl ze op haar beurt bij anderen geen 'soul' vindt. Hier wordt een existentialistisch thema zichtbaar. In de fenomenologie wordt sexualiteit niet gezien als een typisch lichamelijke functie of als een chemisch automatisme. $\mathrm{Ze}$ is daarentegen innerlijk verbonden met het gehele kennende en handelende zijn. Het isolement, dat ontstaat door lichaam en geest te scheiden, kan door de erotiek doorbroken worden. Esther is echter niet in staat om haar controlerende rationaliteit volledig uit te schakelen, behalve misschien indertijd bij haar ex-geliefde Karin. Toch verlangt ze ernaar. Juist omdat de door haar verwachte of gewenste verbondenheid uitblijft, voelt ze zich vervreemd.

In het tweede couplet van haar lied speelt Esther een interessant spel met genderaanduidingen. Intrigerend is de vijfde regel: "every laddy has her laddy". ${ }^{16}$ Je zou hier in eerste instantie verwachten: 'every laddy has his laddy' of 'every laddy has his lassie'. De combinatie van een mannelijk woord (laddy) met een vrouwelijk: verwijswoord doorbreekt op verrassende wijze een taalkundige gendercode, waarin deze combinatie uitgesloten is. In tweede instantie valt op dat Esther zich niet iden-tificeert met een vrouwelijke positie, anders zou het tweede couplet aldus beginnen: 'every lassie has her lassie/laddy' : Ze ziet zichzelf als een jongen op vrij-ersvoeten, alleen is zij een "laddy without her laddy". Mannelijke en vrouwelijke, hetero- en homoseksuele categorieën lopen in deze liedtekst door elkaar heen en. vermengen zich, zoals ook al bleek uit. Esthers gedrag, dat niet congrueerde met de voor vrouwen geldende fatsoensnormen. Mannelijk of vrouwelijk, hetero- of homoseksueel, het zijn voor haar irrelevante aanduidingen, in ieder geval begrippen die zij loskoppelt van de traditionele sekseaanduidingen.

14 informatic ontleend aan Wentworth/Berg Flexner 1968

15 tekst van Edward Heyman, Robert Sour en Frank Eyton; muziek van John Green

16 de vraag doet zich voor of 'laddy' hier een verbastering is van 'lady', maar in Wentworth/Berg Flexner 1968 wordt deze mogelijkheid niet genoemd. 
Die vermenging van allerlei categorieën -mannelijk en vrouwelijk, hetero en homo- is ook terug te vinden in andere personages. Volgens Hans kan geen enkele vrouw hem bieden wat de vriendschap met Bert hem biedt:

Als Bert hem ooit opgebeld had en gevraagd onmiddellijk te komen, dan zou hij ook onmiddellijk gegáán zijn, al lag hij met iemand in bed! Jaap had eens gezegd: Als Bert een vrouw was geweest, was dát je grote liefde geworden ... (p. 16)

Hoewel het anderen opvalt, dat zijn vriendschap met Bert enige homo-erotische trekjes vertoont, is er volgens Hans alleen maar sprake van een typische mannen-vriendschap:

gebaseerd op een volledig wederzijds vertrouwen en een volledige wederzijdse zekerheid dat ze op elkaar konden rekenen. Het was een vorm van vriendschap zonder reserve en zonder risico, die met geen enkele vrouw mogelijk was. (p. 16)

Ook Jacques de la Rive is een 'mengfiguur'. Op basis van zijn uiterlijk zijn mensen geneigd verkeerde conclusies te trekken:

Dat overdreven verfijnde en modieuze element in zijn verschijning was er ook de oorzaak van dat oppervlakkige beschouwers hem bij de eerste aanblik al indeelden in een categorie waar hij niet thuishoorde, omdat zijn geëffimineerdheid zich uitsluitend tot excessen in de zorg voor zijn uiterlijk beperkte. (p. 34)

Terug naar Esther. Haar autonomie komt niet alleen naar voren in haar gedrag maar ook in haar visie op zelfmoord. In een monologue intérieur bekritiseert ze het verlangen naar oppervlakkige antwoorden op de vraag: waarom? Zij stelt hier een minder voor de hand liggende vraag tegenover: waarom niet? Deze Umwertung van de heersende moraal heeft een ontregelend effect:

De meeste mensen willen alleen het 'waarom' weten, omdat ze dan zelf de mogelijkheid van zich afgeschoven hebben. Dan kunnen ze zeggen: Weet je waarom? Hij of zij had een ongelukkige liefde. Of, hij of zij had een ongeneeslijke ziekte, of speelschulden, of een misdaad op zijn geweten. Dáárom! Als je op zo'n vraag naar het waarom zou antwoorden: 'Waarom niet?', dan zouden ze onzeker worden, dan zouden ze gaan twijfelen aan het goed recht van hun eigen 'dárom niet'. Er bestaat immers niet zoiets eenvoudigs als waarom en daarom. (p. 103) 


\section{Gesloten ruimtes}

Een belangrijk motief in het literair-existentialisme is dat van de gesloten ruimtes, een bekend voorbeeld daarvan is de hel in Huis clos (1944) van Sartre. In dit toneelstuk krijgen de personages de kans uit de hel te ontsnappen, maar ze maken geen gebruik van hun handelingsvrijheid. Zo'n beperkte ruimte -hel, kelder, cel, hotelkamer- vormt de setting waarin de existentiële strijd tussen keuzevrijheid en (zelf)beperking zich afspeelt, de strijd met zichzelf, met de ander of met de geinternaliseerde ander. Deze ruimtes visualiseren als het ware het op zichzelf teruggeworpen zijn van het romanpersonage..

In Paspoort voor niemandsland wordt de existentiële strijd gestreden op pensionkamers en in hotelkamers, allebei ruimtes die de beperktheid van iemands leefruimte accentueren. De eerste crisis van Hans vindt plaats op zijn pensionkamer, waar hij tegen Jaap, zijn jeugdvriend, zijn angsten uitschreeuwt. De stilte en de duisternis van de nacht benadrukken zijn existentiële eenzaamheid. Later, als Eva hem bezoekt, is zijn pensionkamer de ruimte waar hij de strijd aangaat tussen controlerende rationaliteit en de impulsen van het pre-reflexieve bewustzijn. Na zijn bezoek aan Eva in Biarritz beseft Hans dat hun relatie niet meer levensvatbaar is. In een Parijse hotelkamer wordt hij geconfronteerd met zijn echec. Hij beseft dat hij Eva als paspoort voor het land der levenden kwijt is en dat hij het nu op eigen kracht zal moeten doen.

De gesloten ruimte is ook belangrijk in verband met het personage Esther Engelrijk. De achtergrond van haar existentiële strijd wordt zichtbaar tijdens het verhaal dat zij aan Hans vertelt, als ze hem op zijn kamer bezoekt. Haar zelfmoord, die ze al min of meer bij Hans heeft aangekondigd, vindt plaats in een hotelkamer.

Opvallend is de verbinding van het motief van de gesloten ruimte met het spiegelmotief. Dit is met name het geval in de passages waarin Hans Erkelens en Esther Engelrijk zich in een existentiële crisis bevinden. Vaak wordt de ruimte verder gereduceerd, verengd tot wat in de spiegel zichtbaar is en dat is meestal het personage zelf. Deze close-up techniek accentueert, zeker in combinatie met het motief van de gesloten rumte, de niet meer te ontlopen confrontatic met zichzelf. De twee hotelkamerscènes weerspiegelen de existentiële keuzes die daar uit voortvloeien: Esther kiest voor de dood, Hans kiest voor het leven.

Het motief van de gesloten ruimte visualiseert in Warmonds roman ook nog op een andere manier de beperking van het menselijk bestaan. De winkel in huishoudelijke artikelen van Hans' ouders bijvoorbeeld staat symbool voor het kleinburgerlijke milieu dat zij representeren. Met name de wasteil en het keukentrapje fungeren als een soort iconen voor de kleingeestigheid van hun milieu:

[...] dat winkelțe, waar ze als het ware de symbolen van de kleinburgerlijke aanpassing en onderdanigheid verkochten: wasteilen voor mensen zoals zijn ouders, die geen badkamer hebben, maar principes huldigen die alleen in 
gemeenplaatsen uitgedrukt kunnen worden [...]. Keukentrapjes verkochten ze, keukentrapjes om hogerop te komen, 8 of 12 treden, een parodie op de maatschappelijke ladder. (p. 118)

De bekrompenheid van een kleinburgerlijk bestaan wordt ook zichtbaar in de beschrijving van huizen in de buurt van Hans' oude H.B.S. De techniek van het inzoomen (van H.B.S.-gebouw naar woonhuis, voortuintje, stoepje, grassprietjes, hekje, gevel) roept een benauwende sfeer op:

De Dr. Kappermanstraat, waar de H.B.S. stond als een gore steenvloek tussen de kleinere bastaardvloeken van de tegen het gebouw aanleunende woonhuizen, waren de voortuintjes het gekst. Dat wáren geen voortuintjes; deze begroeide stoepjes, waarop een telbaar aantal grassprietjes tierde, omzoomd door een hekje, zo armetierig klein en wankel, dat zelfs een H.B.S.-er er niet tegenaan zou hebben kunnen leunen zonder gevaar met hekje en al achterover te slaan. En dan nóg maar tot de gevel van het huis, want in het tuintje zelf was niet eens ruimte genoeg om languit te vallen. (p. 7)

De sfeer van onpersooniljkherd en stilstand in dit soort buurten vormt een scherp contrast met het leven en de dynamiek van de binnenstad. Over de straat waar zijn chirurg woont, die vergelijkbaar is met de HBS-buurt, denkt Hans:

Het was een onpersoonlijke wijk. Allesbehalve geschikt om je weer met het leven -of met wat dan ook- vertrouwd te maken. Dat zou in de binnenstad gemakkelijker gaan. In de drukte en het lawaai van al die mensen die haast hadden en al dat verkeer dat haast had ... (p. 20-21)

Aan het eind van het boek bevindt de hoofdfiguur zich weer in de HBS-buurt. De cyclische structuur heeft samen met de techniek van het open einde een beklemmend effect: Hans is weer terug bij af, opnieuw wordt hij voor een existentiële keuze gesteld. Dit keer kan hij niet meer terugvallen op zijn inmiddels overleden mentor en vriend. De metaforische betekenis van de hekjes vóór de huizen verandert op dat moment, ze krijgen er een dimensie bij. Niet meer symboliseren ze alleen de beperktheid van een kleinburgerlijk bestaan, zoals in het begin van de roman, maar ook de mate waarin je op iemand terug kunt vallen:

Mensen zijn als hekken. Tegen sommige kun je aanleunen om steun te zoeken. Andere zijn voorzien van scherpe punten of glasscherven, alsof ze bang zijn dat je erop zou gaan zitten en als je er tegenaan zou leunen vallen ze om, zoals deze hekjes waarschijnlijk. Hij stak de straat over en leunde met zijn volle gewicht tegen een tuinhekje, dat zuigend meegaf. Het was een walgelijk gevoel, dat hem physiek misselijk maakte. (p. 194) 
De voorlaatste regel van bovenstaand citaat evoceert de existentiële eenzaamheid van de hoofdfiguur. Hij is zijn houvast kwijt, wat letterlijk resulteert in een gevoel van nausée.

\section{Geseculariseerde invulling van christelijke begrippen}

Karakteristiek voor het literair-existentialisme is het opnieuw interpreteren van christelijke begrippen binnen een geseculariseerd kader. ${ }^{17}$ Deze begrippen krijgen een aardse invulling. De 'hel' bijvoorbeeld duidt de onleefbare situatie met de ander aan. Ook het zondebegrip krijgt een aardse invulling: de onherstelbare fout tegen de medemens.

In Paspoort voor niemandsland komt dit gegeven een aantal keren voor. Elementen uit de bijbel, zoals de lijdende Christus, het verraad van Petrus en het scheppingsverhaal, krijgen een aardse, geseculariseerde invulling. De nacht vóórdat Hans van zijn chirurg te horen zal krijgen of zijn ziekte dodelijk is of niet, heeft hij zijn jeugdvriend Jaap gevraagd om met hem te waken. Jaap valt echter tot woede van zijn vriend in slaap. Dit roept reminiscenties op aan Jezus in de Hof van Getsemane (Matth. 26: 36-46), die aan de vooravond van zijn dood door zijn slapende leerlingen aan zichzelf werd overgelaten. Als Hans terugdenkt aan zijn operatie ziet hij zichzelf als op een plaatje op de operatietafel liggen, de armen opzij gestrekt 'als voor een kruisiging'. Ook de volgende herinnering sluit daarbij aan:

Geluidloos vormden zijn lippen een woord. De ogen verdwenen uit zijn gezichtsveld om plaats te maken voor een glas water, waar een hand-van Jaap? vain een verpleegster?- een zakdoek in doopte en die op zijn mond legde. Weer een kruisigingsreminiscentie: 'mij dorst'. En weer een plaatje, ditmaal werkelijk gezien, in een kinderbijbel vroeger: 'Eli, Eli, Lama Sabachtani!' ... (p. 25-26)

De lijdende Christus is hier geseculariseerd tot het exemplarische beeld van de lijdende mens, die zich volledig op zichzelf teruggeworpen voelt in een godverlaten existentiële eenzaamheid, zoals aangegeven wordt door de verwijzing naar het 'Eli, Eli, Lama Sabachtani' uit het Mattheusevangelie. De regels zijn oorspronkelijk. afkomstig van Psalm 22, waarvan de eerste strofe als volgt luidt:

Mijn God, mijn God, waarom hebt gij mij verlaten?

Ver van mijn roepen om uitkomst,

Ver van mijn schreien om hulp.

Bij dag roep ik, mijn God-Gij blijft zwijgen,

Bij nacht -en ik word niet gestild! 
God is de grote Afwezige, of in de woorden van Sartre: 'De stilte, dat is God. De afwezigheid, dat is God. God is de eenzaamheid van de mensen.'18

De naar mijn smaak wat al te theatrale associaties met de lijdende Christus worden verder in de roman opgevolgd door verwijzingen naar het verraad van Petrus. Tijdens een gesprek over Esthers zelfmoord, geeft Hans tot drie keer toe ten onrechte een ontkennend antwoord op vragen van Eva. Hij ontkent, dat hij Esther daartoe in staat achtte. Hij ontkent, dat hij haar na die avond in de Olympus nog gezien heeft, terwijl ze hem daarna nog opgezocht heeft en toen al min of meer suggereerde zelfdoding te overwegen. Tenslotte doet hij alsof hij niet weet dat Esther een zoontje heeft. Het verraad van Petrus staat hier voor het verraad van de ene mens door de andere en voor het ontlopen van verantwoordelijkheid, aangezien Hans wel degelijk besefte hoe Esther eraan toe was, maar zijn ogen bewust daarvoor heeft gesloten. Dat gedrag continueert hij, zoals blijkt uit onderstaand citaat, waarin hij zichzelf vergelijkt met Pilatus, die zijn verantwoordelijkheid voor het vonnis van Christus afschoof op de Joden. Bovendien makt de hoofdfiguur zich niet sympathieker door net als Adam in het scheppingsverhaal Eva als zondebok aan te wijzen. De vrouw wordt hier gedemoniseerd, net als in de tijd van de heksenvervolgingen, waarin vrouwen aansprakelijk werden gesteld voor gebeurtenissen waar ze part noch deel aan hadden:

Petrus. De haan. Ik was mijn handen in onschuld. Nee, dat was Pilatus. Wie had er schuld? Niet hij, hij wist er niets van. Hij had er niets van begrepen. Misschien had Eva schuld. Ze hing met onheil samen. Eerst dat met Bert en nu dit met Esther. Een onheilsbode, een moderne heks, zonder bezemsteel en in het tegendeel van lompen gekleed, zonder toverformules, of het moest dat herhaalde 'waanzinnig, zeg!' zijn. (p. 124)

Hoe anders denkt hij over Eva na hun afscheid in de stationsrestauratie, vlak voor haar vertrek naar Biarritz. Als hij op dat moment haar betekenis voor hem overdenkt, doet hij dat in oud- en nieuwtestamentische termen, die een geseculariseerde invulling krijgen. De figuur van Eva staat hier voor de vrouw die de ander door middel van de erotiek in de ban houdt. En passant wordt het scheppingsverhaal herschreven. Uit deze herschrijving blijkt, zoals ook uit andere passages in de roman, dat Eva voor Hans niet zozeer een autonoom persoon is, als wel een functie. $\mathrm{Ze}$ is een middel om zich te kunnen verzoenen met het bestaan:

[...] het zou geen brief worden, maar een zakbijbeltje, behelzende de geschiedenis van een obsessie, een wondergenezing, vanaf het Eden van haar glimlach, over de Exodus van haar ogen tot en met het Laatste Oordeel over een geblokt tafelkleedje. Een scheppingsverhaal, waarin Eva hem niet als rib ontnomen zou 
worden, maar juist toegevoegd. Een zwevende rib. Een rib, die maakte dat hij kon zweven. (p. 148)

\section{Classificatieprocédé}

Een andere karakteristiek van het literaire existentialisme is het classificatieprocédé, dat wil zeggen dat personages een bepaalde ideologie of opvatting representeren. Dit is met name het geval binnen het ethische existentialisme. Van Stralen wijst terecht op de overeenkomsten met het middeleeuwse mirakelspel, waarin allegorische figuren voorkomen als de Dood, de Vriendschap en de Deugd. In La nausée bijvoorbeeld staat de Autodidact voor de serieuze mens die zich op slechts één. Taak richt, terwijl Roquentins ex-geliefde Anny voor de onverschilligheid staat. ${ }^{19}$ Het is duidelijk dat dit classificatiebeginsel een enigszins moralistische achtergrond heeft: op die manier worden de voor- en nadelen van verschillende levensstijlen zichtbaar met de bedoeling de lezer aldus een spiegel voor te houden en tot een keuze te bewegen.

Het nadeel van dit kenmerk is mijns inziens dat het niet specifiek genoeg is. Het is op diverse didactische of moralistisch getinte genres uit verschillende periodes van de literatuurgeschiedenis van toepassing: van sprookjes tot politieke thrillers, van middeleeuwse mirakelspelen tot negentiende-eeuwse historische ideeënromans. Aan de andere kant kun je stellen dat dit kenmerk, zeker in aanwezigheid van de al eerder genoemde criteria, een extra aanwijzing kan zijn om op basis daarvan te bepalen in hoeverre een roman binnen het literaire existentialisme is te plaatsen. Ook Warmond maakt in haar roman gebruik van het classificatieprocédé. In deze paragraaf bespreek ik enkele romanfiguren die op een wat geprononceerdere manier dan de overige personages een morele positie representeren. Allereerst Jaap Viergever, de jeugdvriend van de hoofdfiguur. Hij staat voor de angstige opportunist, die bang is ergens persoonlijk bij betrokken te raken. In een snackbar vraagt hij Hans of er binnenkort weer antisemitisme komt, aangezien hij een joodse vriendin heeft. Als Hans wil weten waarom hij die vraag stelt, krijgt hij het volgende antwoord:

'Waarom? Nou, omdat ik dacht: stel, dat ik met dit meisje trouw en er komt weer een periode van jodenvervolging, dan zou ik dus ook in een kamp terechtkomen, als ik haar man wạs.' (p. 120)

Op het moment dat hij hem fel van repliek dient, dringt het ineens tot Hans door dat hij niet zijn eigen visie maar die van Bert aan het napraten is. Het is de ander, in dit geval Jaap, die hem een spiegel voorhoudt: hij beseft dat hij wel eens net zo opportunistisch zou kunnen handelen als zijn jeugdvriend.

19 zie H. van Stralen. 1996: 121 
Een ander voorbeeld van het classificatieprocédé is Delvette Braning, exportmanager van Eva's echtgenoot Kasper Wever. Hij representeert de reactionaire kapitalist en de conservatieve anti-socialist. Zijn vertrouwen in de dekolonisatie, die met name in de jaren vijftig op gang kwam, is op basis van racistische en economische motieven gering:

Je moet ze vooral veel leren, dat zwarte geteisem. Of we uit Indië geen les hebben kunnen trekken! Die bavianen hebben voor het eerst van hun leven schoenen aan en dan denken ze dat ze een land kunnen besturen! En wie heeft er de welvaart gebracht? Wie heeft er fabrieken gebouwd, mijnen gegraven, olie geboord? Wie hebben in Indië suikerraffinaderijen gesticht? Als wij er niet geweest waren, vraten die zwarten het suikerriet rauw, net als de gorilla's. Geef ze een bril en een paar schoenen en ze denken dat ze de Europese cultuur in hun zak hebben! Als je goed koloniseert moet je de inboorlingen uitroeien, net als de Spanjaarden in Mexico vroeger. Die wisten het wel. Je zou er verdomme Rooms door worden! (p. 91)

Bovendien moet hij niets hebben van de toenemende democratisering in Nederland, waardoor ook mensen uit de arbeidersklasse kunnen doordringen tot de universitaire bovenlaag. Hij spreekt smalend over de universiteit van Rotterdam, waar zijn zoon economie studeert en college krijgt van de zoon van de melkboer en de schoenmaker!

Op hetzelfde feest als waarop Hans de heer Delvette Braning heeft leren kennen ontmoet hij ook de wetenschapper Kien, een stripachtige figuur met een programmatische naam, die, evenals de naam van zijn collega Slijper, doet denken aan die van Dr. Cijfer en Pluizer uit De Kleine Johannes van Frẹderik van Eeden. Kien staat voor de rationele wetenschapper die zich afzet tegen het anti-intellectualistische klimaat in Nederland:

ik geloof niet in menselijke handelingen of relaties, die uitsluitend door gevoelsmatige overwegingen gevoed worden. Dergelijke relaties wemelen van de misverstanden, zijn meestal op een misverstand gebaseerd en gaan daar bijna altijd aan kapot. Maar in een land waar 'intellectueel' een scheldwoord is, wordt het moeilijk iemand van de juistheid van dat standpunt te overtuigen. [...] Maar het gebruik van hersens schijnt -anders dan voor economische of wetenschappelijke doelen- bij de meeste mensen op tegenstand en zelfs verachting te stuiten. Alleen vraag ik me weleens af, waarom dat veelgeprezen, almachtige, alleentegenwoordige gevoel van die anti-intellectualisten hen niet in staat stelt zich te verplaatsen in de gesteldheid van wat zij zelf noemen 'mensen die alles kapot-analyseren'. De waanzin! Wat je kapot-analyseren kan zijn schijnwaarden, façades, maar de analyse van iets werkelijk waardevols levert alleen een aantal waardevolle elementen op, warvan het onderzochte de som is.(p. 87) 
Tenslotte nog twee voorbeelden van het classificatieprocédé. Esther, die de programmatische achternaam Engelrijk draagt, staat voor de mens die uiteindelijk. voor zelfmoord kiest. De lezer kan zelf op basis van de aangedragen elementen bepalen of hij haar argumentatie acceptabel vindt of niet. De programmatische achternaam van De la Rive is al eerder ter sprake gekomen. Bert representeert de vaderfiguur die alles waar hij zelf niet in is geslaagd projecteert op zijn 'zoon', in dit geval zijn leerling Hans. Hij ziet Hans in feite niet als een persoon van vlees en. bloed, maar als iemand die zijn ideaalbeeld moet verwezenlijken. Op het moment dat hij daar niet aan voldoet, laat Bert hem vallen.

\section{Registerwisselingen}

Diverse existentialistische auteurs maken in hun romans gebruik van zowel literaire als filosofische stijlregisters. In een eerder hoofdstuk heb ik aangegeven hoe filosofie en literatuur zich tot elkaar verhouden in met name het existentialisme. Hoewel literatuur volgens Sartre geen illustratie van filosofische ideeën dient te zijn, ontkwam hij daar niet altijd aan. Dat geldt ook voor een auteur als De Beauvoir, bijvoorbeeld in haar roman Le sang des autres (1943), waarin beschouwende passages voorkomen over politiek en kunstenaarschap.

Hoewel je de genoemde registerwisselingen vooral verwacht bij auteurs die een filosofische achtergrond hebben -zoals Sartre, De Beauvoir en Camus-komen ze ook bij andere auteurs voor. Zo ook bij Warmond. Registerwisselingen als de switch naar een vitalistische stijl (p. 23 bijvoorbeeld) of naar het bluesregister (p. 76) komen hier niet voor in aanmerking, omdat ze vooral een stemmingswisseling markeren, maar in een aantal passages schakelt Warmond over van een literaire naar een meer beschouwende stijl. Ze zijn te herkennen aan het generieke gebruik van. het persoonlijk voornaamwoord 'je' en aan generieke aanduidingen als 'de mens' of 'een mens'. Hierdoor ontstaat een generaliserend effect: de opmerkingen worden boven het persoonlijke niveau uitgetild en op een universeler plan gebracht. Soms vindt zo'n registerwisseling plaats in een dialoog, bijvoorbeeld in de -monologische- dialoog van Bert Masson waarin hij op beschouwende wijze over het verschil tussen liefde en erotiek praat. Enkele keren ook in een cursieve passage, die mede door zijn andere lay-out al een stilistische of thematische verandering aankondigt. Een voorbeeld:

Alleen de mens ondergaat de dood als tegennatuurlijk. Het enige dat hij van zijn leven weet is, dat het een doorlopend gevecht is met de dood. Uit vrees afstand te moeten doen, niet van een werkelijk bezit, maar van een antal mogelijkheden, waarvan hij tegelijkertijd heel scherp beseft dat ze wel nooit gerealiseerd zullen kunnen worden. Het enige verschil tussen dood en leven is dat de dood kansloos en dus hopeloos is. Het leven is een moedwillig optisch bedrog. Verdriet en geluk en alle nuances daartussen bestaan alleen bij de gratie 
van het feit, dat je ze in de toekomst kan projecteren. Wanneer je van iets erkent dat er een eind aan komt, begin je er niet aan. Zonder dit perspectivisch zelfbedrog is het onmogelijk om bijvoorbeeld lief te hebben. (p. 192)

Met name in de zeven cursieve passages in Paspoort voor niemandsland vindt er een bijna onmerkbare perspectivische verschuiving plaats: het is niet altijd duidelijk of je als lezer nog de gedachten van de hoofdfiguur volgt of de overdenkingen van een externe verteller. De passages waarin de registerwisseling plaats heeft gaan over het algemeen over de grote existentiële onderwerpen liefde, dood, het maken van keuzes en verantwoordelijkheid. Omdat de inhoud daarvan in diverse paragrafen al aan de orde is geweest, ga ik daar nu niet verder op in.

\section{Receptie van Paspoort voor niemandsland}

De voorafgaande paragrafen laten zien, dat Warmonds roman uit existentialistisch oogpunt buitengewoon interessant is. De vraag doet zich nu voor of het boek ook in literair opzicht geslaagd is. Er zijn enkele punten van kritiek te noemen. De passage waarin de net geopereerde Hans zich vergelijkt met de lijdende Christus is me te theatraal, zoals ik eerder opmerkte. Sommige figuren, Eva bijvoorbeeld, blijven nogal schematisch. Met name de gesprekken met Bert ontaarden regelmatig in politiek-correcte statements. Bovendien heeft het voortdurend ironiseren van gevoelens op een gegeven moment een vermoeiend effect. Ik kan me voorstellen dat niet iedere lezer opgewassen is tegen de overdosis aan zwartgalligheid in het boek.

De roman bevat echter ook passages die in literair opzicht geslaagd zijn: de spiegelscènes, de zelfmoordscène van Esther Engelrijk, de dialogen in de Olympus en het amusante hoofdstuk waarin De la Rive centraal staat. Ook het spelen met categorieën als homo / hetero en mannelijk / vrouwelijk bevalt me.

Na Paspoort voor niemandsland heeft Warmond geen roman meer gepubliceerd. In een interview in NRC Handelsblad van 10 augustus 1979 vertelt ze, dat het boek over thema's gaat die ze niet kwijt kon in haar gedichten. ${ }^{20}$ Bleven er na haar eerste roman te weinig thema's over voor een nieuw boek of kwam Warmond tot de conclusie, dat poëzie voor haar een geschikter medium is? Mocht het antwoord in dat laatste geval 'ja' zijn, dan kan ik daarmee instemmen. Hoewel Paspoort voor niemandsland als debuut interessant is, geef ik de voorkeur aan Warmonds poëzie. Overigens zal in het volgende hoofdstuk blijken, dat met name de cursieve passages in Paspoort voor niemandsland een verhelderend licht werpen op Warmonds poëzie. Hoe werd Warmonds roman ontvangen in de pers en zijn er daarbij verschillen in beoordeling tussen mannelijke en vrouwelijke recensenten? In haar studie Baard boven baard (2001) onderzoekt Marianne Vogel of en in hoeverre er genderspecifieke verschillen in beoordeling zijn van mannelijke en vrouwelijke auteurs door

20 in: Lien Heyting, 'Ik sla niet meer zo hard op tafel.' NRC Handelsblad 10-8-1979 
-overwegend mannelijke- recensenten. Het blijkt, dat genderspecifieke argumenten ertoe kunnen leiden, dat vrouwelijke auteurs kwalitatief lager worden ingeschat dan hun mannelijke collega's. In haar boek noemt Vogel de belangrijkste literaire recensenten, dagbladen en landelijke opiniebladen uit de periode $1945-1960 .^{21}$

In de rest van deze paragraaf staat de vraag centraal in hoeverre Vogels bevindingen ook van toepassing zijn op de manier waarop Paspoort voor niemandsland ontvangen is door de landelijke pers. Ik ga hierbij uit van acht recensies die naar aanleiding van Warmonds roman verschenen zijn. Warmonds boek is weliswaar in 1961, dus net buiten de door Vogel onderzochte periode verschenen, maar er zijn. geen redenen om aan te nemen dat de situatie zo kort daarna ingrijpend gewijzigd is. Warmond wordt door twee van de negen belangrijkste recensenten besproken, namelijk Rico Bulthuis en Jan Greshoff. Recensies van haar boek verschenen in drie van de tien belangrijkste dagbladen (Het Vaderland, Het Parool en NRC) en in één van de vier belangrijkste landelijke opiniebladen, namelijk Vrij Nederland. In het corpus van de door mij onderzochte recensies bevindt zich slechts één deelrecensie, dat wil zeggen een recensie waarin minstens nog één andere auteur wordt besproken. In dit geval is dat Helma Wolf-Catz. Als ik afga op Vogels conclusie, dat het aantal deelrecensies samenhangt met de onbelangrijkheid van iemands literaire positie, kan ik concluderen dat Warmonds werk in die periode serieus wordt genomen.

In Vogels studie komt ook naar voren, dat er drie hiërarchisch geordende literaire referentiekaders zijn: het eerste en laagste is dat van de binnenlandse vrouwelijke auteurs, het tweede en middelste is dat van de binnenlandse mannelijke schrijvers, het derde en hoogste kader wordt gevormd door buitenlandse mannelijke auteurs. Het referentiekader 'buitenlandse vrouwelijke auteurs' ontbrak in de door Vogel onderzochte recensies. In slechts drie recensies wordt Warmonds werk in een literair referentiekader geplaatst. Het personage van Eva heeft volgens Jan Greshoff "iets Marlittachtigs, maar dan onkies bijgekleurd', omdat ze 'in het moderne iets ouderwets' vertoont. ${ }^{22}$ Deze, enigszins cryptische, associatie heeft overigens alleen maar betrekking op Eva, niet op de verdere inhoud en/of stijl van het boek. Rico Bulthuis vergelijkt Warmond wat duidelijkheid, eerlijkheid en a-sentimentaliteit betreft met G.K. van het Reve, W.F. Hermans en Anna Blaman, ook al zijn deze auteurs volgens hem onderling slechts oppervlakkig te vergelijken. Volgens Meta van IJzer is Warmond in de beschrijving van de personages enigszins beïnvloed door Anna Blaman: 'objectief, met een mengeling van ironie en mededogen'. ${ }^{23}$ Renate Rubinstein vergelijkt haar werk in thematisch opzicht met dat van Anna Blaman en Nel Noordzij. Warmonds werk wordt dus, Greshoffs losse opmerking daargelaten, niet alleen in verband gebracht met het eerste, maar ook met het

21 Marianne Vogel, Baand boven baand. Over het Nederlandse literaire en maatschappelijke leven 1945-1960. Amsterdam 2001

22. E. Marlitt is het pseudoniem van de Duitse schrijfster E. John (1825-1887). Zij schreef romans met titels als Het heideprinsesje, De rijksgnavin Gisela en In het huis uan den handelsnaad.

23 M.van IJzer, 'Ellen Warmond. Ontmoeting in proza.' In: Jeugd en aulnur. Brussel 1964, p. 316-319 
tweede referentiekader. Ook dat geeft aan, dat ze niet onderaan de literaire ladder staat.

De reacties op haar roman lopen nogal uiteen. Ze variëren van 'weinig karakteristiek, zelfs babbelend proza' tot 'een uiterst vernuftige èn uitermate gevoelige roman'.

Enkele recensenten hebben problemen met het boek op morele gronden, omdat de romanfiguren 'hinderlijk veel vooral onder de gordel' blijken te leven. ${ }^{24}$ Hoewel Jan Greshoff de roman bewondert, vindt hij met name de vrouwenfiguren (Esther en Eva) 'afschuwelijk' en 'ignobel'. Hij hoopt dat Warmond ook nog eens zal schrijven over andere mensen dan 'vaatdoeken en vuilikken, van machteloze ethylisten, roddelaars en bedzwetsers beneden peil'. Aan de andere kant, en dat is een compliment aan Warmond, geeft hij toe dat de auteur door haar beeldende vermogen dit milieu wel geloofwaardig heeft neergezet. ${ }^{25}$

De meeste recensenten -met uitzondering van Greshoff, die erg enthousiast is- zijn het erover eens, dat de roman goede, interessante en originele stukken bevat, maar als geheel achten ze het boek op grond van overwegend structurele argumenten niet geslaagd. Renate Rubinstein bijvoorbeeld vindt, dat het boek mank gat aan een teveel aan uitleg. Het is te expliciet in de details, bovendien wijst ze op een volgens haar storende vermenging van literaire en psychologische stijlregisters. Zo vindt ze de ruzie tussen de hoofdfiguur Hans en zijn leermeester voortreffelijk beschreven, maar de passage wordt bedorven door een uitleg van de vader-zoonbinding tussen deze twee romanfiguren. Daar staat tegenover dat zij er, in tegenstelling tot veel andere 'eenzaamheidsbeschrijvers', wel in slaagt om aan menselijke verhoudingen 'realiteit te geven'. Andere mensen zijn niet alleen maar spiegels of andere gebruiksvoorwerpen voor de hoofdpersoon, maar mensen die weerstand bieden zonder hem noodzakelijkerwijze te haten. Dat betekent, aldus Rubinstein, dat men met een echte roman te maken heeft. ${ }^{26}$

Ook Beb Vuyk ${ }^{27}$ vindt het teveel aan uitleg een tekort. Opmerkelijk is dat zij Eva's man, de kapitalistische worstfabrikant, als groteske erg geslaagd vindt, terwijl Rico Bulthuis ${ }^{28}$ hem en enkele andere figuren afwijzend eenzijdig en zelfs karikaturaal noemt. Slechts twee recensenten, Vuyk en Rubinstein, wijzen op de homoseksuele verhouding tussen Esther en Karin. Volgens Vuyk suggereert Warmond 'een homoseksuele vriendschapsbinding als mogelijke oorzaak van haar [Esthers] zelfmoord'. Rubinstein merkt op, dat Warmond met Anna Blaman en Nel Noordzij een zekere fascinatie door de homo- en biseksualiteit gemeen heeft,

24 R. Boltendal, 'Romans van Helma Wolf-Catz en Ellen Warmond.' Friese Korric 18-11-1961

$25 \mathrm{~J}$. Greshoff, "'Paspoort voor niemandsland". In roman van E. Warmond zijn intellect en emotie innig vervlochten.' Het Vaderland 14-4-1962

26 Renate Rubinstein, 'Ellen Warmond als prozaschrifster.' NRC 25-11-1961

27 Beb Vuyk, 'Twee boekjes van Ellen. Warmond. Geen paspoort voor de eeuwigheid.' Vrij Nederland 13-1-1962

28 Rico Bulthuis, 'Ellen. Warmond verdwalt met haar Paspoort voor Niemandsland.' Haagsche Courant $28-4-1962$ 
overigens meer suggererend dan beschrijvend, 'waardoor de indruk gewekt wordt dat zulke afwijkingen van gering belang zijn maar vrijwel bij iedereen voorkomen.' Vogel onderscheidt in haar studie vier hiërarchische paren waar het de beoordeling van vrouwelijke en mannelijke eigenschappen betreft, waarbij de laatste eigenschappen hoger ingeschat worden dan de eerste. Eén van die hiërarchische paren is een gevoelsmatige instelling versus een rationele instelling. Warmond scoort voorall op het laatste onderdeel. Twee recensenten valt het namelijk op, dat Warmond haar mannelijke hoofdpersonen van binnenuit weet te tekenen waardoor ze volkomen aanvaardbaar worden. 'Dit getuigt van een bijzonder inlevingsvermogen waarover niet vele vrouwelijke auteurs beschikken', aldus een anonieme recensent. ${ }^{29}$ Volgens Greshoff doorziet Warmond het manvolk oneindig dieper dan de vrouwen dankzij haar 'ongewone intelligentie' (ongewoon voor wie?). Ze heeft een 'onmiskenbare, sterke cerebraliteit' die zij goed weet te combineren met intuitie en gevoel. Het is voor Greshoff 'een raadsel hoe intellect en emotie zo innig dooreengewerkt kunnen worden in een uiterst vernuftige èn uitermate gevoelige roman.'

Slechts enkele recensenten zien een verband met de problematiek van de naoorlogse jeugd met de bekende thema's: doodsangst, eenzaamheid, vervreemding. landerigheid, verveeld-zijn en wanhoop, maar nergens wordt dit thematische cluster in een existentialistische context geplaatst. Pas achteraf, in twee artikelen uit 1984 en 1991, wordt Warmonds roman met het existentialisme in verband gebracht. Vanwege de thematiek van het echec en de daaruit voortkomende zelfverachting plaatst Jan van der Vegt de roman 'in de sfeer van de existentialistische literatuur'. Hij acht invloed van Blaman niet uitgesloten. ${ }^{30}$

Ook Truusje van de Kamp verbindt de roman met existentialistische ideeën. ${ }^{31}$ In haar visie vormt de zuigkracht van het niets een rode draad in het boek, waarmee Warmond aansluit bij Sartres theorie van het niet-zijn dat in het zijn sluipt en bij Heideggers Leben zum Tode. Door de dreiging van de dood komt de tijdservaring onder druk te staan, met als gevolg angst, wanhoop en vervreemding. De vele spiegelscènes geven aan dat de hoofdpersoon op zichzelf teruggeworpen wordt. Alleen. door middel van de erotiek kan hij-weliswaar tijdelijk-ontsnappen aan deze beklemmende situatie, aldus Van de Kamp.

Het moge inmiddels duidelijk zijn, dat het verband tussen Warmonds roman en het existentialisme complexer is dan door Van der Vegt en Van de Kamp in hun artikelen gepresenteerd wordt.

29 ?, 'Ellen Warmond schrijft ook proza. Ellen Warmond: Eeuwig duurt het langst. Paspoort voor niemandsland:'?

30 Jan van der Vegt, 'Ellen Warmond.' in: Kritisch Litenatuur Lexicon, Groningen. 1984

31 Truusje van de Kamp, 'Scheppen in de luwte van de taal. Over Ellen Warmond.' In: Margriet Prinssen en Lucie Th. Vermij, Schrijfsters in de jaren vijftig. Amstendam 1991: 197-208 


\section{Besluit}

Het is opmerkelijk hoezeer Paspoort voor niemandsland zowel formeel als inhoudelijk voldoet aan de criteria voor het literaire existentialisme. Er is een hecht verband tussen inhoud en vorm: fictionele technieken als het gebruik maken van verschillende personage-gebonden focalisators, metafoorpatronen en simultaneiteit weerspiegelen de inhoudelijke thematiek. In een interview met Henk Struyker Boudier (1978) vertelt Warmond, dat ze zich in haar jeugdjaren aangetrokken voelde tot het werk van Sartre. Ze herinnert zich nog levendig hoe Anna Blaman, begin jaren vijftig, reageerde op een stukje proza dat ze haar liet lezen ${ }^{32}$ :

Ik zie haar nog één voor één al die blaadjes opzij leggen. Ik had ook een stukje proza meegebracht. Ik las in die tijd Les chemins de la liberté van Sartre en ik had pas De avonden van Van het Reve cadeau gekregen. Die hadden allebei grote indruk op me gemaakt. Dat proza was dan ook meer van Van het Reve dan van mij en de ideeën waren allemaal van Sartre. Tobbing en loodzware humor. Het was De ochtenden, zei Anna. [...]

Tenslotte zei ze: 'De gedichten wil ik nog wel eens lezen, maar het proza geef ik je terug, want dat is te modernisties om modern te zijn.' Dat vond ik een slag. Toen zei ze: 'Maar troost je, want Sartre zou het geweldig vinden.' ${ }^{33}$

Paspoort voor niemandsland geeft aan, dat Warmond eind jaren vijftig/begin jaren zestig nog steeds grote affiniteit heeft met het existentialistische gedachtegoed. ${ }^{34}$ Het Sartriaanse conflictmodel lijkt in grote lijnen van toepassing op deze roman, maar uit diverse aspecten blijkt, dat dit model alléén niet voldoet. Met name in het personage Hans. Erkelens bestaat er een spanningsveld tussen de 'Sartriaanse' vervreemding enerzijds en het 'Merleau-Pontyaanse' verlangen naar het ervaren van de pre-reflexieve eenheid anderzijds. Voor Hans is die pre-reflexieve ervaring wel degelijk een enkele keer mogelijk, al is dat vooral in de erotiek.

Ook om een andere reden voldoet het conflictmodel van Sartre hier niet. Het ambiguiteitsmodel van Merleau-Ponty verleent aan aspecten als pre-reflexiviteit, lichamelijkheid, vervreemding, de blik, sexuele intimiteit en vrijgheid meer reliëf en diepgang dan het Sartriaanse model.

Rest de vraag of Warmonds roman een specimen is van de esthetische of de ethische variant van het literaire existentialisme. In deze roman staat de keuze tussen

32 in een brief d.d. 19-10-2002 deelt Warmond mee, dat dit proza niet afkomstig was uit Paspoont voor nicmandsland.

33 zie: Henk Struyker Boudier, Speurtocht naar en onbekende. Anna Blaman en haar 'Eenzaam Avontuur'. Amsterdam. $1978^{2}: 81$

34 dat geldt overigens niet alleen voor die periode. In een brief d.d. 19 oktober 2002 schrift Warmond: 'Mijn affiniteit met het existentialisme is, geloof ik, niet veel minder of anders geworden, denkelijk. doondat ik destijds het existentialsme ontdekte als een filosofie die ansloot aan de filosofie die ik al hád en dus meer illustratie dan ontdekking was.' 
'Lebensbejahung' en 'Lebensverneinung' centraal, respectievelijk gerepresenteerd door de figuren van Hans Erkelens en Esther Engelrijk. Net als in het werk van Blaman beseffen de personages dat het menselijk tekort niet op te heffen is. Alleen liefde en erotiek kunnen dat. Daarom kan Paspoort voor niemandsland in de Nederlandse literatuurgeschiedenis opgenomen worden als een wat laat voorbeeld van het esthetische existentialisme. 


\section{EXISTENTIALISME EN POËZIE}

\section{Een zoektocht naar verwijzingen}

In het essay 'De experimentele explosie in Nederland. Context en achtergronden' uit 1977 stelt Paul Rodenko dat Sartre, hoewel hij zelf geen gedichten schreef, veel invloed heeft gehad op de hedendaagse poëzie. ${ }^{1}$ Tegenstrijdig met deze opmerking over Sartres invloed is, dat handboeken en artikelen wat de naoorlogse Nederlandse poëzie betreft niet of nauwelijks verwijzen naar beïnvloeding door of affiniteit met het existentialisme. Het handboek Nederlandise Literatuur, een geschiedenis bijvoorbeeld meldt alleen dat Sartre de meest invloedrijke denker in de jaren na de bevrijding was en dat vooral het vertaalde werk van Camus populair was. De door Annie Cohen Solal geschreven biografie over Sartre wordt alleen maar genoemd als illustratie van het zogenaamde Adriaan van Dis-effect: de biografie werd vooral goed verkocht, omdat Adriaan van Dis de schrijfster indertijd interviewde voor de VPRO-televisie. ${ }^{2}$

Anbeek (1984) richt zich in zijn artikel over het existentialisme in de Nederlandse literatuur uitsluitend op de roman, zonder overigens te motiveren waarom hij zich beperkt tot dit genre. Dat geldt ook voor de reactie op dit artikel van Bert Vanheste (1992). Het handboek Tivee eeuwen literatuurgeschiedenis van Van Bork/Laan (1986) bevat slechts een samenvatting van Anbeeks visie en gaat dus ook niet in op het verband tussen existentialisme en poëzie. In een latere publicatie verwijst Anbeek zijdelings naar de mogelijke invloed van het existentialisme op de poëzie. Maar volgens hem geldt evenals voor de roman dat Sartre en de zijnen de Nederlandse literatuur niet hebben beïnvloed. Het ging veeleer om een gelijkwaardige internationale reactie op de oorlog, zowel in als buiten de literatuur, hoewel de Franse ideeën later wel tot een verscherpte formulering bij de Nederlandse dichters kunnen hebben geleid, aldus Anbeek, die deze interessante opmerking helaas niet verder adstrueert. ${ }^{3}$ In een voetnoot in dezelfde publicatie brengt hij het gedicht 'Bloemen leven licht-zinnig in hun bladen', het eenentwintigste sonnet van de Sonnetten van de kleine waanzin van Hans Andreus, in verband met het existentialisme. Het gedicht luidt als volgt:

Bloemen leven licht-zinnig in hun bladen.

Dieren lopen vanzelfsprekend; ze zwijgen

van wat ze zouden kunnen zijn; hun daden

gebeuren altijd nu; dieren zijn eigen.

1 in: Paul Rodenko, Verzamelde essays en kriticken. Deel 2. Amsterdam 1991: 375

2 M.A. Schenkeveld van der Dussen (hoofdred.). Nederlandse Literatum, een geschiedenis. Groningen 1993: 847

3 Ton Anbeek, Geschiedenis yar de Nederlandse literatuur 1885-1985. Amstendam 1990²:219 
5. Mensen doen alsof. Bestaan in ijskoude, denken, denken, denken dat zij bestaan.

Geen mens kent een mens. Men wil zich vasthouden.

Angst laat niet los. Men kijkt zijn spiegel aan.

En hangt zich op aan winterse systemen

10. of takken van geloof. Maar dood is dood.

Men neemt zich mee en is niet mee te nemen.

En ik ben eenzelfde. Maar leg mij bloot, omdat ik zien wil wie ik toch nog ben.

Ik moet toch iemand zijn die ik herken. ${ }^{4}$

Volgens Anbeek valt dit gedicht te lezen als een rechtstreekse vertaling van de filosofie van Sartre in poëzie. Hij noemt twee redenen, de rest van zijn argumentatie vervluchtigt in een 'etcetera":

Men vergelijke: de natuur die 'is' (être-en-soi) tegenover de mens die zich projecteert (être-pour-soi), de angst die deze kloof veroorzaakt, etcetera. ${ }^{5}$

Het is overigens begrijpelijk, dat een mogelijk verband tussen naoorlogse poëzie en existentialisme zo weinig aandacht krijgt, aangezien Vijftigers als Campert, Claus, Schierbeek en Kouwenaar, hoewel ze begin jaren vijftig al kennis hebben genomen van existentialistische literatuur ${ }^{6}$, aangeven vooral beïnvloed te zijn door de Engelse en Amerikaanse poëzie en door stromingen als het expressionisme, surrealisme en. dadaïsme. ${ }^{7}$ Fokkema's documentaire over de Vijftigers uit 1979 bevat dan ook nauwelijks verwijzingen naar het existentialisme. In een latere studie van hem over de geschiedenis van de Nederlandse poëzie sinds 1945 komt het ook nauwelijks aan bod. De enige gedichten die Fokkema min of meer expliciet in verband brengt met existentialistische literatuur staan in Sous-terrain (1950) van W.J. van der Molen, een in de Windroos-reeks uitgegeven bundel. De invloed van $L a$ nausée van Sartre weerspiegelt zich volgens Fokkema in thema's als leegte, angst, eenzaamheid, wanhoop en weerzin, die gezamenlijk de absurditeit van het bestaan oproepen. ${ }^{8}$ In een recensie in het cerste nummer van Braak (1950) noemt Remco Campert de dichter Van der Molen 'een loodzware humorloze Hollandse dominee'. Hij eindigt

4 in: Hans Andreus, De sonnetten van de kleine uaanzin. Haarlem 1999: 27

5 Ton Anbeck $1990^{2}: 292$

6. zie: H.J.A. Hofland en Tom Rooduijn, Duars door puinstof heen. Grondleggers van de naoorlogse litenttuur. Met documentaine over de Vijffigers op cd. z.p. 1997: 49-52

7 zie: R.I.K. Fokkema, Het komplot der Vijftigers. Een litenair-historische documentaire. Amsterdam 1979: $98 ; 157$

8. Redbad Fokkema, Aan de mond wun al die rivieren. Een geschiedenis uan de Nederlandse poezie sinds 1945. Amsterdam 1999: 94 
zijn bespreking met het volgende advies: 'Men moet de heer van der Molen eens flink in zijn zij kietelen."

Calis wijst op een ouder voorbeeld en wel het gedicht 'De laatste kans' van de Belg A.G. Christiaens, verschenen in de derde jaargang van Podium (1946-1947). Het gedicht bevat motieven die doen denken aan die van Sartres romans: walging en een gevoel van zinloosheid als belangrijke ingrediënten van het bestaan:

De sprake niet, maar eigen stem heb ik verloren ...

Mijn woorden zijn gestamel uit een vreemd domein.

Toen ik vereenzaamd liep voelde ik mij uitverkoren.

Nu moet ik me onder mensen mengen om te zijn.

5. In het begin was de angst: met kennis en de jaren

Besluipt mij slijmrig walg, waarbij mij 't harte keert

Om de evennaaste, in wie ' $k$ mij langer niet kan sparen,

Daar hij mij in zijn daad en zich in mij onteert.

En zo verzink ik onnaspeurbaar in het duister

10. Der wanhoop, stadium waarna de vrijheid wenkt.

Maar ze is geborgen in des doods fosforen luister,

En enkel hij ontsnapt die met zijn handen denkt ... ${ }^{10}$

In Van Ostaijen tot heden (Nijmegen/Antwerpen 2001), een studie van Geert Buelens over de Vlaamse poëzie, wordt een enkele keer naar het existentialisme verwezen. Het tijdschrift Tijd en Mens. Tijdschrift van de nieuwe generatic, in 1949 opgericht door onder anderen Louis Paul Boon, Jan Walravens en Hugo Claus, maakte naast allerlei andere ismen ook ruimte voor het existentialisme. Het manifest geeft onder meer als doelstelling aan, dat de redactie afscheid wil nemen van 'het huidig Vlaams geknutsel, dat men als neo-classicisme wil doen doorgaan'. In plaats daarvan willen de redactieleden:

onverpoosd het kruispunt opzoeken waar het moderne esthetische streven -zoals het zich openbaart in de abstracte kunsten, de simultaneistische, existentialistische, magisch-realistische en lettristische literatuur, de atonale muziek en de bouwkunst van Le Corbusier en Wright- het Vlaamse temperament ontmoeten kan. ${ }^{11}$

9 Remco Campert, 'Besprekingen.' In: Braak. Amsterdam 1950/1, p. 20

10 geciteerd in: Piet Calis, Speeltuin van de titaantjes. Schrijvers en tijdschriften tussen 1945 en 1948. Amsterdam 1993: 261

11 zie Geert Buelens, Van Ostaijen tot heden. Zijn invloed op de Vaamse poezie. Nijmegen/Antwerpen 2001: 586 
Verder noemt Buelens, zonder daar uitgebreid op in te gaan, nog Alfred Bontridder en Paul de Vree als voorbeelden van dichters die beïnvloed zijn door het existentialisme.

Hans van Stralen beperkt zich in zijn studie over het literaire existentialisme tot de roman en het toneel, omdat volgens hem in deze genres de existentialistische idecën het beste tot hun recht komen. Wel verwijst hij zijdelings naar het poëtische oeuvre van de vroege Schierbeek, Vasalis en Warmond. ${ }^{12}$ Het verdient mijns inziens aanbeveling om het werk van deze dichters vanuit een literair-existentialistisch perspectief nader te onderzoeken. Het is opmerkelijk, dat Van Stralen geen aandacht besteedt aan het werk van Paul Rodenko. In zijn artikel 'Poëzie, wrede machine' stelt Kusters dat Rodenko's debuut en dan vooral de afdeling 'Kamerpoëzie (1944-1947)'sterk onder invloed van het existentialisme stond, zoals dat met name in La nausée van Sartre een literaire vorm had gevonden. ${ }^{13}$ Woorden als 'traag, zwaar, log, langzaam, stom, moe, onbeweeglijk, lijzig, verveeld' en een grote nadruk op 'de dingen' spelen een grote rol in Rodenko's vroege poëzie, aldus Kusters. Ook Odile Heynders (1994) signaleert, dat de vroege gedichten van Rodenko uitdrukking geven aan een existentialistische levensbeschouwing, zoals blijkt uit thema's als het stollen van de tijd, stilte, zwaarte van handelingen en vertraging. ${ }^{14}$

In de gepopulariseerde versie van het existentialisme wordt altijd de nadruk gelegd op de somberheid en de absurditeit van het bestaan, zowel door dichters en romanschrijvers als door critici. In dit existentialisme gat het vooral om walging, vertraging, het Niets en de absurditeit. Dat is echter slechts één kant. In zijn lezing 'Lexistentialisme est un humanisme' (Parijs 1965) ${ }^{15}$ gat Sartre in op een aantal vooroordelen omtrent deze filosofische richting:

Zoals bekend wordt ons vooral verweten dat wij de nadruk leggen op de kwade kant van het menselijk leven. Onlangs vertelde men mij van een dame die, als ze van zenuwachtigheid een lelijk woord laat vallen, verontschuldigend zegt: 'Ik begin geloof ik existentialiste te worden.' Men associeert lelijkheid dus blijkbaar met existentialisme $\{\ldots\}$.

Ook wordt het existentialisme verweten berustend te zijn. Volgens Sartre is juist het tegendeel het geval, aangezien existentialisten het belang van het handelen sterk benadrukken. Hij stelt zelfs, dat geen leer optimistischer is:

12 Hans van Stralen. Beschreven keuzes. Een inleiding in het literaire existentialisme. Leuven-Apeldoorn 1996: 51

13 Wiel Kusters, 'Poëzic, wrede machine.' In: Ik graaf, jiij graff. Aantekeningen over poezic. Amsterdam 1995: 140-147

14 Odile Heynders, 'Paul Rodenko. Orensnijder tulpensnijder. Verzamelde gedichten.' In: Lexion van Litenuire Werken, Groningen 1994

15 Jean-Paul Sartre, Over het existentialisme. Utrecht/Aartselaar 1967:7 
want de lotsbestemming van de mens ligt in de mens zelf; het [=het existentialisme] kan ook niet worden gezien als een poging om de mens de moed tot handelen te ontnemen, want het vertelt de mens dat er geen hoop is buiten zijn handelen, en dat de daad het enige is dat de mens doet leven. Wij hebben op dit vlak dan ook te maken met een moraal van de actie en het engagement. (p.39)

Het is opmerkelijk, dat men voor deze optimistische kant van het existentialisme over het algemeen weinig oog had, althans in Nederland. Het verdient aanbeveling dat dit te zijner tijd eens nader onderzocht wordt.

Terug naar Rodenko. Volgens Heynders (1998) is hij een van de weinige Nederlandse dichters geweest die het existentialisme op een thematische manier in poëzie verwerkt hebben. Ze merkt terecht op, dat het opmerkelijk is dat het existentialisme nauwelijks als poëtisch gegeven erkend wordt. Zowel motieven als een daaraan gekoppeld idioom wijzen op existentialistische invloed in het werk van Rodenko, aldus Heynders. Bovendien wijst ze op verwantschap met Camus, met name vanwege motieven als de stilte en de dreiging van de zon, die in Camus' roman L'étranger een belangrijke rol spelen. ${ }^{16}$

Affiniteit met het existentialistische gedachtegoed is onder meer ook terug te vinden in het werk van Gerrit Kouwenaar ${ }^{17}$, Bert Schierbeek, Vasalis en Ellen Warmond. Een van de eersten die uitvoeriger over het werk van Warmond geschreven hebben is Jan van der Vegt in het essay 'Kijken in een gesloten spiegel', waarin hij stelt dat bepaalde gedichten van Warmond een soortgelijke ervaring beschrijven als de existentiefilosofie: angst en walging, voortkomend uit vervreemding. ${ }^{18}$ Een neerslag van deze opvatting is terug te vinden in zijn overzichtsartikel over Ellen Warmond in Kritisch Literafuur Lexicon. ${ }^{19}$

Het lijkt Van der Vegt verdedigbaar om sommige gedichten van Warmond tegen de achtergrond van de existentiefilosofie te plaatsen. Hij geeft daarvoor twee redenen: allereerst omdat veel literatuur uit de vroege vijftiger jaren affiniteit vertoont met het existentialistische levensgevoel zoals dat opgeroepen wordt in de romans van Sartre en Camus. Ten tweede omdat: Warmond al vanaf haar eerste bundel dat existentialistische levensgevoel vorm geeft en, in tegenstelling tot dichters als Andreus en de vroege Kouwenaar, bij wie dat levensgevoel ook terug te vinden is "existentie-filosofische begrippen een centrale plaats geeft in haar gedichten. Dat wil niet zeggen dat haar poëzie een filosofie in dichtvorm is, aldus Van der Vegt, maar zij gebruikt bepaalde filosofische begrippen als beelden of als thema's in haar verzen. Van der Vegt noemt onder andere de gestolde tijd, de leegte, de vervreemding en het onontkoombare tekort als een wezenlijk kenmerk van onze existentie. Hij noemt drie middelen warmee Warmond het 'inoperabel tekort' dragelijk probeert te maken: ironische distantie, liefde en de zoektocht naar stilte, die niet

16 Odile Heynders, Langzaam leren lezen. Paul Rodenke en de pokzie. Tilburg 1998: 89

17 ze Wiel Kusters, De killer. Over poizzie en poètica uan Gerrit Kouwenaar. Amsterdam 1986

18 Jan van der Vegt, 'Kijken in een gesloten spiegel.' in: Ons efdeel 1981, afl. 5, p. 655-664

19 Jan van der Vegt, 'Ellen Warmond.' in: Kritisch Litenutuur Lexicon. Gronungen 1984 
alleen een auditieve stilte veronderstelt, maar ook het stilzetten van of zelfs het ontstijgen aan de tijd. Hij vergeet echter nog één belangrijk middel, namelijk het schrijven van poëzie, zoals onder meer blijkt uit het openingsgedicht van Warmonds eerste bundel:

\section{EXCUUS}

Om het inoperabel tekort van gebaren die onvoltooid en gedachten die verzwegen blijven om alles wat nooit

5. kan worden prijsgegeven beroep ik me op het gedicht als machteloos tegenwicht. ${ }^{20}$

Het stiltethema komt in haar latere werk wat pregnanter naar voren, maar het was ook in haar vroegere werk al aanwezig, hoewel het daar nog met enige ironische distantie gepresenteerd wordt. In het openingsgedicht van Naar men zegt, haar tweede bundel, staat:

Naar men zegt is dit

het leven der wijzen:

niet meer bewegen stilstaan als een berg ${ }^{21}$

Volgens Van der Vegt blijkt uit Warmonds werk, dat zij dit oosterse stilte-ideaal onbereikbaar acht. Ik betwijfel dat. De dichter sluit dit niet helemaal uit, zoals mijns inziens blijkt uit het gedicht 'Voor wie uit is op inkeer $2 .{ }^{22} \mathrm{Zij}$ brengt weliswaar een. geografische restrictie aan ('hier ter plaatse'), de woorden. 'welhaast niet haalbaar' echter wijzen op een kleine mogelijkheid, al zal die niet eenvoudig te realiseren zijn:

Het oog op de Himalaya

of willekeurig welke bergtop laten rusten

en dan bedoel ik ook: r u s te n

zodat geen wimper meer fladdert

5. en geen gedachtestolsel knapt

20 in: Procfuin. Den. Haag 1953:5

21 in: Naar men zext. Den Haag 1955: 7

22 dat blijkt ook uit de gedichtencyclus 'Everest/Himalaya' uit de bundel Ondening (Amsterdam 1981). In hoofdstuk XI kom ik op deze gedichten terug. 
onder de vuile nagel der versterving

mooi moet dat zijn maar hier ter plaatse

welhaast niet haalbaar

door iedere gedachte aan niets

10. rijdt met knersende remmen een tram. ${ }^{23}$

Van der Vegt concludeert dat Warmond in de moderne Nederlandse poëzie een heel eigen plaats inneemt en dat haar werk veel meer aandacht verdient dan het tot nu toe gekregen heeft:

De boeiende wijze waarop zij filosofische begrippen in haar poëzie integreert zonder in abstracties te vervallen die juist voor poëzie dodelijk zijn, is nogal ongebruikelijk.

In een ongepubliceerde scriptie uit 1974, die blijkens de bibliografie bij zijn artikelen bij Van der Vegt niet bekend is, toonde H. Pelgrom al eerder overtuigend aan, dat diverse gedichten in het oeuvre van Warmond inhoudelijke overeenkomsten vertonen met existentialistische gedachten. ${ }^{24} \mathrm{Hij}$ concludeert dat de overeenkomsten zich niet beperken tot de filosofie van één vertegenwoordiger van het filosofische existentialisme, maar dat de overeenkomsten wel grotendeels gezocht moeten worden in de atheïstische variant, vertegenwoordigd door Sartre en Camus.

Hoewel Pelgrom interessante elementen aandraagt, kleven er enkele bezwaren aan zijn benadering. Hij gaat uit van het analogische model, waarin vooral gezocht wordt naar overeenkomsten tussen een bepaalde filosofie en een literaire tekst. Het bezwaar van dit model is, dat de verschillen tussen het literaire en het filosofische taalsysteem onderbelicht blijven. De nadruk ligt vooral op de inhoudelijke kant, waardoor er te weinig aandacht is voor de poëtische aspecten.

De inhoudelijke overeenkomsten betreffen vooral de periode 1953 tot 1969. Daarna is er minder materiaal te vinden, aldus Pelgrom, omdat de volgende bundels meer gekenmerkt worden door gerichtheid op de maatschappij. Waarschijnlijk verwijst Pelgrom hiermee naar een maatschappelijk engagement, dat met name in de bundels De groeten aan andersdenkenden (1970) en Saluutschot met knaldemper (1972) naar voren komt. Aangezien maatschappelijk engagement in de boeken van Sartre, De Beauvoir en Camus een saillante rol speelt, vraag ik me af of het ten tonele verschijnen van dit element in het werk van Warmond inderdaad een breuk met het existentialisme aangeeft. In hoofdstuk VIII meer hierover.

Pelgrom heeft het werk van Warmond uit de periode 1953-1972 onderzocht aan de hand van een aantal trefwoorden die situaties aangeven waarin de mens zijn exis-

23 uit: 'Voor wie uit is op inkeer 2'. In: Uitzicht op inzidht. Amsterdam 1974: 40

24 H. Pelgrom, Ellen Warmond' en het existentialisme. z.p. 1974. Met dank aan Ellen Warmond, van wie ik haar exemplaar van de scriptie moche kopięren. Een kopie van Pelgroms scriptic kan bij de auteur van dit bock opgevraagd worden. 
tentie het sterkst beleeft. Ieder lemma wordt besproken aan de hand van vijf duidelijke voorbeeldgedichten. Deze trefwoorden, die voor een groot deel overeenkomen met de criteria die Van Stralen 1996 hanteert, zijn: de ander, dood en tijdelijkheid, verveling en walging, angst en absurditeit, wanhoop, 'en toch'. Het laatste aspect geeft aan, dat de levensdrang zich niet laat wegdrukken door de zin-loosheid of absurditeit van het leven. Dit 'en toch' valt enigszins samen met het engagementsconcept van Van Stralen, waarin het engagement drie vormen aan kan nemen: cynische berusting, positieve aanvaarding of daadwerkelijke verandering. Elementen die bij Pelgrom niet of nauwelijks aan de orde komen zijn: gesloten ruimtes en de geseculariseerde invulling van christelijke begrippen. Uiteraard ook niet de registerwisselingen van literair naar filosofisch taalgebruik en het gegeven dat personages meer typen dan round characters zijn, aangezien dit vooral van toepassing is op het genre van roman en drama, hoewel er in de poëzie van Warmond een enkele keer een sjabloonachtige figuur voorkomt als vertegenwoordiger van een bepaalde levensvisie. Een voorbeeld daarvan is het in staccato geschreven gedicht met de titel 'Leider':

\section{LEIDER}

Hij is.

Hij bewoont een kuras. Hij is. Hij beveelt.

Gooit kastanjes in andermans vuur.

Lacht in zijn modderen vuist.

5. Beveelt.

Hij is een stuipende pruik

van gewichtigheid.

Een buik.

Beveelt:

10. aanstaande lijken in het gelid.

$\mathrm{Hij}$ is.

Oogstende hereboer

op andermans dodenakker.

Beveelt.

15. Hand die zich sluit

rond andermans strot. 
Hij is.

Blijvend. 25

\section{Uitgangspunten}

In zijn studie over het literaire existentialisme laat Van Stralen de poëzie volledig buiten beschouwing. De nadruk ligt volgens hem vooral op het proza en het drama, vanwege de grote interesse voor de dialoog, die een geschikt middel is om conflictsituaties duidelijk te maken en om ideeën over te dragen. Bovendien kan de schrijver in het theater zijn ideeën direct in contact met het publiek brengen en ook eenvoudig actualiseren, aldus Van Stralen. Hier valt iets voor te zeggen. Aan de andere kant zijn er genoeg existentialistische elementen die ook in poëzie tot hun recht komen. Volgens Van Stralen valt het literaire existentialisme nagenoeg uitsluitend te begrijpen vanuit de beginselen van de existentiële fenomenologie, niet vanuit strikt literaire procédés. Op basis van deze uitspraak is er geen enkele reden de poëzie uit te sluiten. De belangrijkste door hem genoemde thema's -de grenssituatie, de ander en het engagement- worden ook in de poëzie aangetroffen, al zijn ze misschien op een andere manier literair vormgegeven dan in een roman het geval is.

In dit deel onderzoek ik op welke wijze de affiniteit van Warmond met existentialistische ideeën ook tot uiting komt in haar poëzie. Net als in het eerste deel van mijn studie ga ik uit van het hermeneutische model, waarin de relaties tussen literatuur en filosofie betekenisvol worden gemaakt zonder de autonomie van het literaire werk uit het oog te verliezen. Als interpretatiekader dient de existentiële fenomenologie, waarbij de nadruk zal liggen op pre-reflexiviteit en lichamelijkheid. Uiteraard zal ik indien zinvol ook aandacht schenken aan de formele/literaire aspecten. Bovendien wil ik onderzoeken in hoeverre zowel het conflictmodel van Sartre als het ambiguiteitsmodel van Merleau-Ponty als interpretatiekader in te zetten zijn. In hoofdstuk VIII zal ik nagaan of het toenemende maatschappelijke engagement in de bundels De groeten aan andersdenkenden (1970) en Saluutschot met knaldemper (1972) inderdaad een breuk met de existentialistische thematiek in het werk van Warmond aangeeft, zoals Pelgrom in zijn studie stelt. Daarbij zal ik ook ingaan op Sartres visie op poëzie, die minder eenduidig blijkt te zijn dan algemeen wordt aangenomen.

\section{Het spiegelmotief}

In het poëtische oeuvre van Warmond speelt het spiegelmotief misschien geen prominente maar wel een belangrijke rol, het komt in vrijwel al haar dichtbundels voor. Alleen Vluchtstroken van de taal (1988) is spiegelloos, maar in Kaalslag (1999) verschijnt het motief weer. Verder is het terug te vinden in het verhaal 'De weg naar

25 in: De groeten aan andendenkenden. Amsterdam 1970:40 
de roem' in de verhalenbundel Eeuwig duurt het langst. ${ }^{26}$ In de roman Paspoort voor niemandsland speelt het spiegelmotief een belangrijke rol, met name op momenten dat de hoofdpersoon zich in een grenssituatie bevindt en geconfronteerd wordt met: voor het existentialisme kenmerkende gevoelens als angst, vervreemding en walging.

Het kijken in de spiegel is in Warmonds werk over het algemeen niet neutraal maar confronterend. De zelfreflectie gaat vaak gepaard met angst, verwarring, teleurstelling, zelfspot, weerzin en zelfs nausée. Er kan sprake zijn van een dubbele identiteit: het lyrisch subject herkent zichzelf in de spiegel, maar zijn spiegelbeeld ervaart hij tegelijkertijd als dat van iemand anders. De spiegel vergroot de actieradius van het oog, waardoor we onszelf kunnen zien zoals een ander ons ziet. Soms kan dit uitlopen op een vervreemdende tweedeling tussen zelfbeeld en spiegelbeeld, zoals blijkt uit het gedicht 'Vereenvoudigde religie'27, dat straks uitvoerig behandeld. wordt. Deze tweedeling heeft een enkele keer een temporele dimensie: het gedicht is dan als het ware een tweeluik, waarop heden en verleden zichtbaar zijn. Ze vormen elkaars tegenbeeld. Een voorbeeld daarvan is 'Chanson prèsque triste' ${ }^{28}$ :

Hij beloofde zijn toekomst een spierdier

een technicolorpotentie

een bicepsbeeld

maar ontmoette bij daglicht zijn waarheid

5. naakt in de straten:

een wirwartol verdwaald

in mierennesten haastige verwarring

voor honderden ogen een 1-oog.

In dit gedicht is de toekomstdroom vol conventionele mannelijkheidsattributen geen werkelijkheid geworden. Het is opmerkelijk, dat veell gedichten van. Warmond een mannelijk lyrisch subject hebben. In hoofdstuk VII zal ik: hier nader op ingaan. Soms zien we een gefragmenteerd zelfbeeld in de spiegel, bijvoorbeeld in het gedicht 'Plastische chirurgie'29:

met een volleerd

gebaar wordt een blik als een kreet

of een mond als een angstkramp.

gecorrigeerd

26. Amsterdam 1961:125

27 in: Naar men zegt. Den Haag 1955: 33

28 in: Naar men zcgt. Den Haag 1955: 31

29. in: Proeftuin. Den Haag 1953: 18 
alleen komt soms uit het moeras

van eenzaamheid achter ogen

nog een witte wanhopige hand

voor de laatste maal boven.

De lezer krijgt niet de volledige persoon gepresenteerd: alleen ogen, mond en hand worden benadrukt, waardoor het lichaam gereduceerd lijkt te zijn tot deze onderdelen. Uit een aantal gedichten wordt duidelijk, dat illusies in de loop der tijd getransfor-meerd zijn in desillusies; de bewustwording daarvan komt tot stand via de spiegel. Een enkele keer gebruikt Warmond de metafoor van de gebarsten spiegel om gedesillusioneerdheid en verloren kansen op te roepen. Een voorbeeld daarvan is 'De beste compositie is de stilte ${ }^{30}$, geschreven naar aanleiding van de dood van Jan Arends:

zoveel gelijksoortig gebarsten spiegels

waarin zoveel gelijke gemiste kansen

elkander kaatsend beconcurreren.

Het spiegelmotief heeft niet overal een connotatie van zwaarte en zwartheid. In 'Op R.C.' ${ }^{31}$ is er sprake van een zekere zelfspot. Het lyrisch ik, dat we in dit geval mogen vereenzelvigen met Warmond, kijkt naar een foto van de even oude Remco Campert. Ze kreeg samen met hem in 1953 de Reina Prinsen Geerligsprijs voor poëzie. Niet alleen leeftijd en prijs, maar ook dat intrigerende teken des tijds de onderkin blijken zij gemeenschappelijk te hebben, zo registreert het lyrisch ik na een snelle blik in de spiegel, die hier een temporele dimensie heeft. In de spiegel ziet zij namelijk hoe de tijd zich aftekent op haar gezicht; het is alsof het verouderingsproces zich in de spiegel voltrekt. Zo wordt het gedicht niet alleen een portret van Remco Campert, maar ook van Ellen Warmond. Een dubbelportret dus:

\section{Op R.C.}

Foto van de jonge dichter

(jong toen ik jong was we zijn

op een paar maanden na

even oud)

5. een foto met (onmiskenbaar)

een onderkin

30 in: Uitzicht op inzicht. Amsterdam 1974: 24

31 in: Testbeeld voor koud klimaat. Amsterdam 1966: 33 
eens deelden we samen een prijs

tot verontwaardiging van wederzijdse vrienden

maar kan men helpen dat men prijzen krijgt?

10. soms wel meestal

en ook in dit geval

niet

een onderkin slordig

een beetje

15. opzettelijk niets-aan-te-doen-kalkoens

ik kijk snel opzij in een spiegel:

een onderkin.

In de meeste gedichten waarin het spiegelmotief een rol speelt, is de spiegel een plaats van confrontatie. Het lyrisch subject is op zichzelf gefocust door middel van een vernauwde en benauwende blik. Er zijn echter een paar gedichten waarin iets anders aan de hand is: aan de ene kant een al dan niet gerealiseerd verlangen naar verzoening met het eigen spiegelbeeld, bijvoorbeeld in 'Bijna alles / Bijna niets ${ }^{-32}$. Aan de andere kant verzen warin het lyrisch subject het op zichzelf teruggeworpen zijn wenst te doorbreken door -al dan niet succesvol-contact te zoeken met de ander. Een voorbeeld daarvan is het gedicht 'Vereenvoudigde religie', dat in de volgende paragraaf aan een nader onderzoek wordt onderworpen.

Als vrouwelijke personages zich bezighouden met hun identiteit of zich door een crisis teruggeworpen voelen op zichzelf, richten ze zich opmerkelijk vaker dan mannelijke personages op contemplatie van het eigen spiegelbeeld, aldus Jenijoy La Belle in Herself Beheld, een studie over het spiegelmotief in de -vooral Engelstaligeliteratuur. ${ }^{33}$ Zowel het uiterlijk als het innerlijk kunnen onderwerp zijn van contemplatie. Het vrouwelijke personage bekijkt in de spiegel niet alleen hoe ze er uitziet, maar ook hoe 'de wereld' haar ziet. Om dat te onderzoeken, dient ze zichzelf in de spiegel als een object te observeren. De spiegel wordt gebruikt om een sociaal acceptabele persoonlijkheid te creëren. Het vrouwelijke personage vergelijkt haar spiegelbeeld met de heersende sociale normen. Het resultaat daarvan kan bevestigend, ontkennend of zelfs revolterend zijn.

Kenmerkend voor de spiegelervaring is het gevoel van het dubbele of complexe 'zelf' , dat zowel subject als object is. In de spiegel wordt de kijker zich al kijkende bewust van de tweespalt tussen het gereflecteerde beeld en de innerlijke gesteldheid. Soms kan dit een ernstige psychologische confrontatie opleveren. Een gebroken spiegel bijvoorbeeld kan een gebroken 'zelf' suggereren.

De spiegel wordt volgens La Belle zowel gebruikt om zichzelf te analyseren als om een bepaald zelfbeeld te creëren. La Belle gelooft niet in een statisch 'zelf'. Ze ziet

32 in: De haid als nalkvlak. Amsterdam 1964:58

33 Jenijoy La Belle, Herself Beheld. The Litenature of the Looking Glass. Ithaka/London 19892:9 
het 'zelf' als een activiteit, een voortdurend proces waarin iemand zichzelf probeert te definiëren ten opzichte van anderen én in relatie tot anderen. Naar zichzelf in de spiegel kijken is met name voor vrouwelijke personages onderzoeken wie en wat ze werkelijk zijn. Het is een voortdurend proces van zelfverwerkelijking, aldus La Belle. Met deze stellingname levert ze kritiek op de visie van de Franse psychoanalyticus Jacques Lacan (1901-1981). Volgens Lacan is de spiegelfase een eenmalige gebeurtenis. ${ }^{34}$ Zichzelf herkennen in de spiegel wordt beschouwd als een teken van zelfbewustzijn. Mens, gorilla, chimpansee en, naar onlangs duidelijk is geworden, de olifant blijken hiertoe in staat te zijn. Lacan heeft zich intensief beziggehouden met het spiegelstadium in de ontwikkeling van het jonge kind. Hierbij zijn twee stadia van belang: de imaginaire orde, die verbonden is met het beeld, en de symbolische orde, die verbonden is met het woord. Het is essentieel dat een mens de overgang van het imaginaire naar het symbolische stadium doormaakt. Kenmerkend voor de imaginaire orde is het spiegelstadium. In deze fase wordt de basis gelegd voor het Ik. In de spiegel ziet het kind voor het eerst zichzelf, maar dat niet alleen: het ziet zichzelf in zijn geheel, als totaalbeeld. Dit spiegelbeeld is de basis voor het ontwikkelen van een identiteit, het kind legt een verband tussen zichzelf en het spiegelbeeld, het gat zich met dit beeld identificeren.

Deze identificatie impliceert vervreemding, omdat het tegelijkertijd een identificatie is met iets, wat het kind zelf niet is. In de spiegel ontmoet het kind namelijk zichzelf én de ander, niet de ander-die-anders-is, maar de andere-gelijke ofwel het eigen spiegelbeeld. Er is sprake van een twee-eenheid. Lacan noemt deze identificatie imaginair, omdat het een identificatie met een beeld is, in dit geval het spiegelbeeld. Deze identificatie is ook imaginair, omdat het kind zich identificeert met een totaalvoorstelling, terwijl het zichzelf nog niet als totaliteit kan beleven.

De symbolische orde bestaat uit een geheel van symbölen en wel in eerste instantie de taal. De wording van het subject valt samen met de toegang tot de taal, aldus Lacan. Het kind krijgt een naam en identificeert zich met deze naam. Deze identificatie verloopt niet meer via het beeld, maar via het woord. Met de taal kan het kind zichzelf en de ander onderscheiden, het kan een onderscheid aanbrengen tussen grammaticaal en sprekend subject. Het systeem van het persoonlijk voornaamwoord maakt het immers mogelijk afwisselend verschillende posities in te nemen: $\mathrm{ik}-\mathrm{jij}$ - hij/zij. De wording tot subject wordt echter betaald met een verlies: de narcistische twee-eenheid uit de imaginaire fase wordt definitief verbroken. Het verliezen van de twee-eenheid genereert automatisch het verlangen, want zonder een gemis of tekort valt er niets te verlangen. Het verlangen wil dit zijnstekort (le manque à être) opheffen, maar dat kan alleen als het subject zichzelf-als subjectopheft. Dit is echter fundamenteel onmogelijk. Dat is de prijs die de mens moet betalen voor zijn wording tot subject. Hij is definitief verdreven uit het imaginaire paradijs, aldus Lacan.

34 zie A. Mooij, Taal en verlangen. Lacans theoric van de psychoanalyse. Meppel 1997 77 -87 
Volgens Merleau-Ponty is het echter wel mogelijk het directe en primitieve contact met de wereld terug te krijgen. Deze pre-reflexieve en pre-conceptuele basiservaring is in zijn visie primair. Het is het reflexieve denken dat ons onderscheid laat ervaren tussen subject en object. In hoeverre deze visie ook doorklinkt in de poëzie van Warmond zal later nog blijken.

In tegenstelling tot Lacan gaat La Belle ervan uit, dat de spiegelfase geen eenmalige gebeurtenis is. Volgens haar is er eerder sprake van een herhaaldelijk voorkomend proces van zelfverwerkelijking. De belangrijkste confrontatie voor de vrouw vindt plaats in de puberteit, niet in de kindertijd, aldus La Belle. De vreemdheid of het anders-zijn van het spiegelbeeld helpt de adolescent in haar psychische ontwikkeling. Zij ervaart haar nieuwe lichaam in eerste instantie als vreemd. Pas later raakt ze zodanig vertrouwd met haar spiegelbeeld, dat ze in plaats van 'dat is zij' kan zeggen 'hier ben ik'. Uit het onderzoek van La Belle blijkt, dat veel verhaalfiguren een opeenvolging van belangrijke confrontaties met de spiegel ondergaan tijdens verschillende fases van hun ontwikkeling, van kindertijd tot adoslescentie tot ouderdom.

In hoeverre gaat de analyse van La Belle ook op voor het werk van Warmond? La Belle wees er in haar studie van het spiegelmotief op dat met name twee aspecten belangrijk zijn: de contemplatie van het uiterlijk en de contemplatie van de innerlijke gesteldheid. Gefocust zijn op het uiterlijk speelt in Warmonds poëzie vrijwel geen rol, behalve in 'Op R.C.', waarin ze op speels-ironische wijze haar onderkin tot onderwerp van het gedicht maakt. Blijkbaar is dit aspect voor haar niet relevant, althans niet als poëtisch onderwerp. De spiegel functioneert in haar werk ook niet als een middel om een sociaal acceptabele persoonlijkheid te creëren. De nadruk ligt duidelijk op de innerlijke confrontatie. Het spiegelmotief staat voor een innerlijk proces waarin het lyrisch subject via het spiegelbeeld onderzoekt wie of wat hij werkelijk is. Binnen dit kader weet Warmond het spiegelmotief op een veelzijdige manier te presenteren. Motieven als angst, weerzin, vervreemding, walging en verlangen naar de ander wijzen op een zekere affiniteit met de existentialistische thematiek.

Dat de confrontatie met de spiegel niet gebonden is aan een bepaalde leeftijdsfase, zoals La Belle stelt, blijkt uit het feit, dat er in het werk van Warmond geen bepaalde ontwikkeling in de tijd van dit motief is aan te wijzen. Het is bijvoorbeeld niet zo, dat alleen de eerste bundels een confronterende ontmoeting in de spiegel bevatten en de laatste bundels vooral over verzoening met het spiegelbeeld gaan. De verschillende facetten van het spiegelmotief kunnen verspreid door allerlei bundels en naast elkaar voorkomen.

Om een aaneenschakeling van analyses te voorkomen heb ik ervoor gekozen om één spiegelgedicht uitgebreid te analyseren en wel het gedicht 'Vereenvoudigde religie', omdat daarin verschillende facetten van het gecompliceerde Warmondiaanse spiegelmotief samenkomen. Bovendien is dit gedicht representatief voor een. aantal spiegelgedichten waarin enkele motieven voorkomen die existentialistisch 
andoen: walging, vervreemding, verlangen naar contact en het lichaam ervaren als Körper, dat wil zeggen als een object. Maar nu eerst het gedicht:

\section{VEREENVOUDIGDE RELIGIE}

Hij vergiste zich telkens opnieuw

op dezelfde hoopvolle wijze

maar toen de god met de glimlach

verhongerd was

5. bouwde hij in de spiegel

een antigod en leerde

zichzelf te haten zoals men

een voorwerp haat

zo won hij dagelijks afstand

10. tot hij ten slotte zijn lichaam

onteigend had en het 's avonds

tussen zijn lakens schoof

als een zakelijk toegevouwen

brief in een enveloppe.

In dit gedicht, dat verhalend aandoet, wijkt Warmond af van de conventionele lyrische situatie door gebruik te maken van een impliciet externe vertelinstantie. Het lyrisch subject ('hij') is niet de woordvoerder van het gedicht. Tussen ons als lezers en het lyrisch subject zit een. registrerende instantie via wie we het een en ander te horen krijgen. Deze poëtische taalsituatie creëert een afstand, die binnen de depersonalisatiethematiek van dit gedicht functioneel is. Of misleidt de woordvoerder ons en is hij toch dezelfde als het lyrisch subject? Maar wat heeft hij daarmee dan op het oog? Zichzelf aanduiden in de derde persoon enkelvoud getuigt van afstandelijkheid, of op zijn minst van afstand nemen. Deze vorm maakt daardoor het vervreemdingsproces zichtbaarder.

Het gedicht bestaat uit twee samengestelde volzinnen, die samenvallen met de beide strofen. In beide volzinnen komt nevenschikking voor: r.1-8 valt uiteen in 'Hij vergiste ... hoopvolle wijze' en 'maar toen ...voorwerp haat'; r.9-14 valt uiteen in 'zo won ... onteigend had' en 'het 's avonds ... een enveloppe'.

De eerste nevenschikking is tegenstellend van aard en accentueert het overgaan van hoopvolle verwachting in opstandigheid, terwijl de nevenschikking in de tweede strofe een temporele geleding aangeeft: de genoemde situaties volgen elkaar op in de tijd. Deze grammaticale constructie geeft op een constaterende manier de eindfase van het depersonalisatieproces aan. 
Het gedicht heeft geen rijmschema, maar kent wel alliteratie en assonantie. Waar nodig ga ik daar verder op in. Het gedicht telt veertien regels, verdeeld over twee strofen: een octaaf en een sextet. Dit lijkt een sonnetachtige structuur, te meer daar tussen octaaf en sextet een inhoudelijke chute aanwijsbaar is. Het octaaf richt de aandacht op het voorafgegane proces, terwijl het sextet aangeeft waarin dat proces uiteindelijk culmineert: depersonalisatie. Een formele chute wordt gevormd door de presensvorm in r. 8. Het gedicht bevat overwegend imperfectumvormen ('vergiste zich', 'bouwde', 'leerde', 'won', 'schoof'), die als het ware een registrerend, objectiverend verslag oproepen, Iedere strofe bevat één plusquamperfectum: 'verhongerd was' (r. 4) en 'onteigend had' (r. 11). Deze vorm geeft aan dat de daarin genoemde processen definitief verleden tijd zijn. Het hele gedicht ademt daardoor een sfeer van temporele afstand. Dan verschijnt er in r. 8 ineens een presensvorm: 'zoals men een voorwerp haat'. Door het onbepaald voornaamwoord 'men' wordt de handeling ('haten') centraal gesteld. Het gaat niet om de 'handelende' persoon, die blijft op de achtergrond. Het enjambement in r. 7 richt weliswaar de aandacht op 'men', maar dit 'men' is een onpersoonlijke massa. De presensvorm kan een algemene warheid aangeven die onafhankelijk is van de tijd, omdat ze geldt voor heden, verleden en toekomst, zoals in de uitdrukking 'rust roest'. In dit gedicht accentueert het presens de actualiteit van de haat: die is niet gesitueerd in een afgesloten verleden. De handeling staat centraal, degene die haat verdwijnt als het ware naar de achtergrond.

De eerste regels werken verrassend door het enjambement. Een gebruikelijker zinsbouw zou zijn: 'hij hoopte telkens dat hij zich opnieuw vergiste', waarin 'hopen' meer naar voren komt dan 'zich vergissen'. In Warmonds versie is dat echter andersom: het licht valt nu -mede door het versterkende en repeterende effect van de woorden 'telkens' en 'opnieuw'- op de vergissing. Dat repeterende effect heeft ook betrekking op de hoop, zoals blijkt uit het woord 'dezelfde' (r. 2). 'Hoopvolle verwachting' en 'zich vergissen' gaan blijkbaar gelijk op. Dit proces is echter eindig, zoals blijkt uit de rest van de eerste strofe.

Het enjambement in r. 3-4 is ook verrassend: het verscherpt de tegenstelling tussen de lieflijke metafoor van de derde regel ('de god met de glimlach') en het harde begin van de volgende regel ('verhongerd'). Het antithetische tweede deel van deze strofe roept allerlei vragen op. Wie is die 'god met de glimlach'? Wat drukt die glimlach uit: aanmoediging, vertedering, superioriteit? Waardoor of door wie is deze god dan verhongerd? Door het lyrisch subject, door zijn vergissingen?

Dit zijn open plekken in de tekst. Misschien zijn bovenstaande vragen overbodig, als we in r. 3-4 ('maar toen de god met de glimlach verhongerd was') een allusie zien doorschemeren en wel op de uitdrukking: het lachen is hem vergaan.

Het enjambement in r. 5 richt de andacht van de lezer op de spiegel: dáár gebeurt het. Het lyrisch subject bouwt in de spiegel een antigod: dat kan alleen als hij in de spiegel zichzelf ziet. De 'antigod' moet dus wel een beeld van hemzelf zijn. Hieruit 
kunnen we concluderen dat dit ook geldt voor 'de god met de glimlach', die geassocieerd wordt met hoopvol optimisme, terwijl 'de antigod'verbonden is met haat. Er is iets vreemds aan de hand: de spiegel suggereert ruimtelijkheid, maar dat is bedriegelijk, want hij is in feite eendimensionaal. Toch wordt de spiegel in r. 5 gepresenteerd als een ruimte, als een werkplaats waarin gebouwd wordt. Dit beeld roept net als andere elementen in dit gedicht afstand op: het lijkt alsof de transfor-matie niet in zichzelf, maar buiten zichzelf gerealiseerd wordt.

Het woord 'bouwde' valt op, omdat hierin het assonantiepatroon van de eerste strofe doorbroken wordt, waarin i/ie-, o/oo- en a/aa-klanken overheersen. Bouwen duidt op construeren, op doordachte wijze in elkaar zetten. Het woord geeft aan, dat de 'antigod' een eigen constructie van het lyrisch subject is. Het in de spiegel creëren van een identiteit is een bekend thema in de literatuur. Een voorbeeld daarvan is 'Drei Gedichte aus dem Umkreis: Spiegelungen II' van Rilke ${ }^{35}$ :

Immer wieder aus dem Spiegelglase

holst du dich dir neu hinzu;

ordnest in dir, wie in einer Vase,

deine Bilder. Nennst es du,

dieses Aufblühn deiner Spiegelungen

Het woord 'bouwen' associeer ik niet alleen met construeren; het roept bij mij ook andere uitdrukkingen op: luchtkastelen bouwen en hypothesen bouwen. Als deze uitdrukkingen er inderdaad in doorklinken, wordt de aandacht gevestigd op het hypothetische en imaginaire karakter van het bouwwerk 'de antigod'.

De 'god met de glimlach' wordt opgevolgd door een 'antigod'. Het woord 'antigod' komt niet voor in de door mij geraadpleegde woordenboeken. Waarschijnlijk wordt met dit neologisme de te haten tegenhanger bedoeld, het tegenbeeld van 'de god met de glimlach'. Ook hier zou wel eens sprake kunnen zijn vạn een allusie en wel op de antichrist. Dit is de door Satan gezonden vijand die de plaats wil innemen van Christus, maar uiteindelijk verslagen zal worden. De antichrist vertegenwoordigt haat, (tijdelijke) triomf en definitieve ondergang. In de metafoor 'antigod' zouden enkele van deze connotaties wel eens mee kunnen klinken: een overwinning, maar een tijdelijke!

Misschien klinkt in r. 5-6 ook de uitdrukking 'bouwen op god' door. Het lyrisch subject vindt namelijk houvast in zijn eigen constructie. Opvallend is hier ook een verandering van metrum. Het metrum bestaat voornamelijk uit anapesten, die het gedicht een zekere vloeiendheid geven, maar r. 5-6 is meer jambisch van structuur, klinkt meer syncopisch, staccato-achtig, wat een verbeten effect veroorzaakt. Tot in het metrum toe weet Warmond het proces zichtbaar en voelbaar te maken.

Het enjambement in r. 6-7 houdt de spanning erin: wat leerde hij? De zin 'leerde zichzelf te haten' heeft een ambigue structuur. Is het: 'leerde zichzelf / te haten' of is

35 R. M. Rilke, Werke Band II-1 Gedichte und Ubertragungen. Frankfurt am Main 1984 ${ }^{3}: 181$ 
het 'leerde / zichzelf te haten'? Met andere woorden: hoort het reflexivum bij 'leren' of bij 'haten'? In het eerste geval wordt benadrukt dat het initiatief om te gaan haten van het lyrisch subject zélf uitgaat. Bovendien is het haten in deze interpretatie niet gericht op een specifiek persoon; de haat wordt extra belicht, terwijl de persoon die haat of gehaat wordt naar de achtergrond verdwijnt. In het tweede geval is het haten wel gericht, namelijk op zichzelf. Ik opteer voor een derde mogelijkheid, aangenomen dat er twee zinsdelen zijn samengevallen: 'leerde zichzelf / zichzelf te haten'. Deze linguistische verdichting of gecomprimeerdheid heeft een versterkend effect, aangezien het accent daardoor op beide aspecten valt: op de haat én op zichzelf.

Het werkwoord 'leren' is polyinterpretabel: het betekent onder andere 'onderwijzen', 'een kundigheid verwerven' en 'zich de gewoonte van iets eigen maken'. Samen geven deze betekenissen een proces aan: door zichzelf te onderwijzen verwerft hij de kundigheid zichzelf te haten; vervolgens wordt dit haten een gewoonte die hij zich eigen heeft gemaakt.

De vergelijking in r. 7-8 verrast me, ze ligt niet voor de hand. Deze regels roepen bij mij een tegengestelde uitdrukking op: "heb uw naaste lief gelijk uzelve". Deze uitdrukking lijkt meer bij de 'god van de glimlach' te passen, terwijl de regel 'zoals men een voorwerp haat' meer aansluit bij de 'antigod'. In plaats van woorden die een zekere nabijheid aanduiden ('liefhebben', 'uw naaste' en 'uzelve') staan er nu woorden die afstandelijkheid en iets onpersoonlijks aangeven ('haten', 'men' en 'een voorwerp'). Maar waarom juist 'zoals men een voorwerp haat' en niet zoals men een mens haat? Of is dat laatste te gepassioneerd voor iemand die al zo'n afstand tot zichzelf ervaart? De vergelijking accentueert mijns inziens de toenemende distantie van het lyrisch subject. Eerst was hij voorwerp van zelfhaat, nu voelt hij zichzelf inmiddels -al dan niet gedeeltelijk- een voorwerp. Het lichaam wordt niet ervaren als Leib maar als Körper ofwel als een ding. Ik vraag me af of je hier nog kunt spreken van depersonalisatie. Depersonalisatie betekent dat iemand het gevoe! heeft zijn eigen persoonlijkheid te verliezen, waarbij hij zichzelf als een vreemde ervaart. In dit gedicht gaat het lyrisch subject echter een stapje verder: hij ervaart zichzeif niet zozeer als een vreemde als wel als een voorwerp. Hier is eerder sprake van verdingelijking dan van depersonalisatie.

De tweede strofe begint met een samenvattende zin: 'zo won hij dagelijks afstand', waarbij 'zo' verwijst naar het proces dat in de eerste strofe opgeroepen wordt. Het bouwen van een antigod en de zelfhaat resulteren in het verkrijgen van afstand, dat is zijn 'winst', 'Winnen' interpreteren als 'een prijs winnen', waarbij 'afstand' de prijs is, lijkt me hier niet zo zinvol. De afstand is eerder de prijs die hij moet betalen voor zijn manier van doen. Met 'afstand' wordt hier mijns inziens verwijdering en. afstandelijkheid bedoeld, er is een toenemende distantie tussen het lyrisch subject en zijn lichaam. Maar het kan ook een vooruitverwijzing zijn naar 'onteigening' in de volgende regels: het lyrisch subject verkrijgt van dag tot dag meer afstand met als resultante de onteigening van zijn lichaam. 
We zijn nu aangekomen bij het sluitstuk van het depersonalisatieproces: het lyrisch subject heeft ten slotte zijn lichaam 'onteigend'. Het enjambement in r. 10 accentueert het metonymische 'lichaam'. Het werkt ook hier verrassend, want het woord 'lichaam' verwacht je niet in combinatie met 'onteigend. 'Onteigenen' betekent: iemand zijn eigendom ontnemen waardoor het overgaat in andermans handen. Het prefix 'ont' geeft een scheiding aan, zoals in 'ontvluchten'. In dit gedicht krijgt het werkwoord een Warmondiaanse invulling: 'onteigenen" is hier letterlijk: ont-eigen-en, dat wil zeggen ontnemen aan zichzelf in plaats van aan een ander. Het lichaam wordt niet meer ervaren als iets van zichzelf, maar dat heeft het lyrisch subject zelf bewerkstelligd. Hij heeft zijn lichaam aan zichzelf ontvreemd.

Het gedicht bevat twee woordvelden: een woordveld dat het procesmatige aangeeft: 'bouwde, leerde, won, dagelijks, ten slotte' en een woordveld waarin de notie afstand op de voorgrond treedt: "haten, voorwerp, afstand, onteigend, schoof, zakelijk, toegevouwen, enveloppe'. Deze twee woordvelden schuiven vanaf r. 6 in elkaar. Het zijn twee kanten van het depersonalisatieproces: het ene woordveld heeft met de geleidelijkheid ervan te maken en het andere woordveld met het finale resultaat. Uit r. 11-12 blijkt hoe groot de afstand van het lyrisch subject tot zijn lichaam geworden is. Het, schuiven van een voorwerp is over het algemeen geen neutrale handeling, het kan iets minachtends of iets afstandelijks uitdrukken. Het lyrisch subject schuift zijn lichaam, dat hij nu als een ding ervaart, ter zijde. In deze actie klinken beide noties van 'schuiven', namelijk minachting en afstandelijkheid, door. Warmond gebruikt het woord 'schuiven" niẹt op een gebruikelijke manier: normaliter schuif je een voorwerp ergens in, maar geen levend wezen, geen lichaam. Door deze vergelijking wordt het voorwerpachtige van het lichaam benadukt. Het enjambement accentueert het tijdstip waarop dit proces zijn einde vindt: de avond, afsluiting van de dag, is het tijdstip waarop het leven wordt stilgelegd.

In de tweede strofe wordt het assonantiepatroon met dezelfde klank doorbroken als in de eerste strofe het geval was: 'bouwde' (r. 5) en 'toegevouwen' (r. 13). Er is een zeker verband tussen beide woorden: 'bouwde' leidt het proces in, terwijl 'toegevouwen' de eindfase daarvan aangeeft.

De laatste regels bevatten een vergelijking: 'als een zakelijk toegevouwen brief in een enveloppe'. In bepaalde gezinnen was het gebruikelijk 's avonds de kinderen bij het naar bed brengen in te stoppen 'als een postpakketje', er werd een postzegel, de nacht-zoen, opgeplakt en vervolgens werd het verstuurd naar dromenland. Ik weet niet of Warmond dit ritueel kent en eraan gedacht heeft. Het beeld in dit gedicht is niet zo vertederend. De gebruikte vergelijking is opmerkelijk, omdat het een verrassende tegenstrijdigheid bevat, die nog eens versterkt wordt door het enjambement. Aan de ene kant roept dit beeld op beklemmende wijze afstandelijkheid ('zakelijk', 'toegevouwen') en opgeslotenheid ('toegevouwen', 'enveloppe') op, aan de andere kant bevat het een communicatieve term: 'brief'. Deze term, die verwijst naar schriftelijke communicatie, ondermijnt de betekenis van de andere elementen van de vergelijking, hij impliceert immers het verlangen naar contact: open mij en 
lees mij. Het lijkt me niet toevallig, dat 'bouwde' en 'brief' allitereren. Zoals ik al eerder vermeldde, leidt 'bouwde' het depersonalisatieproces in, terwijl 'brief' een term is die aangeeft dat het lyrisch subject de daardoor ontstane distantie wenst te doorbreken. De deur leek gesloten, maar in de laatste regels wordt hij op subtiele wijze op een kier gezet.

In dit gedicht is er een spanningsveld tussen de 'Sartriaanse' vervreemding en het 'Merleau-Pontyaanse' verlangen naar contact. Vervreemding ontstaat op momenten dat het verlangen naar eenheid gefrustreerd wordt door uitsluiting, als er alleen-zijn is in plaats van de verwachte verbondenheid, aldus Merleau-Ponty. Het lyrisch subject uit 'Vereenvoudigde religie' legt zich uiteindelijk niet neer bij zijn situatie. De briefmetafoor geeft aan, dat er nog altijd verlangen naar contact is, maar dat juist de afwezigheid van dat contact de gevoelens van vervreemding versterkt.

Er zijn enkele passages in het werk van Warmond die meer licht werpen op deze problematick, zoals in Paspoort voor niemandsland. De hoofdfiguur Hans Erkelens bevindt zich door zijn ziekte in een existentiële crisis, waardoor hij radicaal op zichzelf wordt teruggeworpen. Deze gebeurtenis zet hem onder druk, hij wordt gedwongen tot reflectic en tot heroriëntatie op zijn situatie. Erkelens voelt zich steeds meer vervreemd van zijn lichaam. Er is slechts één manier waardoor de scheiding die teweeg is gebracht door het onteigeningsproces opgeheven kan worden, namelijk door de liefde en dan met name door de sexualiteit [accentuering door mij]:

"Alleen dárom verbergen mensen zich in de armen van andere mensen. Willen ze armen om zich heen voelen, die hen vasthouden; omdat het onmogelijk lijkt dat het [sterven] gebeuren zou zolang iemand je maar dicht genoeg bij zich vasthoudt. Omdat een mens, die zich vertrouwd heeft proberen te maken met zijn eigen dood, van zijn lichaam vervreemd is, zo zeer dat het zijn eigendom, zijn bezit niet meer is.

Hoogstens kan het dan nog eigendom zijn van een ander en door die ander aan hem teruggegeven worden." 36

De liefde kan de levenswalging elimineren. Ook in Warmonds poëtische werk blijkt de ander een cruciale rol te spelen in het opheffen van de vervreemding. In de bundel Warmte, een woonplaats, in hetzelfde jaar verschenen als de bovengenoemde roman, komen twee gedichten voor die dit illustreren. In 'Eerste en laatste' ${ }^{37}$ staat:

warmte

een lichaam van liefde

\section{dat zichzelf in een ander hervindt}

36 in: Puspoort voor niemandsland. Amsterdam 1961:97

37 in: Warmte, een uvonplaats Amsterdam 1961: 32 
daarbuiten is alles leegte

kou

verscheurende wind.

In 'Dit dan of meer' ${ }^{38}$ betekent geluk:

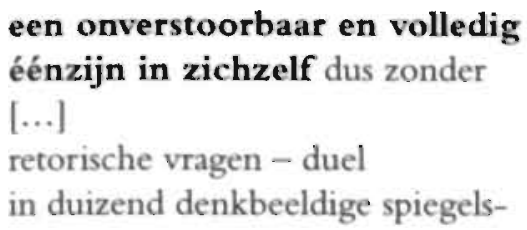

In het gedicht 'Omgekeerd perspectief ${ }^{39}$ bewerkstelligt de liefde niet alleen een eenwording met elkaar, maar ook een weer samenvallen met zichzelf:

wij passen weer in onze namen

sinds je er bent

ben ik weer alleen.

Hoe komt het, dat het lyrisch subject van het gedicht 'Vereenvoudigde religie' zo vervreemd is geraakt? Wat is zijn voorgeschiedenis? Het voorafgaand gedicht, ‘Chanson prèsque triste', werpt daar misschien wat meer licht op. Het gedicht laat zien hoe het lyrisch subject had willen zijn en wat daar uiteindelijk van terecht is gekomen. Je zou kunnen zeggen dat ideaalbeeld en realiteit samen een dubbelportret vormen en zelfs elkaars negatief zijn.

Lacan maakt onderscheid tussen Ideaal-ik en Ik-ideaal. ${ }^{40}$ Het Ideaal-ik is een imaginair beeld dat het subject nastreeft: dát zou hij willen worden, bijvoorbeeld een succesvol musicus of een beroemd advocaat. Het Ik-ideaal is het punt waaruit het subject wordt bekeken en beoordeeld, de blik waarvoor hij het Ideaal-ik zou willen zijn. Het Ik-ideaal kunnen de ouders zijn, of andere belangrijke voorbeelden in het leven van een kind, zoals leraren of andere familieleden dan de ouders. In 'Chanson presque triste" contrasteren ideaalbeeld en realiteit met elkaar. De cerste regels van het gedicht tonen het Ideaal-ik:

Hij beloofde zijn toekomst een spierdier

een technicolorpotentie

een bicepsbeeld. 
Deze accumulatio roept kracht, vitaliteit en glamour van een haast Hollywoodachtige allure op. Hoe anders is de realiteit:

een wirwartol verdwaald

in mierennesten haastige verwarring

voor honderden ogen een 1-oog.

In plaats van een succesvolle Tarzan, die zich in alle situaties weet te redden, is hij iemand geworden die overmeesterd wordt door het leven; hij is de weg kwijt. Wie of wat het Ik-ideaal is voor wie of waarvoor het lyrisch subject dit Ideaal-ik nastreefde, blijft onuitgesproken. Hem resten slechts gedesillusioneerdheid en zelfmedelijden, hij

omkranste zijn hunkerende spiegel

met slingers ach en wee

en sprak zichzelf vaak toe

mismoedig ....

'Chanson prèsque triste' en het daaropvolgende gedicht 'Vereenvoudigde religie' vormen samen een tweeluik, waarop een temporele ontwikkeling zichtbaar wordt: van gedesillusioneerdheid via zelfhaat naar depersonalisatie.

Rest ons nog in te gaan op de titel van het gedicht: 'Vereenvoudigde religie'. Het gedicht bevat de aanzet tot een dubbelportret van het lyrisch subject: het laat in een flits zijn verleden en wat uitvoeriger zijn huidige situatie zien. Door de keuzes die hij maakt, wordt het verleden naar de achtergrond verdrongen. Het gaat hier om de geloofsleer van het lyrisch subject. Hij gelooft zijn levenssituatie minder gecompli-ceerd te kunnen maken door te depersonaliseren, door zichzelf te reduceren tot object. Het is blijkbaar moeilijker de "god met de glimlach" aan te hangen dan de 'antigod", zijn tegenbeeld of negatief. Dat dit proces niet het verlangde einddoel is van het lyrisch subject, blijkt uit de briefmetafoor. Het verlangen naar contact breekt ondanks alles toch door de verdingelijking heen.

Samenvattend kunnen we zeggen dat Warmond de existentialistisch aandoende thematiek van dit gedicht zowel op linguïstisch als op poëtisch niveau zichtbaar en hoorbaar weet te maken. Hieruit blijkt een grote technische vaardigheid.

\section{Gesloten ruimtes}

In het literaire existentialisme vormen gesloten ruimtes als kelders, cellen of hotelkamers het decor waarin de strijd met zichzelf, met de ander of met de geïnternaliseerde ander plaatsvindt. Deze ruimtes visualiseren het existentiële isole- 
ment van het romanpersonage. In Paspoort voor niemandsland wordt die existentiële strijd vooral gestreden op pensionkamers en in hotelkamers. Opvallend in deze roman is, dat het motief van de gesloten ruimte verbonden wordt met het spiegelmotief. De ruimte wordt zodoende verder gereduceerd tot datgene wat in de spiegel zichtbaar is en dat is meestal het personage zelf. Deze close-up techniek accentueert samen met het decor van de gesloten, verengde ruimte de niet meer te ontlopen confrontatie met zichzelf. Een soortgelijke thematiek is terug te vinden in het gedicht 'Vereenvoudigde religie', waarin Warmond ook gebruik maakt van de confronterende close-up, waardoor niet alleen de kamer maar ook het eigen lichaam ervaren wordt als een voor anderen gesloten ruimte.

De poëzie van Warmond vertoont een breed scala aan gesloten ruimtes, al dan niet met een metaforische functie: onder andere een kamer, zolder, (schuil)kelder, kerk, verlaten straten, vitrine, trein, boot en moeras. In haar werk valt niet alleen de geografisch aanwijsbare ruimte daaronder, maar ook de spiegel, het eigen of andermans lichaam en natuurlijk 'de geheime proeftuin van mijn fantasie' waar Warmonds eerste bundel uit 1953 naar vernoemd is. Al deze ruimtes roepen vaak gevoelens op als wanhoop, angst, vervreemding, op zichzelf teruggeworpen zijn en verlangen naar contact met de ander. Een goed voorbeeld daarvan is het gedicht 'Woonhuis 1' uit haar eerste bundel. ${ }^{41}$ Van der Vegt stelt dat de ervaring die in dit gedicht verwoord wordt dezelfde is als die in de existentie-filosofie en in de daarmee verwante literatuur: het buiten zichzelf staan veroorzaakt walging en tast de vertrouwdheid van de onmiddellijke omgeving aan: ${ }^{42}$

\section{WOONHUIS 1}

De klok heeft geen geheugen meer een ongewone verbijstering kruipt zwijgend uit een hinderlaag een overdwars gespleten kegel draag:

ik. tussen schouders die me vreemd voorkomen

5. de muren tonen hun verwarrende profiel behangsels van herinnering die zich een uitweg wroeten een klokslag die een uur geleden viel

rolt als een trage damsteen voor mijn voeten twee dodelijk verschrikte handen liggen

10. als wezenloze vissen naast mijn bord waar is het huis en wat is deze kamer waarin ik langzaamaan een ander word?

41 in: Proefuin. Den Haag 1953: 11

42 Jan van der Vegt, 'Kijken in een gesloten spiegel.' Ons effdeel. Rekkem 1981, afl. 5, p. 655-664 
Van der Vegt beschouwt dit gedicht als een van de vele voorbeelden van Warmonds obsessie met de tijd. Tijd wordt ervaren als een tegenspeler, zoals blijkt uit de titel van de verzamelbundel Tegenspeler tijd uit 1979. De klokslag, een hoorbaar teken van de tijd, is op vervreemdende wijze gestold. Volgens Van der Vegt is deze tijdservaring te verbinden met de ideeën van de existentie-filosoof Heidegger over de tijd:

Evenals na hem Sartre ziet hij de tijd als een ervaring die ons in een leegte plaatst, waar we existerend ('buiten-staand') afgesneden zijn van wat voorbij is en ook van wat komen gaat. Elk tijdsmoment stort ons in het Niets en na de klokslag -als we terugkeren naar de beelden in het gedicht- is er een leegte. Wanneer de verbeelding dit tracht te vertragen, roept dit een ruimte van een surrealistische verschrikking op, waarin het ik zichzelf verliest, afgesneden van wat herkenbaar is. ${ }^{43}$

Van der Vegt associeert dit gedicht met de surrealistische schilderijen van Magritte, waarschijnlijk geldt dat vooral voor het beeld van de 'twee dodelijk verschrikte handen die als wezenloze vissen" naast het bord liggen. Dit gedicht roept ook nog werk van een andere schilder op: het beeld uit de derde regel doet denken aan een schilderij van De Chirico, waarin het lichaam tot basale geometrische vormen is teruggebracht, terwijl het vervreemdende effect versterkt wordt door een realistische weergave van de omgeving.

Gevoelens als angst en wanhoop figureren vaak in een existentialistische context. Zij zijn uitingsvormen van de vervreemding, maar dan op prereflexief niveau. In Paspoort voor niemandsland zijn soortgelijke belevingen te vinden als in 'Woonhuis 1'. In de afscheidsscène in de stationsrestauratie realiseert Hans zich dat zijn relatie met Eva geen lang leven beschoren is. Op dat moment raakt zijn blik vervreemd:

Hij sloeg zijn ogen neer en keek naar het geruite tafelkleedje. Zijn hand lag precies vijf blokken van de hare vandaan. Scheef, hortend, als een gewond reptiel, kroop die hand die vijf blokken langs en schoof zich over de hare. Parende spinnen. Maar hij nam zijn hand niet weg. (147-148)

In zijn artikel besteedt Van der Vegt weinig aandacht aan de literaire vormgeving van bovengenoemd gedicht. ${ }^{44}$ Een alleen op de inhoud gerichte bespreking doet geen recht aan de complexiteit van Warmonds poëzie. Het loont de moeite haar werk op diverse poëtische niveaus te onderzoeken, aangezien vorm en inhoud nauw met elkaar verbonden zijn: de thematiek klinkt door in metrische structuur, grammaticale presentatie, beeldentaal en klankstrucuur. Daarom ga ik nu dieper in

43. Jan van der Vegt 1981: 657

44 Mejer 1988: 300-302 schenkt in een korte bespreking van dit gedicht wel enige aandacht aan de literaire vormgeving. Ze wijst er met name op, dat het procédé van de personificatie de vervreemding accentueert. 
op enkele poëtische aspecten die de existentialistische inhoud van 'Woonhuis 1' mede (uit)dragen.

Allereerst de metrische structuur. Het gedicht bestaat uit een afwisseling van overwegend vijf- en zesvoetige jamben. Het jambische ritme lijkt op het regelmatige tikken van een klok, iets wat in dit gedicht verbazing wekt, aangezien de stolling van de tijd een belangrijk motief is in dit gedicht. De klok geeft geen tijd meer aan of in ieder geval niet meer de juiste tijd. Het jambische ritme gaat als het ware tegen de inhoud van het gedicht in. Het lijkt alsof hiermee aangegeven wordt dat dé tijd gewoon doorgaat en alleen de ervaringstijd van het lyrisch subject aangetast is. Ook het woord 'voorkomen' (r: 4), dat bovendien door een antimetrie extra aandacht krijgt, geeft aan dat hier sprake is van een particuliere, subjectieve ervaring.

Een andere antimetrie vormt het woord 'rolt' (r. 8), dat in tegenstelling tot de andere beginwoorden een accent krijgt. In die hele achtste regel roept Warmond door middel van een verrassend ruimtelijk beeld het stollingsproces van de tijd op. Het rollen, dat nog een zekere snelheid suggereert, vertraagt al enigszins in het beeld van de trage damsteen om tenslotte geheel tot stilstand te komen voor de voeten van het lyrisch subject.

Zoals ik al opmerkte, bestaat het gedicht uit vijf- en zesvoetige jamben. Er is één uitzondering: 'behangsels van herinnering die zich een uitweg wroeten' (r. 6) bestaat uit zeven versvoeten. Deze regel heeft door de extra versvoet een stotend effect, alsof daarmee het moeizame van het wroeten geaccentueerd wordt.

Vervreemding gaat niet alleen samen met een andere tijdsbeleving, maar ook met een andere lichaamsbeleving. In vervreemde toestand wordt het lichaam niet langer ervaren als Leib, maar als Körper, als een object. Dat proces is halverwege het eerste kwatrijn al begonnen:

een overdwars gespleten kegel draag

ik tussen schouders die me vreemd voorkomen

Deze regels zijn opmerkelijk, niet alleen door het gebruikte beeld maar ook door de grammaticale structuur. Je zou verwachten dat de overdwars gespleten kegel verbazing zou oproepen, maar uitgerekend de lichaamsdelen die nog iets menselijks hebben, namelijk de schouders, komen het lyrisch subject vreemd voor. Deze omkering is kenmerkend voor vervreemding: dingen worden gepersonifieerd, terwijl mensen of menselijke onderdelen verdingelijkt worden. In De myte van Sisyfus (1942) brengt Camus een fasering aan in de absurditeitservaring: het begint met een gevoel van verveling, vervolgens worden objecten als vreemd ervaren en tenslotte ervaar je jezelf of de ander als een vreemde. Het lyrisch subject bevindt zich in de tweede en gedeeltelijk al in de derde fase. De klok en de muren zijn al gepersonifieerd, maar de vervreemding heeft de lichaamsbeleving nog niet geheel en al aangetast, aangezien de schouders nog net als zodanig herkend worden, in tegenstelling tot het hoofd. 
Niet alleen de beleving van de tijd maar ook de beleving van de ruimte is in dit gedicht anders dan gewoonlijk. Hoe valt dit te verklaren? Ruimtelijke aspecten als diepte, hoogte en breedte zijn een betrekking tussen mij en de dingen, aldus Merleau-Ponty in Fenomenologie van de waarneming (1945/1997). De existentie is ruimtelijk, dat wil zeggen dat zij zich uit innerlijke noodzaak naar een 'buiten' openstelt. Existeren is immers 'naar de wereld gericht zijn'. Het lichaam neemt niet als een object ruimte in, maar het bewoont de ruimte.

In De psychiatrische patiènt (1964) vergelijkt de fenomenologische psychiater J. H. van den Berg de relatie van lichaam en wereld met een dialoog. ${ }^{45}$ Het lichaam neemt een bepaalde houding aan die in overeenstemming is met de wereld waarin zijn taak ligt. Zo kan het lichaam een vechtgestalte of een liefdesgestalte aannemen. Maar de wereld verandert ook door het lichaam dat daarin beweegt. De dingen zien er voor een strijdlustig iemand immers anders uit dan voor een vredelievend persoon. Ze ervaren beiden de dingen op een andere wijze, aldus Van den Berg. Ook een ziekte kan ervoor zorgen dat iemand de dingen anders ervaart dan voorheen. Voor de depressieve patiënt is alles om hem heen somber geworden, terwijl de manisch gestoorde patiënt alles kleuriger ziet dan voorheen. Van den Berg geeft het voorbeeld van iemand die op straat het idee heeft dat de huizen bijna op hem neervallen. Dat betekent dat zijn eigen bestaan op het punt van instorten staat en dat hij leeft met de relicten van een voorbije tijd. Maar ook voor 'gewone' mensen geldt, dat ieder een eigen beleving van de ruimte heeft, afhankelijk van leeftijd, geslacht, opvoeding, beroep, intelligentie en dergelijke. Ook zij zien zichzelf terug in de manier waarop ze de ruimte beleven, aldus Van den Berg.

In het gedicht 'Woonhuis 1' wordt de beleving van de ruimte onder invloed van de vervreemding zodanig vervormd, dat het lyrisch subject zich niet meer kan orienteren en dit resulteert in de vragen: 'waar is het huis en wat is deze kamer' (r. 11)? Het is alsof de kamer een losstaande ruimte is, zonder enige verbinding met een groter geheel. Omdat het grotere geheel, het huis, onbekend is, is het onmogelijk te bepalen welke functie de kamer heeft ten opzichte van dat geheel: is het een woonkamer, een studeerkamer, een sterfkamer? Deze ruimtebeleving illustreert dat het lyrisch subject op dat moment nog geen richting aan zijn leven kan geven. Aan de ene kant drukken de vragen desoriëntatie uit, aan de andere kant zijn ze pogingen om zich te oriënteren, om het verband te herstellen.

De vervreemding, de ervaring van het absurde ontstaat uit de confrontatie tussen het menselijke verlangen naar eenheid en de als redeloos en versnipperd ervaren wereld. Maar deze ervaring zorgt er ook voor, dat iemand bewust gaat nadenken. over zijn bestaan. Door de verveling wordt zijn bewustzijn wakker geschud. Hij kan terugkeren naar de sleur van vroeger of voorgoed wakker worden, aldus Camus. ${ }^{46}$ Het lijkt alsof het lyrisch subject in 'Woonhuis 1' het af zal gaan leggen tegen de

45 J.H. van den Berg, De psychiatrische patiënt. Kleine algemene psychopathologie op fenomenologische grondslog. Nijkerk 1964

46 Albert Camus, De myte uan Sisyfus. Een essay over het absunde. Amstendam 1975: 19 
vervreemding. Toch zijn er signalen die wijzen op de mogelijkheid van een andere afloop. Net als in sommige andere gedichten van Warmond duiken er op onverwachte wijze termen op die tegen de teneur van het gedicht ingaan. In het gedicht 'Vereenvoudigde religie' bijvoorbeeld bleken de woorden 'brief' en 'envelop' communicatieve signalen te zijn van een lyrisch subject dat deed voorkomen naar ijzige afgeslotenheid te streven. Iets soortgelijks gebeurt in het gedicht 'Woonhuis 1'. Allereerst zijn er aanwijzingen dat het vervreemdingsproces nog niet helemaal voltooid is: hoewel de schouders vreemd aandoen, worden ze nog wel als schouders herkend; de vragen in r. 11 zijn pogingen om het verband te herstellen en de woorden 'langzaamaan en word' in de laatste regel geven aan dat het proces nog niet afgerond is. Er is echter nog een andere aanwijzing en wel op het niveau van de assonantie. Door het gedicht heen geven de woorden met een ui-klank als het ware een ontsnappingsroute aan: kruipt (r. 2) > uit (r. 2) > uitweg (r. 6) > huis (r. 11). De regel 'behangsels van herinnering die zich een uitweg wroeten' (r.6) interpreteer ik dan ook anders dan Meijer en Van der Vegt. Meijer stelt dat de herinneringen zich tevergeefs een uitweg zoeken. Ze worden voorgesteld als behangpatronen, die niet in staat zijn zich te bevrijden van de muur. ${ }^{47}$ Van der Vegt interpreteert de regel als het wegrotten van de herinneringen, waardoor niets meer herkenbaar is. ${ }^{48} \mathrm{Ik}$ leg daar een andere visie naast. De tijd mag dan geen geheugen meer hebben, maar impliceert dit dat het geheugen geen tijd meer kent? Tegen de vervreemding in proberen de herinneringen toch naar boven te komen, ze wroeten zich een uitweg. De identiteit van een mens wordt immers onder meer bepaald door de herinneringen; zodra die er niet meer zijn verliest hij zijn identiteit en zal de vervreemding voltooid zijn. Regel 6 is een van de aanwijzingen waaruit blijkt, dat het lyrisch subject zich nog niet volledig uitlevert aan de vervreemding. Net als in 'Vereenvoudigde religie' verlangt het lyrisch subject onderhuids naar verlossing door de ander, maar dat blijkt pas echt duidelijk aan het eind van het vervolggedicht, 'Woonhuis II':

Dit noemt men huis deze kubus oorverdovende leegte met ramen die iets verbergen en stoelen die samenzweren

5. de vuurmond van een lamp die op de schietschijf van de open wijdopen pupil staat gericht dat noemt men licht 
deur die gesloten blijft

10. bel die niet overgaat

eenzaamheid

onraad

\section{Geseculariseerde invulling van christelijke begrippen}

Eén van de kenmerken van het literaire existentialisme is, dat christelijke begrippen vanuit een antropocentrisch perspectief worden geherinterpreteerd. ${ }^{49}$ In de roman Paspoort voor niemandsland bijvoorbeeld krijgen elementen uit de bijbel als het scheppingsverhaal, de lijdende Christus en het verraad van Petrus een aardse, op de mens gerichte invulling. Hoewel dit kenmerk in Warmonds poëzie niet zo pregnant aanwezig is, zijn er toch wel enkele voorbeelden van te vinden: 'Hagepreek' en 'Achter glas' uit Weerszij van een wereld (1957), 'Ondeelbaar' (Het struisvogelreservaat 1963), 'Bidstonde' (De huid als raakvlak 1964), 'Bij de tijd' (Geen bloemen geen bezoek 1968) en 'New map of Via Dolorosa' (De groeten aan andersdenkenden 1970). In deze gedichten makt Warmond gebruik van een en hetzelfde procédé: de al dan niet ironische herschrijving van christelijke tekstelementen of formules. Dit procédé werd overigens ook al vóór het literaire existentialisme toegepast. Het bekendste voorbeeld is waarschynfijk de derde strofe van sonnet CVI uit de Mathilde-cyclus. van Jacques Perk: ${ }^{50}$

Schoonheid, on Gij, Wier naam geheiligd zij,

Uw wil geschiede; kóme Uw heerschappij;

Naast $U$ aanbidde de aard geen andren god!

In de tweede strofe van het gedicht 'Bidstonde' bijvoorbeeld wordt het 'Onze Vader' herschreven ${ }^{51}$ :

Wij vormen een geruchtmakend verschijnsel

een onbedaarlijk maar ongevaarlijk

soort waanzin een mesdunne lijn

van genot snijdt de hemel open

5. en dompelt ons in gemompel

van subtiel versneden gebeden:

geef ons heden ons en vergeef ons

gelijk ook wij en leid ons

49 zie H. van Stralen 1996: 69-70. In plats van de door hem gebruikte term 'antropocentrisch' gebruik ik liever de term 'geseculariseerd'.

50 in: Jacques Perk, Gedichten. Tiende en geheel volledige uitgave bezorgd door Willem Kloos. Amstendam 1911: 143

51 in: De haid als nakvlak. Amsterdam 1964: 15 
niet maar verlos ons want wij

10. regeren samen

het koninkrijk amen.

Warmond volgt gedeeltelijk de structuur van dit nieuwtestamentische gebed. Het zijn echter vooral de afwijkingen van deze vertrouwde tekst die een geheel andere visie met zich meebrengen dan die van het christelijke model. De bekendheid met dit gebed schept bepaalde verwachtingen ten aanzien van het vervolg, maar iedere keer als de lezer meent de oorspronkelijke tekst aan te kunnen vullen vindt er een verrassende wending plaats. De horizontale gerichtheid blijkt uit de afwezigheid van de klassieke aanspreking; ('Onze Vader die in de hemelen zijt'), en het herhaaldelijk gebruik van de voornaamwoorden 'wij' en 'ons'. Ook de regels 'Uw Koninkrijk kome, Uw wil geschiede, gelijk in de hemel, alzo ook op de aarde ${ }^{52}$ ontbreken in dit gedicht. Het koninkrijk waar hier naar verwezen wordt bevindt zich niet aan gene zijde, maar in het hier en nu van de gezamenlijk beleefde liefde. In de regel 'een mesdunne lijn / van genot snijdt de hemel open' klinken verschillende allusies door die allemaal duiden op groot geluk: 'in de zevende hemel zijn' en 'een hemel op aarde'. De titel van het gedicht bevat een allusie op een bepaald tijdstip dat voor het bidden gereserveerd wordt en/of op de speciale kerkdienst warin voor een speciaal doel gebeden wordt, bijvoorbeeld de bidstonde voor het gewas. De bidstonde is in dit gedicht echter het moment waarop de geliefden elkaar beminnen. Hier doet zich een interessante omkering voor: het lyrisch subject heeft zich aan de ene kant losgemaakt van de godsdienst, aan de andere kant wordt de liefde in een religieus aandoende sfeer geplaatst. De liefde is als het ware gesacraliseerd. Dat deze visie in de loop der tijd niet essentieẹi is veranderd, blijkt uit één van de laatste bundels van Warmond. Aan het eind van het gedicht "Wie zich vergist heeft gelijk' staat ${ }^{53}$ :

\section{als God is Liefde (vooral vice versa)}

hebben minnaars het ware geloof

Terug naar 'Bidstonde'. De traditionele regel 'geef ons heden ons dagelijks brood' wordt herschreven tot 'geef ons heden ons'. Klinkt hier misschien als verre echo een passage uit het Mattheusevangelie in door? In Mattheus 4: 4 staat: 'niet alleen van brood zal de mens leven", waarmee bedoeld wordt dat de mens ook hogere dan alleen aardse behoeften heeft. Deze 'hogere' behoefte is voor het lyrisch subject de liefde, die belangrijker en essentiëler is dan wat ook. Ze is broodnodig.

De geliefden uit 'Bidstonde' vragen geen erkenning en zeker niet aan God, zij wensen hun liefde te beleven in een vanzelfsprekend genieten. Ze verbinden zich niet met de door het christendom beïnvloede normen en waarden. Het daaruit

52 ik ga hier uit van de vertaling van het Nederlands Bijbel Genootschap (NBG)

53 in: Kaalslog. Amstendam 1999:51 
voorkomende zondebesef wijzen ze af. In 'Bidstonde' wordt niet zoals in de oorspronkelijke versie gesproken van 'schulden', 'schuldenaren', 'verzoeking' en 'de boze'. Het schuldelement ontbreekt hier geheel. Ook de regel 'Want van $U$ is het Koninkrijk' is herschreven. De geliefden achten zich geheel autonoom, dat wil zeggen niet genoodzaakt verantwoording af te leggen aan een hogere instantie, wie. of wat dat dan ook zijn moge. Dit antropocentrisme verlegt het accent van God naar de individuele mens. Hieruit spreekt affiniteit met de atheistische variant van het existentialisme, onder meer vertegenwoordigd door Sartre en Camus, waarin het volle accent op het leven hier en nu ligt. Godsdienst en menselijke vrijheid zijn in deze visie onverenigbaar, omdat de mens in de scheppingsverhalen als een maakding gepresenteerd wordt.

Interessant is de ambiguiteit van het werkwoord 'vergeven', dat naast 'vergiffenis schenken' ook 'aan een ander geven" kan betekenen. Gezien de context van het gedicht treedt vooral de laatste betekenis naar voren. De regel 'geef ons heden ons en vergeef ons' zou je kunnen interpreteren als: laten we ons nu aan elkaar geven in liefdevolle verbinding. Ook het werkwoord 'verlossen' is in dit gedicht meerduidig op te vatten: niet alleen als 'bevrijden', maar ook als 'losser maken' en 'geboren laten worden'. Zo geinterpreteerd wordt hier een oproep gedaan aan zichzelf en aan de geliefde om elkaar te bevrijden uit een belemmerende rationaliteit. Door losser te worden -een van de sleutelbegrippen in Warmonds werk die verwijzen naar de directheid van de ervaring- kunnen de geliefden hun lichaam als 'Leib' beleven. Deze ervaring voelt aan als een herboren worden.

In tegenstelling tot het 'Onze Vader' wordt de herschreven versie niet als één gebed gepresenteerd, maar als 'gebeden' (r. 6). Komt dat, omdat de allesomvattende context van de godsdienst er niet meer is? Feit is in ieder geval, dat ieder aspect zo meer aandacht krijgt, overigens mede door de 'weggelaten' elementen. De woorden 'subtiel versneden gebeden' geven niet alleen aan, dat er sprake is van een andere versie, maar zelfs van een subtiel verbeterde versie. Het werkwoord 'versnijden' betekent immers zowel 'anders snijden' als 'op de juiste wijze snijden'. Het kan ook een negatieve connotatie hebben (bijvoorbeeld in 'wijn versnijden'), maar dat lijkt me in dit gedicht niet aannemelijk, aangezien het verwante werkwoord 'snijden' in de vierde regel duidelijk een positieve betekenis heeft.

Ook het gedicht 'Achter glas' bevat een allusie op het 'Onze Vader'. ${ }^{44}$ Net als in 'Bidstonde' wordt het 'dagelijks brood' uit de oorspronkelijke versie van het gebed vervangen door iets anders:

$[\ldots]$

ik kan wel bidden maar niet anders

dan geef ons heden ons dagelijks lichaam

en kleed ons met de huid van de beminden

54 in: Werszij man een wereld. Den Haag 1957:50 
Hiermee wordt gesuggereerd dat ons lichaam van essentieel belang is en dat de liefde een essentiële levensbehoefte is. In beide gedichten ('Bidstonde' en 'Achter glas') speelt de beleving van de lichamelijkheid een belangrijke rol. In de volgende paragraaf ga ik daar verder op in.

Een ander voorbeeld van een geseculariseerde invulling van christelijke begrippen is het gedicht 'New map of Via Dolorosa $1{ }^{\prime},{ }^{55}$ In plaats van de lijdensweg van Christus wordt hier met gebruikmaking van klassiek-christelijke lijdenstermen als Via Dolorosa, staties en Golgotha, de lijdensweg opgeroepen van de zwarte jazz- en blueszangeres Bessy Smith, die bekend staat als 'the Empress of the Blues'. Ze overleed in 1937, nadat ze na een auto-ongeluk door het ene na het andere blanke ziekenhuis geweigerd werd.

In de bijbelpassage waarnaar in het begin van het gedicht verwezen wordt, vragen de hogepriesters en de schriftgeleerden aan Jezus wie hem de bevoegdheid gegeven heeft om in de tempel onderricht te geven aan het volk. ${ }^{56}$ Deze verwijzing bevat een indirecte kritiek op de manier waarop Bessy Smith behandeld werd: met welk recht gebeurde dat? Via de uitwerking van de uitspraak 'She is black' (r. 3) bekritiseert Warmond in dit gedicht niet alleen het masculinistisch fundament van het geinstitutionaliseerde christendom, maar ook de racistische teneur daarvan in het zuiden van Amerika.

\section{NEW MAP OF VIA DOLOROSA}

Vraag naar Jezus' bevoegdheid LUCAS 20:1

Als de astronaut die god zag (en op de vraag naar het hoe en wat antwoordde 'SHE IS BLACK') nu eens gelijk had ...

5. wie zegt dan dat bijvoorbeeld Bessy Smith (geweigerd door het ene na het andere hospitaal langs alle blanke staties in Memphis, Tennessee, ${ }^{57}$ en bij de laatste onherstelbaar dood

10. gearriveerd) daar niets mee te maken had?

55 in: De gneten aan andersdenkenden. Amsterdam 1970: 18

56 in feite wordt de vraag pas in Lucas 20: 2 gesteld: 'Zeg ons welke bevoegdheid Gij hebe om dit alles te doen? En wie heeft $U$ die bevoegdheid dan gegeven?'

57 volgens de encyclopedie stierf Bessie Smith in Clarksdale (Misissippi), dat ten zuidwesten van Memphis ligt. Misschien is ze darna overgebracht nax Memphis? 
dat opent perspectieven voor

een nieuw Amerikaans toerisme

en niet veel minder lonend lijkt me

15. dan oorlogsindustric

want waar blijven ze dan op Golgotha

met dat kruis en die doornenkroon

dat was tenslotte de zoon nog maar

but we Americans in Gods own country

20. (de naam immers zegt het al)

wij hebben de enig echte

we've got the King Size Queen.

Het oudste Warmondiaanse voorbeeld van een geseculariseerde invulling van christelijke begrippen dateert uit 1957 . Het gedicht 'Hagepreek' ${ }^{58}$ bevat allerlei allusies op uitdrukkingen en zinswendingen die in een kerkelijke context thuishoren. Door een subtiele verschuiving in de vertrouwde formulering, zoals in 'vergeving van geliefde zonden' en 'heer verlos ons van de pose', krijgt de tekst een scherpe sfeer, waarin kritiek doorklinkt op de hypocrisie van sommige gelovigen:

\section{IAGEPREEK}

(te houden op de laatste

zondag van de vrede)

Hier misschien wel niet

en elders desnoods anders ...

5. maar zij die niet geloven in

het batig saldo van het laatste salvo

die niet meer willen spelen met

de bouwplaat kartonnen vrede

de legpuzzel waarin

10. de stukken niet en nooit

precies aan het misschien te passen zijn

laten zij bidden 
niet om vergeving van geliefde zonden

niet om het heer verlos ons van de pose

15. maar om de allerlaatste

onverzettelijke vloek

om nee en nee en nee

en nee voorgoed.

Ook dit gedicht is een voorbeeld van de manier waarop Warmond van allerlei poëtische middelen gebruik maakt om de thematiek nog meer reliëf te geven. Het verzet tegen oorlog en geweld, waartoe dit gedicht oproept, klinkt al door in de titel: een hagenpreek was een door de autoriteiten verboden, opruiende preek in het open veld in de eerste tijd van de Hervorming. De herhaling van het ontkennend bijwoord 'niet', dat maar liefst zes keer in het gedicht voorkomt, is als het ware al een opmaat naar de climax in de laatste strofe. De nuancerende antithese (niet $x$ maar y), de anafoor in r. 13-14 én de herhaling in r. 17-18 ('nee en nee en nee en nee') accentueren de onverzettelijkheid van de vloek. Warmond gebruikt daartoe nog een ander poëtisch middel, namelijk de antimetrie. Het gedicht heeft op enkele kleine afwijkingen na een jambische structuur, alleen r. 16 ('onverzettelijke vloek') is opgebouwd uit trocheeën. Het tegendraads ritme van deze antimetrie beklemtoont aldus het protest waartoe het gedicht oproept.

\section{Lichaamsbeleving}

Evenals het gedicht 'Vereenvoudigde religie' vertonen diverse andere gedichten van Warmond verwantschap met een objectiverende lichaamsbeleving, waardoor het lichaam als Körper wordt ervaren. Ik roep de laatste regels van 'Vereenvoudigde religie' nog eens in herinnering ${ }^{59}$ :

zo won hij dagelijks afstand

tot hij ten slotte zijn lichaam

onteigend' had en het 's avonds

tussen zijn lakens schoof

als een zakelijk toegevouwen

brief in een enveloppe.

Ook de roman La Nausée (1938) van Sartre is daar een duidelijke exponent van. In deze roman wordt de hoofdpersoon overspoeld door walging en angst. De gedesillusioneerde Roquentin gaat zichzelf in de spiegel -maar ook daarbuiten- steeds meer ervaren als object. Het grijze ding in de spiegel blijkt hij bij nader inzien zelf te zijn. Een paar dagen vóór de komst van Anny, zijn geliefde, krijgt hij een angstaanval. Hij voelt zich achtervolgd en overmeesterd door het bestaan,

59 in: Naar men zegt. Den. Haag 1955: 33 
geintensifièerd door zijn eenzaamheid. In de volgende passage wordt het begin van het vervreemdingsproces zichtbaar, de identiteit van Roquentin dreigt te vervagen, hij verandert in een onbekende. De hoofdfiguur duidt zichzelf niet meer aan met 'ik' maar met 'hij':

'ik raak buiten adem, hij zegt dat hij buiten adem raakt [...] op slinkse wijze word ik gedwongen te denken, dus iets te zijn, achter me terwijl ik ijle bellen bestaan uitblaas, hij is een luchtbel, een nevel van begeerte, in de spiegel is hij bleek als een dode [...]Antoine Roquentin is niet dood, van de aardbodem verdwijnen: hij zegt dat hij zou willen verdwijnen, hij holt $[\ldots]^{60}$

Eerder in het verhaal wordt Roquentin niet alleen doordrongen van de contingentie van zijn eigen bestaan, maar van ieder bestaan. Het bestaan ervaart hij als absoluut en onherleidbaar. Een traditionele bestaanshiërarchie, zoals in veel scheppingsverhalen waarin de mens de kroon der schepping is, acht hij uitgesloten als basis van zijn levensbeschouwing. Door dit toevalligheidsbesef ervaart Roquentin zijn bestaan als zin-loos:

Mijn komst op de wereld berustte op toeval, ik bestond zoals een steen, een plant of een microbe bestaat. ${ }^{61}$

Wel, geen enkel noodzakelijk zijn kan het bestaan verklaren: de contingentie is geen valse schijn, geen uiterlijkheid die je kunt wegvagen; het is het absolute, en dientengevolge volmaakt vrijblijvend. Alles is vrijblijvend, het park, de stad en ik zelf. Als het moment gekomen is dat je dat gat beseffen, duizelt het je en begint alles te zweven [...]: dat is de Walging [... $]^{62}$

Er vindt een interessant proces plaats: Roquentin ervaart zijn lichaam steeds meer als een object, als een ding waarin het bestaan zich manifesteert:

De hand trekt een beetje aan mijn arm, ternauwernood, voorzichtig, aarzelend, de hand bestaat. Ik geef het op: waar ik mijn hand ook leg, ze gaat door met bestaan en ik zal blijven beseffen dat ze bestaat. Ik kan niet van mijn hand afkomen, evenmin als van de rest van mijn lichaam $[\ldots]^{63}$

Tegelijkertijd worden de dingen gepersonifieerd. Ze verliezen hun instrumentele functie en dreigen als het ware een eigen leven te gaan leiden:

60 Jean-Paul Sartre, Walping. Amsterdam $1990^{11}: 144-145$

61 ibid.: 120

62 ibid.: 182

63 ibid. 140 
ik voelde in mijn hand een koud voorwerp dat mijn aandacht trok doordat het een soort eigen leven was gaan leiden. Ik deed mijn hand open en keek: ik hield gewoon de deurknop vast, dat was alles. ${ }^{64}$

Dingen [...] Je gebruikt ze, je zet ze terug op hun plaats, je leeft ermee: ze zijn nuttig, meer niet. En mij raken ze, afschuwelijk. Ik ben bang met ze te maken te krijgen, alsof het levende wezens zijn. ${ }^{65}$

In de visie van existentiële fenomenologen hangt de beleving van het lichaam samen met bepaalde bewustzijnsgraden, zoals ik in een eerder hoofdstuk heb besproken. In het eerstegraads bewustzijn ervaar ik mijn lichaam als 'Leib', In het tweedegraads bewustzijn kan ik dankzij de introspectie naar mezelf kijken alsof ik een ander was. Op die momenten ervaar ik mijn lichaam als 'Körper': mijn lichaam als object en instrument voor de ander, waarbij 'de ander' een ander mens kan zijn of het reflecterend ik. Deze lichaamsthematiek is bij Warmond niet gebonden aan een bepaalde periode, ze komt namelijk ook in latere bundels voor. Ik wees al eerder op het gedicht 'Eenvoudig', waarin deze twee lichaamsbelevingen voorkomen $^{66}$ :

\section{EENVOUDIG}

De huid vanzelsprekend

bewonen

het bloed

zijn werk laten doen

5. de hand laten grijpen

niet tasten

het oog laten zien

niet ontleden

het denken laten varen

10. kon ik dat maar. 
De lichaamsbeleving die bij het eerstegraads bewustzijn hoort, de beleving van het lichaam als 'Leib', is te vinden in r. 1-5 ('De huid ... laten grijpen'), in r. 7 ('het oog laten zien') en in r. 9 ('het denken laten varen'). Het gedicht kent een zekere dynamiek: afwisselend is de aandacht van de lezer op de buitenkant of op de binnenkant van het lichaam gericht: 'huid', 'bloed', 'hand', 'oog'. In r. 9 gaat de aandacht nog meer naar binnen: van het 'oog' naar het 'denken', dat traditioneel in de hersenen gesitueerd wordt, om uiteindelijk terecht te komen bij degene in wie dit alles samenkomt: het lyrisch subject.

De derde en vierde strofe zijn opgebouwd volgens het principe van de nuancerende tegenstelling ('laten grijpen / niet tasten' en 'laten zien / niet ontleden'). Hierdoor krijgen de eerste termen van de antithese meer aandacht en reliëf.

Het gedicht kent een parallelle structuur: een opeenvolging van vijf infinitiefgroepen, waardoor een programmatisch effect ontstaat. Deze groepen bevatten samen als het ware het beginselprogramma van het lyrisch subject. De parallellie suggereert ook simultaneiteit en samenhang; de in r. $1 \mathrm{t} / \mathrm{m} 9$ genoemde acties zouden gelijktijdig en samenhangend met elkaar kunnen geschieden, ware het niet dat het ik dit blokkeert. De gewenste ervaring is blijkbaar alleen mogelijk als het ik of het ego naar de achtergrond verdwijnt. Tot in de syntactische structuur weet Warmond dit thema zichtbaar te maken. In de infinitiefconstructies is er immers geen sprake van een ik, het subject is afwezig. Bovendien wordt er geabstraheerd van modaliteit: is er sprake van willen, moeten, kunnen, zullen? Pas door het imperfectum in de laatste regel wordt duidelijk dat we hier te maken hebben met een wensmodaliteit: het programma uit de regels $1 \mathrm{c} / \mathrm{m} 9$ is een wens van het lyrisch subject, maar vooralsnog een irrealis. Vooralsnog, want er zijn situaties waarin deze ervaring wel mogelijk is. Ik kom hier in hoofdstuk XI op terug.

Er zijn echter situaties waarin er eerder sprake is van dualisme, van een

Twistgesprek binnen de huid tussen bloed en verstand ${ }^{67}$

In 'Eenvoudig' verlangt het lyrisch subject naar het reageren vanuit het gevoel ('het bloed. / zijn werk laten doen [...] het denken laten varen'), naar de directheid van de ervaring ('grijpen / niet tasten') en naar synthese in plaats van analyse ('zien / niet ontleden'), zonder tussenkomst van een reflecterend en rationaliserend $\mathrm{lk}$. De titel van het gedicht vat dit alles als het ware samen: het gaat om het verlangen naar ongecompliceerdheid en het opheffen van dualiteit. Kortom, naar de pre-reflexieve ervaring.

Interessant is het gebruik van het werkwoord 'laten' in dit gedicht. Het betekent 'veroorzaken/maken' of 'toelaten/niet verhinderen' dat iets gebeurt. In 'Eenvoudig' hebben de infinitiefconstructies een ambigue structuur: beide voornoemde betekenissen van 'laten' kunnen hier aan de orde zijn. Betekent bijvoorbeeld 'het bloed /

67 'Röntgenologie' uit: De haid als nakvlak, Amstendam 1964: 59 
zijn werk laten doen' dat het lyrisch subject de voorwaarden schept om dat te bewerkstelligen? Of betekent het dat het lyrisch subject niets hoeft te doen, het alleen maar moet toelaten? Of impliceren beide mogelijkheden elkaar: door het toe te laten schept het lyrisch subject de voorwaarden voor het ontstaan van het beoogde effect? Ook de andere elementen uit de opsomming kennen deze ambigue structuur. In ieder geval moet de reflexieve ervaring die verbonden is met het tweedegraads bewustzijn vervangen worden, zoals al aangegeven is in de van het subject abstraherende infinitiefconstructies en het gebruik van het absoluut-categoriaal lidwoord ('de huid' in plaats van 'mijn huid' enz.). Aan het eind echter komt het lyrisch subject ineens in beeld, daardoor komt de laatste regel des te harder aan: 'kon ik dat maar'. Het reflexieve ik blokkeert de beleving van het lichaam als 'Leib'. waardoor het tegenbeeld van het wensprogramma wordt opgeroepen: de huid wordt niet vanzelfsprekend bewoond, het bloed kan zijn werk niet doen, de hand tast in plaats van te grijpen, het oog ontleedt in plaats van te zien en het denken kan niet worden losgelaten. Het lichaam wordt ten gevolge daarvan ervaren als 'Körper', als instrument. Het is overigens niet duidelijk of de onmacht in dit gedicht slechts tijdelijk is -gebonden aan een bepaalde situatie of fase- of kenmerkend is voor het gehele leven van het lyrisch subject.

Ook in andere gedichten van Warmond is deze Körperervaring gethematiseerd. In het al eerder besproken 'Vereenvoudigde religie' beleeft het lyrisch subject zijn lichaam als een object, 'als een zakelijk toegevouwen / brief in een enveloppe'. Dit hoeft overigens niet per se gepaard te gaan met een afkeer van het lichaam. Wel gaat het vaak samen met desintegratie ten gevolge van vervreemding, het lichaam lijkt dan in onderdelen uiteen te vallen. Door heel Warmonds werk komt een objectiverende lichaamsbeleving én het verlangen daaraan te ontsnappen terug, vanaf haar eerste bundel Proeftuin (1953) tot aan Kaalslag (1999). Een vroeg voorbeeld van het eerste aspect is het al eerder besproken gedicht "Woonhuis $1^{, 68}$, waarin de vervreemding door middel van surrealistische beelden wordt opgeroepen en het lyrisch ik zichzelf ervaart als een uit geometrische vormen opgebouwde compositie à la De Chirico.

Een laat voorbeeld van het verlangen naar opheffing van de dualiteit is 'Wiederauf-führung Sternenstunde' ${ }^{69}$, waarin net als in het hierboven besproken gedicht 'Eenvoudig' de woorden 'vanzelfsprekend' en 'eenvoudig' opvallen, als uitdrukking van de directheid van de pre-reflexieve ervaring. Ook hier vloeien in het woord 'eenvoudig' allerlei betekenissen samen: gemakkelijk/moeiteloos én niet-samengesteld/non-dualistisch:

Ademen als ooit alsof

lichaam en geest vanzelfsprekend

68 in: Proefruin. Den Haag 1953: 11

69 in: Kaalslag. Amstendam 1999: 54 
zijn en eenvoudig

bijeen $[\ldots]$

Hoewel het verlangen naar opheffing van de dualiteit vaak op een echec uitloopt, zijn er toch situaties waarin dat verlangen gerealiseerd wordt. Eén daarvan is de liefdevolle sexualiteit, zoals die bijvoorbeeld wordt opgeroepen in het gedicht 'Vereenvoudigd'. ${ }^{70}$ De woorden 'vereenvoudigd' en 'automatisch' (in de betekenis van 'buiten het denken om') werken hier als signaal voor de directheid van de pre-reflexieve ervaring:

\section{VEREENVOUDIGD}

Vereenvoudigd tot huid en haar

tot huid

tot ogen die alleen nog maar

licht vangen van binnen uit

5. tot handen zo vervuld van liefde dat

ze automatisch strelen wat

hen raakt

de adem binding tussen dag en nacht

het lichaam tot zichzelf teruggebracht

10. en vervolmaakt.

Een laatste voorbeeld is het gedicht 'Zoals' "7' , warin de pre-reflexieve beleving van het lichaam als 'Leib' vergeleken wordt met de vanzelfsprekende lichamelijkheid van een dier. Signalen die deze beleving aangeven zijn, naast de vergelijkingen met kat en vogel, de woorden 'probleemloos' (r.7) en 'zorgeloos' (r.13):

\section{ZOALS}

Zoals jij ligt zo los

kan hoogstens een kat liggen of

een ander dier maar zelden

zelden een mens

70 in: Het stmisngelnesenuat. Amstendam 1963:27

71 in: De huid als natkvlak. Amsterdam 1964: 12 
5. zo rondom zichzelf zijn kan hoogstens

een vogel of een andere gevleugelde

die zichzelf probleemloos opheft

en meeneemt. naar elders niet beter

maar anders

10. zo zonder stem en toch helder

communicerend zo moeiteloos

het hart als kleine motor laten draaien

zo zorgeloos het bloed

zijn gang laten gaan

kan alleen jij.

Warmonds lichaamsvisie sluit aan bij de herwaardering van het lichaam, waarvan na de Tweede Wereldoorlog sprake is en die bijvoorbeeld ook in de poézie van de Vijftigers is terug te vinden. Hierbij gat het uitdrukkelijk niet om een ontkenning van de geest, maar om een uitbreiding van een te smal geworden humanisme, aldus Hugo Brems in zijn studie Lichamelijkheid in de experimentele poëzie. ${ }^{72}$ Een eenzijdig accent op de geest wordt genuanceerd door een herwaardering van de niet-rationele vermogens van de mens: irrationaliteit, mysterie, symboliek en oorspronkelijke zuiverheid. Deze aspecten spelen ook een belangrijke rol in de Cobra-kunst, samen met een fascinatie voor de spontaniteit van de kindertekening en volkskunst uit allerlei culturen. De belangstelling voor magische symbolen blijkt bijvoorbeeld uit het feit, dat de Babylonische voorstelling van het hemelsymbool, een tot een spiraal opgerolde slang, in 1950 in allerlei Cobra-uitgaven als een kenteken van de beweging verschijnt. ${ }^{73}$ Vanuit deze beweging klinken bezwaren op tegen het idee van een geïsoleerde, van lichaam en materie gescheiden geest. De Deense Cobra-schilder Asger Jorn acht het onmogelijk dat men zich kan uitdrukken via een 'automatisme psychique pur', een van de kernbegrippen in het surrealistisch manifest uit 1924 van André Breton, want

'Het zich uitdrukken is een physieke handeling die het denken materialiseert. Een psychisch automatisme is dus organisch verbonden aan het physieke automatisme.74

Het uitdrukken van het zuivere denken, dat wil zeggen de metafysische wereld op zichzelf, zoals de surrealisten willen, is volgens Jorn ten enenmale onmogelijk. De metafysische wereld kan niet zonder materiële wereld bestaan, want vanuit zijn

72 Hugo Brems, Lichamelijkheid in de experimentele poezzie. Bijdrage tot de karakterisering en de literair-historische situering van de moderne Nederlandse poezzie 1950-1960. Hasselt 1976:113.

73 zie: Willemijn Stokvis, Cobra. Geschiedenis, voorspel en betekenis van een beurging in de kunst van na de nueede werldoorlog. Amsteriam 1985:99

74 ibid: 84 
materialistische optiek brengt de laatste de eerst genoemde voort. In plaats van psychisch automatisme ziet hij liever experiment en spontaniteit. Jorn geeft de volgende definitie van het streven van de Cobra-experimentelen:

'Notre expérimentation cherche à laisser s'exprimer la pensée spontanément, hors de tout contrôle exercé par la raison. Par le moyen de cette spontanéité irrationelle, nous atteignons la source vitale de l'être. Notre but est d'échapper au règne de la raison, qui n'a été, qui n'est encore autre chose que le règne idéalisé de la bourgoisie, pour aboutir au règne de la vie. ${ }^{75}$

Het lichamelijk bestaan bezit een autonome waarde en heeft geen hogere rechtvaardiging nodig. De levensbron, 'la source vitale de l'être', is bereikbaar in het hier en nu door middel van de spontane beleving. Een soortgelijke teneur is te vinden in het al eerder besproken gedicht 'Bidstonde', waarin een verticale gerichtheid op god wordt vervangen door een horizontale gerichtheid op de mens en met name de geliefde. Aandacht voor de lichamelijkheid betekent bij Warmond niet dat ze zichzelf of de ander reduceert tot louter lichaam. Het betekent integendeel een verruiming, die het haar mogelijk maakt los te breken uit een inperkende rationaliteit. In het gedicht 'Achter glas' verlangt het lyrisch subject naar de directheid van de pre-reflexieve beleving ('de oerwoudangsten van het bloed' en '4 heidense ogen'), zonder ingeperkt te worden door allerlei vanuit het christendom opgelegde normen en waarden:

ik wil de oerwoudangsten van het bloed

onder ogen zien

4 heidense ogen ${ }^{76}$

In 'Ongeletterd' ziet het lyrisch subject ontsnapping aan een controlerende rationaliteit als voorwaarde voor een spontane, dat wil zeggen pre-reflexieve lichaamsbeleving:

Laten wij wijs zijn laten

we nu en dan het verstand verliezen

want het bloed gaat langs ongenummerde wegen

en het hart is niet eetbaar dan voor op de tong

voor ongeletterde tanden ${ }^{77}$

Bovenstaand fragment bevat een opeenstapeling van signalen die de directheid van de beleving aangeven: 'het verstand verliezen', 'ongenummerde wegen', 'het hart is

75 ibid: $84-85$

76 in: Werszij un een wereld. Den Haag 1957: 50

77 in: Wirmte, een uvonplaats. Amsterdam 1961:16 
niet eetbaar dan voor op de tong' en 'ongeletterde tanden'. De regel 'het hart is niet eetbaar dan voor op de tong' bevat een allusie op het gezegde 'zijn hart ligt hem op de tong', een uitdrukking die verwijst naar een spontaniteit waarin denken en voelen vrijelijk samengaan. De woordgroep 'ongeletterde tanden' doet vermoeden dat die directe ervaring niet te combineren is met taal, zij is pre-verbaal. Warmond lijkt te suggereren dat opheffing van het reflecterende subject -ook al is dat misschien tijdelijk- wél mogelijk is door de controlerende rationaliteit uit te schakelen. Dit idee sluit aan bij de fenomenologie van Merleau-Ponty, waarin de door het tweedegraads bewustzijn veroorzaakte breuk tussen subject en wereld hersteld wordt in de pre-reflexieve ervaring. Dit komt ook dicht in de buurt van boeddhistische idecèn, waarin het ego door bepaalde methoden getranscendeerd kan worden en een non-dualistische beleving van het zijn mogelijk wordt geacht. Ik kom hier in hoofdstuk XI op terug.

In de lichaamsopvatting van na de Tweede Wereldoorlog speelt de zintuiglijkheid een. grote rol. Door synesthetische beelden als 'hoor en zie met uw huid' worden het kennen, begrijpen en waarnemen van de wereld als een lichamelijke aangelegenheid voorgesteld. Met name huid en hand worden ervaren als kennisorganen, waardoor het lichamelijk, niet-rationeel, belevend in-de-wereld-zijn een sterker accent krijgt dan in de periode vóór de Tweede Wereldoorlog. ${ }^{78} \mathrm{Bij}$ Warmond zijn 'hand' en 'huid' niet alleen kennisorganen, maar ook communicatiemiddelen bij uitstek, zoals onder andere blijkt uit de titel van de bundel De huid als raakvlak (1964) en uit het volgende fragment uit het gedicht 'Lezen en schrijven':

\section{Schrijf ik hier met vingertoppen \\ die bijna pijn doen van ontroering een elegie op je huid of stond het er geschreven en lezen mijn handen je brailleschrift? ${ }^{79}$}

De beleving in dit fragment is duidelijk synesthetisch: in de passage 'lezen / mijn handen je brailleschrift' worden tastzin en zien met elkaar gecombineerd en vermengd. De synesthesie, een stijlmiddel dat geliefd is bij symbolisten, Tachtigers én Vijftigers, staat in verband met het herontdekken van het voor-wetenschappelijk, belevend kennen. $\mathrm{Zij}$ speelt een fundamentele rol in het herscheppen van de oorspronkelijke eenheid tussen mens en wereld, een aspect dat met name in de fenomenologie een belangrijke rol speelt.

In mijn bespreking van diverse gedichten vạ Warmond kwam al naar voren dat de directe, pre-reflexieve eenheidservaring onder andere mogelijk is in de sexualiteit. Een dualistische beleving maakt dan plaats voor een unificerende werkelijkheidservaring, waarin het lichaam als 'Leib' en niet als 'Körper' ervaren wordt. Volgens

\footnotetext{
78 zie Hugo Brems, Hasselt 1976: 116-120

79 in: Het struiswogelresenvaat. Amstendam 1963:31
} 
Brems is het herscheppen van een paradijselijke eenheidswereld, het mythische verlangen naar een terugkeer naar een paradijselijke oerstaat inherent aan een in wezen romantisch wereldbeeld waarin de strenge scheidingen zijn opgeheven. Net als de symbolistische correspondances en het surrealisme is ook dit een poging om tegenstellingen op te lossen, het is een zoeken naar synthese. Brems wijst op de invloed van het modernisme, dat in de Nederlandse literatuur pas laat is doorge-broken, en op de invloed van het existentialisme. Opmerkelijk genoeg zegt hij niets over de fascinatie van bepaalde dichters, onder wie bijvoorbeeld Bert Schierbeek, voor het (Zen)boeddhisme, waarin het ervaren van non-dualiteit een grote rol speelt. Warmond heeft in interviews aangegeven dat zij geinteresseerd is in boeddhisme en taoïsme, filosofieën waarin ik-loosheid en directheid van ervaring een belangrijke rol spelen en elkaar lijken te impliceren. Ze gebruikt poëtische middelen om de aandacht hierop te richten: een opeenstapeling van infinitiefconstructies waarin het subject afwezig is (zoals in 'Eenvoudig'), synesthesie en beelden voor pre-verbaliteit ('ongeletterde tanden'). Verder gebruikt ze beelden om het loslaten van een beperkende rationaliteit of inperkende normen en waarden op te roepen ('de oerwoudangsten van het bloed' en ' 4 heidense ogen'). De directheid van de pre-reflexieve ervaring of het verlangen daarnaar is herkenbaar aan signaalwoorden als 'vanzelfsprekend', 'eenvoudig' in de zin van 'moeiteloos' én 'non-dualistisch', 'laten' in de betekenis van 'toelaten/niet verhinderen', 'problecmloos', 'zorgeloos', 'natuurlijk', 'onvatbaar', 'terugkeer' en 'oorsprong'.

\section{Conclusie}

In dit hoofdstuk stond de vraag centraal of het zinvol is om poëzie en met name Warmonds poëzie vanuit een literair-existentialistisch perspectief te bestuderen. Het antwoord is bevestigend. Thema's als angst, walging, vervreemding, grenssituaties, personificatie van objecten, gesloten ruimtes en geseculariseerde invulling van christelijke begrippen wijzen op affiniteit met het existentialistische gedachtegoed. Ook de representatie van het lichaam sluit hierbij aan. De beleving van het lichaam als 'Leib' of 'Körper' blijkt samen te hangen met respectievelijk het pre-reflexieve en het reflexieve bewustzijn. De visie van Sartre op de liefde als een spel van overwinnaar en overwonnene is in Warmonds werk niet terug te vinden.

Er zijn enkele opmerkelijke overeenkomsten tussen Paspoort voor niemandsland en Warmonds poëzie. Veel is te herleiden tot het Sartriaanse model, maar ook in Warmonds poëzie blijkt dit model alléén niet te voldoen. Zowel in proza als poëzie heeft Warmond het spanningsveld tussen vervreemding enerzijds en verlangen naar eenheid anderzijds gethematiseerd. Gemeenschappelijk is ook, dat de pre-reflexieve ervaring van eenheid en verzoening mogelijk is in de erotiek. Bovendien geeft het ambiguïteitsmodel van Merleau-Ponty niet alleen Warmonds proza maar ook haar poëzie meer diepgang en reliëf dan het conflictmodel van Sartre. 


\section{DE ABSTRACTE WARMOND}

\section{Inleiding}

In het eerder besproken 'Vereenvoudigde religie" signaleerde ik, dat Warmond in dit gedicht de conventionele lyrische vorm doorbreekt. Er is namelijk sprake van een verhalende situatie met een impliciet externe vertelinstantie. Deze verhalende vorm creëert extra afstand, die functioneel is binnen de depersonalisatiethematiek van 'Vereenvoudigde religie'. Het is echter niet de eerste en zeker ook niet de laatste keer dat Warmond afwijkt van de conventionele lyrische vorm. Het eerste voorbeeld is het gedicht 'Dichter' in haar debuutbundel Proeftuin ${ }^{2}$ :

\section{DICHTER}

Hij speelt met woorden als

een kind met blokken

pakhuizen wanhoop worden ingedeeld

tussen begrippen en hun synoniemen

5. een onbevangen schijnbaar doelloos

spel maar in zijn mond

rijden de speelgoedtreinen eenzaamheid

langs radeloze klankrails in het rond.

In ruim twintig gedichten, verspreid over tien tundels, past Warmond deze hij-vorm toe, met name in de bundels Naar men zegt (1955), De huid als raakvlak (1964) en Kaalslag (1999): respectievelijk vijf, vier en drie keer. Hieruit blijkt dat deze vorm noch incidenteel is noch beperkt blijft tot éen bepaalde bundel of periode. Je zou het een stijlkenmerk van Warmond kunnen noemen. Het is opmerkelijk dat de tegenhanger, namelijk gedichten in de zij-vorm, nauwelijks in het werk van Warmond voorkomen. Ik heb slechts twee voorbeelden kunnen vinden: 'Troost voor psychiaters 2, en 'Goed gesprek'.

Het gebruik van het persoonlijk voornaamwoord 'hij' is niet eenduidig, aangezien het zowel kan verwijzen naar een mannelijk persoon als naar de mens in het algemeen. In het laatste geval wordt het generiek gebruikt: het verwijst naar mannen én vrouwen. Een voorbeeld van dit generieke gebruik is de zin: de mens sport, omdat hij beweging nodig heeft. De taalgebruiker weet, dat 'hij' hier generiek gebruikt is en dus verwijst naar mannen én vrouwen. Toch is dit niet geheel onproblematisch. Zo wordt in de genderlinguïstiek onderzocht of taalgebruikers door het genericke

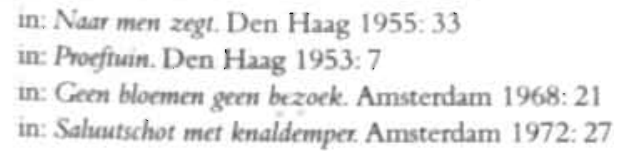


gebruik van mannelijke verwijswoorden vergeten dat het ook over vrouwen gaat. Hoewel er nog te weinig onderzoek naar gedaan is, zijn de resultaten steeds bevestigend. $^{5}$

In tegenstelling tot het mannelijk pronomen heeft het vrouwelijk equivalent minder verwijzingsmogelijkheden, hoewel bepaalde auteurs deze beperking welbewust doorbreken, zoals Andreas Burnier die naar 'dé mens' consequent met 'zij' verwijst. Over het algemeen kan 'hij' in universelere zin gebruikt worden dan 'zij', dat eerder beperkt blijft tot een vrouwelijk individu of tot een bepaald type vrouw. Waarom heeft Warmond voorkeur voor de hij-vorm? Is het, omdat zij daarmee kan abstraheren van individuele personen, inclusief zichzelf, en van een tot een enkel individu beperkte problematiek? Het wemelt in haar werk namelijk van allerlei abstraherende afstand bewarende en afstand scheppende aanduidingen: 'men', 'de mens', 'mensen', 'iemand'. Er zijn niet of nauwelijks genderaanduidingen te vinden in gedichten waarin gesproken wordt van een 'ik', een 'jij' of 'wij'. Deze neutraliteit of dit openlaten wordt hier en daar versterkt door het gebruik van pronomina met ingesloten antecedent (zoals 'wie' en 'die'). Ik. kom hier later op terug.

Het pronomen 'je' verwijst een enkele keer duidelijk naar een geliefde, maar het wordt ook vaak gebruikt in de functie van onpersoonlijk voornaamwoord. Hierdoor lijkt Warmond gedachten en gevoelens te veralgemenen. Nadere analyse wijst echter uit, dat er niet geabstraheerd wordt: 'je' en 'ik' blijken in dat soort gevallen vaak samen te vallen. $l \mathrm{k}$ kende deze vorm -die afstand creëert ten aanzien van zichzelf- in eerste instantie vooral van geinterviewde voetballers, hoewel het gebruik steeds algemener begint te worden. Een voorbeeld van zo'n geabstraheerd 'ik' bij Warmond is 'Ziet/Denkt':

\section{ZIET/DENKT}

Je ziet mensen als wieren

in een moeras

waaruit de verrotting opstijgt

je ziet ogen als gaten

5. in een gezicht

waar de ellende afdruipt

je ziet doden als huurlingen

in het gelid

waar geen doorkomen aan is

5 zie A. Agnes Sneller/A. Verbiest, Wat uvonden doen. Cursusbork genderlinguistick. Bussum 2000:151-152

6 in: Testbeeld wor koud klimaat, Amstendam 1966:41 
10. je denkt: ik ben gek

dat ik schrijf

en je schrijft.

In diverse gedichten komen woordgroepen voor als: de mens(en), de geliefden, de jabidders, de agnosticus, de middenstander. In dit soort gevallen heeft hẹt lidwoord een categoriale functie, waardoor de substantiva een abstracter karakter krijgen. Het gat hierbij niet zozeer om individuen als wel om de hele groep of de duidelijke representant daarvan. Een andere abstraheringstechniek van Warmond is het veelvuldig gebruik van 'men', waardoor de door het gezegde uitgedrukte werking centraal komt te staan en de handelende persoon in het vage wordt gelaten. Voorbeelden van deze twee abstraheringsstrategieën zijn:

De mens - bedroefde blinde

die soms plotseling zien kan maar niet

weet of dat wat hij ziet

bestaat en tastbaar is te vinden -

$[\ldots]^{7}$

Wat men aanvankelijk begeert:

een levend beeld door eigen handen geboetseerd,

een talisman van warmte,

gemakshalve liefde genaamd.

$[\ldots]^{8}$

Het is aannemelijk dat Warmond zichzelf dẹ uit vindt maken van de categorieèn die met 'men' of 'de mens' aangeduid' worden. Geeft zij hiermee aan dat bepaalde gevoelens / ervaringen niet particulier maar universeel zijn of wordt hier een versluie-ringstactiek gebruikt om de aandacht van zichzelf af te leiden? Misschien kunnen de zogenaamde hij-gedichten hierop een antwoord geven. Deze groep valt thematisch uiteen in twee categorieën. De eerste categorie bevat gedichten die kritiek op een bepaald mannelijkheidsideaal bevatten, terwijl in de tweede categorie desillusie de boventoon voert.

\section{Mannelijkheidskritiek}

Van de categorie hij-gedichten die kritiek bevatten op een bepaald mannelijkheidsideaal is het gedicht 'Chanson prèsque triste ${ }^{.9}$ een goed voorbeeld. De eerste

7 uit: 'Kleine antropologie'. In: Warmte, cen woonplaats, Amstendam 1961: 45

8 uit: 'Pygmalion'. In: Warmte, cen woonplaats, Amsterdam 1961:47

9 in: Naar men zegt. Den Hagg 1955: 31 
strofe bevat een opeenstapeling van allerlei mannelijkheidsattributen, die de kracht, vitaliteit en glamour van filmsterren uit Hollywood oproepen:

Hij beloofde zijn toekomst een spierdier een technicolorpotentie

een bicepsbeeld.

Het gedicht roept het mannelijkheidsideaal van de succesvolle bodybuilder op: zó had 'hij' willen zijn. Maar wat is er uiteindelijk van hem terechtgekomen:

een wirwartol verdwaald

in mierennesten haastige verwarring

voor honderden ogen een 1-oog.

In de laatste strofe spelen twee allusies door elkaar heen: 'in het land der blinden is eenoog koning' en 'alle ogen zijn op hem gericht'. Hierdoor ontstaat er een interessante ambiguiteit. In de eerste strofe valt de term 'technicolorpotentie' op, een term die suggereert dat het lyrisch subject net zo beroemd wilde worden als een filmster of op zijn minst 'gezien' wilde worden. In plaats van honderden ogen -de ogen van het bewonderende publiek - is er nog maar een enkel oog op hem gericht: hij wordt en is nauwelijks gezien. Tegelijkertijd roept de laatste regel de uitdrukking 'in het land der blinden is eenoog koning' wakker. Het lyrisch subject weet dat hij mislukt is, maar niet iedereen heeft. dit door: voor veel mensen -'honderden ogen'- lijkt hij nog heel wat. Of is het zo, dat alleen de externe vertelinstantie zijn mislukking doorheeft, in tegenstelling tot vele ook in hun leven mislukte anderen ("honderden ogen')? Gaat dit gedicht over het type man dat zich voor het oog van de buitenwereld weet voor te doen als een belangrijk mens door zich op te pompen met nietszeggende pretenties, waar een intelligent mens als Warmond zo doorheen kijkt? Hoe dan ook, ideaalbeeld en realiteit zijn elkaars tegenbeeld; samen vormen ze een dubbelportret van dit type man.

Een ander kritisch voorbeeld is het gedicht 'Carrière $\mathrm{I}^{10}$, dat een soortgelijke opbouw heeft als 'Chanson prèsque triste'. De eerste strofe roept op wat het lyrisch subject graag had willen doen:

Hij die zo graag een vlam had willen schrijven

een goed houdbare papieren

om uit te knippen te verzenden

als circulaire

(alle brievenbussen zijn gelijk)

10 in: De haid ats nakblak, Amstendam 1964:30 
terwijl de tweede strofe de realiteit toont:

hij beschreef een kartonnen valbijl

gereserveerd voor eigen gebruik

boven de sluipgaten tussen

grootspraak en breedspraak

Hier wordt het beeld opgeroepen van iemand die van plan was op vurige wijze hartstochtelijke stukken te schrijven waar hij anderen mee in vuur en vlam had willen zetten. In plaats, daarvan 'beschreef [hij] een kartonnen valbijl'. Wat is er krachtelozer en ineffectiever dan een kartonnen guillotine? Opmerkelijk is het verschil tussen 'schrijven' (r. 1) en 'beschreef' (r. 6). 'Beschrijven' is weergeven wat je ziet of hebt gezien. Het mist de scheppende kracht die eigen is aan 'schrijven'. Op deze wijze geeft Warmond subtiel aan, dat de 'hij' niet in staat is iets eigens te creëren. Hij blijft hangen in 'grootspraak en breedspraak'. Het laatste woord is een doeltreffend neologisme, waar 'breedsprakig' en 'woordenbrij' in doorklinken. De 'hij' is blijkbaar ook niet in staat tot efficiënt en effectief taalgebruik. Tegelijkertijd roepen 'grootspraak en breedspraak' het beeld op van een opschepperige ijdeltuit. Warmond lijkt in dit gedicht de mislukte schrijver te portretteren.

Een derde en laatste voorbeeld is het gedicht "Alles is ijdelheid I / $\mathrm{II}^{11}$. Het gedicht ademt de sfeer van het oud-testamentische wijsheidsboek Prediker. De titel verwijst naar het eerste hoofdstuk daaruit: TJl en ijdel, zegt Prediker, ijl en ijdel, alles is ijdel. Wat heeft de mens aan al zijn zwoegen en tobben onder de zon? ${ }^{12}$ Ook in dit gedicht is er een impliciet externe vertelinstantie die kritiek levert op de levenshouding van het lyrisch subject:

Hij tooit zich hijgend

met zijn drijfveer

hij moet weer

verder of hogerop

$[\ldots]$

gegeseld door eigen streven

staat hij zich naar het leven

11 in: Vragen stellen aan de stilte, Amsterdam 1984:29-30

12 in: Predilec I: 2-3. Willibrordvertaling. Boxtel/Brugge 1977: 844 
hij komt. er hij komt er heus.

Dat was het dan. ${ }^{13}$

De impliciet externe vertelinstantie levert hier kritiek op een westers mannelijkheidsideaal: de harde, ambitieuze werker die desnoods ten koste van zichzelf carrière wil maken. 'Alles is ijdelheid II' is qua stijl enigszins te vergelijken met die van Prediker. Evenals het bijbelboek bevat dit gedicht een aantal maximes waarin de levensvisie van de auteur beknopt is weergegeven:
Alle grote woorden
eindigen in een hoestbui
eens laat zelfs de spiegel
het afweten zeker
is dat de zekerheden
waaraan hij smeedde (noest
of niet) zijn bocien worden
en ten slotte: roest ${ }^{14}$

Eerder zei ik, dat de twee bovenstaande gedichten de sfeer ademen van Prediker. Dit is echter slechts ten dele het geval. Prediker bevat een soort nabeschouwing van iemand die het leven en de wereld grondig onderzocht heeft en tot de conclusie komt dat alles ijdel' is. Maar het boek bevat ook nog een andere-vrolijke- teneur die ik niet in deze twee gedichten tegenkom: 'Maar iets goeds heb ik toch ontdekt. Wat deugd doet is eten en drinken en van het goede genieten bij alle zwoegen en tobben onder de zon $[\ldots]^{15}$ en 'Hoe lang iemand ook leeft, laat hij genieten van elke dag en bedenken dạt ẹ nog donkere dagen genoeg zullen zijn en dat alles wat daarna komt ijdel is. " ${ }^{16}$ Het accent ligt bij Warmond op kritiek van de leegheid van een dergelijk bestaan.

In deze paragraaf besprak ik een. aantal zogenaamde hij-gedichten waarin Warmond het contrast laat zien tussen mannelijkheidsideaal en werkelijkheid. In het ene geval blijkt het lyrisch subject zijn ideaal om een filmachtige glamourboy te worden niet te kunnen realiseren ('Chanson prèsque triste'), in het andere geval. verzandt de man die van plan was een groot schrijver te worden in 'grootspraak en breedspraak' ('Carrière I'). In 'Alles is ijdelheid I / II' levert Warmond kritiek op' een bepaald mannelijkheidsideaal: de harde, ambitieuze carrièremaker. Door de hij-vorm te kiezen creëert ze afstand van het type man dat niet in staat is tot een zuivere, realistische kijk op zichzelf en van het type man dat zich niet richt op de

\footnotetext{
13 'Alles is ijdelheid I'. In: Vragen stellen aan de stilte, Amstendam 1984: 29

14 in: Vnapen stellen aan de stilte, Amsterdam 1984: 30

15 in: Prediker V: 17

16 ibidem XI: 8
} 
essentialia, ook al noemt ze niet expliciet welke dat dan zijn, maar uit de context blijkt dat het nastreven van een carrière ten koste van zichzelf daar in ieder geval niet onder valt. Ze kijkt dwars door al die opgeblazenheid heen.

\section{Desillusie}

In de tweede categorie hij-gedichten is iets anders aan de hand. In deze-groteregroep gedichten attaqueert Warmond niet een bepaald mannelijkheidsideaal, maar roept zij een sfeer op van desillusie, eenzaamheid, depersonalisatie en existentiële crisis. Een duidelijk voorbeeld daarvan is het door mij eerder besproken gedicht 'Vereenvoudigde religie'. Het gedicht ' 1 - de anderen $=2{ }^{17}$ gaat nog een stapje verder. De 'hij' heeft zich in twee partijen gesplitst: degene die handelt en degene die gadeslaat. Beide partijen zijn aan elkaar gewaagd, want 'ze vochten / en sliepen samen':

Hij kon tevreden zijn

hij had zichzelf verdeeld

in twee partijen handelen

en gadeslaan ze vochten

5. en sliepen samen als twee

die aan elkaar gewaagd zijn

ze konden allebei tevreden zijn

buiten elkaar onderhielden

ze geen relaties

10. hun enige zorg was nog

de ander kwijt te raken.

De 'hij' plaatst tegenover het gadeslaan het handelen ofwel: een daad verrichten, niet blijven toezien. Hij kan niet kiezen tussen meedoen en erbuiten blijven. Wáár hij aan mee wil doen of wáár hij buiten wil blijven, is iets wat Warmond openlaat. Het heeft geen zin om op deze plaats nog meer voorbeelden te bespreken, omdat de bedoelde gedichten -op enige nuanceverschillen na- thematisch gezien op hetzelfde neerkomen. In de eerste categorie gedichten koos Warmond de hij-vorm om afstand te creëren ten aanzien van een bepaald mannelijkheidsideaal. In de tweede categorie veroorzaakt de hij-vorm ook afstand, maar waarvan? Wil Warmond op die manier afstand nemen van een door desillusie bepaalde levenshouding of wil ze die houding in een algemener kader plaatsen om te abstraheren van anders te particulier te interpreteren gevoelens? Of is er nog iets anders aan de hand? Is er in deze categorie gedichten misschien (ook) sprake van een ik-maske-

17 in: Naar men zegt. Den Haag 1955: 34 
rade, met andere woorden wil Warmond door middel van de hij-vorm de aandacht van zichzelf afleiden?

De eerste hypothese is niet aannemelijk, aangezien desillusie, eenzaamheid, deperso-nalisatie en existentiële crisis ook voorkomen in een aantal ik-gedichten, hoewel die minder vaak voorkomen dan de tweede categorie hij-gedichten. In 'Niets dan dit' 18 bijvoorbeeld maakt het lyrisch ik gedesillusioneerd -of moet ik zeggen realistisch, in de zin van: de illusies van zich afgeschud?- de balans op:

\author{
Wat schreef ik gister \\ dat nog tastbaar is \\ wat leefde ik gister \\ dat nog bestaat?
}

niets

Andere voorbeelden zijn 'Woonhuis I'19 (depersonalisatie: 'een overdwars gespleten kegel draag / ik tussen schouders die me vreemd voorkomen'), 'Schipbreuk'20 (existentiële crisis: 'Ik wilde me inschepen voor / een land waar ik nog niet bestond // onderweg ben ik verdronken'), 'Status ${ }^{21}$ (desillusie: 'Vraag je af wat het er toe doet / en je voelt je een weeshuis worden / zo zinloos vol en zo geiisoleerd / (...)// en het gelijk / waarmee ik het weerleg / valt buiten bereik / vloeit weg') en 'Persoonsbewijs voor inwoner' 22 (vervreemding: 'Hoe men zichzelf kan bewonen / als een nooit volkomen aanvaarde / nooit volmaakt gewende / vreemdeling'). In een aantal gedichten maakt Warmond gebruik van nautische en maritieme metaforen om de wanhoop en de eenzaamheid van het lyrisch subject op te roepen, zoals in 'Amok'23:

De kamer is op vier hoeken

door de wanhoop aangevaren

$[\ldots]$

de reddingboten van

mijn ogen drijven stuurloos

door de poolzee van hun eigen kilte

door een zinverloren leegte

in een godverlaten stilte.

18 in: Werszij yne cen wereld, Den Hag 1957: 25

19 in: Proffuin, Den Haag 1953:11

20 ibidem: 31

21 in: Testbeeld noor koud klimat, Amstendam 1966: 24

22 in: Vhapen stellen aan de stilte, Amsterdam 1984: 27

23 in: Proeftuin, Den Haag 1953: 30 
Door deze voorbeelden is ook de derde hypothese ontkracht. De hij-vorm dient er niet toe om de aandacht van zichzelf af te leiden, aangezien een soortgelijke thematiek als in de tweede categorie hij-gedichten ook in een aantal ik-gedichten voorkomt. Er is dus geen sprake van een ik-maskerade.

Blijt over de tweede hypothese: de hij-vorm wordt gebruikt om gevoelens in een algemener kader te plaatsen. Hierdoor kan er geabstraheerd worden van een anders te particulier te interpreteren context. De hij-vorm kan immers op mannen én vrouwen slaan, in tegenstelling tot de zij-vorm, die deze generaliserende kracht niet heeft. De in deze gedichten opgeroepen gevoelens zijn niet specifiek mannelijk of vrouwelijk, maar algemeen menselijk. Het is mogelijk, dat Warmond hiermee niet alleen wil abstraheren van een specifiek persoon (bijvoorbeeld zichzelf), maar ook van gender of sekse.

In bepaalde gevallen kan de keuze voor de hij-vorm stilistisch gemotiveerd zijn. Uit onderstaande omzettingsproef van het gedicht 'Vereenvoudigde religie ${ }^{24}$ blijkt, dat de hij-vorm hier een grotere dramatische kracht heeft. Ze is wat mij betreft daardoor overtuigender. De ik-vorm werkt hier niet, omdat de blik te taxerend of te evaluerend is voor een 'ik'. Bovendien is de inhoud te confronterend. Net zoals een schilder een paar passen achteruitgaat om zijn werk beter te kunnen beoordelen, zo creëert de dichter afstand en overzicht door in plaats van de ik-vorm de afstandelijker hij-vorm te gebruiken:

Hij vergiste zich telkens opnieuw op dezelfde hoopvolle wijze maar toen de god met de glimlach verhongerd was bouwde hij in de spiegel een antigod en leerde zichzelf te haten zoals men een voorwerp haat

zo won hij dagelijks afstand tot hij ten slotte zijn lichaạm onteigend had en het 's avonds tussen zijn lakens schoof als een zakelijk toegevouwen brief in een enveloppe.
Ik vergiste me telkens opnieuw op dezelfde hoopvolle wijze maar toen de god met de glimlach verhongerd was bouwde ik in de spiegel een antigod en leerde mezelf te haten zoals men een voorwerp haat

zo won ik dagelijks afstand tot ik ten șlotte mijn lichaạm onteigend had en het 's avonds tussen mijn lakens schoof als een zakelijk toegevouwen brief in een enveloppe.

\section{Andere abstraheringstechnieken}

In de inleiding besprak ik al enkele andere abstraheringsstrategieën in het werk van Warmond: het veelvuldig gebruik van 'mensen', 'iemand', pronomina met 
ingesloten antecedent en het gebruik van 'je' in de functie van onpersoonlijk voornaamwoord. Vervolgens wees ik op substantiefgroepen met een lidwoord met categoriale functie, zoals 'de mens', 'de agnosticus' en 'de geliefden', waardoor niet een individuele persoonlijkheid maar een groep of de representant daarvan centraal komt te staan. Een soortgelijk effect heeft het -veelvuldig- gebruik van 'men', waardoor de handelende persoon in het vage wordt gelaten.

Opmerkelijk is een categorie gedichten waarin geabstraheerd wordt van tijd én van persoon door elliptische constructies waarin de persoonsvorm weggelaten is. Het werkwoordelijk gezegde is in deze gevallen gereduceerd tot een voltooid deelwoord of infinitief. Het effect daarvan is verschillend. Ik zal dit demonstreren aan de hand van de gedichten 'Zo moet het' ${ }^{25}$ en 'Herkansing I' 26 .

\title{
ZO MOET HET
}

\author{
Alles gevonden \\ gemeten geweten \\ daarna alles verloren \\ en eindelijk horen \\ de stilte zingt.
}

5. dit is het:

De tot voltooid deelwoord gereduceerde werkwoordsgroep (r. 1-3) abstraheert van tijd en persoon: de lezer weet niet of het impliciet gebleven lyrisch subject een 'ik' of een 'hij'/zij' is. Bovendien kan hij hier zowel een voltooid tegenwoordige tijd ('heb alles gevonden') als een voltooid verleden rijd ('had alles gevonden') invullen. De voltooid verleden tijd wordt vaak gebruikt om aan te geven dat het ene gebeuren plaatsvond vóór het andere, terwijl de voltooid tegenwoordige tijd onder andere geschikt is voor verslaglegging van gebeurtenissen waarin feiten en resultaten genoemd worden. Beide vormen geven aan dat er een balans wordt opgemaakt. Het resultaat staat in het presens, dat hier een algemene waarheid meedeelt die onafhankelijk is van de tijd:

en eindelijk horen

dit is het:

de stilte zingt.

De tot infinitief gereduceerde werkwoordsgroep heeft een ander effect:

25 in: Gesloten spicgels. Amsterdam 1979: 16

26 in: Vhagen stellen aan de stilte. Amsterdam 1984:9 


\section{HERKANSING I}

Bouwen aan een uitzicht voor gesloten ogen

kijken wel maar nog geen vragen stellen

luisteren wel maar nog niets kunnen horen

roerloos wachten op de schreeuw

wie wordt geboren?

[...]

alles zeer stil

het woord is aan

de etsnaald / het moment.

Ook hier wordt geabstraheerd van tijd en persoon: het lyrisch subject blijft impliciet, en het is ook niet duidelijk of het 'bouwen' nu of in de toekomst plaatsvindt. Bovendien wordt er geabstraheerd van modaliteit: is het een kwestie van moeten, kunnen, willen, gaan, zullen? Dat is niet duidelijk. De infinitiefvorm heeft een programmatisch effect. Hij geeft als het ware programmapunten aan: dit moet ik doen of dit neem ik mij voor om te doen. Het resultaat van dit alles staat te lezen in de laatste strofe. De presensvorm die hier gebruikt wordt, focust de lezer op een soort tijdloos nu.

Warmond gebruikt abstraheringstechnieken dus ook om een inventariserend en programmatisch effect te bewerkstelligen.

\section{Onthullende verhulling}

In vergelijking met veel andere dichters kent het werk van Warmond opvallend veel verzen waarin een 'ik', 'jij' of 'wij' voorkomt zonder dat het voor de lezer duidelijk is of hier sprake is van mannen of vrouwen. Deze gedichten zijn sekse-neutraal, iets wat bijvoorbeeld ook het werk van Ida Gerhardt kenmerkt. Dit is intrigerend en roept een aantal vragen op. Wat is de achtergrond van deze neutraliteit? Is het een versluieringstechniek om Warmonds homoseksualiteit te maskeren of geeft Warmond hiermee aan dat ze sekse-onderscheid niet relevant vindt? Met andere woorden: wat onthult deze verhulling?

In haar boek. De lust tot lezen wijst Maaike Meijer op een aantal verhullings- en onthullingsstrategieën als signaal van het lesbische. ${ }^{27} \mathrm{Zij}$ noemt de volgende strategieën: schrijven in sapphische strofen, verwijzingen naar Sappho als persoon en naar Sappho's werk, narratieve distantie en streven naar het universele als sekse-neutrale

27 zie boofdstuk 8 'Lezen als lesbo'. In: De lust tot lezen. Nederlandse didteressen en het literaire systecen, Amsterdam 1988: 240-284 
strategie, waar met name Gerhardt en Warmond voor gekozen hebben. Meijer wijst terecht op het maatschappelijk taboe op homoseksualteit in met name de jaren '50:

Die consequent volgehouden neutraliteit stelde hen in staat te publiceren en als dichters gerespecteerd te worden, terwijl ze tegelijk een wereld schiepen buiten de traditionele gender-indelingen om. ${ }^{28}$

Die sekse-neutraliteit is voor mij niet alleen een signaal, maar ook een vorm die mij als lezer een grote mate van vrijheid geeft, waardoor de inhoud een stuk spannender kan worden. Die neutrale formulering laat allerlei combinaties toe: $\mathrm{man} / \mathrm{vrouw}, \mathrm{man} / \mathrm{man}$ of vrouw/vrouw.

Volgens Meijer schreef Warmond slechts één speels-erotisch vers waarin de damesliefde een rol speelt:

\section{IN TENMINSTE TWEE MENSEN EEN WELBEHAGEN ${ }^{29}$}

Je seint niet in code

je seint niet je ligt

je bestaat en dat volstaat

je rijmt op jezelf als een ode

5. een goed ouderwets gedicht

met een vrouwelijk liggend ritme

(of metrum, in elk geval

vrouwelijk liggend) een huid ...

(niet zo halsoverkop!) een versvoet

10. van vrouwelijk liggend

kortom

ik bedoel te zeggen

niet meer en niet minder

dan vrouwelijk liggend

15. dan:

vrouwelijk.

liggend.

28 in: De hust tot lezen, Amsterdam 1988: 277

29 in: De groeten aan andersdenkenden, Amsterdam 1970: 24 
Hoewel de voorbeelden dun gezaaid zijn, is Warmond nou ook weer niet zo karig geweest. De ondertitel van 'Vertroosting aan een joffer ${ }^{30}$ geeft duidelijk aan dat dit gedicht over de damesliefde gaat: 'Bij het vertrek ener andere'. Bovendien bevat het verwijzingen naar Sappho en Lesbos. 'De goddelijke divan' ${ }^{31}$ ten slotte bevat voor de goede verstaander duidelijke aanwijzingen:

Zo niet geboren dan toch wel getogen met de overtuiging de rok is nader dan de broek

is het eenvoudigste

5. zich daarbij neer te leggen letterlijk en figuurlijk goedkoop op de eigen divan very relaxed very relaxing

want vond men in de romantiek

10. nog graten in La Belle Dame Sans Merci

things are improving

de mooie dames zijn vandaag de dag

bij lange na niet allemáál zonder genade.

Interessant is, dat dit gedicht een allusie bevat op een bekend romantisch-decadent thema: La Belle Dame Sans Merci, vernoemd naar het gelijkluidende gedicht van Keats, waarin onder andere de volgende regels staan:

I saw pale kings, and princes too,

Pale warriors, death-pale were they all;

Who cry'd - 'La Belle Dame sans merci

Hath thee in thrall!"

5. I saw their starv'd lips in the gloam

With horrid warning gaped wide,

And I awoke, and found me here

On the cold hill side. ${ }^{32}$

La Belle Dame Sans Merci is een representatie van de wrede, diabolisch mooie femme fatale, vol duistere krachten en passies. ${ }^{33}$ In de romantisch-decadente litera-

30 in: De groeten aan andersdenkenden, Amsterdam 1970: 33-34

31 ibidem: 14

32 John Keats, The Poetical Works of John Keats, London 1950: 356

33 ze: Mario Praz, The Romantic Agomy. Oxford 1985: 199 e.v. 
tuur komt zij vooral voor als een mannelijke projectie van ongebreidelde seksuele verlangens. Warmond haalt dit traditionele beeld op geestige wijze onderuit: allereerst door het motief uit het mannelijk domein te halen en ten tweede door het te relativeren:

de mooie dames zijn vandaag de dag

bij lange na niet allemáál zonder genade.

De hypothese, dat sekse-neutraliteit bij Warmond een versluieringstactiek is, blijkt gedeeltelijk juist te zijn. Tot 1970 gebruikt Warmond inderdaad onthullende verhullingsstrategieën, maar de bundel De groeten aan andersdenkenden (1970) is een keerpunt, omdat daarin voor het eerst de versluierende sekse-neutraliteit doorbroken wordt op een manier die aan duidelijkheid niets te wensen overlaat.

\section{Dunne enkels, vederlichte hand}

Een andere hypothese luidt: sekse-neutraliteit geeft aan dat Warmond sekse-onderscheid niet relevant vindt. In een brief d.d. 5 januari 1989 schreef Warmond mij (cursivering van mij):

In je toelichting spreek je aldoor van de aangesproken persoon in de gedichten als 'zij'. Ik weet niet of dat juist is. Ik vind het ook onjuist als in kritieken altijd automatisch van 'hij' gesproken wordt, tenvijl geen van beide preciseringen door mij expliciet gebruikt zijn. Niet omdat ik er bezwaar tegen heb dat men bij het lezen aan het éen of het ánder zou denken, maar je spreekt over de auteur als 'Poëtisch subject'. Bestaat er geen wetenschappelijke tegenhanger voor, het 'poëtisch object' b.v.?

Ik ben me ervan bewust dat dit citaat niet eenduidig is. Warmond geeft namelijk niet aan waaróm ze geen van beide preciseringen niet expliciet gebruikt. Is het bedoeld als verhullingsstrategie of omdat ze het onderscheid niet relevant vindt? Vanwege een aantal uitspraken in interviews en artikelen lijkt het me interessant om ook deze laatste mogelijkheid nader te onderzoeken.

In een gesprek vroeg ik Warmond naar haar reactie op enkele elkaar tegensprekende kritieken waarin haar werk enerzijds werd gekarakteriseerd als 'typisch vrouwelijk' en anderzijds als 'typisch mannelijk'. Uit het antwoord blijkt dat ze beide termen niet werkbaar vindt:

[...] typisch vrouwelijk moeten mensen mij eens uitleggen wat dat is. Dat zou ik graag willen weten. 
Verwijzend naar de uitspraak dat haar werk typisch mannelijk is, omdat het vrij abstract is:

[...]Typisch mannelijk bestaat voor mij niet in die zin. Ik bedoel er bestaan goede en slechte gedichten en wie ze geschreven heeft dat zal me eigenlijk een zorg zijn. [...] De categorie vrouwelijk wordt dus al naar het uitkomt positief of negatief gewaardeerd. [...] daarom geloof ik dat het een cliché is om dat in een kritiek te stellen, niet omdat mensen dat werkelijk interesseert. Hij kijkt op het boekje en hij ziet oh het is van een vrouw dan moeten we even zeggen of het al dan niet vrouwelijk is maar het duidt alleen op de domheid van de criticus. Verder vind ik dat ook van geen enkele importantie.

Ook uit andere interviews blijkt, dat Warmond het onzin vindt om een dergelijk onderscheid te maken, vooral in de kunst. Deze visie wordt ook gedeeld door Rogi Wieg, dichter en enige tijd poëziecriticus voor de Volkskrant. In een recensie ${ }^{34}$ van Vluchtstroken van de taal (1988) schrijft hij naar aanleiding van de dichtregels:

Niet vragen hoe angst precies heet

maar het eigen ik net zo lang

recht in de ogen zien

tot het een weerwoord weet

het volgende:

Deze houding spreekt mij erg aan, bovendien is de formulering krachtig. Maar of zo'n houding typisch vrouwelijk is? Juist omdat poëzie een verfijnde zaak is wordt in goede gedichten de tegenstelling mannelijk-vrouwelijk opgeheven. Over vrouwelijkheid praat je aan de borreltafel, maar je gaat er niet naar op zoek in het werk van een kunstenares. En dat wordt in de gedichten van Ellen Warmond helaas wel gedaan.

Met die laatste zin bedoelt Wieg, dat er critici zijn die in het werk van Warmond op zoek zijn naar vrouwelijkheid. Wieg snijdt hier een belangrijk punt aan. In het werk van mannelijke dichters. wordt zelden of nooit gezocht naar het typisch mannelijke, men gaat er nog te vaak vanzelfsprekend van uit dat hun werk dit sekse-onderscheid overstijgt en dus universele dimensies heeft. In een column in Het Parool van 20 juli 1965. reageert Warmond op geestige wijze op een aantal kritieken die in de loop der tijd over haar werk verschenen zijn. In de eerste zin van onderstaand citaat zorgt de stijlfiguur van de herhaling voor een ironisch effect:

34 Rogi Wieg, 'Ieder mens is zijn eigen centrum.' de Vollesknant, 7-10-1988 
Een stukje in Elsevier smeet met een grote kop in een grote letter over de grote pagina van dit grote blad: GEEN VROUWELIJK GEVOEL.' Pats!! Daar zit je dan ... Bovendien vraag ik me af wat mannen denken dat dat is: vrouwelijk gevoel. En als het zo'n specifiek vrouwelijk gevoel is, hoe mánnen dan kunnen constateren wie het wel en niet hééft?

In dezelfde column neemt Warmond dichter en poëziecriticus Adriaan Morriën op de hak, overigens zonder zijn naam te noemen. Deze criticus hanteert nogal merkwaardige criteria:

In zijn eerste bespreking merkte hij jaren geleden bekommerd op: 'Een levenswijsheid die een beetje te zwaar lijkt voor de dunne enkels waarop zij gaat'... en over het volgende boekje: 'Voor mij mag ze iets minder knap jongleren met haar in werkelijkheid zo verderlichte hand.' [... i ik hield mijn hart al vast voor de rest van mijn anatomie, die al of niet bijpassend bevonden zou kunnen worden. Toch kan zoiets geloof ik alleen in Nederland. Ik heb tenminste nog nooit in een Franse krant gelezen: 'Ik weiger te geloven in die of die mening van Sartre, want hij loenst ...'

Een enkele keer wordt ook Warmonds vrijmoedig taalgebruik bekritiseerd als zijnde onbeschaafd en onvrouwelijk, zoals indirect blijkt uit het gedicht 'In antwoord op uw schrijven'. ${ }^{35}$ Warmond laat duidelijk blijken dat ze haar taalgebruik niet aan genderbanden laat leggen:

\section{IN ANTWOORD OP UW SCHRIJVEN}

Een inzending voor een jaarboek?

ik weet wel wat leukers vandaag:

in de zon zitten dit bedrijuven

of dat

5. of andere unprintables

warover bezorgde leraren

VHMO

later schrijven zullen: 'het toppunt

van obsceniteit voor een vrouw,

10. (en dan nog in het engels bovendien!)

35 in: Geen bloemen gern bezoek. Amsterdam 1968: 22 
én ik me maar afvragen wat

het toppunt van obsceniteit

dan voor een mán wel zijn zal

misschien de moral standard

15. van een leraar VHMO.

Op geestige wijze deelt ze en passant enkele plaagstootjes uit: r. 3-5 bevat een allusie op "de liefde bedrijven", een bezigheid waarover vrouwen niet geacht worden te schrijven. In bepaalde kringen althans beschouwt men dit als not done. Bovendien strooit Warmond expres nog wat Engelse termen ('unprintables', 'moral standard') door het gedicht als reactie op één van de punten van kritiek. (r. 10). Ze reageert hier vermoedelijk op kritiek die ze op haar gedicht "Slightly drunk" kreeg. ${ }^{36}$ Waarschijnlijk vonden de leraren VHMO in het onderstaande gedicht niet alleen de twee Engelse schuttingwoorden, maar ook de situatie waar de Engelse titel naar verwijst niet passend voor een vrouw:

\section{SLIGHTLY DRUNK}

Waar blijven nu de betere gedachten?

hogerop denk ik op latere leeftijd

(iets in de dertig -oud vond ik dat vroeger)

komt steeds lager te zitten en ook

5. kijk je zo nauw niet meer tenslotte

wat is het verschil helemaal

waar gaat het helemaal over?

mijn pen moet beter gewend

zijn want anders schreef ik

10. nu zonder meer:

$\cdots$

en

$\cdots$

( = fuck \& shit)

Het lijkt me niet aannemelijk, dat Warmond gelijk heeft met haar opvatting dat dergelijke kritiek beperkt is tot Nederland. In haar boek Andere levens, andere letteren (Amsterdam 1985) geeft Joanna Russ een groot aantal voorbeelden van soortgelijke opmerkingen van mannelijke critici t.a.v. Engelstalige vrouwelijke auteurs. Neder-

36 in: Testberld voor koud klimaat. Amstendam 1966: 36 
lands onderzoek bevestigt dit beeld. In Een hoofdstuk apart (1992) heeft Erica van Boven de negatieve beeldvorming onderzocht in de literaire kritiek in de periode 1898-1930 ten aanzien van de zogenaamde 'vrouwenroman'. Van Boven toont aan, dat ideologieën over de vrouw sterk hebben doorgewerkt in literaire kritieken. ${ }^{37}$ Marianne Vogel toonde in het eerder door mij besproken Baard boven baard (2001) onder andere aan, dat recensenten in de periode 1945-1960 het literaire werk van vrouwelijke auteurs anders beoordelen dan dat van mannelijke auteurs. Om te weten te komen of en in hoeverre er inmiddels op dit terrein iets veranderd is, verdient het aanbeveling dat er een soortgelijke studie komt over de periode 1960-2000.

Niet alleen mannelijke critici blijken moeite te hebben met het feit dat Warmond niet in de klassieke kaders van vrouwelijkheid is onder te brengen.In een interview in Het Vaderland van 31 augustus 1957 schrijft de interviewster Dorothea Ensing teleurgesteld (cursivering van $\mathrm{mij}$ ):

Ze praat zo vaardig, zo gemakkelijk, behalve over zichzelf. [...] Hoe vrouwelijk verder ook, de typische eigenschap van 'er 's lekker voor gaan zitten om over jezelf te praten' heeft zij niet, of ... toonde ze niet.

Zowel Morriën als Ensing. en zij niet alleen, geven aan dat Warmond als auteur en als persoon niet congrueert met de gangbare opvattingen over vrouwelijkheid. $\mathrm{Zij}$ is niet te plaatsen binnen het gangbare genderconcept met de culturele constructies van mannelijkheid en vrouwelijkheid. Het resultaat van gender is, aldus Margo Brouns, onder andere dat wij 'mannen' en 'vrouwen' waarnemen. ${ }^{38}$ Het proces van identiteitsvorming wordt bepaald door al dan niet subtiele codes: geboden, verboden en voorbeelden stellen 'dit is een vrouw' dan wel 'dit is een man'. In het genteronderzoek wordt onderscheid gemakt tussen sociale identiteit en subjectieve identiteit, twee bruikbare concepten om an te geven waardoor er verwarring kan ontstaan. Sociale identiteit is die warop men wordt ingedeeld en eventueel gewaardeerd of gediscrimineerd, terwijl subjectieve identiteit (het zelfbeeld) de persoonlijke identificatie daarmee is. Deze twee lagen vallen niet samen, maar zijn ook niet duidelijk van elkaar te onderscheiden. Het is overigens juist de tussenruimte die een spel met de traditioneel bepaalde identiteit mogelijk maakt, zoals bijvoorbeeld blijkt uit het optreden van David Bowie of Madonna, aldus Brouns. Zowel Morriën als Ensing lijken het traditionele genderconcept geinternaliseerd te hebben. Bij hen is er een nauwere samenhang tussen sociale en subjectieve identiteit dan bij Warmond. Vandaar hun verwarring en poging om haar weer in het traditionele genderhokje te krijgen.

37 Erica van Boven, Een hoofdstuk apart. 'Vrouwenromans' in de literaire kritiek 1898-1930. Amsterdarn 1992

38 Margo Brouns (m.m.v. Mieke Verloo), 'Kernconcepten en debatten.' In: Vrouwenstudies in de jaren negentig. Bussum 1995: 29-51 
Bij Warmond vallen sociale en subjectieve identiteit dus minder samen dan vanuit traditionele opvattingen wenselijk wordt geacht. Betekent dit, dat Warmond zich daardoor aangesproken voelt door het feminisme, een beweging die onder meer in opstand komt tegen traditionele sekse-opvattingen? Uit diverse interviewfragmenten en dergelijke blijkt, dat haar houding ambivalent is. Met de grondstellingen is ze het eens, maar ze moet niets hebben van 'detailfeminisme':

Wat het feminisme zou moeten bereiken is, dat ons hele denkpatroon, het masculinistische denken verandert, want de grondslag veranderen, is de enige methode. En dat is niet zo'n gemakkelijke opgave. Dingen als vrouwenhuizen zijn natuurlijk heel nuttig, maar het zijn toch pragmatische oplossingen voor details. ${ }^{39}$

Interessant in dit verband is een reactie van Warmond op een artikel van de Belgische auteur Lucienne Stassaert, waarin laatstgenoemde reageerde op de door Daniël Robberechts serieus bedoelde vraag: 'Waarom schrijven vrouwen gewoonlijk slecht, waarom zijn de vrouwen die goed schrijven buitenbeentjes (psychologisch-sociologisch)? ${ }^{40}$

Distantie ten aanzien van haar seksuele bepaaldheid levert de vrouwelijke auteur een haarscherp bewustzijn, observatievermogen plus een grotere vrijheid van vorm en inhoud op, aldus Stassaert. De homoseksuele auteur staat volgens haar door haar maatschappelijke uitzonderingspositie in een andere verhouding tot de traditie. Om een aandeel te veroveren IN de wereld is volgens Stassaert een creatief nihilisme vereist om te kunnen onderzoeken wat niet vanzelfsprekend is. Met nihilisme bedoelt zij: een drijfveer om de door de maatschappij vastgelegde waarden en begrippen te ontleden en ter discussie te stellen (bijvoorbeeld de sociale machtsstructuur, de seksualiteit en het enorme aandeel van de christelijke optiek). Stassaert vroeg een aantal schrijfsters om een reactie, onder wie Miep Diekmann en Ellen Warmond. Miep Diekmann reageert als volgt:

Ik begrijp niet goed dat vrouwen een dergelijke vraag nog willen beantwoorden, daardoor laten ze zich weer in diezelfde antieke hoek drukken. [...] Durven ze bij jullie nog altijd niet gewoon: Stik! op zo'n vraag zeggen?

De reactie van Warmond is interessant genoeg om wat uitvoeriger te citeren, omdat hieruit blijkt, dat zij losstaat van cultureel bepaalde opvattingen over vrouwen en kunstenaressen:

39 L. Heyting, 'Ik sla niet meer zo hard op tafel.' NRC. Handelsblad 10-8-1979

40 Lucienne Stassaert, 'Waarom schrijven vrouwen gewoonlijk slecht?' In: De Vlaamse Gids, 56, november, 11, p. 4-13 (met reacties van Diekmann en Warmond) 
[...] Het merkwaardige van dit soort artikelen is dat ze allemaal één ding gemeen hebben: de uitdagende vraag is door een man gesteld, zodat de antwoordende vrouwen meteen in de verdediging worden gedrongen, i.p.v. gelegenheid te hebben hun standpunten te overzien. Bovendien vind ik eigenlijk dat je je tijd beter kunt besteden aan het bewijzen van de onjuistheid van de stelling dat vrouwen zoveel slechter zouden schrijven en wel door goed te schrijven.

[...] Wie zich inspant de vraag te beantwoorden gaat eigenlijk eerst van de veronderstelling uit dat de vraag zo juist gesteld is, terwijl de vraag hoogstens zou kunnen luiden: 'Is het waar dat er kwalitatief verschil bestaat tussen de literaire producten van mannen en vrouwen?', en zelfs dan zou men nog aan mannelijke auteurs kunnen vragen eerst eens te bewijzen dat zij, door de band genomen, zoveel beter schrijven ... Een begin van emancipatie zou al moeten liggen in het zelf kiezen van het onderwerp waarover vrouwen willen schrijven en niet gehoorzaam (of geïrriteerd) inhaken op een uitdaging als deze.

[...] het sterkste wapen tegen discriminatie -op welk gebied en in welke vorm dan ook- lijkt me nog steeds (en is in de praktijk gebleken te zijn) niet het verweer tégen, maar het negéren van die discriminatie. In sommige gevallen zal daar inderdaad een beetje 'geweld' aan te pas moeten komen, maar 'à vaincre sans péril on triomphe sans gloire', zoals mij op school in een heel ander verband geleerd is ...

Toen een interviewer het volgende citaat -overigens incorrect- aanhaalde uit het juryrapport van de Anna Bijns Prijs: 'De wereld is in het werk van Ellen Warmond niet langer vanzelfsprekend mannelijk' ${ }^{41}$ reageerde Warmond. hierop verbaasd met: 'Voor wie dan wel?' In haar dankwoord tijdens de uitreiking van de Anna Bijns Prijs plaatste Warmond discriminatie van vrouwen in een bredere context. Alle vormen van onrecht en discriminatie van alle minderheden komen in haar visie voort 'uit één en dezelfde stinkende poel'.

\section{Conclusie}

In dit hoofdstuk onderzocht ik een aantal abstraheringstechnieken in het werk van Warmond. Woorden als 'men' en 'je' in de functie van onpersoonlijk naamwoord worden gebruikt om individuele ervaringen, gevoelens en dergelijke uit het beperkte kader van het particuliere te halen en daardoor te veralgemenen. Dat geldt

41 het correcte citaat luidt: "De vrouwelijke stem is onder andere het gezichtspunt van waruit de wereld niet langer vanzelfsprekend mannelijk is." Myriam Diaz-Diocaretz, Juryrapport Anna Bijns Prijs 1987. Den Haag 1987:21 
ook voor de gedichten waarin het substantief voorafgegaan wordt door een lidwoord in categoriale functie.

Een speciale groep vormen de zogenaamde hij-gedichten, die in twee categorieën zijn onder te verdelen. In de eerste categorie is de hij-vorm een middel om afstand te nemen van een bepaald mannelijkheidsideaal. In de tweede categorie heeft de hij-vorm een exemplarisch effect. Uit de omzettingsproef bleek, dat de hij-vorm in bepaalde gevallen ook stilistisch gemotiveerd is vanwege een grotere dramatische kracht.

Vervolgens besprak ik nog twee andere abstraheringstechnieken: het inventariserende effect van de tot voltooid deelwoord gereduceerde werkwoordsgroep en het programmatische effect van de tot infinitief gereduceerde werkwoordsgroep.

De sekse-neutraliteit ten slotte blijkt, in ieder geval tot 1970, een versluieringstactick te zijn om niet expliciet aan te hoeven geven dat het in bepaalde gedichten om de damesliefde gaat. Verder blijkt uit een aantal interviews, een column en een artikel dat Warmond sekse-onderscheid niet relevant vindt. Begrippen als 'mannelijk' en 'vrouwelijk' vindt zij onwerkbaar, zeker in de kunst. 
| 176 | 


\section{POËZIE EN ENGAGEMENT}

\section{Inleiding}

Engagement, zowel maatschappelijk als politiek, is in diverse literair-existentialistische werken een belangrijk thema. Voorbeelden daarvan zijn La peste (1947) van Albert Camus en Les mandarins (1954) van Simone de Beauvoir. In La peste, waarin de inwoners van de stad Oran geïsoleerd raken vanwege een pestepidemie, staan een orthodox-christelijke en een existentialistische visie tegenover elkaar, gerepresenteerd door respectievelijk pater Paneloux en dokter Bernard Rieux. Volgens Paneloux is de pest een collectieve straf van God. Hij hoopt dat iedereen zich in vertrouwen tot de hemel richt: 'God zou zorgen voor de rest.' Rieux vindt deze fatalistische visie onacceptabel:

[...] wat voor alle rampen van deze wereld geldt, geldt ook voor de pest. Sommigen kunnen er geestelijk door groeien. Alleen, als je kijkt naar wat het kost, de ellende en de pijn, moet je wel gek, blind of laf zijn om je erbij neer te leggen. ${ }^{1}$

Als hij geloofde in een almachtige God, zou hij ophouden mensen te genezen om die zorg aan Hem over te laten, aldus de dokter tegen zijn vriend Tarrou. ${ }^{2}$ Rieux kiest voor de slachtoffers. Dat geldt ook voor de Parijse journalist Raymond Rambert, die uiteindelijk afziet van een vluchtpoging en uit solidariteit met de slachtoffers besluit in Oran te blijven.

Simone de Beauvoir behandelt in haar roman De mandarijnen onder meer de positie van de linkse intellectueel vlak na de Tweede Wereldoorlog. Het verhaal speelt zich voornamelijk af in de periode van de Vijfde Republiek (1947-1951), bijgenaamd de Republiek der Mandarijnen. Het is de tijd van Generaal De Gaulle, die een sterk centralistische politiek met veel persoonsgebonden macht voorstaat. De Beauvoir verwerkt in haar roman een conflict tussen Sartre en Camus over de stalinistische concentratiekampen. In de roman debatteren Henri Perron, die veel weg heeft van Camus, en Jean Dubreuilh, in wie Sartre te herkennen is, over de vraag of gegevens over deportatie en dwangarbeid in de Sovjetunie gepubliceerd moeten worden of niet. Publiceren van deze gegevens zou de rechtse, anti-communistische politici in de kaart spelen, aldus Dubreuilh. Perron kan dit standpunt echter niet met zijn geweten in overeenstemming brengen en neemt ontslag bij de krant. ${ }^{3}$

Niet alleen in romans, maar ook in toneelstukken wordt het engagement gethematiseerd. Voorbeelden daarvan zijn Les justes (1949) van Camus en Les mains sales

\footnotetext{
1 Albert Camus, De pert. In: Albert Camus, Bruiloft. De vreemdeling. De pest. De zomer. De nal. Amstendam 1993: 318

2 Camus 1993: 320

3 ontleend aan Ernst van Altena 'Mandarijnen pellen'. Nawoord bij de vertaling van Simone de Beauvorr, De mandarijnen. Amsterdam $1996^{18}: 713-726$
} 
(1947) van Sartre, die beiden in hun stukken het thema van de 'vuile handen' behandelen.

Opvallend afwezig in dit geheel is de poëzie. Wat is daar de oorzaak van en is dat terecht? Volgens Van Stralen (1996) hebben literaire existentialisten een voorkeur voor proza en drama vanwege hun interesse voor de dialoog, aangezien die een geschikt middel is om conflictsituaties en ideeën uit te werken. Daar kan ik enigszins in meegaan, maar het verklaart niet afdoende waarom de poëzie in dit verband buiten spel wordt gezet. Voor het tonen van engagement heb je niet per se veel ruimte of tijd nodig, getuige de over het algemeen slechts een paar minuten durende protestsongs of spandoekteksten als 'Ban de Bom'. Er zijn. volgens mij ook nog andere factoren die de geringe aandacht voor poëzie verklaren. Ten eerste richten publicisten over het literaire existentialisme zich vooral op grote voorbeelden als Sartre, Camus en De Beauvoir, die zelf geen gedichten publiceerden. Ten tweede heeft het te maken met Sartres visie op poëzie. Daarover meer in de volgende paragraaf.

\section{Sartre en de poëzie}

Sartres ideeën over poëzie houden verband met zijn opvattingen over de taak van de literatuur, die volgens hem de existentiële situatie en de vrijheid van het individu moet laten zien. In het essay Qu'est-ce que la littérature? ${ }^{4}$, waarin Sartre een beroep doet op de ethiek van de schrijver na de Tweede Wereldoorlog, is taal in de eerste plaats een middel om ideeën uit te drukken. De auteur moet niet alleen filosoferen over de waarheid, maar hij moet haar vooral ook tonen en aldus de lezer bewust maken van zijn vrijheid. Sartre acht de poëzie hier minder geschikt voor, omdat de dichter de taal niet zozeer ziet als een communicatief middel maar als een doel op zich. De dichter kent de woorden een magische autonomie toe. Poëzie hoort in dezelfde categorie als schilderkunst, beeldhouwkunst en muziek. Kleuren, vormen en noten zijn geen tekens, omdat ze naar niets buiten zichzelf verwijzen. Zoals de schilder met kleuren werkt en de musicus met klanken, zo werkt de dichter met woorden. Hij beschouwt het woord niet als een teken, maar als een ding, aldus Sartre.

In Sartres visie is een vage echo te horen van Plato's ideeën over poëzie. Hoewel Plato zelf epigrammen, dithyramben en tragedies heeft geschreven, verwerpt hij op een gegeven moment de poëzie of beter gezegd een bepaald soort poëzie. ${ }^{5} \mathrm{Bij}$ hem staat de inhoud centraal. Wat waar is, kan alleen in proza gezegd worden, omdat in proza de vorm niet de kans krijgt de inhoud te vervangen zoals dat in poëzie het geval is, aldus Plato. Alleen de inhoud van een boodschap maakt haar belangrijk, niet de vorm. Het werk van dichters uit zijn tijd is bovendien niet het resultaat van

4 ik heb gebruik gemaakt van de volgende editic: Jean-Paul Sartre, 'What is litenature?' and Otha Escarys. Cambridge 1988

5 zie: C. Verhoeven, Het medium van de watrheid. Beschouningen over Plato's houding tegenover de poezic. Baarn 1988 
autonoom denken. Ze geven alleen de traditie door met haar vanzelfsprekendheden, zonder kritische reflectie. De verzameling mooi klinkende woorden dreigt een gesloten wereld te worden zonder nog naar de werkelijkheid te verwijzen.

Plato wijst overigens niet alle dichtkunst af. Hij heeft geen bezwaar tegen poëzie die geen filosofische pretenties heeft en haar speelse karakter duidelijk toont, zoals de komedie en de satire. Het is namelijk noodzakelijk dat men het mooie van het lelijke en het belachelijke van het serieuze leert onderscheiden.

In Sartres visie op poëzie weerklinkt Plato's kritiek dat de mooi klinkende woorden van een dichtwerk een gesloten wereld vormen zonder nog naar de realiteit te verwijzen. Dat geldt ook voor het idee dat de vorm in poëzie de kans krijgt de inhoud te vervangen. Proza daarentegen stelt de inhoud centraal.

In Qu'est-ce que la littérature? verklaart Sartre de aversie van dichters tegen literair engagement vanuit een breder historisch perspectief. In dit essay geeft hij enkele voorbeelden van schrijvers die in de loop der tijd de bestaande ideologie bevestigd hebben. Dat zijn vooral auteurs die banden onderhielden met de kerk of met het hof. Ze hoefden zich niet af te vragen welke betekenis en waarde literatuur heeft, aangezien die betekenis en waarde door de traditie waren vastgelegd. De macht van de religieuze en politieke ideologie was zo sterk en zo streng ten aanzien van andersdenkenden dat er geen sprake kon zijn van het ontdekken van nieuwe gebieden in de geest, alleen maar van het vormgeven aan gemeenplaatsen van de elite, aldus Sartre. Pas tijdens de Verlichting weerspiegelde literatuur niet langer meer de collectieve gemeenplaatsen. Schrijvers identificeerden zich met de Geest, dat wil zeggen met de macht om op vrije wijze ideeën vorm te geven en te bekritiseren. Dit fundamentele conflict tussen de schrijver en zijn publiek had geen precedent in de literaire geschiedenis.

In de negentiende eeuw weigerde de literatuur de ideologie van clerus en bourgeois te dienen. Ze werd onafhankelijk van welke ideologie dan ook, maar werd darmee volgens Sartre zélf een ideologie, namelijk de ideologie van de autonome literatuur. Op experimentele wijze probeerde ze haar eigen wetten en nieuwe technieken te ontdekken. De l'art-pour-l'art-theorie, die daar een uiting van is, wijst Sartre af. Schrijvers die niets van literair engagement moeten hebben noemt hij katharen. Hij bekritiseert hun wereldvreemdheid: ze trekken zich terug in een etherische wereld, terwijl de werkelijke wereld naar de achtergrond verdwijnt en niet van belang wordt geacht.

De tijd dat de schrijver in dienst was van degenen die de wereld willen bezitten, is voorbij, stelt Sartre. Hij moet nu de kant kiezen van degenen die de wereld willen veranderen. De schrijver dient stelling te nemen tegen alle onrechtvaardigheden, van welke kant ze ook komen. Hij moet een beroep doen op de vrijheid van de mensen opdat ze zich van hun eigen vrijheid bewust worden. Sartre realiseert zich dat dit utopisch is. Hij heeft niet de illusie hiermee de wereld daadwerkelijk te kunnen veranderen. Bepaalde dingen moeten echter wel gezegd worden, al was het maar om je gezicht te redden tegenover je kinderen. Iedereen kan dat doen op zijn 
eigen manier, in zijn eigen stijl, met zijn eigen techniek, zajn eigen onderwerpen, aldus de Franse filosoof.

Het is overigens een misverstand, dat Sartre het over poëzie in het algemeen heeft. In het notenapparaat bij zijn essay benadrukt hij, dat zijn opmerkingen uitsluitend de contemporaine poëzie betreffen. Sartre ziet echter over het hoofd dat de taal bijvoorbeeld in hedendaagse epische, religieuze en politiek. geëngageerde poëzie wel degelijk ook als een communicatief middel gebruikt wordt, terwijl in experimentele romanvormen de taal veel meer een doel op zich is.

Sartre heeft elders zijn visie ten aanzien van poëzie genuanceerd. In 1948 verscheen een door Léopold Sédar-Senghor geredigeerde bloemlezing van Afrikaanse en West-Indische dichters: Anthologie de la nouvelle poésie nègre et malgache de langue française. ${ }^{6}$ Voor deze bundel schreef Sartre het voorwoord. In dit stuk, 'Orphée Noir', bespreekt hij de poëzie in de context van het kolonialisme. ${ }^{7}$ Poëzie is in dit verband wel degelijk een middel om sociale veranderingen te bewerkstelligen. De zwarte dichter is op zoek naar een eigen taal en eigen uitdrukkingsvormen. Zijn poëzie is een bewustwordingsproces. Omdat hij onder druk van de kolonisatie verbannen is van zijn eigen lichaam en hart, heeft hij de behoefte zichzelf weer te vinden. Sartre noemt deze poëzie orphisch, omdat de dichter af moet dalen in zichzelf. Deze afdaling doet Sartre denken aan Orpheus die Eurydice terugeist van de onderwereld.

De zwarte dichters uit de bloemlezing verkeren in een ambivalente positie: ze verklaren in het Frans dat ze de Franse cultuur afwijzen. Omdat de onderdrukker aanwezig is in de taal die zij spreken, moet de taal van binnenuit veranderd worden. De poëzie is daar uitermate geschikt voor, aangezien de betekenissen in dit genre minder gefixeerd zijn dan in proza, aldus Sartre.

\section{Engagement in Nederland}

Vlak na de Tweede Wereldoorlog zijn er in Nederland dichters die het politieke en maatschappelijke engagement niet uit de weg gaan, ook niet in hun werk. Harry Scholten stelt in zijn artikel 'Lyriek is de moeder der politiek' ${ }^{18}$ dat de Vijftigers, die overigens geen partijprogram hadden, in hụ streven naar vernieưwing van de poëzie ook generatiegevoelens van onvrede met de maatschappelijke ontwikkelingen hebben verwoord. Het bekendste voorbeeld is 'Minnebrief aan onze gemartelde bruid. Indonesia' van Lucebert.

De Vijftiger die het meest in verband gebracht wordt met rechtstreeks politiek engagement is Jan G. Elburg. Hoewel hij nooit lid geweest is van de CPN heeft hij zich wel voor deze partij ingezet. Hij hield voordrachten tijdens protestbijeenkom-

6 'Malgache': van Madagascar

7 'Black Orpheus.' In: Jean-Paul Sartre, 'What Is Litenture?' and Other Essarys Cambridge, Massachussetts 1988: 291-330.

8 Harry Scholten, 'Lyriek is de moeder der politick. Opvattingen over poëzie en matschappeliyk engagement in de dichtersbeweging der Vijftigers.' in: Litenatuur, Utrecht 1984, afl. 1. p. 13-18 
sten en werkte mee aan communistische vakantickampen voor kinderen van de Amsterdamse eilanden. Bovendien schreef hij gedichten en liederen als materiaal voor verkiezingspropaganda van de partij. Het engagement van Elburg ontwikkelde zich later tot een algemene betrokkenheid bij de medemens en zijn wereld, aldus Peter Bormans in zijn studie over Elburg. ${ }^{9}$ Bormans vergelijkt Elburgs poëzie met het werk van enkele Nederlandse dichters warin het socialisme een overheersende rol speelde. Eind negentiende eeuw en begin twintigste eeuw kent Nederland tot aan de Tweede Wereldoorlog een traditie van kunstenaars die zich op de een of andere manier betrokken voelden bij het socialisme: Van Eeden, Heijermans, Adama van Scheltema, Gorter en Henriëtte Roland Holst. Volgens Bormans zijn de meest linksen onder de Vijftigers wellicht de laatste uitlopers van die traditie.

Hoewel de vraag om meer werkelijkheid in de poëzie dringender wordt in de vijftiger jaren, speelt een belangrijke gebeurtenis als de Tweede Wereldoorlog nauwelijks een rol in de Nederlandse poëzie van direct na de oorlog, aldus Redbad Fokkema in zijn overzicht van de Nederlandse poëzie sinds 1945 . Hij verwijst daarbij naar een uitspraak van de Engelse dichter W.H. Auden: 'poetry makes nothing happen'. Elders heeft Auden dit standpunt genuanceerd. Niet alleen de poëzie kan niets veranderen, ook andere kunsten kunnen dat niet, maar dat is ook niet hun taak:

Artists and politicians would get along better in a time of crisis like the present, if the latter would only realise that the political history of the world would have been the same if not a poem had been written, not a picture painted nor a bar of music composed. If the criterion of art were its power to incite to action, Goebbels would be one of the greatest artists of all time. Tolstoi, who, knowing that art makes nothing happen [accentuering van mij], scrapped it, is more to be respected than the Marxist critic who finds ingenious reasons for admitting the great artists of the past to the State Pantheon. ${ }^{10}$

Volgens Auden, die zeker tot de geëngageerde dichters gerekend kan worden, zullen er altijd twee soorten kunst zijn: 'escape-art', die net zo nodig is als eten en slapen, en 'parable-art, that art which shall teach man to unlearn hatred and learn love." ${ }^{11}$ Dit impliceert echter niet, dat de dichter zich ten dienste moet stellen van een of andere partij:

The propagandist, whether moral or political, complains that the writer should use his power over words to persuade people to a particular course of action, instead of fiddling while Rome burns. But Poetry is not concerned with telling people what to do, but with extending our knowledge of good and evil,

9 Peter Bormans, "Ik hoop dat ik stoor". De poizzie nan Jan G. Elbung (1919-1992). Brussel z.j.: 289

10 geciteerd in Charles Osborne, WH. Auden. The Life of a Poet. New York 1995: 183

11 geciteerd in: Samuel Hynes, The Auden Genenation. Literature and Politics in England in the 1930s. Princeton $1976^{2}: 168-169$ 
perhaps making the necessity for action more urgent and its nature more clear, but only leading us to the point where it is possible for us to make a rational and moral choice ... One must show those who come to poetry for a message, for calendar thoughts, that they have come to the wrong door, that poetry may illuminate but it will not dictate. ${ }^{12}$

Fokkema vraagt zich af of er van de Tweede Wereldoorlog wel poëzie te maken is. Mijn antwoord luidt: waarom niet? Door de eeuwen heen bekeken blijkt dat de poëzie geen enkel onderwerp uit de weg is gegaan; niet het onderwerp maar de vormgeving bepaalt of er sprake is van poëzie of niet. Voorbeelden die de impliciete stelling van Fokkema ondermijnen zijn te vinden in het vroege werk van dichters als Bert Voeten, Sybren Polet en Ed. Hoornik, waarin de oorlog en de nawerking daarvan wel degelijk terug te vinden zijn. Ook uit latere gebeurtenissen blijkt, dat de Nederlandse poëzie niet zo a-politiek is als wel eens gesuggereerd wordt. Offermans' stelling dat buiten Alain Teister geen enkele Nederlandse dichter zich destijds heeft laten inspireren door Vietnam, Cuba, Parijs of Praag haalt Redbad Fokkema overigens overtuigend onderuit door een aantal tegenvoorbeelden: Hanny Michaelis, Maurits Mok, Hans van de Waarsenburg, Gerrit Kouwenaar en Ellen Warmond. ${ }^{13}$

Toen in 1965 de eerste Amerikaanse troepen in Vietnam arriveerden, waren ook in Nederland de meningen over deze 'interventie' verdeeld. Demonstranten werden beschouwd als gevaarlijke dissidenten, omdat ze een bedreiging voor de eenheid in. het Westen zouden vormen. Pas door de aanhoudende bombardementen en het gebruik van napalm veranderde de publieke opinie. Toen in 1973 een bestand in. Vietnam tot stand kwam was bijna iedereen tegen de oorlogvoering. ${ }^{14}$

in onderstaand, titelloos, gedicht legt Hanny Michaelis een associatief verband tussen het doodspuiten van een mug en de chemische oorlogvoering in Vietnam, waardoor het geweld ineens concreet wordt en heel dichtbij komt:

Voor het slapen gaan

een bloeddorstige mug

met de spuitbus vastberaden

achtervolgen. Liever niet

5. kijken naar het machteloze

gespartel, de langzaam verstijvende

pootjes, het gekromde lijf. Daarna

wakker liggen van ontzetting

over de honderden mensen

12 geciteend in Samuel Hynes $1976^{2}: 166-167$

13 Redbad Fokkema, Aan de mond uan al die rivienen. Een geschiedenis van de Nederlandse poézie sinds 1945 Amsterdam 1999: 298

14 gegevens ontleend aan: Kees Schuyt, Ed Taverne, 1950 Wehuart in zuarn-wit. Nedcrlandse cultuar in Europese context deel IV. Den Haag 2000 
10. die op dit ogenblik kreperen aan de wonden die ze elkaar opzettelijk en geestdriftig hebben toegebracht:

in Vietnam uiteraard. ${ }^{15}$

De Vietnam-oorlog wordt ook wel de 'televisie-oorlog' genoemd, omdat de televisie vrijwel iedere dag beelden daarvan uitzond. In 'Groeten uit Vietnam en omstreken' gaat Ellen Warmond daarop in. ${ }^{16}$ Met de titel is iets vreemds aan de hand. De term 'en omstreken' slaat op het omliggende gebied van een dorp of een stad, niet op dat van een land. Warmond verruimt in dit gedicht dus de gebruiksmogelijkheden van deze uitdrukking. De televisie heeft ervoor gezorgd, dat de wereld dichterbij kwam en kleinschaliger leek dan daarvoor.

De titel, die in eerste instantie idyllische associaties oproept, vormt een scherp contrast met de inhoud van het vierdelige gedicht, dat geschreven is naar aanleiding van televisiebeelden van de oorlog in Vietnam. Een voorbeeld daarvan is het vierde deel:

4

Vanavond zag ik een man

op schoenen

een man zonder schoenen schoppen

zijn magere rug lag als

5. een voorwerp in het zand

en niemand keek er naar om

een halfnaakte man vertrapt

door een aangeklede

en miljoenen keken ernaar

10. dronken koffie rookten zwegen

of zeiden het is weer niks

die TV vanavond.

Bij oppervlakkige lezing lijkt dit vers de anekdotiek niet te ontstijgen, maar op literair/formeel niveau gebeurt er wel degelijk iets waardoor het als gedicht aan diepgang wint. In de eerste strofe is er sprake van twee personen, waarschijnlijk een

15 in: Wegdraven naar een nicuw utopia (1971). In: Hanny Michaels, Veramelde gedichten. Amstendam 1996: 203

16 in: Geen bloemen geen bezock. Amsterdam 1968: 29-33 
Amerikaans soldaat en een Vietnamese man. De regels 4-6 roepen een beeld op van ontmenselijking ('als een voorwerp') en totale verlatenheid ('niemand keek er naar om') van het Vietnamese slachtoffer. De term 'vertrapt' in r. 7 geeft niet alleen aan dat de man (mede?) ten gevolge van het trappen is overleden, maar roept ook de vernederende en gewelddadige sfeer op waarin dat gebeurd is.

Niet alleen het slachtoffer is ontmenselijkt, ook bij de dader is dat het geval. Het woord 'aangeklede' in r. 8 is een bijvoeglijk naamwoord bij het samengetrokken element 'man', maar je kunt het ook interpreteren als een zelfstandig naamwoord. In dat geval lijkt het woord 'aangeklede' de Amerikaan te reduceren tot zijn kleding, zijn uniform, tot iemand waaruit alle menselijkheid verdwenen is.

De onverschilligheid in r. 6 ('en niemand keek er naar om') wordt als het ware geëchood in de laatste regels van het gedicht. Het veelvuldig zien van gruwelijke oorlogsbeelden leidt bij veel kijkers tot een zekere vervlakking. Het is alsof de oorlog alleen maar op de televisie plaatsvindt, alsof er geen relatie is tussen beeld en. werkelijkheid. Ook daardoor verliezen oorlogsslachtoffers hun persoonlijke identiteit. Het tweede deel van 'Groeten uit Vietnam en omstreken' is interessant door een verwijzing naar de poëzie van vóór 1940:

Nu zullen er misschien wel mensen zijn

die zeggen

dat poëzie vandaag de dag

weer gaat over de dingen des

5. gemenen levens

zoals vóór "40:

toen er een kind verdronken was ik meen

bijmonde van eddy hoornik

in middelharnis

10. alleen doen wij vandaag

de dag die dingen

meer in het groot.

Warmond verwijst in dit gedicht naar Ed. Hoornik (1910-1970), die samen met de dichters Gerard den Brabander (1900-1968) en Jac. van Hattum (1900-1981) tot de zogenaamde Amsterdamse school behoort. In een tijd die gedomineerd wordt door een economische crisis, de opkomst van het fascisme en de dreiging van een wereldoorlog schrijven zij sociaal bewogen verzen in een realistische stijl, waarbij ze 
valk uitgaan van actueel-anekdotische motieven. ${ }^{17}$ Zo schreef Hoornik gedichten als 'Emigrant', 'De vluchteling' en 'Pogrom'. Het laatste gedicht, geschreven naar aanleiding van een pogrom in Berlijn, is vooral bekend geworden vanwege de laatste, dreigende regel: 'Het is maar tien uur sporen naar Berlijn.' ${ }^{18}$

In 1940 richt Hoornik samen met Cola Debrot en Han G. Hoekstra het tijdschrift Criterium op. Ze zijn geïnteresseerd in een synthese van romantiek en rationalisme, door hen aangeduid als 'romantisch rationalisme'. Hoornik zal later erkennen dat dit niet zo zeer een programma was, als wel een noemer waar vele dichters onder konden vallen. De Vijftigers, die zich richtten op 'de ruimte van het volledig leven', hebben zich laatdunkend uitgelaten over de zogenaamde Criterium-dichters, warbij een regel uit het gedicht 'Fanfare-corps' van Vasalis zou gaan dienen als etiket voor de Criterium-poëzie: 'eerbied voor de gewoonste dingen'. Ton Anbeek heeft erop gewezen dat deze poëzie ten onrechte dit etiket heeft gekregen. Ten eerste heeft Vasalis nooit poëzie gepubliceerd in Criterium. Ten tweede bestaat er niet zoiets als Criterium-poëzie door de diversiteit aan dichters, stijlen en onderwerpen. Ten derde vindt men in het tijdschrift veel werk van Gerrit Achterberg, op wiens werk men toch moeilijk het bovengenoemde etiket kan plakken. ${ }^{19}$

Warmonds 'Groeten uit Vietnam en omstreken 2' bevat een verwijzing naar een bekende dichtregel van Hoornik: 'Te Middelharnis is een kind verdronken', afkomstig uit de zestiendelige gedichtenreeks Requiem (1938). Ik citeer het eerste gedicht:

Te Middelharnis is een kind verdronken.

Sober berichtje in het avondblad:

onder een hooiberg die had vlam gevat

en naast een zolderschuit, die was gezonken.

5. Zes dagen heeft het in mij nageklonken.

Op het kantoor vroeg men: zeg, heb je wat?

Ik werkte door, maar steẹds weer hoorde ik dat:

te Middelharnis is een kind verdronken.

En kranten waaien weg en zijn verouderd,

10. de dagen korten, nachten worden kouder,

maar over ' $t$ water komt zijn kleine stem.

Te Middelharnis, denk ik, 'k denk aan hem

en bed zijn hoofdje tussen hart en schouder,

en zing voor hem dit lichte requiem.

17 ze G.J. Bork en N. Laan (red.), Tivee ceumen litenafuurgeschiedenis. Poeticale opuartingen in de Nederlandse litenutuar. Groningen 1986: 223-223

18 de genoemde gedichten verschenen in de bundel Beelden (1938). Ze zjn ook te vinden in Ed. Hoornik, Verzamelde gedidnen. Amsterdam 1972 op respectievelijk p. 94,95 en 93.

19 zie Ton Anbeek, Geschiedenis uan de Nederiandse litenatuur tussen 1885-1985. Amsterdam 19902:177 
Het enige verschil met de dichters van toen is, aldus Warmond, dat 'wij', contemporaine dichters, 'die dingen / meer in het groot' (r. 11-12) doen: we schrijven niet over Middelharnis maar over Vietnam; niet over een verdrinking maar over de verschrikkingen van de oorlog; niet over de dood van een kind maar over de vele oorlogsslachtoffers.

'Groeten uit Vietnam en omstreken 2 ' bevat in r. 4-5 een allusie op de bekende dichtregel van Vasalis 'eerbied voor de gewoonste dingen', waarmee de poëzie van vóór 1940 van dichters als Hoornik en Van Hattum gekarakteriseerd wordt. Warmond levert door middel van haar voorbeelden cynisch commentaar op deze kwalificatie, zowel wat de poëzie van vóór 1940 betreft als die van 'vandaag de dag' (r. 3) ${ }^{20}$ Ze lijkt een contrast te scheppen tussen de gebeurtenis in Middelharnis en. de grootschalige ellende in Vietnam, maar tegelijkertijd komen beide gebeurtenissen dichter bij elkaar. De term 'gemeen' betekent immers niet alleen alledaags, maar ook gemeenschappelijk. Maar net zo min als de verdrinkingsdood van een kind tot de 'dingen des gemenen levens' behoort, net zo min behoren de door de televisie uitgezonden oorlogsbeelden uit Vietnam daartoe. Ook al zorgen de media, vóór de oorlog met name de krant en nu vooral de televisie, ervoor dat dit soort gebeurtenissen 'gewoon' zijn geworden.

Hoewel er na de Tweede Wereldoorlog dus wel degelijk sprake is van Nederlandstalige geëngageerde poëzie, is het de vraag of dit genre zo'n prominente plaats innam als gesuggereerd wordt door de auteurs Jan Bervoets en Hans Ramaer in Maatstaf 1989. Zij presenteren de dichter van rond 1960 als 'een luidruchtige avonturier, een veroveraar van de vrijheid, waarvan zijn werk de representatie was. ${ }^{21}$ In de interviewbundel Engagement of escapisme? spreekt Fernand Auwera na vijftien jaar opnieuw met een aantal auteurs over de vraag in hoeverre engagement een rol speelt in hun leven en in hun werk. ${ }^{22}$ Volgens Hans van de Waarsenburg, een van de geinterviewden, kende Nederland in tegenstelling tot Duitsland, Frankrijk en de Verenigde Staten in de jaren zestig slechts weinig politiek-geëngageerde dichters. ${ }^{23}$ Er was slechts sprake van. een "klein randverschijnsel". ${ }^{24}$ Dit beeld. wordt bevestigd in Nederlandse literatuur, een geschiedenis. Schrijvers spraken zich eind jaren zestig

20 Rodenko heeft de poëzie van Warmond eens - ten onrechte mijns inziens- gekarakteriseerd als een 'transpositic in het experimentele' van de oude Criterium-poëzie. Zie Paul Rodenko, Verzamelde essays en kritieken deel 1. Amsterdam 1991: 141-143

21 Jan Bervoets en Hans Ramaer, 'Portfolio, Van kunstenaarsopstand tot engagement. Literatuur en politick in de jaren zestig' In: Maatstaf 1989,jg. 37, afl. 8-9, p. 52-84

22 Fernand Auwera, Engagement of eccapisme? Nieuue gesprekeken met Emst uan Altena, J. Bernlef, Jan Christiaens, Miep Dickmann, Jef Geenuerts, Rob un Gennep, Gust Gils, Hella S. Haasse, H. F. Jespers, Gemit Kounenaar, Hubert Lampo, lvo Michiels, Harry Mulisch, Wand Ruyslinck, Adriaan wan der Vecn, Hans van de Wharsenbung, Julien Weverbengh, Paul de Wispelacre. Weesp/Antwerpen 1985. De vijftien jaar daarvoor: gehouden gesprekken zijn onder andere gebundeld in Schrijven of schieten? Weesp/Antwerpen 1969

23 in studies over poëzie en politiek engagement beperkt men zich meestal tot het werk van mannelijke dichters. Het vendient aanbeveling het werk van geëngageende vrouwelijke dichters als Lizzy Sara May, Sonja Prins en Ellen Warmond nader te onderzoeken. Wat de geëngageerde poëzie van. Warmond betreft, is dit hoofdstuk een eerste aanzet.

24 in: Auwera 1985: 138. 
weliswar uit over actuele politieke gebeurtenissen, maar er was nauwelijks sprake van een direct geëngageerde literatuur, dat wil zeggen een literatuur die rechtstreeks reageert op de actualiteit. Slechts een enkeling als Hans van de Waarsenburg presenteerde zich uitdrukkelijk als politiek dichter. ${ }^{25}$

Politiek-maatschappelijk engagement speelde een grotere rol op toneelgebied. Met name jonge acteurs en regisseurs gingen op zoek naar repertoire dat meer aansloot bij de problematiek van hun eigen tijd. Bovendien ging men in werkgroepen experimenteren met andere spelvormen, waardoor al improviserend nieuwe stukken ontstonden. Ook in andere theatervormen hielden kunstenaars zich bezig met een actualisering van het repertoire. Een voorbeeld daarvan is de opera Reconstructie uit 1969, waar onder meer Harry Mulisch aan meewerkte. ${ }^{26}$ In deze opera staat solidariteit met de Latijns-Amerikaanse guerrilla en Che Guevara centraal. ${ }^{27}$

\section{De geëngageerde Warmond}

In De lust tot lezen (1988) presenteert Maaike Meijer dichters als Warmond, Michaelis en De Vreede als representanten van de 'Grote Melancholie'. Hiermee duidt ze een karakteristiek thematisch complex aan in de poëzie van vrouwen dat niet terug te vinden zou zijn in de poëzie van mannen. De gedichten hebben een depressieve teneur: het leven wordt als nutteloos ervaren, er is geen belangstelling voor anderen of voor de buitenwereld en er is sprake van zelfverachting en berusting. Meijer erkent dat nihilisme en wanhoop ook in mannenpoëzie voorkomen, maar daar hebben deze verschijnselen een agressieve component. Mannen gaan tekeer tegen de oude moraal, tegen de oude esthetiek, tegen hun voorgangers, maar niet tegen zichzelf, aldus. Meijer. De tegenhanger van de Grote Melancholie is het pre-feministisch bewustzijn, vertegenwoordigd door dichters als Vasalis, Noordzij en Peijpers. Volgens Meijer ontwikkelt hun aanvankelijke depressie zich geleidelijk an tot (pre)-feministisch onbehagen of zelfs rebellie.

Meijer beperkt zich in haar studie tot de periode 1950-1960 en in die jaren bevat het werk van. Warmond inderdaad weinig politiek-maatschappelijk engagement, op enkele gedichten in de bundels Naar men zegt (1955) en Weerszij van een wereld (1957) na. ${ }^{28}$ Later zal dit veranderen. Met name in de periode $1963-1972$ is er in diverse bundels van Warmond sprake van geëngageerde poëzie, zoals gedichten over de Tweede Wereldoorlog en de gevolgen daarvan voor de overlevenden, de

25 Anthony Mertens, '28 juni 1969 Première van de opera Reconstructie. Het politick-maatschappelijke klimaat in de jaren zestig." In: M.A. Schenkeveld-van der Dussen (hoofred.), Nederlandse literatuur, em geschiedenis. Groningen 1993: 807-813.

26 zie voor Mulisch' engagement:J.A. W. Buurlage, Onvenunderlijk venanderlijk. Harry Mulisch tussen litenatuur, journalistiek, wetenschap en politiek in de jaren zestig en zeventig. Amsterdam 1999

27 zie: Kees Schuyt, Ed Taverne, 1950 Welvaart in zwart-wit. Nederlandse cultuur in Europese context deel IV.Den Haag 2000: 425

28 namelijk: in Naar men zegt (1955) het geducht 'Een reisverhaal' (p. 22) en in Weerszij van ecn wereld (1957) de gedichten 'Broeders en zusters' (p. 11), 'Hagepreek' (p. 12) en 'Ballade van de ondervoede onschuld (p. 45-46) 
Vietnam-oorlog, rassendiscriminatie en politieke gevangenen. ${ }^{29}$ Daarnaast verschenen er een paar gedichten waarin de oorlog, als verschijnsel en de oorlogstechnologie op scherpe wijze aangeklaagd worden. ${ }^{30}$

Geeft het toenemende maatschappelijke engagement in de bundels De groeten aan andersdenkenden 1970) en Saluutschot met knaldemper (1972) een breuk aan met de existentialistische thematiek, zoals Pelgrom in zijn scriptie Ellen Warmond en het existentialisme suggereert? Deze suggestie lijkt mij onjuist. Pelgrom versmalt het existentialisme ten onrechte door het politieke engagement buiten zijn bespreking te houden. Politieke betrokkenheid heeft al vrij vroeg, namelijk vanaf 1944, samen met verwante termen als keuzevrijheid en verantwoordelijkheid, een rol gespeeld in het existentialisme. ${ }^{31}$ Sartre noemt zijn leer zelfs optimistisch, omdat het een op handelen gerichte leer is.

In een interview uit 1971 legt Warmond uit waarom de buitenwereld een steeds groter accent krijgt in haar werk:

misschien ook naarmate je ouder wordt om de doodeenvoudige reden dat je de binnenwereld wel gezien hebt, die inventaris heb je opgemaakt en wat daar verder aan moord en brand aan de gang is, daar ben je zelf verantwoordelijk voor en daar valt al of niet weinig aan te veranderen. Maar die buitenwereld verandert nog wel steeds zonder dat je daar veel aan kan toe of af doen en ik vind dat je dan op z'n minst voor jezelf moet uitmaken: vind ik dat goed of vind ik dat niet goed. ${ }^{32}$

Het gedicht 'Waar of niet? ${ }^{33}$ bevat een neerslag van deze visie:

Belachelijk war of niet? poëzie in deze tijd van ...

verzin zelf maar of lees een krant

hoewel

29. respectievelijk in 'Een reisverhal' (Naar men zegt 1955:22) en 'Adam Kadmon. Ziekentroost aan Willy Lages; tevens ter nagedachtenis' (Geen blocmen geen bezoek 1968: 34); 'Groeten uit Vietnam en omstreken' (Geen bloemen geen bezoek 1968: 29-33); 'New map of Via Dolorosa' (De groeten aan anders. denkenden 1970: 18); 'Forens in een welvartstaat IT' (Testbeeld noor koud klimaat 1966; 20-21)

30 zie bijvoorbeeld 'À la paix comme à la guerre' (Het stnaisvogelnesenval' 1963: 51-53), 'Lintjes voor generaals' (Testbeeld voor koud' klimaat 1966: 18-19) en 'The sickest joke on earth' (Geen bloemen gern bezoek 1968: 28)

31 zie Bert Vanheste, 'Existentialistische literatuur. Een absurd probleem of een niet zo zinvolle oplossing? Litentuar 1992/3, p. 144-150

32 Bet Bos, Literama-interview, uitzending 9 augustus 1971 NCRV. Gepubliceend in Litcruma, 6de jaargang nr. 13, 1971

33 in: De groeten wan andersdenkenden. Amstendam 1970:9 
5. tussen middeleeuwse cholera en zwarte pest

kruistochten brandstapels en later

bij hongersnood oorlog en oorlog

-kleinere oorlogen wel; men stierf

toen hoogstens gespietst geradbraakt

10. overgoten met kokende pek

of ontplofte primitief

met het primitieve buskruit-

was schrijven van poëzie ook al

het onzinnigste dat er bestond

15. in tijden van nood kun je beter

iets anders doen als tenminste

maar iemand me zeggen kon wat

hoewel

in deze tijd net als toen

20. is misschien het schrijven van poëzie

juist daarom het enige dat

je zo nu en dan kunt doen.

Warmond voelt zich als schrijfster opgenomen in het spanningsveld tussen maatschappelijke betrokkenheid en haar schrijverschap. ${ }^{34} \mathrm{Ze}$ mag dan niet in de revolutie geloven, het concept van de persoonlijke revolte spreekt haar wel aan. Warmond is het eens met Camus, dat je moet kiezen voor de slachtoffers. De teneur van de meerderheid in een samenleving is haar antipathiek, omdat die teneur vaak een terreur is. Ze verklaart zich tegen het 'gezetene, gelijkhebbende en gelijk opleggende vooral' ${ }^{35}$ Voor de in 1979 uitgekomen bundel Gesloten spiegels koos Warmond het volgende motto van de negentiende eeuwse filosoof Max Stirner ${ }^{36}$ :

Erst dann, wenn ich Meiner gewiss bin und mich nicht mehr suche, bin ich wahrhaft mein Eigentum: ich habe mich und darum brauche und geniesse ich mich.

34 Ben Bos, 'Gesprek met Ellen Warmond. "Ik wil de mensen met mijn poëzie leren dat ze hun nagels en tanden scherp moeten houden." De Nieuwe Linie 22-11-1969

35 ibidem

36 Max Stirner (1806-1856), pseudoniem van Johann Caspar Schmidt, wordt beschouwd als een voorloper van het anarchisme. Hij vendedigt in zijn boek Der Einzige und sein Eigentum (1845) een absoluut individualisme. Dit individualisme is niet gericht op eigenbelang, maar op het ontwikkelen van een persoonlijke autonomie. 
Möglich dass ich aus mir sehr wenig machen kann, dies wenige ist aber alles und besser als was ich aus mir machen lasse...

Je zou Warmond kunnen karakteriseren als een 'authentieke buitenstaander' in existentialistische zin: iemand die onafhankelijk ten opzichte van door maatschappij of traditie opgelegde normen en waarden wil leven. Die houding neemt ze ook aan ten aanzien van de kunst. Warmond wijst erop, dat kunst zich afzet:

Als poëzie aangemoedigd zou worden, zou zij stikken. Ik zeg dus eigenlijk: tussen de maatschappij en de poëzie bestaat een wrijvingscontact. Het is geen inhaken op, maar een afzetten tegen. ${ }^{37}$

Evenmin als Auden gelooft ze dat je met de pen de maatschappij kunt veranderen, maar dat neemt niet weg dat je je stem moet laten horen. Soms begint verzet eenvoudig met het (durven) denken van een drieletterwoord:

men kan denken: nee

en kan denken:

nhet hieipe je geen donder maar toch

kan denken: nee. ${ }^{38}$

Als je zelfs het 'engagement op papier' achterwege laat, aldus Warmond, maak je vuile handen en is er sprake van kwade trouw. In verschillende interviews met haar komt de uitdrukking 'vuile handen' al dan niet expliciet terug als het gaat over de combinatie dichterschap en engagement:

je kan niet zoveel veranderen in de buitenwereld, je kan hoogstens proberen om je handen zo schoon mogelijk te houden $[\ldots]^{39}$

ten eerste heb ik de behoefte om bepaalde dingen te zeggen en ten tweede speelt op de achtergrond ook een beetje het gevoel dat je vuile handen maakt als je dat niet doet. ${ }^{40}$

De uitdrukking 'vuile handen' is in een existentialistische context vooral bekend van Sartres Les mains sales (1947). Warmond verbindt de term met 'niet handelen' of met ten onrechte je mond houden. Dat geldt eveneens voor Sartre, maar hij geeft er ook nog een andere invulling aan. In zijn toneelstuk behandelt hij de thematiek van

37 Lidy van Marissing, "Ellen Warmond. Doodsbang voor "gevoelspoëzie". In: de Volksknant 16 maart 1968

38 uit: 'Humanisme voor kleinbehuisden'. In: Geen blocmen geen bezoek. Amsterdam 1968: 23

39 in: Ben Bos, Litrenuma 1971/13 (tekst van een radio-uitzending)

40 in: Trudy van Wijk, "'Je wordt wat ouder en wat dommer." Een exclusief interview met Anna Bijns Prijs-winnares Ellen Warmond.' Opzij november 1987 
het politieke handelen. Hoederer, één van de leiders van de Partij van het Proletariaat, valt op een gegeven moment uit tegen zijn secretaris, de intellectueel Hugo:

Wat ben jij erop uit om zuiver te blijven, mijn jongen! Wat ben je bang je handen vuil te maken. Wel, blijf zuiver! Maar wie zal daar wat aan hebben en waarom kom je dan bij ons? Zuiverheid past in het denken van een fakir en van een monnik. Jullie intellectuelen ontlenen er alleen maar het voorwendsel aan om niets te doen. Niets doen, onbeweeglijk blijven, de ellebogen stijf tegen het lichaam, en handschoenen aan. Mijn handen zijn vuil. Tot aan de ellebogen. ${ }^{41}$

Geen stelling nemen is in feite een uiting van mauxaise foi. Hugo wil geen bijdrage leveren aan het gevecht tegen de bezetting van Illyrië, het imaginaire land waar het toneelstuk zich afspeelt. Maar ook door niet te handelen maakt hij 'vuile handen', omdat hij daardoor medeverantwoordelijk is voor de bestaande situatie. Uiteindelijk maakt Hugo ook nog op een andere manier 'vuile handen'; als hij zijn vrouw Jessica in de armen van Hoederer aantreft, trekt hij zijn pistool en schiet hem neer. Niet uit politieke overwegingen, maar uit jaloezie.

Een enkele keer spreekt Warmond zich in interviews uit over haar betrokkenheid bij politieke kwesties, bijvoorbeeld naar aanleiding van de vrijlating van Willy Lages, de Duitse ex-politiechef. ${ }^{42}$ In 1952 al verleende de toenmalige minister Donker hem gratie, maar door een massaal protest van duizenden mensen in Amsterdam en Den Haag werd zijn vrijlating uitgesteld. Telkens als er sprake was van een nieuwe gratieverlening laaiden de discussies weer op over vergelding en berechting. Dat was ook het geval toen Lages in 1966 plotseling vrijkwam, omdat hij ernstig ziek zou zijn en waarschijnlijk binnen drie maanden zou overlijden. ${ }^{43}$ Warmond was een van de ondertekenaars van een petitie tegen vrijlating. Het gedicht 'Adam Kadmon' uit de in 1968 verschenen bundel Geen bloemen geen bezoek draagt als sarcastische ondertitel 'Ziekentroost aan Willy Lages; tevens ter nagedachtenis'. Een fragment hieruit:
21 jaar later moet één
van dezen 'heengaan in vrede
in het aangezicht van de dood'
- de dood gedacht als personage
durft zo'n gezicht niet eens

\footnotetext{
41 Jean-Paul Sartre, Viuile handen. Amsterdam 1965:242

42 Lages, Fischer, Kotalla en Aus der Funten waren de latste Duitse oorlogsmisdadigers die nog in Nederland vastzaten. Ze werden de Vier van Breda genoemd.

43 gegevens ontleend aan: L de Jong. Het koninkrijk der Nederlanden in de Tweede Werldoorlog Deel 12 Epilog ecrste helft. Den Haag 1988: 626 en Kees Schuyt / Ed Taverne, 1950 Wduadrt in zuart-wit. Nederlandse cultuur in Europese context ded IV.Den Hag 2000
} 
recht aan te kijken - of dacht u

van wel? (een vraag aan de minister) ${ }^{44}$

De minister naar wie hier verwezen wordt, is de toenmalige minister van Justitie Samkalden. De vrijlating en de reden die daarvoor werd aangedragen acht Warmond een klap in het gezicht van alle slachtoffers van het Nazidom. In een interview uit 1969 zegt zij hier het volgende over:

Kijk naar Lages; hij is met een feest binnengehaald in zijn geboortedorp. De NPD gebruikt hem als kattevoer; hij was helemaal niet wreed geweest enzovoort enzovoort; het is te gek om bij stil te staan. Verscheidene vrienden van me hebben met moeite Auschwitz overleefd; je zou aan zulke mensen dit wild moeten overleveren. Maar dat heeft ook geen zin, want zij zouden niets doen; zij hebben al moeite genoeg om zich te handhaven in de wereld; ze leven eigenlijk nog steeds in een kampsituatie, zonder familie, zonder idealen van goed en kwaad, voorgoed kapot gemaakt. ${ }^{45}$

\section{Een stuipende pruik van gewichtigheid}

In voorafgaande hoofdstukken zijn al enkele geëngageerde gedichten van Warmond ter sprake gekomen naar aanleiding van de thema's mauvaise foi, geseculariseerde invulling van christelijke begrippen en gender. ${ }^{46}$ In mijn bespreking van existentialistische kenmerken van. Warmonds poëzie komt naar voren, dat het classificatieprocédé minder gauw is aan te treffen in existentialistische poëzie, aangezien het vooral geschikt is voor genres als roman en toneel. Toch komt er een enkele keer in haar poëzie een sjabloonachtige figuur voor als representant van een levenshouding die zij afwijst. Als voorbeeld daarvan citeerde ik in hoofdstuk VI het gedicht 'Leider' uit de bundel De groeten aan andersdenkenden (1970), zonder daar verder op in te gaan. Dat wil ik hier alsnog doen.

\section{Leider}

Hij is.

Hij bewoont een kuras.

$\mathrm{Hij}$ is. Hij beveelt.

44 in: Geen bloemen gien bezock. Amstendam 1968: 34-35

45 Ben Bos, "Gesprek met Ellen Warmond. "Ik wil de mensen met mijn poëzie leren dat ze hun nagels en tanden scherp moeten houden." In: De Nienue Linie 22 november 1969

46 onder andere in hoofdstuk VII en VIII 'Hagepreek' (in: Weersij van een wereld 1957: 12), 'New map of Via Dolorosa I' (in: De groeten aan andersdenkenden 1970) en 'In antwoord op uw schrijven' (in: Gem blocmen geen bezock 1968:22) 
Gooit kastanjes in andermans vuur.

5. Lacht in zijn modderen vuist.

Beveelt.

Hij is een stuipende pruik

van gewichtigheid.

Een buik.

10. Beveelt:

aanstaande lijken in het gelid.

Hij is.

Oogstende hereboer

op andermans dodenakker.

15. Beveelt.

Hand die zich sluit

rond andermans strot.

$\mathrm{Hij}$ is.

Blijvend.

Het gedicht bestaat uit zestien zinnen, verdeeld over zes strofen van wisselende regellengte. De herhaling van de korte, hier en daar elliptische zinnen: 'Hij is' (r. 1, 3, 12, 18) en '(Hij) beveelt' (r. 3, 6, 10, 15) heeft een staccato-achtig effect, dat zo kenmerkend is voor het geven van bevelen. Het is 'een adequaat middel om de leider neer te zetten als een autoritair dictator. Door het herhalingsprocédé lijkt het gedicht op een moderne versie van een oude versvorm als het refrein, waarin de terugkerende regels het thema van het gehele vers bevatten. In dit geval zijn dat de regels: 'hij is' en "(hij) beveelt". Dictators die mensen de dood injagen zijn van alle tijden. Door de afwezigheid van het lidwoord in de titel wordt dit menstype als een abstracte categorie gepresenteerd. Zowel de cyclische opbouw als de presensvorm accentueren hier dat we met een algemene waarheid te maken hebben, die onafhankelijk is van verleden, heden en toekomst.

De wreedheid en onmenselijkheid van de leider geeft Warmond zowel op grammaticaal als op literair niveau vorm. Vanaf r. 6 heeft het woord 'beveelt' geen grammaticaal onderwerp meer. Vanaf dat moment wordt de leider gereduceerd tot de actie die hem het meest karakteriseert: het geven van bevelen. Het is alsof alle menselijkheid nu naar de achtergrond verdwijnt. Iets dergelijks gebeurt in r. 4-6 warin door het ontbreken van het grammaticaal onderwerp op de onmenselijke en ontmenselijkende acties van de leider wordt gefocust.

Ook door gebruik te maken van allerlei literaire technieken weet Warmond de 'leider' meer reliëf te geven. De regel 'Hij bewoont een kuras' ( $r$. 2) roept enerzijds 
het beeld op van een man die voortdurend klaar staat om te strijden, anderzijds het beeld van iemand die zelf afdoende beschermd is tegen het geweld dat hij veroorzaakt. Hij is daar zowel letterlijk als figuurlijk tegen geharnast. De herhaling van het woord 'andermans' in r. 4 ('andermans vuur'), r. 14 ('andermans dodenakker) en r. 17 ('andermans strot') geeft op navrante wijze aan dat alleen ánderen onder zijn acties lijden.

Warmond maakt niet alleen gebruik van het herhalingsprocédé, maar ook van allusies op bekende spreekwoorden, zoals in r. 4 en 5 . De regel 'Gooit kastanjes in andermans vuur' (r. 4) is een allusie op het spreekwoord: 'iemand de kastanjes uit het vuur laten halen' ofwel iemand iets gevaarlijks laten doen, terwijl men er alleen zelf voordeel van heeft. Regel 4 zou je aan kunnen vullen met de woorden: 'en laat anderen ze eruit halen'. De leider veroorzaakt door zijn zucht naar geweld problemen die hij anderen, soldaten bijvoorbeeld, laat oplossen. Dat ze dat met de dood moeten bekopen, deert hem niet. De vierde regel verwijst als het ware al vooruit naar regel 10: 'aanstaande lijken in het gelid'.

De volgende regel geeft aan, dat dit leidertype niet alleen onverschillig staat tegenover wat hij aanricht, maar er ook nog een zeker genoegen in schept: hij 'Lacht in zijn modderen vuist' (r. 5). Ook deze regel bevat een allusie op een bekende uitdrukking: 'in zijn vuistje lachen'. De leider lijkt zich niet alleen in stilte te verheugen over zijn behaalde successen, maar ook over andermans ongeluk. Is hier sprake van leedvermaak? Er staat echter niet dat hij in zijn vuistje lacht, maar 'in zijn modderen vuist'. 'Modderen' betekent 'modderig', 'van aarde' of 'tot de aarde behorend". Verwijst ook deze regel vooruit naar de dodenakker in r. 14? Kleeft de aarde van de dodenakker aan zijn handen? Zo opgevat klinkt hier ook de uitdrukking 'vuile handen' in door, maar dan niet in Sartriaanse zin. In Les mains sales van Sartre wordt de uitdrukking op twee manieren gebruikt. Ten eerste betekent. 'vuile handen' maken, dat je je soms moet corrumperen om iets te bereiken wat in essentie goed is. Ten tweede maak je ook vuile handen, juist door de dingen na te laten die je eigenlijk vanuit morele overwegingen zou moeten doen. Warmond gebruikt de uitdrukking 'vuile handen' in haar werk vooral in die laatste betekenis. ${ }^{47}$ In dit gedicht echter betekent de allusie 'modderen vuist' dat de leider zich zowel letterlijk als figuurlijk schuldig maakt aan zaken die in moreel opzicht niet verdedigbaar zijn.

In de derde strofe wordt de leider gepresenteerd als een toonbeeld van arrogantie. Het 'tegenwoordig deelwoord 'stuipende' (r. 7) is afgeleid van het werkwoord 'stuipen', dat 'voorover hellen' of 'bukken' betekent. Zo opgevat roept de regel 'een stuipende pruik van gewichtigheid' (r. 7) het beeld op van iemand die haast bezwijkt onder zijn eigen gewichtigheid, zo belangrijk vindt hij zichzelf. In vroeger tijden was de pruik een teken van waardigheid en status, maar tegenwoordig is de pruik toch vooral een attribuut dat de indruk moet wekken dat er iets is wat er eigenlijk niet meer is. In die zin symboliseert de pruik hier de schijn: het lijkt heel

47 zie ook paragraaf 4 van dit hoofdstuk 
wat, maar wat eronder zit stelt niets voor. Dit wordt geaccentueerd door het enjambement in r. 7-8 waardoor het volle accent op 'pruik' komt te liggen. De negende regel ('Een buik') veroorzaakt een ironische verschuiving in de betekenis van het woord 'gewichtigheid': de leider wordt hiermee gereduceerd tot een volgevreten arrogante ijdeltuit. De assonantie in deze strofe trekt de kenmerkende facetten daarvan bij elkaar: 'stuipende', 'pruik' en 'buik'.

Warmond mag graag de arrogantie van de macht bespotten. In onderstaand fragment van het gedicht 'À la paix comme à la guerre II' relativeert zij de status van de machthebber door hem een 'hobbelpaard' te laten berijden in plaats van een mooi volbloed exemplaar, waarmee leiders in vroegere tijden vaak in de beeldende kunst werden afgebeeld. In het woord 'hobbelpaard' kun je ook een allusie lezen op de uitdrukking 'zijn stokpaardje berijden'. Op die manier wordt aangegeven dat de keizer uit het gedicht ook plezier beleeft aan zijn verwoestende activiteiten:

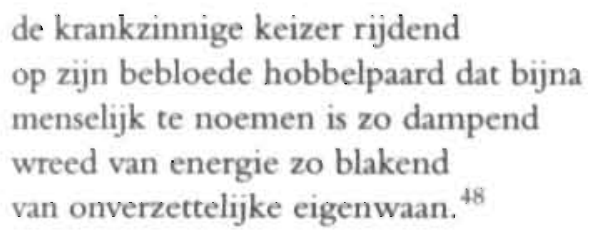

Terug naar het gedicht 'Leider'. De vierde strofe onthult wat de leider beveelt en wat de gevolgen van dat bevel zijn. De regel 'aanstaande lijken in het gelid' (r. 11) roept niet alleen het beeld op van een aaneengesloten rij militairen die zich hebben onderworpen aan het gezag van de leider, maar verwijst tegelijkertijd vooruit naar hun toekomst: de militaire begraafplaats, waar de doden in lange rijen naast en achter elkaar liggen.

In r. 13-14 wordt de leider voorgesteld als een rijke landbouwer die anderen voor zich laat werken en daar rijkelijk van profiteert. Het enjambement in r. 13-14 accentueert het navrante contrast tussen 'hereboer' enerzijds en 'dodenakker' anderzijds. De woorden 'oogsten' en 'akker' roepen allereerst associaties op van zaaien en het oogsten van voedzame gewassen, maar het enige wat de leider gezaaid én geoogst heeft is dood en verderf op grote schaal.

Evenals de vierde strofe bevat het begin van de laatste een macaber beeld, dat een inhoudelijke variatie is op de beelden in r. 11-14: 'Hand die zich sluit / rond andermans strot'. Het enjambement in r. 11-12 richt alle aandacht op het woord 'sluit', dat hier een proces van toenemende kracht of druk aangeeft. Uiteindelijk zal ook deze wurgende greep tot de dood van het slachtoffer leiden. In het gedicht 'De leider spreekt' omschrijft Warmond dit soort leiders op aforistische wijze als volgt:

48 in: Het stmiswogelresenvaat. Amsterdam 1963:52 
Een generaal lijdt aan een ziekte

waar meestal anderen aan sterven ${ }^{49}$

In muzikaal opzicht heeft het gedicht 'Leider' wel iets van een rondo, een muziekstuk waarin het hoofdthema onder afwisselende en verschillende modulaties telkens als refrein terugkeert. Het hoofdthema ('hij is' / 'hij beveelt') wordt in de loop van het gedicht telkens op een andere manier gespecificeerd, met name in de tweede, derde, vierde en zesde strofe om uiteindelijk weer terug te keren bij het begin: 'Hij is.' Mocht je als lezer op dat moment nog de illusie hebben dat het misschien ooit zou kunnen veranderen, dan boort Warmond die hoop definitief de grond in met de laatste zin: hij is namelijk 'Blijvend'.

\section{Besluit}

Warmond is een van de weinige schrijvers in Nederland die zich niet afzijdig hebben gehouden van direct geëngageerde literatuur. Naast de melancholieke Warmond bestaat er ook een strijdbare Warmond, die zich bewust is van haar maatschappelijke verantwoordelijkheid als schrijver, zoals blijkt uit diverse geëngageerde gedichten en interviewfragmenten. Hoewel' ze in een interview erkem; dar laar sociaal-politick engagement groter is geworden, ${ }^{50}$ is dit element ook in haar werk. van vóór 1970 al aanwezig. Hejet engagement van Warmond betekent geen breuk in. de existentialistische thematiek, het maakte daar al eerder deel van uit. Hoogstens heeft het later wat meer accent gekregen.

In zijn studie over de Vijftiger Jan G. Elburg poneert Peter Bormans de interessante stelling, dat politiek engagement een vorm van transcendentie is. Iemand die politiek geëngageerd is, richt zich immers op een 'hoger' doel, bijvoorbeeld het dichterbij brengen van een betere maatschappij. ${ }^{51}$ Dat geldt in zekere mate ook voor Warmond. Al is ze sceptisch over de macht en de invloed van de dichter, het feit dát zij dingen aanklaagt, geeft aan dat ze een ideaalbeeld heeft. Uit haar werk spreekt een verlangen naar een samenleving van autonoom denkende mensen die zich binnen bepaalde grenzen verantwoordelijk weten voor hun eigen daden en respect hebben voor elkaar.

Volgens Bormans werd transcendentie ten onrechte eeuwenlang alleen mogelijk geacht binnen een godsdienstige context. Bij de Vijftigers is weliswaar vaak sprake van religiositeit en mystiek, maar die hoeven niet samen te gaan met godsdienstigheid of kerkelijkheid. Ook dat geldt voor Warmond. De volgende hoofdstukken gaan daar uitgebreid op in.

49 in: Gern blocmen gern bezuek. Amsterdam 1968: 38

50 Ben Bos 1969

51. Peter Bormans, "Ik hoop dat ik stoor". De poezzic uan Jan G. Elburg (1919-1992). Boek 1. Brussel z.j." $346-352$ 


\section{VOOR WIE UIT IS OP INKEER}

\section{Inleiding}

Eén van de thema's die in het werk van Warmond steeds naar voren springen is het verlangen te ontsnappen aan een inperkende en beperkende rationaliteit. Dat geldt zowel voor haar proza als voor haar poëzie. Alleen door te ontsnappen aan een controlerend, reflexief bewustzijn is een spontane, pre-reflexieve lichaamsbeleving mogelijk. Dualisme, de scheiding tussen subject en wereld enerzijds en de scheiding tussen reflexief ik en lichaam anderzijds, maakt plaats voor een unificerende werkelijkheidservaring. In de roman Paspoort voor miemandsland staat de uitdrukking 'chinese momenten' voor een loskomen van tijd en ruimte tijdens de sexuele ontmoeting. Er gaat een transformerende werking van uit: na afloop is het contact met het leven weer (even) hersteld, de hoofdpersoon voelt zich als herboren. In haar poëzie gebruikt Warmond allerlei literaire middelen om de pre-reflexieve ervaring op te roepen: infinitiefconstructies waarin het subject afwezig is ('de hand laten grijpen / niet tasten'), beelden voor het pre-verbale ('ongeletterde tanden') en signaalwoorden als eenvoudig, vanzelfsprekend, probleemloos, zorgeloos, natuurlijk, onvatbaar, terugkeer en oorsprong. ${ }^{1}$

In hoofdstuk VI merkte ik op, dat dit alles dicht in de buurt van boeddhistische ideeën komt. Volgens het boeddhisme is een non-dualistische beleving van het zijn mogelijk door het ego te transcenderen. Dat geldt overigens niet alleen voor het boeddhisme, maar ook voor andere contemplatieve tradities. Het is in dit verband belangrijk om te weten, dat in de boeddhistische en christelijke mystiek ego iets anders betekent dan in de westerse psychologie. Het verwijst niet naar wat het persoonlijk voornaamwoord 'ik' aanduidt. Het loslaten van het ego in mystieke zin betekent niet dat we onze persoonlijkheid moeten opgeven. Dat zou niet eens kunnen, aangezien onze persoonlijkheid het materiaal van ons individuele bestaan is. Maar we kunnen met dat materiaal op twee manieren omgaan: op een egocentrische of op een niet-egocentrische manier. In de psychologie heeft het begrip 'ego' een positieve betekenis: om goed te kunnen functioneren is een stevig ego vereist. De term verwijst naar een zeker vertrouwen of zelfvertrouwen, het gevoel dat we ons niet voor ons bestaan hoeven te verontschuldigen. In de contemplatieve tradities echter wordt met 'ego' iets anders bedoeld, namelijk het egocentrisch perspectief. Dit egocentrisch perspectief moet getranscendeerd of losgelaten worden om een unificerende werkelijkheidsbeleving mogelijk te maken. ${ }^{2}$

Tot nu toe heb ik voor de eerder genoemde ervaringen de existentiële fenomenologie en het daarop gebaseerde existentialisme als interpretatiekader gebruikt. Maar

I zie hoofdstuk VII

2 zie: Han $\mathrm{E}$ de Wit, De verbongen bloei. Over de psychologische achtengronden van spiritualiteit. Kampen $1998^{8}: 67-68$ 
verlangen naar eenheid, het loskomen van tijd en ruimte, transformatie, een ander bewustzijn en beelden voor het pre-verbale doen ook aan mystiek denken. Het kan daarom op basis van deze gegevens interessant zijn om bepaalde gedichten van Warmond in een mystiek interpretatiekader te plaatsen, omdat dit een ander licht kan werpen op haar werk, met name op haar poëzie. Maaike Meijer heeft erop gewezen dat binnen de neerlandistiek de belangstelling voor poëtica en mystiek zich vooral richt op moderne mannelijke dichters als Lucebert, Kouwenaar, Dèr Mouw, Van Ostaijen, A. Roland Holst en Gilliams. In haar boek. De lust tot lezen (1988) doorbreekt zij deze tendens door als eerste het werk van een moderne vrouwelijke dichter, Vasalis, vanuit een mystiek interpretatiekader te bestuderen. Het wordt tijd dat Vasalis gezelschap krijgt.

Van der Vegt (1981) wees al op het 'oosterse' stiltethema in het werk van Warmond, dat met name in haar latere werk wat pregnanter naar voren komt. ${ }^{3}$ In haar vroegere werk komt het ook al voor, maar daar wordt het nog met enige ironische afstand gepresenteerd, zoals in het openingsgedicht van Naar men zegt (1955):

Naar men zegt is dit

het leven der wijzen:

niet meer bewegen stilstaan als een berg ${ }^{4}$

Uit Warmonds werk blijkt, dat zij dit stilte-ideaal onbereikbaar acht, aldus Van der Vegt. Bij de bespreking van zijn artikel liet ik mijn twijfels over deze uitspraak blijken. In het gedicht 'Voor wie uit is op inkeer 2', waar ik straks uitgebreider op inga, staat immers dat dit ideaal 'welhaast niet haalbaar' is. Het woord 'welhaast' is intrigerend: het geeft aan dat realisering van dit ideaal niet geheel en al onmogelijk moet worden geacht. Er wordt een zekere ruimte opengelaten. Weliswaar miniem, maar voldoende om in de komende hoofdstukken op zoek te gaan naar antwoorden op de volgende vragen:

welke factoren verstoren de realisering van het verlangen naar stilte en eenheid? zijn er in het werk van Warmond gedichten te vinden waarin dat verlangen wél gerealiseerd wordt?

zo ja, met welk soort mystiek hebben we dan te maken?

sluiten dit mystieke verlangen en het aards gerichte existentialisme elkaar uit?

\section{Mystiek}

Er zijn grote overeenkomsten in mystieke ervaringen, die bijna geheel onafhankelijk zijn van plaats, tijd, cultuur en religieuze of levensbeschouwelijke

3 Jan van der Vegt, 'Kijken in een gesloten spiegel.' In: Ons ofdeel 1981, afl. 5. p. 655-664

4 in: Naar men zegt. Den Haag 1955: 7 
opvattingen. Dat betekent niet, dat er geen variaties zijn. Juist door deze variaties. ontstaan verschillende tendensen en tradities, mede door de verschillende antwoorden op de vraag waar de ervaring vandaan komt en waar ze naar verwijst. Volgens de Engelse onderzoeker F.C. Happold zijn mystieke ervaringen niet alleen in een religieuze context te plaatsen. Ze vormen onder andere ook een inspiratiebron voor de kunsten:

mysticism has its fount in what is the raw material of all religion and is also the inspiration of much of philosophy, poetry, art, and music, a consciousness of a beyond $[\ldots]^{5}$

Het verband tussen poëzie en mystiek speelt in het werk van moderne dichters als Baudelaire, Mallarmé, Van Ostaijen en Nijhoff een grote rol. Voor hen is poëzie zélf een vorm van mystiek. Hugo Friedrich (1956/1988) spreekt in dit verband van 'lecre Idealität' of 'lege transcendentie', omdat de ervaring van het 'andere' niet wordt ingevuld met theologische begrippen als God of de Almachtige. Veel mystici willen een bepaald doel bereiken, aldus Friedrich, maar bij dichters als Baudelaire, Rimbaud en Mallarmé ontbreekt deze wil. Het doel wordt ervaren als ver en leeg. het Absolute als inhoudsloos. Friedrich vindt het begrijpelijk dat de poètes maudits die nog vastzaten aan een coherent wereldbeeld het gevoel hadden tegenover het Niets te staan. ${ }^{6}$

Het is de vraag of de poëzie=mystiek-opvatting bepalend is voor álle moderne poëzie of alleen voor de zogenaamde pure traditie, een term die in Nederland geïntroduceerd is door Sötemann. ${ }^{7}$ Voor de 'puce' of 'zuivere' dichter is de poëzie een instrument waarmee de onbekende essentie van het bestaan verkend kan worden. De 'zuivere' dichter hoopt, dat het instrument - het voltooide gedicht- het mysterie zelf zal belichamen en tot uitdrukking zal brengen. In hoofdstuk XI ga ik hier naar aanleiding, van enkele gedichten van Ellen Warmond verder op in.

Friedrich spreekt van 'lege' transcendentie, omdat ze niet wordt ingevuld met het traditionele godsbeeld. Maar geldt dat ook niet voor veel mystici uit diverse perioden en tradities, zowel christelijk als niet-christelijk, die het goddelijke niet of niet meer invullen met allerlei beelden en namen? De opvatting dat mystiek niets te maken heeft met, een god is niet revolutionair. Uit onderzoek blijkt, dat de zogenaamde 'volle' transcendentie slechts een bepaalde vorm van mystiek is. Bovendien is ze zeker niet de meest verbreide en misschien niet eens de belangrijkste vorm. Bepaalde onderzoekers beschouwen haar zelfs als een lager of minder belangrijk

5 F.C. Happold, Mysticism. A Study and an Anthology. Londen 1990. (tweede herziene druk): 18-19

6 Hugo Friedrich, Die Struktur der modernen Lyrik. Von der Mitte des neunzehnten bis zur Mitte des zwanzigsten Jahrhunderts. Hamburg 1956/1988: 48

7 A.L. Sötemann, Over poética en poézie. Groningen 1985 
stadium dan de zogenaamde lege transcendentie. De laatste is de metafoor en allerlei andere beelden immers voorbij. ${ }^{8}$

De geestelijke achtergrond van de huidige moderne dichtkunst wordt gewoonlijk gezocht in de tweede helft van de achttiende eeuw. Meestal wijst men dan in navolging van Friedrich op de breuk met de voorafgaande rationalistische eeuw. De exploratie van het onderbewuste en de worsteling met de taal, die zichtbaar wordt in allerlei taalexperimenten, zijn weliswaar opvallende kenmerken, maar dit zijn slechts 'moderne' verschijningsvormen van een al eeuwenoude opvatting, aldus Gerard Aertsens in zijn artikel 'Het eeuwenoude dualisme in de Nederlandse experimentele poëzie'. ${ }^{9}$ Hij duidt op levensbeschouwingen waarin de wereldschepping door het woord een belangrijke rol speelt. Dit denkbeeld heeft de mythische of vóórmythische wereldopvatting van de Oudheid beheerst. Deze prelogische denkwereld heeft, aldus Aertsens, in Egypte haar duidelijkste vorm van expressie gevonden. Hij wijst erop, dat Rodenko bijvoorbeeld uitvoerig de middelaarsrol van het woord in de oud-Egyptische denkvormen heeft belicht in verband met de poëzie van Achterberg. Een recentere studie van Anja de Feijter (1994) heeft aannemelijk gemaakt, dat ook Luceberts poëzie geïnspireerd is door oude teksten waarin het woord als scheppende kracht wordt genoemd, met name door het. Sefer Jetsira. Dit is een kabbalistisch geschrift, gedateerd tussen de derde en zesde eeuw na Christus, waarin gesteld wordt dat God de wereld schiep door middel van de tien sefirot (getallen) en de 22 letters van het Hebreeuwse alfabet. Al wat bestaat kwam met name tot stand door allerlei combinaties van de 22 letters. ${ }^{10}$. Friedrich heeft overigens ook zelf gewezen op de veel oudere achtergronden van de moderne poëzie:

Die Erkenntnis von der Verwandtschaft zwischen Poesie und Magie ist zwar uralt. Doch musste sie neu erworben werden, nachdem Humanismus und transalpiner Klassizismus sie verschüttet hatten. ${ }^{11}$

Mystieke ervaringen zijn door de eeuwen heen op schrift gesteld. De verhevenheid van het onderwerp en de bijzondere uitdrukkingsvormen maakten dat geschreven mystiek in het verleden bijna automatisch tot de literatuur werd gerekend, aldus Van de Watering (1979) ${ }^{12}$ Hij stelt voor mystiek op te vatten als een speciaal genre, omdat mystieke geschriften dwars door alle culturen en tijden heen grote overeenkomsten vertonen in woordenschat, beeldgebruik, voorstellingen en proce-

8 zie bijvoorbeeld Frits Staal. Het wetenschappelijk onderzock nan de mystick. Utrecht/Antwerpen 1978

9 in: De VTaamsche Gids september 1960:534-540

10 Anja de Feijter, 'apocrief/de analphabetische naam'. Het historisch debuut van Lucebert in het licht um de intertelest nun Joodse mystick en Holderlin. Amstendam 1994

11 Hugo Friedrich 1956/1988: 50

12 C.W. van de Watering. Met de ogen dicht. Een interpretatic nam enkele gedichten uan Lucebert als torgang rof diens poìzie en portica. Muiderberg 1979: 79-90 
dures. In zijn studie Met de ogen dicht (1979) fungeert de mystiek als interpretatiekader voor een aantal gedichten van Lucebert. Van de Watering stelt voor mystiek als literair genre zowel inhoudelijk als formeel/literair te definiëren. Allereerst de inhoudelijke component. De mystieke ervaring is een bewustzijnstoestand of geestelijke staat die zich van andere bewustzijnstoestanden onderscheidt door een aantal kenmerkende eigenschappen:

1. het ervaren van eenheid of een-wording. Deze ervaring kan afhankelijk van iemands achtergrond geïnterpreteerd worden als een-wording met een persoonlijke God, het onpersoonlijk goddelijke, het absolute, het levensbeginsel zelf, het universum, de natuur, het diepste eigen ik of zelf, het onbekende, het andere of het niets

2. de ervaring heeft een ken-aspect: er wordt kennis verworven van of inzicht ervaren in een vorm van waarheid die van een andere orde is dan die verkregen wordt via het logische denken

3. passiviteit: je kunt de ervaring niet afdwingen, ze overkomt je ervaren van tijdloosheid

4. een ik-bewustzijn dat uitgaat boven en buiten het gewone, alledaagse ik

5. de ervaring geldt als onuitsprekelijk of onmededeelbaar, omdat ze niet in rationele bewoordingen is uit te drukken

Van de Watering noemt vervolgens nog drie kenmerken: de lichtervaring, de angstervaring en depressie na de extase. Deze kenmerken neemt hij niet op in de basisomschrijving, omdat het niet duidelijk is of ze essentieel zijn voor de mystieke ervaring.

De formele/literaire component zou idealiter én lexicon moeten zijn van het taaleigen van mystici. Om van mystiek te spreken moet er aan twee voorwaarden worden voldaan. De auteur moet gebruik maken van het taaleigen van mystici zoals dat in het lexicon beschreven staat. Bovendien moet er sprake zijn van een ervaring, zoals beschreven in de inhoudelijke component. Helaas bestaat voornoemd lexicon nog niet. Eerst moeten er allerlei deelstudies komen over afzonderlijke woorden en/of auteurs. In hoofdstuk XI, waarin Van de Waterings analyseschema wordt toegepast, lever ik een bijdrage aan dit lexicon.

Van de Watering wijst er terecht op, dat werken met parallelplaatsen uit werken van erkend mystieke auteurs problematische kanten heeft. De indruk kan namelijk ontstaan, dat er sprake is van ontlening of van een soortgelijke spirituele traditic als van de mystici naar wie verwezen wordt. Er kan immers ook sprake zijn van eigen, spontane woorden en beelden of van een tussenvorm of mengverhouding. Parellelplaatsen dienen daarom alleen als illustratie, niet als argument.

Hoewel ik het in grote lijnen eens ben met Van de Watering en zijn aanpak inspirerend vind, wil ik toch een paar kanttekeningen plaatsen bij. een aantal van zijn opmerkingen over mystiek. De eerste kanttekening betreft de uitspraak, dat de 
mystieke 'procedure' gekenmerkt wordt door een hoge inzet: de mysticus wil het: uiterste, hij eist het onmogelijke, maar hij krijgt altijd minder dan hij wenst. Het echec, de ontgoocheling, zou een vast bestanddeel zijn van de mystieke ervaring. Dit conflictmodel behoeft mijns inziens enige nuancering. De grondtoon van de mystieke ervaring is altijd een vorm van verzoening. De kern van de mystieke ervaring is immers het ervaren van eenheid. De ontgoocheling wordt eerder veroorzaakt door het feit, dat de ervaring vaak van korte duur is. Bovendien kan de mysticus intens terugverlangen naar deze eenheidsbeleving, omdat het verschil met. de 'gewone' werkelijkheid daarna des te scherper gevoeld wordt. In diverse mystieke tradities wordt er echter op gewezen dat de mysticus hier niet in moet blijven hangen. Terugkeer naar de 'gewone' werkelijkheid is juist wenselijk. De mystieke ervaring is namelijk niet het einddoel. De volgroeide mysticus is volgens het ideaal van de middeleeuwse mysticus Ruusbroec (1293-1381) iemand die door de mystieke ervaring zodanig getransformeerd is, dat het 'schouwen' al zijn daden zal doordringen. Dit is het hoogste stadium. ${ }^{13}$ Waarschijnlijk is hij hierin beinvloed door Meester Eckhart (ca. 1269-1327). Diens visie blijkt uit een. interessante interpretatie van het nieuwtestamentische verhaal van Maria en Martha. In Lucas 10, 38-42 wordt verteld dat Jezus uitgenodigd wordt in het huis van Marta. Terwijl haar zuster Maria naar hem luistert, is Marta bezig met bedienen. Op een gegeven. moment komt ze erbij staan en zegt: 'Heer, laat het U onverschillig, dat mijn zuster mij alleen laat bedienen? Zeg haar dan dat ze mij moet helpen.' Het antwoord luidt, dat Maria het beste deel heeft gekozen. Eckhart legt deze passage op een tegendraadse manier uit. Volgens hem is Maria nog niet toe aan de hoogste vorm van mystiek, waarbij de mystieke ervaring uiteindelijk ook in het dagelijkse doen is doorgedrongen. ${ }^{14}$

Ook voor de boeddhist is de mystieke ervaring geen doel op zich. De wijsheid die men op de berg verkregen heeft, moet haar toepassing vinden in de wereld, zo luidt een bekende boeddhistische uitspraak. De afdaling noemt men het pad van het mededogen of van de liefde.

Van de Waterings opmerking dat de mysticus altijd minder krijgt dan hij wenst, gaat misschien wel op voor dichters voor wie dichten gelijkstaat aan mystiek. Rodenko spreekt in dit verband weliswaar over de poëzie van het echec, maar dat wil niet zeggen dat de dichter zich ontgoocheld of mislukt voelt. Het gedicht is voor de moderne dichter geen openbaring vanuit het transcendente (God of Muze), maar een zesde zintuig waarmee hij tekens uit het Andere kan opvangen. Het blijft echter mensenwerk. Het lijkt of het Andere door een heel dun vliesje van de werkelijkheid gescheiden is, voorbij dit vlies kan de dichter niet. Dat is zijn echec.

13 zie: Paul Mommaers en Jan van Bragt, Ruusbroec in gesprek met het Oosten. Mystiek in boeddhisme on christendom. Kampen 1995: 222-224

14 zie Bruno Borchert, Mystick. Het verschijnsel, de geschiedenis, de nicuse uitdaging. Haarlem 1994 (tweede, bijgewerkte druk): 124 
Maar het vlies tastbaar maken, er een zekere transparantie aan geven en, al is het maar voor even, deel aan dat Andere hebben, dat is de uiterste triomf of genade van de dichter van het echec, aldus Rodenko. ${ }^{15}$

De tweede kanttekening betreft een opmerking over Meester Eckhart. Van de Watering stelt terecht, dat ook in de westerse traditie de koppeling van mystick aan een vaste godsvoorstelling discutabel is. Hij noemt als voorbeeld de middeleeuwse mysticus Meester Eckhart, die via een god-ontstijgende uiteindelijk bij een god-ontkennende mystiek zou zijn uitgekomen. ${ }^{16}$ Hoewel Van de Watering hier verder niet op ingaat, lijkt het alsof Eckhart tenslotte bij een atheistische levensvisie is uitgekomen. Zijn uitspraken over het 'Naamloos Niets', 'Onbeweeglijke Rust' en dergelijke horen echter thuis in een oude mystieke traditie, de zogenaamde via negativa. Het idee dat het goddelijke alleen in negatieve termen beschreven kan worden is vanuit India ook de christelijke mystiek binnengekomen. Een negatieve omschrijving bevestigt juist de grootsheid van het goddelijke. ${ }^{17}$ In deze traditie is het belangrijk dat je je losmaakt van allerlei beelden, concepten en vooronderstellingen. Boeddhisten noemen dit bevrijd zijn van beelden en dergelijke de Leegte of het Niets. Dit is niet nihilistisch bedoeld. Het duidt eerder op een open bewustzijn, het onderscheid aanbrengende denken voorbij. In deze beeldloosheid verdwijnen alle goddelijke namen en al het onderscheid.

\section{De mijnschacht van de eigen geest}

Verlangen naar stilte en eenheid zijn terugkerende thema's in het werk van Warmond, zoals in de inleiding al naar voren kwam. Er zijn echter factoren die de realisering van dit verlangen belemmeren of bemoeilijken. Het tweedelige gedicht 'Voor wie uit is op inkeer' uit de bundel Uitzicht op inzicht (Amsterdam 1974:39-40) geeft aan welke factoren dat kunnen zijn:

15 Paul Rodenko, 'De poèzie van het 'vlies'. In: Verzamelde essays en kritieken, deel II. Amstendam 1991: 249-260

16 Van de Watering 1987:81

17 zie: S. Radhakrishnan, Eastern Religions and Wotem Thought. Oxford 1939: 292 en Bruno Borchert 1994: 19 


\section{VOOR WIE UIT IS OP INKEER}

1

Voor de afdaling in de mijnschacht van de eigen geest is bijna geen zwarte makker meer te vinden een witte nog minder als die tenminste

5.binnen ons zelf geboren hoort te zijn

want wat hoor je dan in de lift die rinkelend op weg is naar de inkeer: kirren kwebbelen en keuvelen een kwekkende bes in gesprek 10. met een verkalkte bastaard.

\section{2}

Het oog op de Himalaya of willekeurig welke bergtop laten rusten en dan bedoel ik ook: rusten

zodat geen wimper meer fladdert

5. en geen gedachtestolsel knapt onder de vuile nagel der versterving

mooi moet dat zijn maar hier ter plaatse welhaast niet haalbaar

door iedere gedachte aan niets

10. rijdt met knersende remmen een tram.

Het gedicht bestaat uit twee op analoge wijze opgebouwde delen. Eerst wordt een mogenjkheiơ tot inkeer genoemơ: in đee f is đat đe arââing in đe munschacht, het liefst in aanwezigheid van een zwarte én een witte makker; in deel 2 is dat 'Het oog op de Himalaya / of willekeurig welke bergtop laten rusten'. Vervolgens geeft het lyrisch subject een nuancering aan: in deel 1 zijn de regels 'als die tenminste / binnen ons zelf geboren hoort te zijn' een nuancering bij 'witte makker'; in deel 2 wordt het begrip 'rusten' nader gepreciseerd: 'zodat geen wimper meer fladdert / en geen gedachtestolsel knapt / onder de vuile nagel der versterving'. Beide delen eindigen met geluiden die de realisering van het verlangen naar verdieping en rust verstoren.

Bij eerste lezing lijkt de interpretatie van dit gedicht geen problemen op te leveren, maar bij nader inzien roepen de beelden die Warmond gebruikt de nodige vragen op: wie of wat zijn die zwarte en witte makkers en wat is hun taak? Wat doen de 'kwekkende bes' en de 'verkalkte bastaard' in de lift?

'Voor wie uit is op inkeer' is gebouwd op een antithese: de weg omlaag (deel 1) en de weg omhoog (deel 2) ofwel katabasis en anabasis. Katabasis is de weg omlaag naar het duistere onbewuste, terwijl anabasis de weg omhoog is uit het onbewuste naar het heldere bewustzijn. Een van de bekendste voorbeelden van dit motief is de mythe van Orpheus en Eurydice. Ook het lyrisch subject uit 'Voor wie uit is op inkeer 1' daalt af, hij wil de diepte in. De geest als mijnschacht is een interessant beeld. De mijnschacht is een verbinding tussen boven en beneden, tussen bovenwereld en de onderaardse wereld van de mijn. Het beeld geeft aan dat er via de geest toegang mogelijk is tot een nog niet of slechts gedeeltelijk geëxploreerd gebied ofwel -in metaforische zin- de eigenlijke mijn. Dit beeld roept uitdrukkingen op 
als 'diepgravend', 'de diepte ingaan' en 'naar iẹts graven', uitdrukkingen die allemaal in oppositie staan met een sfeer van oppervlakkigheid. Je zou de mijnschacht in dit gedicht op kunnen vatten als een visualisering van (het verlangen naar) geestelijke verdieping of diepgang.

Voor de 'afdaling in de mijnschacht van de eigen geest' is het wenselijk dat het lyrisch subject vergezeld wordt door een zwarte en/of een witte makker. Als die er niet zijn ('want wat hoor je dan' r. 5), krijg je in plaats van de gewenste diepgang alleen maar oppervlakkig gepraat, afkomstig van twee 'begeleiders' ('een kwekkende bes' en 'een verkalkte bastaard') van wie ook nog weinig werkkracht is te verwachten. Het bijwoord 'dan' zou hier ook nog een emotionele betekenis kunnen hebben en wel die van ergernis. Zo opgevat accentueert 'dan' het ergerniswekkende en het ongewenste van de lawaaiige situatie.

Wie zijn toch die zwarte en witte makker? Rodenko heeft erop gewezen, dat het dier, het kind, de neger, de misdadiger en de krankzinnige een grote rol spelen in de moderne poëzie. ${ }^{18} \mathrm{Hij}$ geeft onder meer de volgende voorbeelden: 'Je suis une bête, un nègre' van Rimbaud en ' $\mathrm{Er}$ is een grote norse neger in mij neergedaald' van Lucebert. De 'neger' representeert hier de instincten, de ongecensureerde driften en de duistere impulsen uit het onbewuste, aldus. Rodenko. In De lust tot lezen stelt Meijer dat dit soort interpretaties discutabel zijn. ${ }^{19}$ Het woord 'neger' is besmet geraakt, omdat het mede door zijn koloniale context een raciale bijklank heeft gekregen. Zij stelt dat witten in de loop der geschiedenis van zwarten een projectiescherm hebben gemaakt van hun eigen angsten en ongewenste gevoelens. Is dat ook het geval met de 'zwarte makker' in 'Voor wie uit is op inkeer'?

Gezien de context van de mijn lijken zwart en wit me in dit gedicht geen raciale aanduidingen. Het ligt voor de hand hier allereerst aan mijnwerkers te denken. Wat hen verbindt, is de kameraadschap met degenie die afdaalt, het lyrisch subject. De term 'makker' geeft geen hiërarchische verhouding aan, maar duidt juist op gelijkwaardigheid. De zwarte makker in dit gedicht doet denken aan een geroutineerde mijnwerker, iemand die al zo vaak in de mijn geweest is, dat het vuil in al zijn poriën is gaan zitten. De witte makker verbaast echter in deze context: is hij een mijnwerker die zich schoon heeft gemaakt of iemand die nog niet eerder mijnarbeid heeft verricht en dus voor het eerst naar beneden gaat? De passage 'als die tenminste / binnen ons zelf geboren hoort te zijn' (r.3-4) geeft aan dat de 'witte makker' uit onszelf dient voort te komen. Geven deze raadselachtige regels aan, dat de afdaling op eigen verantwoording geschiedt, dat wil zeggen een eigen keuze is, zonder druk van buitenaf? De 'witte makker' zou kunnen duiden op een zekere natuurlijke onbevangenheid, die echter door alle opgedane ervaringen moeilijk

18 Paul Rodenko, 'De experimentele explosic in Nederland. Context en achtergronden.' In: Verzamelde essays en kriticken, deel II. Amsterdam 1991:352-434

19 Maxike Meijer, De lust tot lezen. Nederlandse dichteressen en het litenaire systeem. Amsterdam 1988: $217-218$ 
bereikbaar is. Zo opgevat, staat de zwarte mijnwerker voor de opgedane ervaring en de witte voor de onbevangenheid. Voor het lyrisch subject zijn beide facetten belangrijk: om tot geestelijke diepgang te kunnen komen maakt het lyrisch subject gebruik van de opgedane ervaringen. Tegelijkertijd is daarbij ook een zekere onbevangenheid en openheid wenselijk, anders ziet hij misschien alleen maar het meest voor de hand liggende.

In plaats van deze gewenste en geschikte maten zit er een onbruikbaar gezelschap in de lift. Hun gesteldheid doet het ergste vermoeden: de bes is oud en kletst zonder enige inhoud. De woorden waarin de k-klanken zo opvallen ('kirren', 'kwebbelen', 'keuvelen', 'kwekkende', 'verkalkte') hebben een onaangenaam hamerend effect. Hier is meer sprake van klinkklank dan van zin-klank. Deze woorden staan in schril contrast met het eerste gedeelte van deel 2, dat juist opvalt door zijn zachte sfeer. Pas in de laatste regel van deel 2 keert de harde k-klank weer terug: 'knersende remmen' (r.10). De bastaard is verkalkt: alles zit vast, is tot kalk geworden. Hij lijkt wel gefossiliseerd. Verkalking verwijst niet alleen naar geestelijke aftakeling (aderverkalking), maar ook naar geestelijk verstard zijn, niet meer open kunnen staan voor iets nieuws.

De gewenste en ongewenste personages voor de afdaling vormen een interessant contrast. De zwarte makker en de bes vertegenwoordigen respectievelijk de diepgang en de oppervlakkigheid. De verkalkte bastaard staat voor onzuiverheid en verstarring, terwijl de witte makker de zuivere onbevangenheid representeert. Opmerkelijk is, dat het lyrisch subject zich al tijdens de afdaling in de lift realiseert dat de onderneming op een mislukking uit zal lopen.

\section{Zodat geen wimper meer fladdert}

In 'Voor wie uit is op inkeer 2' gebruikt Warmond een ander beeld voor het verlangen naar inkeer en stilte en wel de berg. In. Oosterse levensbeschouwingen als taoïsme, boeddhisme en shintoisme wordt de berg in verband gebracht met geestelijke verlichting. Door zich op de berg te richten hoopt men een tot dan toe onbetreden gebied te betreden: een gebied waarin alle tegenstellingen wegvallen, waarin er geen onderscheid meer is tussen subject en object, kortom het gebied waarin de leegte-ervaring mogelijk is. Leegte is hier geen nihilistische term, maar duidt op de totale afwezigheid van onderscheid en tegenstelling.

Het lyrisch subject uit 'Voor wie uit is op inkeer 2' acht het 'welhaast niet haalbaar' dat gebied te betreden: de grens tussen dat gebied en de eigen werkelijkheid ('hier ter plaatse') wordt duidelijk ervaren. Deze grenservaring impliceert twee dingen. Allereerst dat het lyrisch subject zich ervan bewust is, dàt er een andere werkelijkheidsbeleving mogelijk is, waarin onderscheid en tegenstelling zijn opgeheven. Er is op zijn minst een zekere gevoeligheid voor die andere werkelijkheidsbeleving. Daar staat echter tegenover dat de grenservaring teleurstelling en machteloosheid oproept: 
mooi moet dat zijn maar hier ter plaatse

welhaast niet haalbaar

door iedere gedachte aan niets

rijdt met knersende remmen een tram.

Ook in andere gedichten verbindt Warmond de motieven berg en inkeer met elkaar, bijvoorbeeld in het begin van 'De snelkookpan van de tijd $8^{20}$;

wat wil je dan? de bergtop?

de inkeer

de zuiverheid

ik-loos?

Het is blijkbaar een thema dat haar bezighoudt. In een interview uit 1969 laat Warmond blijken dat ze 'het zelfversterven op een berg' een cultuurgebonden vorm vindt, waarbij ze in het midden laat of er voor haar eigen cultuur dan wel een geschikte vorm is:

Overigens vind ik het nadenken in zijn meest intense vorm -het zelfversterven op een berg- het summum; maar ik zie niet dat die vorm een mogelijkheid biedt voor onze cultuur. Ik geloof niet in navelstaren als maatschappijverschijnsel; toch is zelf-inkeer belangrijk $[\ldots]^{21}$

Dit interviewcitaat laat zien, dat Warmond niet de bedoelde ervaring als zodanig of het nastreven daarvan ter discussie stelt. Haar twijfels gelden alleen de vorm of de manier waarop.

In 'Voor wie uit is op inkeer 2' ziet het lyrisch subject een volledige contemplatieve rust als ideaal. Deze rust wordt gekenmerkt door de afwezigheid van beweging:

zodat geen wimper meer fladdert

en geen gedachtestolsel knapt

onder de vuile nagel der versterving

Het streven naar een rustige geest is een bekend thema in contemplatieve literatuur. Krishnamurti bijvoorbeeld stelt, dat een stille geest voorwaarde is voor het komen tot inzicht. Duidelijkheid, inzicht of begrip zijn slechts mogelijk als het denken is opgeschort, als de geest stil is. Slechts dan kun je heel zuiver zien en zeggen dat je

20 in: Implosic. Amsterdam 1976: 50

21 in: Ben Bos, 'Gesprek met Ellen Warmond. "Ik wil de mensen met mun poëzie leren dat ze hun nagels en tanden scherp moeten houden." De Nieuue Linie, 22-11-1969 
werkelijk begrepen hebt. Omdat je geest niet langer verward is, neem je rechtstreeks waar, aldus Krishnamurti. ${ }^{22}$

Het beoefenen van de stilte is niet alleen in een aantal oosterse levensbeschouwingen belangrijk, het speelde ook in vormen van het vroege christendom een rol. De kluizenaar Evagrius van Pontus (346-399) schreef eveneens over het cultiveren van de stilte. Als de mens vrij is geworden van alle passies ontstaat er een toestand van rust of hesychia. Op dat moment is het ervaren van God mogelijk. Deze monnikenmystiek is blijvend beoefend in het oosterse monnikendom, vooral op de berg Athos in Griekenland. Ze vertoont overeenkomsten met yoga: het lichaam roerloos houden, de blik naar binnen richten, de gedachten vanuit het hoofd af laten dalen in het hart, een kleine tekst als een mantra steeds herhalen op het ritme van de ademhaling. ${ }^{23}$ Het zich innerlijk leegmaken hield ook Meester Eckhart (ca. 1269-1327) bezig, waarbij hij zich onder meer beroept op bovengenoemde monnikenmystiek.

In de tweede strofe van 'Voor wie uit is op inkeer 2' nuanceert het lyrisch subject wat hij onder 'rusten' verstaat: de wimper beweegt niet meer, het oog kan de blik dus zonder verstoring op de berg gericht houden. De gedachten fladderen niet meer als vlinders van het ene onderwerp naar het andere, de ogen flitsen niet meer van het ene object naar het andere object. Er is slechts één fixatiepunt: de bergtop. Opmerkelijk is dat de dichter 'het oog' en niet 'de ogen' laat rusten op de bergtop. Met 'het oog laten rusten' wordt een vorm van meditatieve concentratie aangegeven. Deze concentratie lijkt geintensiveerd te worden door het categoriaal gebruikte lidwoord 'het'. Het gaat hier niet om een individueel oog of ogenpaar. De woordgroep 'het oog laten rusten' roept allerlei andere uitdrukkingen op waarin het oog een rol speelt: een en al oog zijn voor iets, iets voor ogen houden, in het oog houden. Allemaal uitdrukkingen waarin het element concentratie, het niet (meer) afgeleid worden centraal staat. Ook in andere gedichten thematiseert Warmond een andere manier van zien. De titel van het gedicht 'Focus' bijvoorbeeld wijst niet alleen vooruit naar de inhoud, maar makt ook, dat de aandacht van de lezer bij voorbaat al gericht wordt op elementen als 'scherpstellen' en 'concentreren'. Zo ontstaat er als het ware een dubbel gefocust zijn: van dichter én lezer:

Lucide oog

gericht op het bestaande

het raadsel van de tijd

achter de hand

22 J. Krishnamurti, You Ane the World. New York 1972

23 Bruno Borchert, Mystick. Het verschijnel, de geschiedenis, de nieuve uitdaging. Haarlem 1994:94 
5. een honderste seconde

van absolute aandacht

en zie: een messcherp beeld

van het onzienlijke. ${ }^{24}$

Het oog is onder andere symbool van het schouwen, het geestelijk zien. "Het oog laten rusten' uit 'Voor wie uit is op inkeer 2' lijkt op de hesychia, een toestand van innerlijk vrij zijn van alle passies, want 'geen gedachtestolsel knapt / onder de vuile nagel der versterving' (r. 5-6). De gedachten stromen niet meer, ze zijn gestold, tot rust gekomen. Zelfs de 'vuile nagel der versterving' kan ze op dat sublieme moment van rust niet ontstollen ofwel weer laten stromen. De tot rust gekomen geest heeft de zorgen van de alledaagse realiteit getranscendeerd.

Ook in een levensbeschouwing als het taoisme ligt het accent op het bereiken van een rustige geest. Wanneer de overspannen geest eenmaal zijn innerlijke stilte herwonnen heeft, treedt de wijsheid op natuurlijke wijze aan de oppervlakte. Confucius zegt het zo:

Het geluk is daar waar alle beweging ophoudt.

Zij die niet kunnen ophouden,

Rennen nog, zelfs wanneer ze zitten.

Als zien en horen met het innerlijke communiceren,

En de verstandelijke kennis naar buiten is verbannen,

Komen de goden in je wonen,

Zoveel meer de mensen.

Dit heet: de transformatie van de Tienduizend dingen. ${ }^{25}$

\section{De vuile nagel der versterving}

In 'Voor wie uit is op inkeer 2' gebruikt Warmond een beeld dat contrasteert met de nagestreefde geestelijke zuiverheid, namelijk 'de vuile nagel der versterving' (r.6). Deze 'vuile nagel' kan het gedachtestolsel laten knappen en aldus bewerkstelligen dat de stroom van onrustige gedachten weer op gang komt. Wat kan er met dit intrigerende beeld bedoeld zijn?

Versterving associeer ik in eerste instantie met ascese. Maar waarom wordt ascese, een streven naar zuiverheid van geest door af te zien van aardse genoegens, hier in verband gebracht met een 'vuile nagel'? Vuile nagels zijn immers het resultaat van onverzorgdheid of van een bepaald soort arbeid, bijvoorbeeld tuinieren. Het beeld van de vuile nagel roept bij mij een intertekstuele echo op, namelijk de titel van

24 in: Vuchtstroken uan de taal. Amsterdam 1988:17

25 in: Kristofer Schipper, Taa. De lavende religie van China. Amsterdam 19892:251-252 
Sartres toneelstuk Les mains sales (1947). Ik heb in eerdere hoofdstukken aangegeven, dat de uitdrukking 'vuile handen' door Warmond diverse keren gebruikt is, ook in interviews. Deze uitdrukking kon in die gevallen vanuit een existentialistische context geinterpreteerd worden. Leven impliceert vuile handen maken, al kun je bijvoorbeeld door politiek geëngageerd te zijn wel proberen zo zuiver mogelijk te blijven.

In 'Voor wie uit is op inkeer 2' geeft het beeld van de vuile nagel aan, dat je wel kunt verlangen naar geestelijke stilte en zuiverheid, maar dat de realiteit er iedere keer weer tussendoor komt. Dit idee wordt versterkt door de antithese waarop het gedicht gebaseerd is. Niet alleen het lyrisch subject, maar ook de lezer schrikt hiervan op: de serene stilte en rust die in het eerste gedeelte van het gedicht worden opgeroepen worden ineens doorbroken door irritant lawaai ('knersende remmen') en door beweging ('rijdt [...] een tram').

\section{Hier ter plaatse}

De aanduiding 'hier ter plaatse'(r.7) vormt duidelijk een oppositie met de bergtop uit de eerste strofe van het gedicht, maar waar is ze te situeren? In ieder geval beneden, in tegenstelling tot de bergtop. Maar waarom die extra precisering 'ter plaatse'? Wordt ermee bedoeld: hier waar ik aanwezig ben, waar ik woon? Verwijst het dus naar een stad in Nederland waar nog trams rijden of breder gesteld naar de westerse cultuur? Of is er ook nog iets anders aan de hand?

In 'Voor wie uit is op inkeer 2' speelt de Himalaya een rol, echter niet als specifieke geografische aanduiding, aangezien dit gebergte vervangen kan worden door 'willekeurig welke bergtop' (r. 2). Door deze laatste toevoeging wordt het specifieke -de Himalaya- verbreed tot ieis algemeners: welke bergtop dan ook. Die veralgemening geeft het berglandschap een symbolische meerwaarde. Als het berglandschap er echter een symbolische betekenis bij krijgt, kan dat ook gelden voor andere plaatsaanduidingen in dit gedicht, zoals 'hier ter plaatse' waarmee het een contrast vormt. De rust van de berg vormt een scherpe tegenstelling met de stedelijke lawaaiigheid van 'hier ter plaatse', geaccentueerd door de snerpende è-klanken in de laatste regel: 'rijdt met knersende remmen een tram'. De berg is in dit gedicht geen plaats om te beklimmen, maar een punt waar de geest zich op richt zodat er geestelijke rust kan ontstaan. Zo zoụ 'hier tẹ plaatse' ook naar de eigen geest kunnen verwijzen. Een ander argument is dat ook de ruimtelijke aanduidingen in deel 1 ('de mijnschacht van de geest' en 'de lift') een geestelijke toestand aanduiden. In beide delen belemmeren storende geluiden het bereiken van de beoogde ervaring.

In onder meer het zenboeddhisme worden de geest en afleidende gedachten vergeleken met een heldere hemel waar regelmatig wolken langs komen drijven, varierend van eenvoudige wolkjes tot enorme dreigende donderwolken. In plaats van deze klassieke natuurmetafoor (de bewolkte lucht) gebruikt Warmond een 
moderne grote-stadsmetafoor die op hetzelfde neerkomt. De verlangde 'gedachte aan niets' wordt vrijwel onmogelijk gemaakt door allerlei storende gedachten die als lawaaiige trams er dwars doorheen rijden.

Een enkele keer lijkt het wel mogelijk, zoals blijkt uit het volgende citaat:
$[\ldots]$
het verst reikt de blik
van de blinde
naarmate ik langer staar
naar niets bedaart de wereld
en hevelt zich over naar nevels
ver weg en verder en weg
denkend
niet voor of tegen
$[\ldots]^{26}$

Maar in 'Voor wie uit is op inkeer' is de verhouding tussen de werkelijkheid en de verlangde transcendentie een dissonante verhouding, geaccentueerd door de dissonante geluiden van de 'kwekkende bes' in deel 1 en de 'knersende remmen' van de tram in deel 2. Ook de dichter J.C. van Schagen schrijft met de nodige ironie in 'Narrenwijsheid II' over een ervaring waarin het beleven van het 'Al' gefrustreerd wordt door lawaai, hoewel dat in zijn geval allereerst van buiten komt:

ge breiddet de armen uit om het Al te omvatten

maar trok toen niet een trek van wrevel over uw gelaat

wijl juist uw buurmans' fonograaf te wauwelen begon? ${ }^{27}$

Dat deze frustrerende ervaringen niet tijd- of cultuurgebonden zijn wordt geillustreerd door de gedichten van Han-shan ('koude berg'), die tijdens het begin van de T'ang Dynastie (618-907) in de T'ien-t'ai-bergen in het zuidoosten van China leefde. Hij schreef ruim driehonderd gedichten over zijn kluizenaarsleven in de bergen. Veel van deze gedichten zijn vooral beschrijvend van aard en dat levert prachtige landschapsgedichten op. In andere gedichten echter symboliseert het berglandschap de spirituele zoektocht naar de verlichting en de moeilijkheden en obstakels die men daarbij onderweg tegenkomt. Han-shan verwoordt af en toe zijn frustraties, teleurstelling en wanhoop die ook deel uitmaken van het moeizaam

26 uit: 'Denken'. In: Gesloten spiggels. Amsterdam 1979:17

27 geciteend in: E Opheten, Op zock naar evenuicht. De filosofische ontwikkeling van J.C. van Schagen in de turintiger jaren. Leiden 1983: 83 
verlopende proces op, weg naar verlichting. Alleen iemand die de zorgen van de wereld transcendeert, kan de top van de berg ofwel de verlichting bereiken. In gedicht 147 uit Han-shan zijn teleurstelling en verdriet. Zijn onmacht om tot verlichting te komen wordt weerspiegeld in de wolken die hem het zicht op de top ontnemen, terwijl zijni onrustige gedachten als het ware geëchood worden door allerlei natuurgeluiden als de klagende wind, apengeluiden, ruisende bomen en kwetterende vogels:

Alone I sit, constantly disappointed and sad;

My feelings and innermost thoughts - how troubled they are and forlorn.

The clouds at the waist of the mountain spread out thick and dense;

The wind at the mouth of the valley - mournfully it sighs and moans.

5. Gibbons come - the trees shiver and shake;

Birds enter the wood - their singing echoes tweet, tweet.

Pressed now by the times, my temple hair dishevelled hangs down.

At the end of the year, I'm old, filled with pain and regret. ${ }^{28}$

\section{Conclusie}

In het tweeluik 'Voor wie uit is op inkeer' hebben zowel de mijnschacht als de berg een spirituele betekenis. Het eerste beeld symboliseert de katabasis, de tocht omlaag, terwijl het tweede beeld de anabasis, de tocht omhoog, symboliseert. Ondanks het verschil in beelden zijn de overeenkomsten opmerkelijk. Het lyrisch subject ervaart de mijnschacht, of beter de daaronder liggende mijn, en de bergtop als gebieden die door bepaalde omstandigheden buiten zijn bereik liggen. Maar tevens wordt via subtiele signalen (bijvoorbeeld 'welhaast' in deel 2) aangegeven dat deze spirituele gebieden niet per definitie onbereikbaar zijn. Onder bepaalde voorwaarden is realisering mogelijk, al zal dat niet eenvoudig zijn. In beide gevallen frustreert de lawaaiige interventie van een onrustige geest echter het bereiken van het doel. De belemmering van dit verlangen naar stilte, zowel auditief als kinetisch (stilzitten), maakt Warmond zichtbaar door allerlei termen te gebruiken uit de woordvelden 'stilte' en 'rust'. Uit onderstaand schema blijkt, dat deel 1 gedomineerd wordt door auditieve anduidingen, terwijl in deel 2 de kinetische termen overheersen:

28 in: Robert G. Henricks, The Poetry of Han-shan. A Complete, Annotated Thanslation of Cold Mountain. New York 1990: 215 


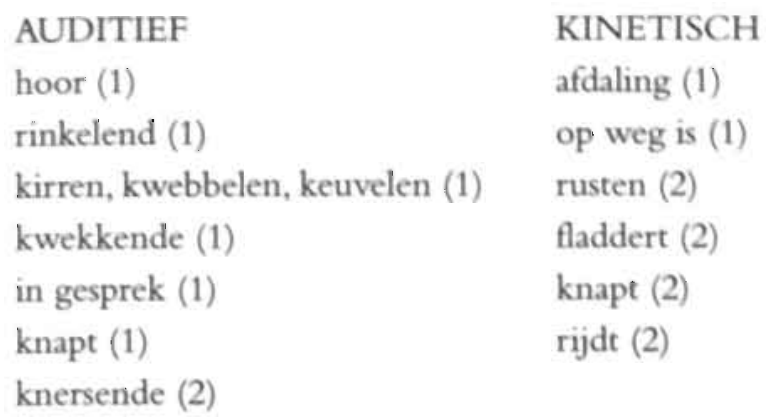

Uit de bespreking van de gedichtenreeks 'Everest/Himalaya' zal blijken dat het tegendeel, namelijk de afwezigheid van geluid en beweging, een belangrijk kenmerk is van de aldaar opgeroepen mystieke ervaring.

De titel van 'Voor wie uit is op inkeer' bevat allerlei betekenislagen die met de complexe inhoud van de beide delen verband houden. De uitdrukking 'ergens op uit zijn' betekent 'met een bepaald doel ergens heen zijn' of 'iets willen verkrijgen". Het lyrisch subject wil graag tot inkeer komen, maar daarvoor moet hij zichzelf als het ware loslaten en 'uit' zijn lawaaiige gedachten weg zien te komen. Tegelijkertijd klinkt er in de titel een andere uitdrukking door: 'ergens uit zijn' kan ook betekenen dat iemand zijn concentratie verliest, bijvoorbeeld bij het spelen van een muziekstuk. Op weg naar inkeer verliest het lyrisch subject zijn concentratie, waardoor het beoogde resultaat niet bereikt wordt. Net als in diverse andere gedichten van Warmond blokkeert het reflexieve bewustzijn zowel in deel 1 als in deel 2 van 'Voor wie uit is op inkeer' de beoogde eenheidservaring. 
[ 214] 


\section{DE BERG IN VOGELVLUCHT}

'Voor wie uit is op inkeer' is niet het enige gedicht van Warmond dat een verwijzing bevat naar de Himalaya of naar de berg in het algemeen. Het is ook niet het enige gedicht in haar oeuvre waarin de berg in cen spirituele context wordt geplaatst. Een voorbeeld daarvan is de zesdelige gedichtenreeks 'Everest/ Himalaya ${ }^{1}$, waar ik in hoofdstuk XI dieper op inga.

Het literaire bergmotief kent vele kanten. De berg vertegenwoordigt onder meer uiteenlopende zaken als de hoogmoed, de chaos, het sublieme en de ultieme uitdaging. Om te kunnen bepalen welke visie op de berg Warmond representeert, schets ik in dit intermezzo in grote lijnen de berg als cultureel-historisch motief. Daarbij staan de volgende vragen centraal: op welke manieren is er in de loop der tijden tegen de berg aangekeken? Is er verschil in de manier waarop het westen en het oosten tegen de berg aankijken? Bij welke opvatting sluit Warmonds visie aan?

\section{De berg in het westen}

Bergen behoren tot de materiële wereld, maar tegelijkertijd roepen ze door hun imposante verschijning een sacrale sfeer op. De houding ten aanzien van het berglandschap is in het westen niet altijd dezelfde geweest. Zo'n driehonderd jaar geleden zag men bergen als ontsierende wratten en puisten. Deze uitwassen van de aarde vormden een contrast met het toen heersende beeld van het ideale landschap, dat gekenmerkt wordt door symmetrie, de juiste verhoudingen, evenwicht en harmonie. In The Sacred Theory of the Earth (1726) schrijft de Engelsman Thomas Burnet:

"'Tis prodigious to see and to consider of what Extent these Heaps of Stones and Rubbish are! ... in what Confusion do they lie? They have neither Form nor Beauty, nor Shape, nor Order ... There is nothing in Nature more shapeless and ill-figured than an old Rock or a Mountain ...2

Christelijke theologen raakten geintrigeerd door het bestaan van bergen: waarom en vooral wanneer verschenen er bergen op aarde? Bestonden ze al vóór de zondvloed of zijn ze ten gevolge daaryan ontstaan? Is er een relatie tussen het ontstaan van bergen en de zonden van Adam en Eva?

Calvijn, opgegroeid in de bergen, beantwoordt de laatste vraag ontkennend. Het kwaad zit in de mens, de aarde zelf is onschuldig. De natuur was misschien niet zo mooi als in de dagen van het paradijs, aangezien de originele schoonheid verwoest is door de zondvloed, maar zij was wel dezelfde aarde als in het begin van de schepping. Bergen makkten dus deel uit van de oorspronkelijke schepping.

in: Ondening. Amstendam 1981: 11-16

2 geciteerd in: Edwin Bernbaum, Sacred Mountains of the World. San Francisco 1990: 121 
Volgens Luther, opgegroeid op het platteland, daarentegen was de oorspronkelijke aarde een model van schoonheid. Maar de toenemende zondigheid der mensheid wordt weerspiegeld in een voortschrijdende degeneratie van de natuur. De in zijn ogen lelijke en grillige bergen behoorden dus niet tot het oorspronkelijke paradijselijke landschap. ${ }^{3}$

Deze negatieve visie wordt niet ondersteund door het Oude en Nieuwe Testament. Mozes ontvangt de tien geboden op de berg Sinaï, waar God ook verschenen is in het brandende braambos. In Deuteronomium 32: 48-50 vraagt Jahwe Mozes naar de berg Nebo te gaan, alwaar hij Kanaän, het beloofde land, kan zien liggen. In de psalmen wordt de berg geassocieerd met vrede en rechtvaardigheid, terwijl in Ezechiël 28: 14 de profeet Ezechiël naar de hof van Eden verwijst als 'de heilige berg van God'. In het Nieuwe Testament zijn bergen verbonden met belangrijke gebeurtenissen in het leven van Jezus. De Bergrede, zijn belangrijkste en invloedrijkste rede spreekt hij uit op een heuveltop bij het Meer van Galilea. Zijn transfiguratie van mens in de Zoon van God vindt plaats op de berg Tabor in de buurt van Nazareth (Matth. 17: 1-3) en na zijn dood verschijnt hij aan elf van zijn leerlingen op een berg in Galilea (Matth. 28: 16-20).

In de westerse literatuur is de berg een bekend topos. Onder invloed van de klassieken hebben de 'godenberg' Olympus en de 'muzenberg' Parnassus zich een plaats verworven in de westerse literatuur, met name tijdens de renaissance. Het idee dat de dichter een goddelijke spreekbuis is, hangt met dit klassieke topos samen. Deze verheven opvatting van poëzie wordt door moderne dichters als Remco Campert bekritiseerd. In 'Geen gedicht, Hendrik de Vries' reageert hij op een uitspraak van dichter en criticus Hendrik de Vries. ${ }^{4}$ De titel is dubbelzinnig: het onderstaande vers zal door zijn aardse gerichtheid in de visie van De Vries geen echt gedicht zijn, terwijl volgens Campert de poëzieopvatting van De Vries geen interessante gedichten kan opleveren. In het gedicht speelt Campert een geestig spel met woorden die hoogte en diepte aanduiden:

\section{GEEN GEDICHT, HENDRIK DE VRIES}

"betekent "poëzie" niet, behalve dichtkunst, ook goddelijke levensgeur, onsterfelijkheidsaroma?" Hendrik de Vries in Vrij Nederland, 23 nov. '57

Ik hou niet van bergen

het beklimmen is nog tot daaraantoe

maar het op de top staan en vanaf het bereikte

bezien wat beneden ligt

3 zie: Marjorie Hope Nicholson, Mountain Gloom and Mountain Glory. The Development of the Aesthetic of the Infinite. Seattle/London 1997: 97-102 (oorspronkelijk verschenen in 1959): 96-104

4 Remco Campert, "Verspreide gedichten 1950-1994'; opgenomen in Dichter, Amsterdam 1995;623 
5. is dodelijk vervelend en ondanks de hoogte weinig verheffend.

ook de gesprekken met goden,

die je op bergen niet ontlopen kunt

ja waar het hele klimmen om begonnen is

10. zijn van een duizelingwekkende onmenselijkheid

je neemt er behalve wat stank van onsterfelijkheid.

niets van mee naar beneden

als je ooit beneden komt wat zelden gebeurt

liever loop ik

15. beganegronds rond

of sta ik

als er dan iets verticaals gebeuren moet

in een niet al te diepe kuil

dicht bij de kleine beesten

20. met mijn voeten in de warme aarde

met mijn neus in de koude wind

Het literaire landschap bevat niet alleen mythologische bergen, maar ook 'christelijke' bergen, die meestal een theologische connotatie hebben. Een bekend voorbeeld daarvan is de Purgatorio in de Divina Commedia van Dante (1265-1321). $\mathrm{Na}$ zijn afdaling in het Inferno beklimt Dante deze berg met als doel het aardse paradijs te bereiken, dat zich op de top daarvan bevindt. Op weg naar de top passeert hij zeven terrassen, waar de zielen van de doden zich proberen te reinigen van de zeven doodzonden die tussen hen en God in staan. In tegenstelling tot wat je zou verwachten, zal de beklimming steeds lichtvoetiger verlopen, aldus Vergilius, Dantes gids. De beklimming van de berg Purgatorio symboliseert de spirituele vooruitgang van de ziel:

$[\ldots]$ De berg is zo geschapen,

dat we aan zijn voet het klimmen moeilijk achten, doch minder zwaar wanneer we hoger komen.

Zohaast hij u dus lieflijker gaat schijnen

en 't klimmen voor uw voet zo licht zal wezen

als 't voor een bootje is om stroomaf te drijven,

dan zijt ge 't einde van uw weg genaderd,

waar zoete rust u wacht na 't moeizaam zwoegen. ${ }^{5}$

5 uit: 'Het Vagevuur', Viende Zang, vers 88-96. In: Dante Alighieri, De Goddelijke Komedic. Antwerpen/Amsterdam $1977^{3}: 225$ (vertaling C. Kops O.F.) 
Is de berg bij Dante alleen nog een literair topos, bij Petrarca komt de reële berg in zicht. Het verslag van zijn beklimming van de Mont Ventoux is een vroege voorloper van een veranderende houding ten aanzien van de berg. Petrarca (1304-1374) ervoer als een der eersten de verrukking van het berglandschap, maar op de top valt hij door het lezen van Augustinus terug in de oude, negatieve visie. Hij beklom in 1336 de ruim 1900 meter hoge Mont Ventoux, gelegen in de Vaucluse. Zijn verslag is geschreven in briefvorm aan de augustijner monnik. Dionigi di San Sepolcro. Omdat zo'n beklimming in zijn tijd niet gewoon was, heeft Petrarca de behoefte zich ervoor te verontschuldigen. Op de top leest hij in de willekeurig opengeslagen Belijdenissen van Augustinus de volgende passage:

En de mensen gaan om te bewonderen de hoogten van de bergen en de machtige golven van de zee en de brede stromen van de rivieren en de gang van de oceaan en de omloop van de hemellichamen, en zij verlaten zichzelf. (Conf. $\mathrm{X}, 8,15)$

Zijn brief krijgt een allegorisch karakter, als hij het beklimmen van de berg in verband brengt met menselijke hoogmoed:

Bij iedere stap speelde deze vraag mij door het hoofd: Als men zonder aarzeling zich zoveel zweetdruppels en zoveel moeite getroost om het lichaam een klein beetje dichter bij de hemel te brengen, welk kruis, welke kerker, welke pijniging zou dan de ziel kunnen afschrikken die tot God wil naderen en de opgeblazen hoogte van hoogmoed en het menselijke lot onder zijn voeten wil vertrappen? [...] Hoezeer zouden wij ons moeten inspannen, niet om hogere grond, maax om de door aardse driften opgestuwde verlangens onder de voeten te krijgen! ${ }^{6}$

In de renaissance krijgen dichters en schilders meer belangstelling voor de natuur. maar pas in de romantiek worden bergen ervaren als sublieme manifestaties van het oneindige. Romantische werken beschrijven op lyrische wijze Alpenpanorama's en idealiseren het leven van de bergboeren. John Ruskin, invloedrijk Engels criticus die de idealen van de romantische kunst verkondigde, beschreef de bergen in religieuze termen:

great cathedrals of the earth, with their gates of rock, pavements of cloud, coirs of stream and stone, altars of snow $[\ldots]^{7}$

6 zie: F Petrarca, De top un de Ventoux. Vertaald en van antekeningen voorzien door Chris Tazelaar. Baarn 1990: 16-17

7 geciteend in: E. Bernbaum 1990: 231 
In haar boek Mountain Gloom and Mountain Glory (1959/1997) signaleert Marjorie Hope Nicholson dat het klassieke ideaal van regelmatigheid, proportie, patronen en symmetrie in de achttiende eeuw vervangen wordt door idealen van diversiteit, onregelmatigheid, variëteit, oneindigheid en uitgestrektheid. ${ }^{8}$ Verklaringen voor deze omslag, zoals de pionierstheorie en de navolgingstheorie, zijn echter niet overtuigend. De pionierstheorie stelt dat er eind achttiende eeuw meer mensen dan daarvoor de Alpen overtrokken, maar deze theorie verklaart niet waarom men ineens geimponeerd werd door het berglandschap, terwijl dat daarvoor niet zo het geval was. De navolgingstheorie wijst op de relatie met de andere kunsten. Verandering in de literaire smaak zou voortkomen uit veranderingen in andere kunsten als tuinkunst, schilderkunst en architectuur. Dit is echter een verschuiving van het probleem, aangezien niet verklaard wordt waaróm die andere kunsten veranderen. Nicholson zoekt de verklaring in een door wetenschappelijke ontdekkingen veranderd wereldbeeld. Tot in de zeventiende eeuw worden bergen beschreven in algemene of allegorische termen, ontleend aan de klassieken en aan de bijbel. Het grillige berglandschap ontmoet weinig sympathie in een visie waarin men God ziet als een klassiek estheticus die uitgaat van symmetrie en proportie. Op een gegeven moment, ongeveer halverwege de zeventiende eeuw, komt de theologie tegenover de nieuwe wetenschap te staan. Oude ideeèn van orde en proportie moeten worden herzien door revolutionaire ontdekkingen op het gebied van astronomie, geologie en microbiologie. Emoties die eens gereserveerd waren voor God worden getransponeerd naar de interstellaire ruimte en naar de bergen. Men vindt bergen niet zozeer mooi, als wel subliem. Ze zijn manifestaties van de goddelijke macht. De wetenschap liet mensen exacter zien en dat had ook effect op de achttiende-ecuwse Engelse dichtkunst. Bergen, grotten, exotische landschappen, oceanen en grote rivieren zijn de uitingen van variëteit en diversiteit, uitgestrekt en majestueus. Omdat de oude begrenzingen vạn tijd en ruimte zijn verdwenen, gaat men met andere ogen naar de aarde kijken. In de achttiende eeuw baseren dichters zich niet meer zozeer op literaire bronnen, maar op actuele observatie. Zien wordt belangrijker dan ooit daarvoor, aldus Nicholson.

Bernbaum 1990 betwijfelt of er een totaal nieuwe houding ten aanzien van de bergen is ontstaan. Het ontzagwekkende, het heilige wordt vanouds op twee manieren ervaren: als iets demonisch of als iets goddelijks. Beide aspecten zijn vaak tegelijkertijd aanwezig, alleen niet altijd in een evenwichtige verhouding. Afhankelijk van tijd en cultuur heeft dan weer eens het ene, dan weer het andere aspect de overhand. Volgens Bernbaum zijn deze twee houdingen ook tijdens de romantiek met elkaar verweven, alleen is de ene houding wat meer naar de achtergrond verdwenen, terwijl de andere visie wat meer naar voren is gekomen.

8 zie: Nicholson 1997, met name de 'Introduction' p. 17-33 
Deze visie wordt gedeeld door Von der Thüsen $1991^{9}$. Hoewel Von der Thüsen over de vulkaan als symbool van de achttiende eeuw schrijft, gelden zijn opmerkingen ook voor de beleving van de berg. Hij noemt drie factoren die een centrale rol spelen in de ervaring van het sublieme. Allereerst de fascinatie voor het onbetredene: naarmate men meer macht over de natuur krijgt, wordt de aantrekkingskracht van het ongetemde of ontembare in de natuur sterker dan ooit. Dat is met name het geval in Engeland, waar de industrialisatie het eerst op gang komt. De tweede factor is de eis dat men zelf in veiligheid moet zijn, want ondanks een zekere beheersbarheid is de natuur niet volledig veilig. De natuur kan alleen tot schouwspel worden, als men zich op een veilige plaats bevindt. Von der Thüsen vergelijkt de ervaring van het sublieme met de beleving van iemand die voor een raam staat te genieten van bliksem en storm. De derde factor is, dat de toeschouwer vanwege zijn veilige plek weliswaar nauwelijks bedreigd wordt door deze natuurverschijnselen, maar dat hij toch tegelijkertijd een residu van angst ervaart. Deze angst is atavistisch, dat wil zeggen van generatie op generatie overgeleverd, ook in tijden waarin die angst niet meer of minder reëel werd. Volgens Von der Thüsen is deze restangst gebleven, omdat de psychologische evolutie van de mens nu eenmaal langzamer verloopt dan de technische ontwikkelingen. Toch heeft deze angst ook een reële basis, aangezien in de beleving van het sublieme bewust de grens tussen het veilige en het onveilige wordt opgezocht. Het wordt steeds gewoner om te genieten van de natuur vanaf een bergtop die men met gevaar voor eigen leven heeft beklommen. Ook de ballonvaarten rond 1800 passen in dit beeld, aldus Von der Thüsen.

Het begrip 'subliem' heeft in de loop der tijd een betekenisverandering ondergaan. In onze tijd geldt het sublieme als de hoogste vorm van het schone, maar in de achttiende eeuw vormde het een oppositie met 'de begrippen 'schoon' en 'mooi'. Het sublieme wordt ervaren in datgene wat groot van afmeting, massief en solide is, terwijl het schone/mooie te vinden is in het delicate en kleine. Bovendien zijn in de ervaring van het sublieme zowel fascinatie als angst aanwezig, mits degene die dit alles ervaart zich tegelijkertijd veilig weet. Geleidelijk aan verdwijnt de oppositie tussen 'subliem' en 'schoon' en worden ze alleen nog als kwantitatieve verschillen ervaren. Er blijken overigens frappante overeenkomsten te bestaan tussen het sublieme en het heilige. De ervaring van het heilige kent een soortgelijke ambivalentie: ook zij is zowel fascinerend als angstwekkend. ${ }^{10}$

De opkomst van het woord 'subliem' weerspiegelt een herwaardering van de ruwe natuur, die nog niet door de mens getemd is. Omdat in Europa bergen tot de laatste gebieden behoorden waar nog wilde natuur voorkwam, gingen ze een sleutelrol spelen in de nieuwe sensibiliteit, aldus de filosoof Ton Lemaire in zijn studie Met open zinnen (2002). Zowel Verlichting als romantiek hebben daaraan bijgedragen. Het vroege alpinisme is niet alleen mogelijk door nieuwe natuurwetenschappelijke

9 J. von der Thüsen, 'De vulkaan. Collectieve wasneming en symbolisering in de achttiende ecuw' In: R. Engbersen, Th. Jansen, W. Witteveen (red.), Het retorische antwoond. Utrecht 1991: 127-144 10 ontleend aan: Ton Lemaire, Met open zinnen. Natuar, landschap, aarde. Amsterdam 2002: 77-103 
kennis en technische vindingen, maar ook door een veranderd gevoel voor natuur, waardoor de berg als het ware gerehabiliteerd wordt. Deze twee invloeden blijken ook uit de manieren waarop het beklimmen van bergen wordt beschreven: enerzijds in termen van bedwingen en veroveren, anderzijds in termen van participatic en verbondenheid. ${ }^{\text {II }}$

Het is enigszins ironisch dat de herwaardering van de natuur vanuit de steden begonnen is. Lemaire wijst op het verband tussen enerzijds een breuk met het land en anderzijds de idyllische en arcadische verbeeldingen daarvan. Door de toenemende verstedelijking en industrialisering raakt de mens steeds meer verwijderd en vervreemd van de natuur en de daarbij behorende zintuglijke ervaringen. De vele landschappen uit de negentiende eeuw bijvoorbeeld komen voort uit een stedelijk verlangen naar een authentieker leven op het land. Een land dat overigens ook in die tijd al bedreigd werd door de moderne tijd.

Een soortgelijke tendens is terug te vinden in de romantische natuurlyriek, die eveneens een poging is om de ongebroken verhouding tussen mens en natuur te hervinden. Tegelijkertijd is dit een tragische zoektocht, aldus Lemaire. Juist omdat het westen een dualistische houding innam, waardoor het milieu als fysische natuur werd opgevat, kreeg het macht over zijn milieu. Het is de vraag of de mens in het westen weer aan kan knopen bij een oorspronkelijke, nog ongescheiden natuur. Hoewel de berg in de moderne Nederlandse poëzie (uiteraard) een marginale positie inneemt, zou er toch een aardige bundel samen te stellen zijn van Nederlandse berggedichten. De thematiek varieert van de heroïek van het klimmen zoals in 'Mount Everest' van A. den Doolaard tot de berg als innerlijk landschap in het werk van H.C. ten Berge. 'Mount Everest' 12 van Den Doolaard is opgedragen aan de Engelse bergbeklimmers George Leigh Mallory en Andrew Irvine, die op 8 juni 1924 voor het laatst gesignaleerd werden op weg naar de top. Hun verdwijning levert nog steeds stof voor discussie over de vraag of ze de top hebben bereikt of niet. Pas in 1999 werd het lichaam van Mallory teruggevonden, maar deze vondst kon het raadsel niet oplossen. Den Doolaard roemt in ronkende verzen vooral de tragiek en de bijna mythische heldhaftigheid van beide bergbeklimmers:

En, toen zij wagglend stegen tot den top,

Brekend onder den druk van 't zuurstofapparaat

De knieën niet meer kruipen konden, hun lijven

Saamtuimelend in een woordeloos varwel

Neersloegen in sneeuwval, warrelend op den wind,

En binnen der armen boog lag ' $t$ bonzend hoofd,

Waar met den tragen teruggang van het bloed

De laatste droom uit wegdreef ...

11 zie Lemaire 2002: 98

12 in: A. den Doolaand, De verliefde betomuerker (1926). Met dank aan Wiel Kusters, die zo vriendelijk was mij zijn verzameling berggedichten ter beschikking te stellen. Zie ook: Wiel Kusters, 'Over het beklimmen van de Parnassus.' In: Litenatuur 1996, afl. 2: 86-91 
Klaroenden de winden toen, dreunde de aarde,

Talmden de sterren in hun strakke vaart,

Drongen wolken driftig aaneen, hen omlaag te dragen?

... Of namen wind en sneeuw en sterren hen?

Opmerkelijk is het in 1946 gepubliceerde Mnemosyne in de bergen, een episch gedicht in negen zangen van Simon Vestdijk. Opmerkelijk, omdat het gedicht in bepaalde passages een visie bevat die kenmerkend is voor de periode die aan de rehabilitering van het berglandschap voorafging. Een voorbeeld daarvan uit de zevende zang:

Wat al kegels, horens, tanden, wallen,

Diep verbrokkeld en uiteengevallen,

Wat al overdaad van smalle schachten:

Chaos, zonder wijze tegenkrachten

Die de harmonie in het te veel

Waarborgen ... Uit hun verweerde keel

Spuwen kloof aan kloof het ramm'lend braaksel

Van hun gruis tot waaiers van lomp maaksel:

Uitgestorte wansmaak $[\ldots]^{13}$

Uiteenlopende dichters als Verwey, Gorter, Kouwenaar, Andreus, H.C. ten Berge, Van Daalen, Nooteboom, Warmond en de al genoemde Vestdijk en Den Doolaard thematiseerden de berg in hun werk. In het kader van dit boek ontbreken mij helaas de tijd en de ruimte om dieper op dit alles in te gaan. Dit onderwerp vereist een aparte studie, die veel interessant materiaal zou kunnen opleveren over de berg als literair motief in de Nederlandse literatuur. ${ }^{14}$ In hoofdstuk XI lever ik hieraan een bijdrage door uitgebreider in te gaan op de gedichtenreeks 'Everest/Himalaya' van Ellen Warmond.

\section{De berg in het oosten}

De spirituele wereldbeschouwing van een bepaalde cultuur weerspiegelt zich in de manier waarop men het landschap ervaart en in de manier waarop men met het landschap omgaat. ${ }^{15}$ Zo zijn er duidelijke verschillen tussen de joods-christelijke traditie aan de ene kant en de oosterse traditie aan de andere kant.

In de dominante joods-christelijke traditie is het goddelijke of absolute niet immanent maar oneindig boven alles verheven. Tegenover en boven de zintuiglijk waarneembare wereld bevindt zich een hogere, ideale en spirituele wereld. Volgens

13 in:Simon Vestdijk, Mnemosyne in de bengen. Een episch gedicht in negen zangen. Den Haag $1960^{2}: 103$

14 Pooltochten, bergbeklimmingen, afdalingen in de arde of de diepzee en het verlangen te kunnen vliegen hangen met elkaar samen. Zie Wiel Kusters, Pooltodhten. Amsterdam 1989: 28

15 zie: Ton Lemaire, Filosofie nun het landschap Baarn $1970^{5}$ 
Lemaire heeft dit niet alleen tot gevolg dat de aardse werkelijkheid gerelativeerd en soms zelfs geminacht wordt, maar ook dat zintuiglijkheid en lijflijkheid ervaren worden als facetten die het contact met het goddelijke hinderen of zelfs geheel onmogelijk maken. ${ }^{16}$

Lemaire vermeldt niet, dat er ook binnen de christelijke traditie een tegenstroom was. Het bekendste voorbeeld is de middeleeuwse mysticus Franciscus van Assisi (1182-1226), die in eenheid wilde leven met de gehele schepping: niet alleen met mensen, maar ook met dieren, planten, zon en maan. Deze verbondenheid komt ook tot uiting in zijn beroemde 'Zonnelied', warin hij alle schepsels zijn broer of zuster noemt: alles en iedereen vormt één grote familie van de éne Vader. In dit lied looft hij ook de negatieve krachten van de natuur. Antropocentrisme speelt in de visie van Franciscus geen rol: er is geen hiërarchie tussen de schepsels, wat impliceert dat de mens zich geen bezitter of heerser mag wanen. ${ }^{17}$ Franciscus' visie heeft wat de omgang met de natuur betreft de dominante christelijke traditie echter niet kunnen veranderen.

De verhouding van de Chinees tot de natuur wordt gekenmerkt door een diepgaande verbondenheid. Door zijn nadruk op onderlinge afhankelijkheid en complementariteit (yin en yang) is het oude Chinese denken aardser en immanenter dan het westerse dualisme. In tegenstelling tot het westen was in China de waarneembare werkelijkheid nooit verdeeld in een Schepper en het geschapene. Bepaalde landschappen riepen wel iets extra's op, maar dat was geen reden om de zin daarvan buiten zichzelf te zoeken, maar juist in zichzelf als een beginsel van 'kracht' en 'kosmische binding':

de zintuiglijk ervaarbare natuur bezat in zichzelf religieuze betekenis, zonder dat de beschouwer om haar wezen te vatten verwezen moest worden naar een verre Godheid die dit alles had geschapen als teken van zijn aanwezigheid. ${ }^{18}$

Vooral boeddhistische monniken legden zich toe op het schilderen van landschappen, als een bevestiging van hun wezenlijke eenheid. Het landschap was een religieuze categorie, terwijl het in het westen steeds meer een te manipuleren, profane categorie werd.

In de Chinese poëzie spelen de berg en de ervaring van het sacrale een belangrijke rol, zoals al bleek uit: mijn bespreking van de dichter-kluizenaar Han-shan. De dichter Li Bai (701-762), ook bekend onder de transcriptie Li Po, zocht graag het gezelschap van taoistische kluizenaars die zich in de bergen hadden teruggetrokken. In veel van zijn gedichten verschijnt de berg als de andere wereld, een wereld van spirituele perfectie:

16 zie: Ton Lemaire, Met open zinnen. Natuur, landschap, aarde. Amsterdam 2002: 255-256

17 ze Bruno Borchert, Mystick. Het verschijusel, de geschiedenis, de nieuwe uitdaging Haarlem 1994 (tweede, bijgewerkte druk): 107-109

18 Lemaire 1970: 78-79 
Vraagt men aan mij waarom ik neerstreek in de groene bergen, Dan glimlach ik en antwoord niet - het hart vindt er zijn vrede:

De perzikbloesems drijven op het stromend water heen,

Dit is een kosmos op zichzelf en niet de mensenwereld. ${ }^{19}$

De perzikbloesems verwijzen naar een verhaal uit de Chinese literaire traditie waarin een visser een vallei ontdekt die achter mistige bergtoppen verborgen blijkt te liggen en waar de mensen eenvoudig en in harmonie met de Tao (de Weg) leven. In China ontwikkelde de verering van bergen zich vanuit een naïeve angst voor de krachten der natuur tot een meerlagige kosmologie. Men zag bergen onder andere als kosmische zuilen die bemiddelden tussen mensen en goden. Die heilige bergen functioneerden met name in de Han-dynastie (206 voor Chr. - 220 na Chr.) als doorgangen voor de zielen van overledenen. De grote bergen werden vervolgens plaatsen waar mensen hun verborgen krachten direct konden ervaren. Bergen waren niet meer alleen objecten van verering. Individuele zoekers trokken de bergen in om zichzelf te trainen, om goddelijke openbaringen te ontvangen en onsterfelijkheid te verwerven. ${ }^{20}$

In de Japanse kunst spelen bergen eveneens een belangrijke rol. De berg Fuji is een geliefd onderwerp. De kunstenaars van de Ukiyo-e-school schilderden deze berg temidden van scènes uit het dagelijks leven. Bekend is de serie schilderijen en tekeningen van de negentiende eeuwse Katsushika Hokusai: 100 gezichten op de Fuji. In zijn schildering 'Great Wave off Kanagawa' komt een enorme golf aanrollen naar drie boten met angstige mensen. Op de achtergrond staat de Fuji, kalm en sereen. De berg trekt de aandacht naar zich toe: het wilde water accentueert de rust van de berg. Beide elementen zijn met elkaar verbonden door de kleur wit: wit schuim op de kop van de roller, sneeuw op de top van de berg. Deze dramatische scène kan vanuit boeddhistische ideeën geinterpreteerd worden. De golf verwijst naar het begrip 'samsara', de turbulente cirkel van leven en dood, terwijl de Fuji naar 'nirvana' verwijst ofivel het bevrijd zijn van angst en lijden. De onderlinge gelijkenis van berg en golf wijst erop dat ondanks alle verschillen samsara en nirvana ook overeenkomsten hebben. Het zijn twee manieren om de werkelijkheid te ervaren: de ene bindend, de andere bevrijdend. Hokusais tekeningen van de Fuji behoorden tot de eerste werken van oosterse kunst die westerse kunstenaars beïnvloeden. Impressionisten en post-impressionisten als Manet, Degas, Gauguin en Van Gogh werden mede door hem beïnvloed. ${ }^{21}$

19 uit: Li Ba, 'Dialoog in de bergen.' In: W.L. Idema, Spiegel num de klassieke Chinese poezie num het Book der Oden tot de Qing-dynastic. Amsterdam 1991: 305

20 zie: Kiyohiko Munakata, Sacred Mountains in Chinese Ant. Urbana/Chicago 1991. An exhibition organized by Krannert Art Museum at the University of Illinors (1990) and. The Metropolitan Museum of Art, New York (1991).

21 zie Edwin Bernbaum, Sacred Mountains of the World. San Francisco 1990 


\section{Conclusie}

Nu de verschillen en overeenkomsten in de waarderingsgeschiedenis van de berg in oost en west in grote lijnen besproken zijn, rest de vraag: bij welke opvatting sluit Warmonds visie aan?

In het gedicht 'Voor wie uit is op inkeer 2', dat in het vorige hoofdstuk centraal stond, is er geen sprake van het westerse verlangen de berg te beklimmen en aldus te veroveren en te beheersen. Wel wordt het lyrisch subject gefascineerd door het sacrale karakter van de berg, een fascinatie die zowel in het oosten als in het westen voorkomt. De methode doet echter weer oosters aan: door zich op de berg te richten hoopt men een tot dan toe onbetreden gebied te betreden: een gebied waarin alle tegenstellingen wegvallen, waarin er geen onderscheid meer is tussen subject (kijker) en object (het waargenomene). De afwerigheid of beter gezegd het opheffen van onderscheid en tegenstelling wordt in het boeddhisme het ervaren van de leegte genoemd. Deze ervaring is echter niet cultuurgebonden, aangezien veel mystici uit allerlei culturen en perioden melding maken van soortgelijke belevingen. Bovendien lijkt deze ervaring ook op de pre-reflexieve ervaring, zoals die in de fenomenologie van Merleau-Ponty beschreven wordt. Kortom, Warmonds visie op de berg bevat elementen, die zowel in het oosten als in het westen voorkomen. In hoeverre deze combinatie toevallig of kenmerkend is voor haar werk, zal een nadere bestudering van de gedichtenreeks 'Everest/Himalaya' duidelijk moeten maken. 
[ 226] 


\section{EVEREST/HIMALAYA}

Als een Sherpa hem de Mount Everest aanwijst, staart de Nieuw-Zeelandse bergbeklimmer Edmund Hillary ongelovig in de aangegeven richting:

Tot mijn verwondering ontwaarde ik in de verte boven de heuvels een witte slagtand, die diep in de heldere hemel prikte. Het leek meer op een droombeeld dan op werkelijkheid. En plotseling voelde ik mij ongeduldig worden. ${ }^{1}$

Al vanaf 1921 probeerde men de Mount Everest, een hoge en onbereikbaar geachte wereld, te bedwingen. Op 29 mei 1953 bereikten Edmund Hillary en de Sherpa Tenzing Norgay uiteindelijk de top.

Bergbeklimmers worden gedreven door allerlei motieven: spanning en avontuur, nieuwsgierigheid, ontdekkingsijver, maar ook door het verlangen naar vrijheid en geluk. Als het lukt, doorstroomt hen een overwinnaarsgevoel of ondergaan ze wat ik maar de Adamservaring noem: de sensatie om als eerste een bepaald gebied te betreden. Overal in de wereld ondervinden deze beklimmers bewondering en respect.

'Everest/Himalaya' (1981) van Ellen Warmond bevat echter een andere visie. ${ }^{2}$ In het eerste gedicht van deze zesdelige gedichtenreeks is de dichter sceptisch over de pogingen van bergbeklimmers om de hoogste berg op aarde te veroveren. ${ }^{3} \mathrm{Zij}$ kiest ervoor beneden te blijven:

\section{Hoger}

kan niemand komen

dus blijf ik beneden

blinden gaan kijken

5. of het wel waar is

wit in de sneeuw

lossen zij op

tegen mijn netvlies

achter hun ongeloof.

I Ed. Hillary, Ik stond op de Everest. Amstendam 1957:19 (vertaling Gerrit Kouwenaar)

2 in: Ondening, Amstendam 1981:11-16

3 in 1978 en 1980 was Ellen Warmond in Nepal, Sikkim en andere delen van het Himalayagebied (zie Jan van der Vegt, 'Ellen Warmond.' in: Kritisch Literatuur Lexicon. Groningen 1984). Op basis van deze gegevens heb ik sterk het vermoeden dat het hier een autobiografisch gedicht betreft. Daarom kies ik er in dit geval voor om niet met de anduiding 'lyrisch subject' naar de 'ik' uit het gedicht te verwijzen, mar met 'de dichter' of met 'Warmond'. 
Deze tegendraadse visie roept een aantal vragen op: waarom wijst Warmond hit bergbeklimmen af en vanwaar de keuze om beneden te blijven?

Deze cyclus roept echter ook nog andere vragen op. Het derde, vierde en vijfe gedicht bevatten elementen die doen denken aan een mystiek idioom. Is hier indedaad sprake van een mystieke ervaring en zo ja, met welke vorm van mystick hebben we dan te maken? In het laatste gedicht doet zich de vraag voor of zon ervaring ook mogelijk is in een andere context dan de Himalaya. 'Oh, East is Eat, and West is West, And never the twain shall meet,' verzuchtte Rudyard Kipling (1865-1937) reeds in 'The Ballad of East and West'. Gaat dat ook op vorr Warmond?

Alvorens op zoek te gaan naar antwoorden op deze vragen citeer ik eerst de gehee cyclus:

\section{EVEREST/HIMALAYA}

I

Hoger

kan niemand komen

dus blijf ik beneden

blinden gaan kijken

of het wel waar is

wit in de sneeuw

lossen zij op

tegen mijn netvlies

achter hun ongeloof.

\section{3}

Ziehier het nu terug als gister

licht werpt zijn schaduw omhoog

daaronder gehurkt

bladstil

de leegte meten

als vleselijk.

\section{2}

Hier ligt de steen der wijzen vootgoed verankerd in de grond

voor iedereen toegankelijk onberoerd te vergaan.
4

In een land waar niemand mij en ik niemand verstaan kan moet ik alle taalresten kwijt (zoals: niemand kan dan toch spreken met die andere niemand?)

ik gorgel met poëzie spuw het uit en vul mijn oren met stilte mijn ogen met leegte en adem achterstevoren. 


\section{5}

De grote klokslag

valt hier eeuwig

onhoorbaar

oorverdovend

voor wie hier geboren is zijn

dit de verstaanbare tekens:

wit blanco niets

ik lees hardop

wat ik niet uit kan spreken.
6

De horizon

bijna aanraakbaar

ten minste met de blik

maar kan ik dat als ik wil?

gehinderd door mijn bagage

waar de dragers geen weet van hebben:

de grijns van de Mona Lisa

Cleopatra's diademen

de luidsprekers van Hitler

en het slijk van Hollandse polders

Calvijn in het grondwater roeiend

hier kun je voornamelijk denken:

ik hoor hier niet.

\section{Hoger kan niemand komen}

In het eerste gedicht neemt Warmond een standpunt in ten aanzien van het bergbeklimmen en het doel daarvan. Misschien was er in eerste instantie ook een verlangen om naar boven te gaan, maar ze komt daarvan terug. Het voegwoord 'dus' in r. 3 werkt verrassend: de dichter komt tot een andere conclusie dan de bergbeklimmers die voortdurend op zoek zijn naar toppunten. Ze noemt hen zelfs 'blinden'. Deze term roept een aantal așsociaties op: de klimmers zijn ziende blind, dat wil zeggen ze zijn zo bevooroordeeld dat ze niet zien wat voor de hand ligt én ze staren zich blind op deze ene mogelijkheid. Hun houding wordt toegeschreven aan ongeloof, voortkomend uit onbekendheid met andere, eenvoudiger te bereiken vindplaatsen van de wijsheid of het hogere. In het tweede gedicht zal Warmond zo'n alternatieve vindplaats aangeven.

Bevat deze cyclus in tegenstelling tot 'Voor wie uit is op inkeer 2' een negatieve visie op de berg? Dat lijkt me niet het geval te zijn, aangezien in het eerste gedicht van de cyclus niet de berg maar het beklimmen daarvan wordt afgewezen. In de derde strofe wordt een interessant spel gespeeld met het begrip 'oplossen', dat zowel 'verdwijnen' als 'opgaan in' of 'één worden met' kan betekenen:

wit in de sneeuw

lossen zij op

tegen mijn netvlies

achter hun ongeloof.

De klimmers zijn als het ware de personificaties van hun ongeloof, waar ze geheel in opgaan. Hoe hoger ze komen, hoe onzichtbaarder ze worden in de sneeuwmassa's 
van de berg. Een gebeurtenis die indruk maakt, kan nog lang op je netvlies blijven staan. Warmond is echter duidelijk niet geimponeerd door de actie van de klimmers, aangezien hun beeld oplost 'tegen' haar netvlies, alsof het beeld afgekett wordt. Het beeld raakt haar niet, ze kan zich er niet mee vereenzelvigen.

Tegenover Goethes serene 'Über allen Gipfeln ist. Ruh'4 staat Warmonds nuchtese constatering 'Über allen Gipfeln sind Gipfeln'. ${ }^{5}$ Het bestijgen van bergtoppen, al dan niet in metaforische zin, kent namelijk geen einde. Er kan hooguit sprake zin van een tijdelijke bevrediging, een bevrediging echter die vervolgens weer oplost in de volgende uitdaging: verder, hoger, meer, anders enz. Naast deze op prestate gerichte visie staat die van Lao Tze:

Zonder de deur uit te gaan

kun je de gehele wereld kennen:

zonder uit het raam te kijken,

kun je het Tau van de hemel zien.

Hoe verder je reist,

des te minder zul je kennen. ${ }^{6}$

Het lijkt me dat het eerste gedicht van de Everest/Himalaya-cyclus zich wel thuis voelt in deze oosterse context. Het werk van Warmond bevat diverse verwijzingen naar oosterse filosofie, zoals 'Lao Tse in zakformat' ${ }^{7}$ en 'Long gom. pa', dat in de bundel Ordening direct na 'Everest-Himalaya' komt. De titel van 'Long gom pa' verwijst naar de long-gom-pa renners uit het oude Tibet: renners die in meditatieve trance in korte tijd enorme afstanden af konden leggen.

\section{De steen der wijzen}

Het eerste en tweede gedicht van 'Everest/Himalaya' bevatten met elkaar contrasterende elementen:

1 yoor weinigen toegankelijk moeizaam te bereiken

betreden gebied berg voor blinden boven
2

voor iedereen toegankelijk eenvoudig te bereiken de steen blijft 'onberoerd' de steen der wijzen. beneden (in de grond)

4 in: 'Ein Gleiches'. In: Gedichte Poetische Werke I. Berlin 1976:68

5 in: Implosie. Amsterdam 1976: 21 (de titel bevat een drukfout of een grammaticale fout: het moet zijn 'Uber allen Gipfeln sind Gipfel')

6 Lao Tze, Tau Te Tsjing. Den Hag z.j.: 57

7 in: Het stniiswogelresenuat. Amsterdam 1963:21

8 in: Ondening. Amsterdam 1981:17 
De steen der wijzen is een stof waarmee alchemisten goud meenden te kunnen maken of een levenselixer waarmee de onsterfelijkheid te bereiken was. De term slaat -ook bij de oude alchemisten- niet alleen op een chemisch proces, maar tevens op een transformatie- of bewustwordingsproces in de mens:

Die Alchimie ist [...] ein magischer Vorgang, bei der sich der Wahrheitssucher in die innere Märchenwelt versetzt und die Kräfte seines Wesens erforscht. ${ }^{9}$

Deze zienswijze komt niet alleen bij alchemisten voor, maar bijvoorbeeld ook in het werk van de grondlegger van de dieptepsychologie, de Zwitserse psychiater Carl Gustav Jung (1875-1961), die overigens alchemistische beelden in zijn theorie heeft verwerkt.

De wijsheid, de kwintessens is in het hier en nu te vinden, niet zo zeer in het ginds en verder, zo leert ons het tweede gedicht. De steen der wijzen ligt echter 'onberoerd' te vergaan, ondanks zijn bereikbaarheid. Het begrip 'onberoerd' krijgt in deze context een meervoudige inhoud. Aan de ene kant geeft het aan dat de steen der wijzen niet aangeraakt wordt, terwijl dat wel zou kunnen; aan de andere kant duidt het erop dat de steen der wijzen de mensen 'onberoerd' laat, ze worden er niet door geraakt.

In eerste instantie lijkt er sprake te zijn van een contradictie: hoe kan de steen der wijzen, die immers in verband gebracht kan worden met onsterfelijkheid, liggen te vergaan? Is er een verband tussen het 'onberoerd' zijn van de steen en het 'vergaan' (r. 4) daarvan? Is het zo dat de steen langzaam verdwijnt of oplost, juist omdat hij niet aangeraakt wordt? Blijkbaar is de wijsheid waar Warmond op doelt niet iets wat je toevalt of overkomt, maar iets waar een zekere activiteit voor nodig is. Bergbeklimmen is uiteraard ook een activiteit die een zoektocht naar het Hogere kan zijn, maar in tegenstelling tot de berg is de steen der wijzen niet moeilijk te bereiken, je kunt hem zelfs aanraken. Maar de wijsheid kan niet zonder de actieve inzet van de mens, ze moet 'beroerd' worden. Dit idee van wederkerigheid is terug te vinden in diverse religieuze en levensbeschouwelijke tradities. In haar derde Albert Verwey-lezing (1988) verwijst de auteur Andreas Burnier bijvoorbeeld naar Etty Hillesum, die tegen het eind van haar Nagelaten geschriften ${ }^{10}$ het gevoel uitdrukt, dat niet wij het goddelijke om hulp moeten smeken, maar dat God onze hulp nodig heeft. Burnier zegt hierover:

Tot het kosmisch-goddelijke hebben wij met ons menselijk bewustzijn waarschijnlijk geen toegang, maar het druppeltje goddelijke geest dat wij diep

9 In: W. Bauer, J. Dümotz, S. Golowin, Lexikon der Symbole. Wiesbaden 1980: 323

10 K.A.D. Smelik, G. Lodders, R. Tempelars, Erty: de nagelaten geschriften nan Enty Hillesum, 1941-1943.

Amstendam 1986 
verborgen in onszelf kunnen aantreffen, dat heeft 'onze' hulp nodig, de hulp van onze alledaagse persoonlijkheid, om zich te kunnen manifesteren. ${ }^{11}$

Warmond plaatst dit wederkerigheidsidee niet in een goddelijke of theologische context, bij haar is dit idee juist zeer aards gericht: de steen der wijzen is 'voorgoed verankerd in de grond // voor iedereen toegankelijk' (r. 2-3).

Hoe moeten we 'hier' uit r. 1 geografisch situeren? Het verwijst in ieder geval nax een plek die in oppositie staat met de top van de berg: de voet van de Everest of het dal. Het idee dat de berg verder verwijderd is van de essentie dan het dal articuleert Warmond ook in het gedicht 'Dunner $3^{\text {' }}$ '

regen op een berg

treuriger dan in het dal

want verder

van oorsprong en einddoel

Het dal is hier niet alleen een geografische aanduiding. Door de vermelding dat he dichter bij 'oorsprong en einddoel' ligt, krijgt het dal een symbolische dimensic. Het bovenstaande korte gedichr roept bji mij een taoïstische tekst van Lao Tze op, die verduidelijkend kan werken:

De vallei en de geest sterven nimmer

ze vormen de mystieke moeder

haar poort is de oorsprong van hemel en aarde.

Deze [oorsprong] schijnt eeuwig te blijven,

en kan door gebruik nooit worden uitgeput. ${ }^{13}$

Ik volg het commentaar van de sinoloog Kristofer Schipper bij deze passage van Lao Tze. Het dal opent zich: al het water van de omringende bergen stroomt naar het dal en verzamelt zich daar. Zo opent ook de geest zich voor allerlei van buitenaf komende invloeden. De vallei is, omdat ze het water in zich verzamelt, een symbool van concentratie en, omdat het water in haar afdaalt, een symbool van verdieping. Deze twee geestelijke aspecten -concentratie en verdieping- zijn nodig om de Oorsprong te doorgronden, om tot de essentie van het leven door te dringen.

Kent de berg een sober leefklimaat, het dal daarentegen is vruchtbaar. Warmond. wijst een welhaast materialistisch te noemen spiritualiteit af die -vanuit haar visievooral gericht lijkt te zijn op verder, hoger, meer. Haar voorkeur gaat niet uit naar de zich mannelijk verheffende berg, maar naar het moederlijke dal. Daarmee kiest: ze misschien ook voor wat traditioneel het 'vrouwelijke' genoemd wordt. In

11 Andreas Burnier, Mystiek en magie in de littentuur Leiden. 1988: 84

12 in: Gesloten spicgels. Amsterdam 1979: 34

13 in: Lao Tre, Tău Te Tsjïne Den Haag z.j.: 14 
taoistische teksten wordt de vallei aangeduid al's 'de mystieke moeder' of 'de Duistere Vrouw'. Volgens Schipper verwijzen deze termen naar de aarde, een vruchtbaar lichaam met een vredige natuur. ${ }^{14}$ Hoewel de berg ook deel uitmaakt van de aarde, maar zich daar tegelijkertijd ook enigszins bovenuit lijkt te verheffen, voelt Warmond zich in een lager gelegen gebied meer thuis. Dit is niet alleen een geografische voorkeur. Het impliceert ook een voorkeur voor een daarmee samenhangende spiritualiteit, die aardser, 'vrouwelijker', eenvoudiger en minder prestatiegericht is dan de spiritualiteit die ze met bergbeklimmen in verband brengt.

\section{Ziehier het nu}

Het derde gedicht van 'Everest/Himalaya' roept een mystiek aandoende ervaring op. Er zijn enkele karakteristieken die in deze richting wijzen: tijdloosheid (r. 1-2), stilte (r. 6), het ervaren van de leegte (r. 7-8) en het gebruik van paradoxen door het hele gedicht. De geijkte categorieën van werkelijkheidsbeleving zijn weggevallen. In dit derde gedicht worden een paar grenzen overschreden die plaatsing in cen mystiek interpretatiekader rechtvaardigen, namelijk de grens tussen heden en verleden (r. 1-2) en die tussen leegte en materie (r. 7-8).

In de passage 'Ziehier het nu / terug als gister' (r. 1-2) wordt een temporele grens doorbroken. Heden en verleden vallen samen, zijn niet gescheiden, althans zo wordt het op dit moment door de dichter en de lezer beleefd. Er is geen lineaire tijdsbeleving, maar een cyclische: het nu wordt gister, het gister wordt nu enzovoorts. De uniciteit van het tijdstip is als het ware doorbroken. Heden en verleden worden even niet meer gevoeld als geïsoleerde en tegengestelde fragmenten, maar als onderling inwisselbaar. Daarmee wordt het tijdsbegrip gerelativeerd.

Het tussenwerpsel 'ziehier' vestigt de aandacht van de lezer op wat komen gaat. Bovendien wijst deze visuele aanduiding op de rol van het zien in de mystieke ervaring, die een direct inzicht met zich meebrengt dat buiten het gebied van het intellect ligt. In het eerste gedicht van de cyclus gaan 'blinden [...] kijken / of het wel waar is'. Zij gaan echter uit van het zintuiglijk zien, dat ontoereikend en zelfs misleidend is. In het derde gedicht is het zien eerder van mystieke aard. Dit 'schouwen' wordt -hoe kortstondig misschien ook- niet geblokkeerd door het dualistische denken in begrippen. Er is een beleving van een ongedifferentieerde eenheid, van non-dualisme.

Met het licht is ook iets bijzonders aan de hand. Uiteraard verwijst de dichter in eerste instantie naar het reële licht en de reële schaduw, die in de Van Dale als volgt wordt omschreven: "een donkere vorm waarin een [ondoorzichtig] lichaam zich door het onderscheppen van de lichtstralen op de bodem of op een achtergrond aftekent.' Niet het licht veroorzaakt een schaduw, maar een lichaam of voorwerp dat

14. Kristofer Schipper, Tao, De levende religie van China, Amsterdam 1989: 166; 241 
de lichtstralen onderschept. De regel 'licht werpt zijn schaduw omhoog' is een paradox.

De 'hoge' schaduw uit het derde deel van de cyclus wordt niet veroorzaakt door het onderscheppen van zonnestralen, maar van stralen van een lichţbron die zich op een laag punt bevindt. Het licht schijnt van onderaf. Maar wat voor licht is het? Een natuurkundig te verklaren licht of het licht dat mystici vaker noemen als een verschijnsel dat hun mystieke ervaringen begeleidt? Deze passage geeft zijn raadselachtigheid niet geheel en al prijs. In ieder geval bevindt het licht zich, net als de steen der wijzen, beneden. Bovendien zit er iemand gehurkt (r. 5) en meet daar de leegte, die zich dus ook daar beneden moet bevinden, voor zover je dat zo kunt zeggen. Kortom, de aandacht is net als in het tweede gedicht naar beneden gericht. De lichtervaring gaat samen met een beleving van stilte (r. 6) en leegte (r. 7-8). 'Stilte' en 'leegte' zijn termen die vaak voorkomen in het mystieke idioom. In het gedicht 'Everest/Himalaya' is de leegte niet een negatieve term die duidt op afwezigheid, ze is juist iets wat zintuiglijk waarneembaar is, zoals blijkt uit de paradoxale regels 'de leegte meten als vleselijk' (r. 7-8). De leegte wordt op dit moment als een levende aanwezigheid gevoeld. Het gebruik van de lange e-klanken versterkt het ruimtescheppende perspectief. Het begrip 'leegte' heeft hier niet de westerse invulling van 'onvervuldheid' of 'zinloosheid' in nihilistische zin. In taoïstische en boeddhistische context houdt het begrip 'leegte' verband met een relationele manier van denken. Met 'leegte' wordt bedoeld dat verschijnselen niet los van het geheel bestaan. Elementen op zich hebben geen eigen werkelijkheid, ze bestaan alleen maar in relatie tot elkaar. In de Tau Te Tsjing noemt Lao Tze de leegte een voorwaarde voor het bestaan van vormen:

van klei wordt vaatwerk gevormd,

en dank zij de ruimte waar niets bestaat,

kunnen wij ze als vaten gebruiken ${ }^{15}$

Het leegtebegrip heeft ook nog een andere inhoud. Het duidt erop, dat de ultieme werkelijkheid non-dualistisch is. Het is het reflexieve denken dat een scheiding aanbrengt in begrippen en categorieën. Via meditatietechnieken of tijdens een mystieke ervaring kun je dit dualistische denken transcenderen en de eenheid van alle dingen ervaren.

De stilte die door het woord 'bladstil' (r. 6) gesuggereerd wordt, duidt zowel op afwezigheid van geluid als op afwezigheid van beweging. Blijkbaar is het zo stil in de lucht, dat geen blad zich beweegt en daardoor dus ook geen geluid veroorzaakt. Het is opmerkelijk dat in de eerste drie gedichten van de cyclus visuele en kinetische aanduidingen overheersen, zoals onder meer blijkt uit de woorden 'blinden'. 'kijken', 'ziehier', 'komen', 'onberoerd', 'werpt', 'gehurkt' en 'meten'. In het vierde

15 Lao Tze, Tau Te Tsjing Den Haag z.j.: 19 
en vijfde gedicht echter komen vooral auditieve aanduidingen voor als 'verstaan', 'spreken', 'klokslag', 'onhoorbaar', 'oorverdovend', 'verstaanbare tekens' en 'lees hardop'. Het woord 'bladstil' werkt door zijn meerduidigheid als een scharnierpunt in deze cyclus: het geeft de overgang aan van het visuele/kinetische naar het auditieve. De stilte waar in 'Voor wie uit is op inkeer' zo naar verlangd wordt, lijkt hier eindelijk beleefd te kunnen worden.

\section{Ik gorgel met poëzie}

In het vierde en vijfde gedicht van de cyclus wordt de taal als motief geintroduceerd: 'verstaan', 'taalresten', 'spreken', 'poëzie', 'verstaanbare tekens' en 'lees hardop'. Is er een verband tussen dit taalmotief en het ervaren van stilte en leegte in het vorige gedicht?

Van alle zintuigen schijnt het gehoor het moeilijkst uit te schakelen te zijn. Talrijk zijn de verhalen van patiënten die ondanks de narcose tijdens hun operatie allerlei gespreksflarden hebben opgevangen. De dichter probeert in het vierde gedicht ontvankelijk te blijven voor de leegte en de stilte, zoals opgeroepen in het derde gedicht, maar de taal, die samenhangt met het gehoor, werkt als stoorzender. Eerst moeten allerlei taalresten, taaloverschotten opgeruimd worden: woorden die niet adequaat zijn of afleiden. Ze creëren een eigen werkelijkheid, met eigen wetten, zoals 'niemand kan dan toch spreken / met die andere niemand?' (r. 4-5). Dergelijke taalvondsten kunnen in een andere context zinnig zijn. In de Odyssee bijvoorbeeld leidt Odysseus, de vindingrijke, de cycloop Polyphemus om de tuin door zich Niemand te noemen. Als de makkers van Polyphemus vragen wie hem verwond heeft, antwoordt de reus: "Niemand!" Dank zij de hierdoor ontstane verwarring kunnen Odysseus en zijn vrienden ontsnappen.

Om toegang te kunnen krijgen tot een andere werkelijkheidsbeleving dient men zich echter te ontdoen van dit soort spitsvondigheden, omdat ze belemmerend werken. De poëzie heeft hierin een reinigende functie: 'ik gorgel met poëzie' (r. 6) en 'spuw het uit' (r. 7). Poëzie is blijkbaar een mogelijkheid om in contact te komen met die andere werkelijkheid. ${ }^{16} \mathrm{Na}$ het 'gorgelen' is de dichter weer ontvankelijk voor de stilte en de leegte: 'vul mijn oren / met stilte mijn ogen met leegte'(r. 7-8). Het lijkt: wel alsof ze eerst aan de taal en het daarmee samenhangende reflexieve denken voorbij moet zien te komen. Pas nadat dit dualistische, onderscheid aanbrengende denken dank zij de poëzie getranscendeerd is, is er plaats voor een mystiek aandoend ervaren van stilte en leegte. Het paradoxale is echter, dat Warmond alleen via de taal in staat is deze ervaring voor de lezer op te roepen. Dit gedicht is hiermee een duidelijke exponent van de moderne poëzie, aangezien het gedicht voor de moderne dichter in de woorden van Rodenko een zesde

16 als ik het in dit hoofdstuk over een 'andere werkelijkheid' heb, bedoel ik net dat er verschillende soorten werkelijkheid bestaan, maar dat een en dezelfde realiteit op verschillende mamieren beleefd kan worden. Die 'andere werkelijkheid' slat hier op een non-dualstische werkelijkheidservaring 
zintuig is waarmee hij tekens uit een andere werkelijkheid kan opvangen. ${ }^{17}$. In hoeverre dit gedicht ook thuishoort in de zogenaamd 'zuivere' traditie vind ik moeilijk te bepalen. In hoofdstuk IX gaf ik al aan, dat het zelfs voor Sötemann, die de termen 'zuivere' en 'onzuivere' traditie in Nederland introduceerde, niet duidelijk is of de poëzie=mystiek-opvatting bepalend is voor alle moderne poëzie of alleen voor de 'zuivere' traditie. ${ }^{18}$ Voor zowel de 'zuivere' als de 'onzuivere' dichter is de poëzie een middel of werktuig waarmee de onbekende essentie van het bestaan verkend kan worden. Beide soorten dichters hopen, dat het voltooide gedicht het mysterie zelf tot uitdrukking brengt. Het wezenlijke verschil tussen beide tradities is volgens Sötemann, dat de 'onzuivere' dichter zichzelf ziet als ziener en leraar. Daarmee zou de poëzie vooral voertuig worden van emoties, inzichten en geloof. Tegelijkertijd erkent Sötemann dat 'onzuivere' dichters sterk beïnvloed zijn door ideeën uit de 'zuivere' poëtica. De vraag doet zich voor in hoeverre dit onderscheid relevant is of kunstmatig is aangebracht. Van de 'onzuivere' traditie geeft Sötemann namelijk minder citaten, volgens zijn zeggen omdat 'onzuivere' dichters zich minder hebben uitgelaten over poëticale problemen. Maar hij erkent ook, dat hij met de citaten uit het werk van. Walt Whitman, exponent van de 'onzuivere' traditie, een eenzijdige, scheefgetrokken kijk heeft gegeven op diens poëzieopvatting. Sötemann beschrijft zijn werkmethode als volgt:

Bepaalde citaten moesten rigoureus ingekort worden om het effect te bereiken dat ik nastreefde, en bepaalde woorden moesten enigszins worden verdoezeld. $^{19}$

Er is op zich niets tegen een scherpe selectie van citaten om een bepaalde hypothese te ondersteunen. Nuancering leidt in dat soort gevallen alleen maar af van de hoofdstelling. De vraag is natuurlijk wel in hoeverre zo'n 'scheefgetrokken kijk' een al te vertekend beeld oplevert en in hoeverre zo'n onderzoeksmethode tot een self-fulfilling prophecy leidt. Daar komt bij, dat poëtica en poëziepraktijk van dichters niet altijd samen blijken te vallen. Het is hier niet de plaats om op deze kwesties nader in te gaan, maar het lijkt me wel raadzaam de conclusies van Sötemann met de nodige voorzichtigheid te bejegenen.

Terug naar het vierde gedicht uit 'Everest/Himalaya'. Het stiltebegrip krijgt er in dit gedicht een dimensie bij: het is niet alleen een aanduiding voor de afwezigheid van beweging en geluid, zoals in het derde gedicht, maar het geeft tevens de afwezigheid van storende taalresten en daarmee ook van storende gedachten aan. Stilte

17 zie Paul Rodenko, 'De poëzie van het 'vlies'.' In: Verzamelde essays en kritieken II. Amsterdam 1991. $249-260$

18 zie A.L. Sötemann, 'Twee modernistische tradities in de Europese poëzie. Enige suggesties.' In: Over poetict en poezic. Groningen 1985: 77-94

19 Sötemann, 1985:92 
verwijst hier dus ook naar een rustige geest, waar in 'Voor wie uit is op inkeer' zo naar verlangd wordt.

Het blijft niet bij het ervaren van stilte en leegte, er gebeurt ook iets intrigerends met de ademhaling: 'en adem achterstevoren' (r. 9). De gewone volgorde is inademen en dan uitademen. Begint de geboorte niet met een inademing? Hier is de volgorde omgedraaid. Niet het spreken, dat op de uitademing gebeurt, maar het zwijgen/de stilte wordt nu belangrijk. In de ademtherapie wordt inademen in verband gebracht met nemen en spanning, terwijl uitademen geassocieerd wordt met (zich) geven en ontspanning. In het 'achterstevoren' ademen lijkt het accent op de uitademing, op het (zich) geven en op ontspanning te liggen

Diverse dichters hebben, ieder op hun eigen manier, het ademen binnen een grotere, kosmische, context geplaatst. Bij Goethe krijgt de ademhaling een religieuze dimensie:

Im Atemholen sind zweierlei Gnaden:

Die Luft einziehen, sich ihrer entladen:

Jenes bedrängt, dieses erfrischt:

So wunderbar ist das Leben gemischt.

Du danke Gott, wenn er dich presst,

Und danke ihm, wenn er dich wieder entlässt. ${ }^{20}$

Een ander voorbeeld is het gedicht 'Ademen' van J.C. Bloem. In eerste instantie lijkt de dichter het leven te relativeren en terug te brengen tot het maxime: 'Leven is niet veel meer dan ademhalen'. Maar in de tweede strofe blijkt de adem de verbinding te zijn met de kosmos en wordt de adem zélf tot kosmisch fenomeen:

Eenzaam bevonden onder 't flonkerstralen

Der najaarssterren boven de gerust-

Geworden wereld, wordt zich ' $t$ hart bewust:

Leven is niet veel meer dan ademhalen.

Maar dat is: in de diepten van dit dal

De oneindige ruimte tot zich in te leiden 
En, na één wankel ogenblik van beiden,

Die te hergeven aan ' $t$ beroofd heelal. ${ }^{21}$

Bij Warmond duidt het 'achterstevoren' ademen erop dat de overgave, een belangrijk facet van de mystieke ervaring, centraal staat. Inademen is de wereld in je opnemen, uitademen is je overgeven aan de wereld. Op dat moment, zo blijkt uit het vijfde gedicht, wordt het eeuwige in het tijdelijke voelbaar.

Vrijwel de gehele cyclus is gebouwd op paradoxen: 'blinden gaan kijken', 'Ziehier het nu terug als gister', 'licht werpt zijn schaduw omhoog', 'de leegte meten als vleselijk', 'niemand kan dan toch spreken met die andere niemand', 'vul mijn oren met stilte', 'mijn ogen met leegte', 'adem achterstevoren', 'De grote klokslag valt hier eeuwig', 'onhoorbaar oorverdovend', 'verstaanbare tekens: wit blanco niets', en 'ik lees hardop wat ik niet uit kan spreken'. De paradox is een procédé van literaire vervreemding dat in de poëzie veelvuldig gebruikt. wordt. Deze stijlfiguur kan de lezer niet alleen nieuwsgierig maken of tot nadenken aanzetten, ze kan ook de als normaal geaccepteerde zienswijze ter discussie stellen door twee elkaar in eerste instantie uitsluitende elementen met elkaar te verzoenen. Dit literaire procédé is ook vaak aan te treffen in mystieke literatuur. Omdat de mystieke ervaring niet of nauwelijks over te dragen is, wordt de mysticus gedwongen poëtische taal te gebruiken, als hij er tenminste nog iets over wil zeggen. In de oosterse mystiek worden paradioxen vooral gebruikt om aan te tonen dat het rationele denken een relatieve, zeer beperkte geldigheid heeft. De Tau Te Tsjing bijvoorbeeld gebruikt dit procédé enerzijds om de lezer/leerling te dwingen nog eens door te denken, anderzijds om te laten zien dat pogingen tot denken en verstandelijk verklaren tot mislukken gedoemd zijn. In het taoísme is transformatie een essentieel uitgangspunt, zoals blijkt uit paradoxale uitspraken als 'wees leeg en je zult vervuld blijven' of 'wil je nemen, dan zul je eerst moeten geven'. De paradox dient ertoe om de dwingelandij van de begrippen en van vooroordelen te doorbreken. Hij toont aan wat voor tegenstrijdigheden de verbale communicatie oplevert en wat de grenzen daarvan zijn. Koans, raadselachtige zenspreuken, maken ook vaak gebruik van paradoxen. Koans zijn net als mantra's vooral bedoeld om een verandering in de geestesgesteldheid teweeg te brengen. Ze proberen het denken los te weken van de vertrouwde methoden van logisch redeneren. Een koan is niet op te lossen met

21 J.C. Bloem, Verzamelde gedichten. Amsterdam 1979:129. J. Kamerbeek vergelijkt in De poëzie van J.C. Bloem in Europers perspectief (Amsterdam 1979:75-80) dit gedicht met Rilkes 'Atmen, du unsichtbares Gedicht!', het eerste gedicht uit het tweede dee! van Die Sonette an Orpheus (1923). In 'Nijhoff, Bloem, Rilke' vraagt Kusters zich af of ook Nijhoff geïnspireerd werd door Rilkes gedicht. In een voordracht over poëzie uit 1935 stelt Nijhoff dat poëzie rekening houdt met de 'inademing'. Poèzie 'doet inademen op de levende plekken. Hiendoor ontstaat telkens een ondeelbaar moment een stilte, juist op die levende plekken, en in dit trillend oponthoud confronteren ziel en oneindigheid.' Bij poëzie voelt de mens zich 'terstond in het heelal. Elk goed gedicht bevat deze confrontatie van puur heelal en inwendigheid [...]'. (geciteerd in: De nienue taalgids 81-2, 1988: 178). Het valt buiten het kader van dit hoofdstuk om hier nader op in te gaan. 
behulp van de logica, maar is juist ontworpen om het denkproces tot stilstand te brengen en de zenleerling daarmee voor te bereiden op de non-verbale ervaring van de werkelijkheid. De verlichtingservaring gaat namelijk alle categorieën van het denken te boven. Woorden kunnen nooit de uiteindelijke werkelijkheid weergeven. $^{22}$

\section{De grote klokslag}

Het oproepen van de mystieke leegte wordt voortgezet in het vijfde deel van 'Everest/Himalaya'. 'De grote klokslag' (r. 1) overstijgt de tijd: 'valt hier eeuwig', in tegenstelling tot de kleine klokslag, die een veel geringer bereik heeft en alleen maar de uren aangeeft. De grote klokslag is de klokslag waar het om gaat, hij geeft de essentie aan. Hij duurt eeuwig en het enige wat hij aangeeft is tijdloosheid, stilte en leegte, 'onhoorbaar', maar zeer doordringend ('oorverdovend'). Evenals in het derde gedicht van de cyclus wordt hier een temporele grens doorbroken: lag in het derde deel het accent op het cyclische van de tijd ('Ziehier het nu / terug als gister') , in dit vijfde deel wordt de ondeelbaarheid van de tijd voelbaar gemaakt.

Het gedicht is gebouwd op een aantal paradoxen, die met elkaar verbonden zijn door auditieve correspondenties. Ze bevatten enerzijds een element dat geluid aangeeft en anderzijds een element dat met stilte te maken heeft:

$\begin{array}{ll}\text { GELUID } & \text { STILTE } \\ \text { klokslag } & \text { valt eeuwig } \\ \text { oorverdovend } & \text { onhoorbaar } \\ \text { verstaanbare tekens } & \text { wit blanco niets } \\ \text { ik lees hardop } & \text { niet uit kan spreken }\end{array}$

Net als in het vorige gedicht is er hier een mysterieus verband tussen stilte en taal. De volgende regels kunnen ons op een spoor zetten: 'dit [zijn] de verstaanbare tekens: / wit blanco niets' (r. 6-7). Opgevat als een reeks synoniemen benadrukt deze trits de leegte-ervaring. De onderlinge betekenisnuances wijzen er echter op dat de leegte diverse aspecten kent. Het wit, dat natuurlijk ook naar de besneeuwde top van de Everest kan verwijzen, hangt samen met de zuiverheid van de leegte. Maar het 'wit' is ook te verbinden met de taal. Zoals in de muziek de rusten niet de muziek onderbreken, maar deel uitmaken van de compositie, zo maakt het wit in de poëzie deel uit van het gedicht. Het is op zijn minst net zo belangrijk als het verbale gedeelte van het gedicht. De stilte tussen de woorden laat aan de ene kant het zegbare klinken, aan de andere kant accentueert ze het onzegbare. Het woord 'blanco' sluit daarbij aan. Ook deze term duidt op het oningevulde of nog niet ingevulde, op datgene wat opengelaten wordt. Het 'niets' lijkt me hier niet nihilis-

22 ontleend aan: Frits Staal, Het wetenschappelijk onderzoek uan de mystick. Utrecht/Antwerpen 1978:37:57 
tisch bedoeld. Het geeft aan dat de ervaring van de leegte niet te vatten is i woorden of begrippen. Alle drie de termen -wit, blanco, niets- verwijzen in dez mystiek aandoende context ook naar een non-dualistische werkelijkheidsbelevin: In het boeddhisme betekent leegte immers ook afwezigheid van onderscheid $i$ eenheid.

In dit gedicht begint zich al een scheiding af te tekenen, die in het volgende gedict gethematiseerd wordt: 'voor wie hier geboren is zijn / dit de verstaanbare tekens' . 5-6). Mensen die geboren zijn in het Everest-gebied of in de Himalaya zij vertrouwd met dit soort leegte-ervaringen, omdat die deel uitmaken van hun bele vingswereld en cultuur. De passage 'verstaanbare tekens' kan in deze context zowl auditief als mentaal worden opgevat: de tekens worden gehoord, opgevangen á begrepen. Maar geldt dat ook voor mensen die van buitenaf komen, zoљ Warmond? Het gedicht eindigt immers met de woorden: 'ik lees hardop / wat : niet uit kan spreken' (r. 8-9). Uitspreken is niet mogelijk, lezen blijkbaar wel. Aar gezien je alleen maar iets kunt lezen wat geschreven of gedrukt is, vat ik deze regø op als een verwijzing naar de poëzie. Alleen het gedicht kan het onuitsprekelijk verwoorden. Poëzie is hier, in de woorden van Rodenko, het zesde zintuig d: tekens uit het Andere op kan vangen. ${ }^{23}$

\title{
6. Gehinderd door miin bagage
}

In het zesde gedicht zijn we weer terug bij het zien. Had het kijken in het eerste deel van 'Everest/Himalaya' een negatieve connotatie ("blinden gaan kijken / of het wel waar is'), in dit laatste gedicht geeft het kijken het hoogst bereikbare aan:

\author{
De horizon \\ bijna aanraakbaar \\ ten minste met de blik
}

De horizon, de lijn waar hemel en aarde elkaar lijken te raken, is geen vast punt waar iemand uiteindelijk bij uit kan komen. Als de kijker zich verplaatst, verplaatst de gezichtseinder zich ook. Ze zullen elkaar nooit ontmoeten. Hoewel, in het zesde gedicht lijkt de dichter iets anders te suggereren: 'De horizon / bijna aanraakbạar', Er volgt echter meteen een restrictie: 'ten minste met de blik'.

In deze passage klinken verschillende betekenissen van 'horizon' tegelijkertijd door. Het woord verwijst niet alleen naar de gezichtseinder, de begrenzing van het blikveld, maar ook naar de geestelijke horizon, het gebied dat de geest of het verstand kan overzien. De ervaring uit de vorige gedichten van de cyclus heeft de geestelijke horizon blijkbaar zodanig verruimd, dat hij 'bijna aanraakbaar' lijkt. De dichter twijfelt er echter aan of volledig contact mogelijk is: 'maar kan ik dat als ik wil?' (r. 
4). Met deze opmerking plaatst Warmond zich in de traditie van de dichters van het 'vlies'. Deze dichters ervaren een heel dun vliesje tussen de alledaagse realiteit en het Andere. Enerzijds is dit een echec, anderzijds een triomf, omdat ze er wel in geslaagd zijn, al is het maar voor even, deel te hebben aan dit Andere. ${ }^{24}$ Net als de horizon lijkt het Andere bereikbaar, maar wijkt het als je het nadert.

Warmond plaatst dit echec in een cultuur-historische context. Er is een kloof, om in alpinistische termen te blijven, tussen twee culturen. In het oosten behoort zo'n ervaring van het Andere tot de mogelijkheden: 'voor wie hier geboren is zijn / dit de verstaanbare tekens', zoals in het vijfde gedicht van 'Everest/Himalaya' staat. Maar de dichter voelt zich:
gehinderd door mijn bagage
waar de dragers geen weet van hebben:
de grijns van de Mona Lisa
Cleopatra's diademen
de luidsprekers van Hitler
en het slijk van Hollandse polders
Calvijn in het grondwater roeiend

De dragers dragen alle reisbenodigdheden, maar Warmond torst zelf haar cultureel-historische bagage met zich mee, waardoor ze zich van hen gescheiden voelt: schilderkunst, klassieke en contemporaine geschiedenis, de niet bepaald verfijnde Nederlandse cultuur en het calvinisme. De enumeratie in r. 7-11 representecrt een totaal andere wereld dan die het oosten bij Warmond oproept. Zo vormen de 'luidsprekers van Hitler' een scherp contrast met de stilte en sereniteit die in de vorige gedichten zo'n grote plaats innamen.

Er is ook een landschappelijk contrast: de keurig ingedamde Hollandse polders steken mager af tegen het majestueuze, grillige berglandschap van de Himalaya. Bovendien vormt het drassige poldergebied een scherp contrast met de hardheid en stevigheid van de bergen. Blijkens de beeldspraak in r. 10-11 heeft de dichter een negatief beeld van Nederland en het Hollandse calvinisme. Roeien in grondwater is nogal moeizaam. Dit beeld en het beeld van de drassige polder zouden kunnen duiden op een gebrek aan geestelijke diepgang of op de belemmerende en inperkende invloed die het calvinisme kan hebben op het zieleleven. Al eerder gaf Warmond een niet zo vleiend beeld van de doorsnee-Nederlander, die herkenbaar is aan:

24 zic Paul Rodenko, 'De poëzie van het 'vlies'. In: Verzamelde essays en kriticken II, Amsterdam 1991: 249-260 
zijn neergetrokken mond

en aan zijn ingeschapen weerzin om zowel

het lichaam als de geest eens te bewegen ${ }^{25}$

De scheiding die Warmond in het laatste gedicht van 'Everest/Himalaya" ervaart culmineert in de volgende gedachte:

hier kun je voornamelijk denken:

ik hoor hier niet.

Omdat oost en west in dit gedicht bij elkaar komen verliest het bijwoord' 'hier'zijr eenduidigheid: verwijst het naar de Himalaya of naar Nederland? En hoe zit he met het werkwoord 'horen'? Is dat een auditieve aanduiding of betekent het hie: 'ergens deel van uitmaken' of 'thuishoren'? Ik vermoed dat al deze mogelijkhedet een rol spelen in die intrigerende laatste regels. De dichter beseft, dat ze niet thuis. hoort in de Himalaya, ze kan geen deel uitmaken van de bijbehorende cultuu Maar gezien de beschrijving in r. 10-11 voelt ze zich ook niet thuis in Nederland In eigen land verlangt Warmond naar de stilte-ervaring die in het Himalayagebiec wel mogelijk was. Er is echter een probleem: Nederland is in tegenstelling tot he oosterse berglandschap niet de geschikte omgeving om de signalen uit die ander werkelijkheid, waarvan het middendeel van de cyclus rept, te horen of op te vangen. Ook dat maakt dat ze zich in Nederland niet thuis voelt.

Met de regel 'ik hoor hier niet' wordt iets afgesloten, wat in de mystieke ervaring juist zo belangrijk is, namelijk de auditieve sensatie van de stilte (zie het vierde gedicht: 'en vul mijn oren / met stilte'). De andere realiteit wordt toegedekt. De dichter is weer terug in een werkelijkheid die gekenmerkt wordt door scheiding, verdeeldheid en lawaai, ze is weer terug bij af. De situatie lijkt op het slot van 'Voor wie uit is op inkeer 2 ', waarin het lyrisch subject tevergeefs verlangt naar geestelijke rust:

mooi moet dat zijn maar hier ter plaatse

welhaast niet haalbaar

door iedere gedachte aan niets

rijdt met knersende remmen een tram.

Er is echter een belangrijk verschil: de stilte-ervaring en het beleven van een andere werkelijkheid blijkt, ook al is het maar voor even, wel degelijk mogelijk.

25 uit: 'Eenheid van tijd (een theatral beginsel)' in: De groeten aan andersdenkenden. Amstendam 1970: $29-31$ 
De tweeledige titel van de cyclus weerspiegelt het verschil tussen oost en west. De Sherpa's hebben voor de Everest een eigen naam: Chomoloengma ofwel 'goddelijke moeder van de aarde'. De berg werd in 1856 door de 'Ground Survey of India' vernoemd naar Sir George Everest, gepensioneerd 'Surveyor-General of India'. Dit gebeurde vijftien jaar nadat de Engelsen ontdekten dat dit de hoogste berg van de wereld is. Tot die tijd moest de berg het doen met de aanduiding 'Peak XV'. Sir Everest was uit politieke overwegingen niet zo gecharmeerd van het idee om de berg naar hem te vernoemen. De afspraak was om een officieel in kaart gebrachte berg de naam te geven waaronder hij bij de plaatselijke bevolking bekend stond. Maar Sir Andrew Waugh, de opvolger van Everest, dreef zijn zin door en kreeg voor elkaar dat de berg toch naar Everest vernoemd werd. ${ }^{26}$

Er is een scherp contrast tussen de sherpanaam en de westerse aanduiding 'Mount Everest'. In de sherpanaam is de aandacht gevestigd op de verbinding van het kosmische ('goddelijke moeder') met het aardse. In de westerse naam daarentegen is de aandacht gericht op de top, het 'verdere', het 'hogere'.

Waarom noemt Warmond dit gedicht eigenlijk 'Everest/Himalaya'? De laatste toevoeging lijkt overbodig, want wie weet nu niet dat de hoogste berg zich in de Himalaya bevindt? Er moet iets anders aan de hand zijn. De titel bergt een verrassend contrast in zich. In de vernoeming naar een persoon komt het westerse individualisme naar voren, terwijl de term Himalaya, 'domein van de sneeuw', de eenheidservaring benadrukt. 'Everest' is symbool voor het individu dat -ook al is het maar voor even- teruggeplaatst wordt in de eenheid, die op haar beurt gesymboliseerd wordt door de Himalaya. Enerzijds verbindt de schuine streep in de titel beide elementen met elkaar, anderzijds brengt hij een scheiding aan. Kortom: de thematiek van de cyclus in een notendop.

'Everest/Himalaya' zit vol ruimtelijke aanduidingen die te maken hebben met 'boven' en 'beneden'. Afgaande op dit soort aanwijzingen zou je de structuur van de cyclus kunnen visualiseren als een berglandschap. Uiteraard zijn de afstanden tussen boven en beneden niet exact te bepalen; ook de lijn van de horizon is in dit geval lastig te visualiseren. Het schema wil alleen maar weergeven dat er een afwisseling is tussen boven en beneden en dat het zoeken naar wijsheid in de visie van de

26 ontleend an: Walt Unsworth, Everest. The Ultimate Book of the Ultimate Mountain. London 1991: $546-550$ 
dichter eerder 'beneden'(in relatieve zin) moet plaatsvinden dan boven (ook in rela tieve zin).

I hoger

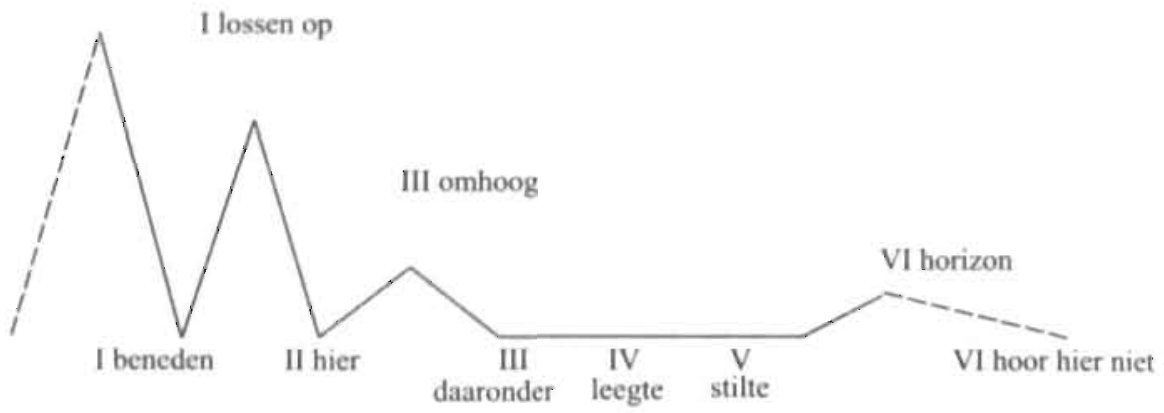

Gedichten waarin landschappen en klimaten een mentale gesteldheid weerspic gelen bevatten vaak transgressiemotieven. ${ }^{27} \mathrm{Ze}$ gaan bijvoorbeeld over pooltochte! het beklimmen van bergen, het onderzoeken van barre streken, het afdalen in d warde en in de dienzee. Ook het verlaggen te kunnen vliegen hoort daarbii. Dez motieven worden tot transgressiemotieven als ze tegelijkertijd verband houden met de leegte als filosofisch/religieus begrip, eeuwigheidsverlangen, het opheffen van de tijd, streven naar taalzuiverheid en aardse metafysica. ${ }^{28}$ Hoewel Warmond niet voor het bergbeklimmen kiest, is er in de 'Everest/Himalaya-cyclus duidelijk sprake van een transgressiemotief. Het derde, vierde en vijfde gedicht, waarin de mystieke ervaring wordt opgeroepen, zijn 'beneden' gesitueerd. Dit sluit aan bij wat in het tweede gedicht al werd aangekondigd: 'Hier [beneden] ligt de steen der wijzen / voorgoed verankerd in de grond'. Hier is sprake van een aardse transcendentie: wijsheid hoef je niet ver te zoeken, zij bevindt zich 'beneden', als het ware onder handbereik ('voor iedereen toegankelijk'). Uiteraard kan het beklimmen van bergen ook: een vorm van aardse transcendentie zijn, de berg maakt immers deel uit vạn de aarde. Warmond onderscheidt echter twee vormen aardse transcendentie: enerzijds een vorn die veel inspanning vereist (het klimmen), anderzijds een vorm die relatief weinig inspanning vraagt (het aanraken van de steen der wijzen). Zij opteert voor de laatste mogelijkheid, want, zoals ze elders zegt: 'het ware inzicht ligt diep beneden' 29

27 'transgressie' wordt her gebruikt in de neutrale betekenis van; 'oversteken', 'passeren'.

28 ontleend an Wiel Kusters, Pooltochten. Amsterdam 1989

29 uit: 'Denken'. In: Gesloten spiọvels. Amsterdam 1979: 17 


\section{Mystiek}

Uit de analyse van 'Everest/Himalaya' blijkt, dat diverse elementen wijzen op een mystiek aandoende ervaring. Maar impliceert dit dat deze cyclus opgenomen kan worden in de canon van mystieke gedichten of, met andere woorden, komen deze aanwijzingen overeen met de criteria die Van de Watering heeft opgesteld voor mystieke literatuur? Wat de inhoudelijke component betreft, lijkt me dat met name in het middendeel van de cyclus het geval. Er is sprake van een eenheidsbeleving, aangezien de leegte hier geinterpreteerd kan worden als de afwezigheid van het dualistische, onderscheid aanbrengende denken. Deze ervaring bevat een ken-aspect, namelijk dat het beleven van de eenheid mogelijk is in het hier en nu. Of de ervaring de dichter overkomt, is niet expliciet uit de tekst op te maken, maar het lijkt me wel waarschijnlijk. De laatste regel van het vierde gedicht ('en adem achterstevoren') interpreteerde ik als een vorm van overgave. Hoewel overgave meestal -wat mij betreft ten onrechte- als iets passiefs gezien wordt, lijkt ze me hier juist het resultaat van een zich actief bevrijden van taalresten: 'ik gorgel met poëzie / spuw het uit' (IV r. 6-7). Pas dan kan de dichter zich openstellen voor de leegte: 'en vul mijn oren / met stilte mijn ogen met leegte'.

Dit ontvankelijk zijn voor de stilte en de leegte is een kenmerk van een ander ik-bewustzijn, dat niet samenvalt met het alledaagse ik-besef. Bovendien wordt er geen temporele grens meer ervaren ('Ziehier het nu / terug als gister') en is er sprake van een eeuwigheidsbeleving ('De grote klokslag/ valt hier eeuwig'). Wat de mededeelbaarheid van de ervaring betreft, doet zich een paradoxale situatic voor: alleen het gedicht blijkt het onuitsprekelijke te kunnen verwoorden.

Wat de formele/literaire component betreft, levert 'Everest/Himalaya' een bijdrage aan het mystieke lexicon van bijzondere uitdrukkingsvormen en -middelen. In de analyses van de diverse onderdelen werd hier al aandacht aan besteed. Opmerkelijk is het aantal paradoxen en de verscheidenheid daarvan. Met name de zintuiglijke paradoxen vallen op: auditief (bijvoorbeeld 'vul mijn oren met stilte'), visueel (bijvoorbeeld 'blinden gaan kijken') en tactiel (bijvoorbeeld 'de leegte meten als vleselijk'). Daarnaast zijn er een paar paradoxen die met de taal te maken hebben, bijvoorbeeld 'de verstaanbare tekens: / wit blanco niets' en 'ik lees hardop / wat ik niet uit kan spreken.' Deze paradoxen ondermijnen de als normaal geaccepteerde zienswijze en tonen aan dat het rationele denken een relatieve, beperkte geldigheid heeft. Bovendien verwijzen ze door hun ambiguiteit naar een andere werkelijkheidsbeleving.

Een andere bijdrage aan het mystieke lexicon zijn de diverse beelden die Warmond gebruikt om de stilte mee op te roepen: "bladstil", 'de leegte', het kwijtraken van taalresten, 'de grote klokslag / valt hier eeuwig', 'onhoorbaar / oorverdovend' en 'wit blanco niets'. De stilte is bij Warmond overigens veelzijdig. Ze krijgt zowel een auditieve, kinetische als mentale invulling: afwezigheid van geluid, afwezigheid van beweging en afwezigheid van storende gedachten. 
In de canon van transgressiemotieven neemt Warmond een heel eigen plaats in. Ze is niet prestatiegericht. Voor haar geen verafgelegen en moeilijk bereikbare gebieden. Haar spiritualiteit is niet 'mannelijk', dat wil zeggen gericht op 'hoger, verder, meer'. ${ }^{30}$ In hoeverre hier inderdaad sprake is van een gendercomponent, kan ik in dit stadium nog niet aangeven. Daartoe zullen eerst mystieke gedichten van mannelijke en vrouwelijke dichters nader onderzocht en onderling vergeleken moeten worden.

Met wat voor soort mystiek hebben we in 'Everest/Himalaya' te maken en is er een verschil tussen oosterse en westerse mystiek? Om te beginnen met de laatste vraag: ten onrechte wordt vaak een onderscheid aangebracht tussen oosterse en westerse mystiek. Christelijk denken zou dynamisch en creatief zijn, omdat het de werkelijkheid en de zinvolheid van het leven bevestigt. Hindoeisme en boeddhisme zouden geen creatieve kracht kennen, omdat ze de werkelijkheid ontkennen en dood en onbeweeglijkheid verheerlijken. In westerse mystiek zou de affirmatie van de wereld en het leven centraal staan, terwijl oosterse mystiek juist van de negatie van wereld en leven uitgaat. Oosterse mystiek wordt tegen de profetische religies afgezet als passief, berustend en contemplatief, terwijl de profetische religie actief, verlangend en ethisch zou zijn. In mystiek zou het ik ontkend worden in tegenstelling tot profetische religies waarin het ik juist bevestigd wordt. Tenslotte zou mystiek vrouwelijk zijn en de profetische religie mannelijk.

$\begin{array}{ll}\text { vermeende verschillen oosterse en } & \text { westerse mystiek } \\ \text { OOSTERSE MYSTIEK } & \text { WESTERSE MYSTIEK } \\ \begin{array}{ll}\text { negatie } & \text { affirmatie } \\ \text { passief } & \text { actief } \\ \text { berustend } & \text { verlangend } \\ \text { contemplatief } & \text { ethisch } \\ \text { ontkenning van het ik } & \text { bevestiging van het ik } \\ \text { vrouwelijk } & \text { mannelijk }\end{array}\end{array}$

Deze twee typen vind je echter allebei zowel in het oosten als in het westen. In feite is er ook geen sprake van een tegenstelling, maar van fases waarin het een of het ander wat meer benadrukt wordt. Het boeddhisme bevat ook een ethische component, aangezien Boeddha het belangrijk vond dat iedereen op actieve en systematische wijze zachtmoedigheid cultiveert. De christelijke eschatologie bevat ook een zekere negatie door te stellen dat het Koninkrijk Gods niet hier op aarde gevestigd zal worden. Bepaalde vormen van christendom legden de nadruk op contemplatie en waren niet zozeer op het leven hier en nu gericht maar op de eindtijd. Ascese, flagellantisme en langdurig vasten komen in allerlei religies voor als methoden om

30 uiteraard wil ik hiermee niet beweren dat elk mannelijk mens prestatiegericht is en uit is op "hoger. verder, meer', alleen max dat zo' $n$ houding in onze westerse cultuur al dan niet terecht als 'mannelijk' gekwalificeerd wordt. 
het lichaam onder controle te krijgen. Kortom, het contrast is niet geografisch bepaald. $^{31}$

Met het onderscheid tussen oost en west kunnen we dus niets beginnen. Om te kunnen bepalen met welke soort mystiek we dan wel in 'Everest/Himalaya' te maken hebben, maak ik gebruik van een indeling die Bruno Borchert (1994) heeft aangebracht. ${ }^{32}$ Hij onderscheidt vijf soorten mystieke ervaringen, afhankelijk van de prikkel waar ze door zijn opgewekt:

\begin{tabular}{|c|c|c|}
\hline prikkel & noorbeeld & soort mystiek \\
\hline religie & bijbel, goeroe & theistische mystiek \\
\hline natuur & tuin, landschap & natuurmystiek \\
\hline culturele omgeving & kunst, architectuur & moderne mystiek \\
\hline medemens & oorlogsslachtoffers & dialogische mystiek \\
\hline het eigen ik & $\begin{array}{l}\text { verlangen naar dieper } \\
\text { bewustzijn }\end{array}$ & wezensmystick \\
\hline
\end{tabular}

De theistische mystiek ontstaat door een religieuze prikkel als de liturgieviering, het lezen in de bijbel, contact met een goeroe of een bepaald kerkelijk dogma. Het inzicht dat God óók mens is, veroorzaakte bijvoorbeeld bij Hadewijch een mystieke ervaring.

In de natuurmystiek kan een landschap het gevoel versterken opgenomen te zijn in een groot geheel. Dit kan tot een gevoel van geborgenheid leiden, maar ook tot huiver voor de enorme grootheid van de kosmos. Volgens William James is dit de meest voorkomende vorm van mystiek. De meeste ervaringen vinden plaats in de natuur en vooral in bepaalde jaargetijden: voorjaar en vroege zomer. ${ }^{33}$ Een voorbeeld van natuurmystiek is het Zonnelied yan Franciscus van Assisi.

De moderne mystiek is vooral te vinden in eigentijdse mystieke getuigenissen en bij moderne schrijvers, aldus Borchert. Deze vorm van mystiek kent weinig affiniteit met de westerse religie, maar des te meer met de Japanse zen-mystiek, aangezien ook daar culturele bezigheden, bijvoorbeeld de theeceremonie en tuinaanleg. worden gebruikt om iemand ontvankelijker te maken voor mystieke ervaringen. Gedichten, schilderijen, muziek of een kerk zijn voorbeelden van prikkels die tot moderne mystiek kunnen leiden.

Een ontmoeting met iemand die in een uitzichtloze situatie verkeert, kan een transformerend effect hebben. Dan is er sprake van dialogische mystiek. Zo veranderde het leven van Gandhi radicaal na de ontmoeting met een klassenloze paria in de

31 deze gegevens zijn ontleend aan: S. Radhakrishnan, Eastern Religions and Western Thought. Oxford 1939: $64-76$

32 Bruno Borchert, Mystiek. Het verschijnsel, de geschiedenis, de nieuwe uitdaging. Haarlem 1994 (tweede, bijgewerkte druk), p. 22-26. De voorbeelden bij de verschillende soorten mystiek zijn ook hieraan ontleend.

33 William James, The Varieties of Religious Experience. A Study in Human Nature. New York 1999 (eerste editie 1902) : $429-434$ 
wachtkamer van een station. De vele slachtoffers die de Eerste Wereldoorlog maakte, zetten ook veel mensen aan het denken. Het belangrijkste mystieke werk uit die tijd is Martin Bubers Ich und Du (1923), aldus Borchert. In de bevrijdingstheologie in Zuid-Amerika wordt de Ander of God in de onderdrukte medemens gezien. Ook dat is een vorm van dialogische mystiek.

Wezensmystiek tenslotte komt voort uit het verlangen dieper in het eigen bewustzijn door te dringen of uit het besef dat God bereikbaar is in het diepste van ons wezen. In bepaalde tradities wordt in dit verband gesproken over de goddelijke vonk. Deze mystiek speelde ook al een rol in het vroege christendom. Een ander voorbeeld is de inkeringsmystiek van Jan van Ruusbroec (1293-1381). Het uitgangspunt is, dat we allemaal verbonden zijn met God of het goddelijke. God sprak immers ' $\mathrm{Nu}$ gaan we de mens maken als beeld van ons, op ons gelijkende' (Genesis I, 26). Dat eeuwige Oerbeeld van vóór de schepping draagt ieder mens als een gegeven met zich mee, daarom kunnen we in onze ziel één worden met God. Ruusbroec maakt een onderscheid tussen de in de Genesispassage gebruikte begrippen 'beeld' en 'gelijkenis'. Het beeld is een gegeven, of je wilt of niet. Door je manier van leven kan de gelijkenis met dat beeld groter worden of ongerealiseerd blijven. Daar is de mens vrij in, aldus Ruusbroec. ${ }^{34}$

Uitgaande van Borcherts prikkeltaxonomie concludeer ik dat 'Everest/Himalaya' een voorbeeld van natuurmystiek is. Landschap en atmosfeer evoceren en versterken de ervaring van tijdloosheid en non-dualiteit. Dat juist het landschap hier de prikkel is, blijkt ook uit de suggestie in het laatste gedicht van de cyclus dat Warmond Nederland minder geschikt acht om zo'n ervaring op te wekken.

34 zie Paul Mommaers en Jan van Bragt, Ruusbrvec in gesprek met het Oosten. Mystick in boeddhisme on christendom. Kampen 1995: 169-172 


\section{EINDCONCLUSIE}

In dit boek stonden proza en poëzie van Ellen Warmond centraal en hun relatie tot het literaire existentialisme. Diverse vragen werden opgeworpen en -waar mogelijk- ook beantwoord. Het wordt tijd om de balans op te maken. Ik geef een overzicht van de belangrijkste conclusies en doe hier en daar voorstellen voor verder onderzoek.

Het existentialisme is in Nederland vlak na de oorlog niet alleen bij filosofen en theologen maar ook bij schrijvers al bekend en populair. Conclusies over omvang en periodisering van het literaire existentialisme in Nederland zijn pas mogelijk als aan een drietal voorwaarden is voldaan: allereerst dient er onderzoek te worden verricht aan de hand van een adequate definitie; ten tweede dienen niet alleen genres als roman en toneel onderzocht te worden maar ook poëzie; ten derde moet onderzocht worden of het literaire existentialisme in Nederland dezelfde periode omvat als in Frankrijk (1935-1960) of dat er sprake is van een vertragingseffect.

Een adequate definitie van het literaire existentialisme dient zowel een inhoudelijke als een formele component te bevatten. Voor de inhoudelijke component heeft Van Stralen (1996) de nodige elementen aangedragen, terwijl Kern (1970) dat heeft gedaan voor de formele component.

Ik stel voor zowel het conflictmodel van Sartre als het ambiguïteitsmodel van Merleau-Ponty in de inhoudelijke component op te nemen. Beide modellen presenteren een visie op belangrijke aspecten als pre-reflexiviteit, reflexiviteit, lichamelijkheid, de blik, vervreemding, sexuele intimiteit en vrijheid. Deze twee modellen vervangen niet de ethische en de esthetische variant van het literaire existentialisme. Afhankelijk van de houding ten aanzien van bovengenoemde aspecten kan er zowel binnen de ethische variant als binnen de esthetische variant sprake zijn van een conflict- of een ambiguïteitsmodel.

Paspoort voor niemandsland (1961) en diverse gedichten van Warmond komen zowel inhoudelijk als formeel overeen met de kenmerken van het literaire existentialisme. Haar werk vertoont niet alleen affiniteit met het conflictmodel van Sartre maar ook met het ambiguitteitsmodel van Merleau-Ponty. Kenmerkend is een spanningsveld tussen de Sartriaanse vervreemding en een Merleau-Pontyaans verlangen naar eenheid en verzoening. De pre-reflexieve ervaring van eenheid is wel degelijk af en toe mogelijk, namelijk in de erotiek en in de mystieke ervaring. De vraag of hier sprake is van een genderfactor kan pas beantwoord worden nadat op basis van de boven genoemde voorwaarden een corpus van existentialistische romans, toneelstukken en gedichten uit de jaren ' 40 , ' 50 en ' 60 van zowel mannelijke als vrouwelijke auteurs is geanalyseerd.

Wat is Warmonds bijdrage aan het literaire existentialisme? Ten eerste laat haar werk zien dat het conflictmodel van Sartre ten onrechte als het enige existentialistische basismodel naar voren is geschoven. Ten tweede heeft Warmond de invulling van het existentialistische vrijheidsthema verruimd door de vermenging van 
sexuele identiteit en gender. Diverse personages zijn namelijk niet eenduidig te classificeren als homo/hetero of als mannelijk/vrouwelijk. In haar roman lopen categorieën als homo/hetero en/of mannelijkheid/vrouwelijkheid op een vanzelfsprekende en speelse manier door elkaar. Diverse personages vertonen een vermenging van homo- en hetero-erotiek (bijvoorbeeld Hans Erkelens, Bert Masson en Esther Engelrijk) en/of van mannelijkheid en vrouwelijkheid (bijvoorbeeld Esther Engelrijk en Jacques de la Rive). In haar poëzie is de sekseneutraliteit op te vatten als een 'genderspel', dat aangeeft, dat Warmond zich niet aan de bestaande gendercodes wenst te houden. Een grotere interpretatievrijheid voor de lezer is een bijkomend effect.

Het na 1970 toegenomen politieke engagement in Warmonds werk impliceert geen breuk met de existentialistische thematiek, aangezien er ook al vóór die tijd politiek geëngageerde gedichten in haar werk voorkomen. Het heeft hoogstens wat meer accent gekregen.

Het laatste deel van dit boek ging in op het 'transgressiemotief' in het werk van Warmond. In de canon van 'transgressiemotieven' blijkt zij een originele positie in te nemen: Warmond richt zich niet op verafgelegen en moeilijk bereikbare geografische gebieden. Haar spiritualiteit is niet gericht op 'hoger' en 'verder", maar op 'beneden' en 'dichterbij'. Pas als 'transgressiegedichten" van mannelijke en vrouwelijke dichters nader onderzocht en onderling vergeleken zijn, kan vastgesteld worden of een keuze à la Warmond genderbepaald is of niet.

In de laatste hoofdstukken kwam het mystieke verlangen naar eenheid en zuiverheid in het werk van Warmond aan de orde. Impliceert dit verlangen een breuk met het aards gerichte existentialisme? Het lijkt me dat filosofen en theologen geschikter zijn om deze vraag te beantwoorden dan neerlandici. Toch wil ik met enige schroom een poging wagen.

In het werk van Warmond spelen enkele met elkaar samenhangende thema's een. rol die in dit verband interessant zijn: vervreemding, de wens te ontsnappen aan een controlerende en inperkende rationaliteit en het verlangen naar herstel van het contact met de ander en de wereld. Deze thematiek plaatste ik in de voorafgaande hoofdstukken in een existentialistische context. Vervreemding ontstaat door een spanningsveld tussen het menselijke verlangen naar eenheid en de als zinloos ervaren wereld. In het Sartriaanse conflictmodel is vervreemding niet op te heffen, het reflexieve en pre-reflexieve bewustzijn worden als essentieel verschillende en onverzoenlijke ervaringsniveaus opgevat. In het ambiguïteitsmodel van Merleau-Ponty daarentegen is verzoening geenszins uitgesloten. Een direct en primair contact, waarin geen breuk meer wordt ervaren tussen subject en wereld, is wel degelijk mogelijk. Ervaringen van kunstenaars, kinderen en mensen uit diverse niet-westerse culturen getuigen daarvan. 
Bij Warmond klinkt in het vervreemdingsthema altijd een verlangen door naar eenheid of naar de ander, hoe subtiel. en indirect de signalen daarvan soms ook verborgen mogen zijn. In het gedicht 'Vereenvoudigde religie' bijvoorbeeld lijkt het lyrisch subject een hoge graad van vervreemding bereikt te hebben, totdat ineens aan het slot van het gedicht de woorden 'brief' en 'envelop' verschijnen als signalen van het verlangen naar contact: open mij en lees me.

Een ander belangrijk thema in het werk van Warmond is het verlangen zich te bevrijden van een controlerende rationaliteit, die een spontane, pre-reflexieve lichaamsbeleving in de weg staat. Door het reflexieve of tweedegraads bewustzijn ervaren we een onderscheid tussen subject en object, tussen onszelf en de wereld om ons heen. Tijdens momenten van vervreemding, waarin het tweedegraads bewustzijn overheerst, wordt het lichaam als object ervaren, terwijl in de pre-reflexieve ervaring het lichaam als subject kan worden beleefd. In de roman Paspoort voor niemandsland is met name de sexualiteit een mogelijkheid om tot een pre-reflexieve beleving te komen. De hoofdpersoon, Hans Erkelens, spreekt in dat verband over de 'chinese momenten', momenten waarin hij even loskomt van tijd en ruimte en zich verzoend voelt met de wereld om hem heen.

In haar poëzie speelt het verlangen naar de directheid van de pre-reflexieve ervaring, zonder tussenkomst van een reflecterend en rationaliserend $\mathrm{lk}$, een belangrijke rol. Warmond gebruikt allerlei literaire middelen om zo'n ervaring of het verlangen daarnaar op te roepen: infinitiefconstructies waarin het subject afwezig is ('de huid vanzelfsprekend bewonen'), beelden voor het pre-verbale ('ongeletterde tanden') en signaalwoorden als 'eenvoudig', 'vanzelfsprekend', 'probleemloos', 'zorgeloos', 'natuurlijk', 'onvatbaar', 'terugkeer' en 'oorsprong'.

Opheffing van vervreemding, loskomen van een controlerende rationaliteit, een unificerende werkelijkheidsbeleving: het zijn elementen die ook de mystieke ervaring kenmerken. Afgescheidenheid maakt -ook al is het maar voor even- plaats voor verbondenheid. De mystieke ervaring in 'Everest/Himalaya' is niet verheven geestelijk, maar aards gericht. Het lichaam wordt niet ontkend, integendeel. Er zijn juist allerlei met de mystieke beleving samenhangende zintuiglijke gewaarwordingen: 'vul mijn oren met stilte' en 'mijn ogen met leegte' (IV 7-8), terwijl de leegte zelfs 'als vleselijk' (III 8) wordt ervaren. Zowel 'stilte" als 'leegte' duiden hier op een non-dualistische ervaring, waarin het onderscheid tussen geluiden en dingen -tijdelijk- is opgeheven. Kortom: spontane directheid, opheffen van vervreemding en ontstijgen aan een controlerende rationaliteit zijn in het werk van Warmond niet alleen mogelijk in de sexuele ontmoeting, maar ook in de mystieke ervaring. In beide gevallen is de ander belangrijk als deelgenoot:

1 zie voor een uitgebreide analyse van dit gedicht hoofdstuk VI 
Wat wil je dan? de bergtop?

de inkeer

de zuiverheid

ik-loos?

tot iedere prijs

maar dan daarbij

een ander om

het (mee) te delen. ${ }^{2}$

2 uic: 'De snelkookpan van de tajd 8", In: Implosie. Amstendam 1976:50 


\section{SUMMARY}

In this book research is carried out into Ellen Warmond's work in relation to literary-existentialism. The first two chapters deal with the problems concerning definition and time-span of this literary-philosophical 'movement'. In chapters III $V$ attention is focused on. Warmond's novel, Paspoort voor Niemandsland (1961), not for its literary qualities, but because of its high literary-existentialist content. Moreover, the novel can help to explain the poetry, and vice versa. Warmond's poetry is discussed. in detail in chapters VI- XI.

\section{Chapters I- II Literary-existentialism}

Shortly after the second world war existentialism was popular with theologians, philosophers and writers in the Netherlands. Initially, the interest was for existentialist texts which were connected with the war and it was only later that novels such as L'Étranger (Camus) and La Nausée (Sartre) were translated. The dichtomy between, on the one hand, an existentialism of loneliness and despair and, on the other hand, a later development of an existentialism of moral choice is incorrect, being as Sartre had, in 1944, stressed the liberty and responsibility of the individual.

Reaching conclusions concerning the magnitude and time-span of literary-existentialism in the Netherlands is only possible when three conditions have been met: first of all research must be carried out based on an adequate definition; secondly, not only should novels and plays be looked at but also poetry, and thirdly, research should show whether literary-existentialism started later (and also ended later) in the Netherlands than in France.

An adequate definition of literary-existentialism is not only connected with the content but also with the form. Apart from focussing on elements such as borderline situations (viz. a difficult situation in which a person is confronted with him or herself and is therefore forced to make a choice), the other person as a catalyst, engagement and enclosed spaces, attention must also be paid to the form: a range of what are mostly modernist techniques which also make the problems apparent. Examples of this being the perspective techniques, a variation in philosophical and literary passages, simultaneity, irony and paradox.

My proposal would be to inclụde both Sarțeè's conflict model and Merleau-Ponty's ambiguity' model in the definition, being as both are connected with a difference in attitude concerning important aspects such as pre-reflectivity, reflectivity, corporality, the look, alienation, sexual intimacy and liberty. Generally speaking, in contrast to Sartre's conflict model, reconciliation and reciprocity are central to the ambiguity model. Both models could be found in both the ethical and the aesthetic variant. In the ethical variant the emphasis is on the wish to change that which is seen as the unjustified reality. The aesthetic variant, also known as the existentialism of the art of living, stresses the acceptance of reality with all its negative and positive aspects. This, however, does not exclude social and political involvement. 
The relation between literature and philosophy is complex, especially in a literary-philosophical 'movement' such as the literary-existentialism. In this book I have used the hermeneutic model to study Warmond's work, viz, the literary work is clarified for the reader by using certain philosophical terms without endangering the autonomy of literature. Contents and literary style are, as far as possible, studied in relation to each other.

\section{Chapters III - V Paspoort voor Niemandsland}

Warmond's first and only novel, Paspoort voor Niemandsland (1961), meets the criteria for literary-existentialism, both contextually and formally. The strong unity between form and content is apparent from the wide range of literary techniques which also uncover the existentialist issues. This novel belongs to the aesthetic variant of literary-existentialism. It is remarkable that not a single one of the book's reviewers associate it with existentialist issues, although the connection with the problems of the postwar youth was made. It wasn't until 1984 that Jan van der Vegt in an article on Warmond's poetry links her work to existentialism.

\section{Chapters VT - VTII Existentialism and Poetry"}

It is useful to study poetry, especially that of Warmond, from a literary-existentialist perspective. Themes such as fear, alienation, borderline situations, the personification of objects, enclosed spaces and a secularised interpretation of Christian concepts point to an affinity with the existentialist range of thought. This is also shown in the representation of the body. The perception of the body as subject (Leib) or as object (Körper) appears to be connected with the pre-reflective and the reflective consciousness respectively. Sartre's view of love as a game with a conqueror and a conquered cannot be found in Warmond's work.

Both her novels and her poetry show not only affinity with Sartre's conflict model but also with the ambiguity model of Merleau-Ponty. The characteristic feature of this is a field of tension between, on the one hand, alienation (Sartre) and, on the other hand, a desire for unity and contact (Merleau-Ponty). The pre-reflexive experience of unity is, at times, definitely possible, namely in eroticism and mysticism. In her poetry, Warmond uses the abstraction technique remarkably often. Generally speaking, she uses this technique to generalise individual experiences, feelings and so forth, therefore placing them in a more universal context. An example of this is the so-called "he-poems", written in the masculine, third person singular. Another example is the sex-neutrality in her work. It appears from interviews that Warmond does not consider sex-distinction to be relevant. Her sex-neutral style of writing increases the freedom of interpretation and the reader's possibilities for identification.

After 1970, political commitment becomes more prominent in her work. However, this does not mean a break with existentialist themes. First of all, political commitment was a part of existentialism very early on, and secondly, this aspect could be 
seen in Warmond's work before 1970. At the most there is a shifting of emphasis. Apart from the "melancholic" Warmond there is also a militant Warmond who is aware of her social responsibility as a writer.

\section{Chapters X-XII Mysticism and Existentialism}

A desire for unity, a release from time and space, transformation, a different consciousess and pre-verbal images all play an important part in Warmond's poetry. Up till now I have used the existentialist phenomenology and its related existentialism as an interpretation framework for these experiences. However, these experiences also make one think of mysticism. In this book, mysticism is seen as a literary genre as mystical texts throughout all ages and cultures have shown a great deal in similarity in vocabulary, use of images and ideas. In chapters. X and XII I have placed the two poems, "Voor Wie Uit is op Inkeer" and "Everest/Himalaya" in a mystical context. The so-called empty transcendence, which is supposedly a feature of all modern poetry is not a contemporary western invention but can be found in all ages and cultures, among others in the centuries-old mystical tradition of the via negativa. This also applies to the poetry = mysticism idea: in many ideologies the creation of the world by use of the word plays an important role. This concept for example dominated the mythical or pre-mythical ideas of the ancient world.

In the dyptich, "Voor Wie Uit is op Inkeer", there are two images with a spiritual meaning: the mine and the mountain. The former symbolising the "katabasis", the descent and the latter symbolising the "anabasis" "the ascent. The attainment of either spiritual state, however, is hampered by the noisy intervention of a restless spirit.

Due to the fact that the mountain theme plays an important part in the "Everest/Himalaya" cycle, I first outlined in chapter XI the differences and similarities in the historical appreciation of the mountain in the Eastern and Western world. It is at this point that, among other things, the history of "the sublime" is looked at. Warmond's view of the mountain appears to be a mixture of Eastern and Western elements. The poetry sequence, "Everest/Himalaya", is dealt with comprehensively in chapter XII. This sequence is an example of natural mysticism: landscape and atmosphere evoke and strengthen the experience of timelessness and non-duality.

\section{Chapter XIII Final conclusion and recommendation for further research}

What is Warmond's contribution to literary-existentialism? First of all her work shows that Sartre's conflict model has been wrongly highlighted as the only basic model for existentialism.

Secondly, Warmond has broadened the interpretation of the existentialist liberty theme by blending sexual identity and gender. In her novel categories such as homo/hetero and, or male/female intermingle naturally and playfully. 
Thirdly, Warmond occupies an original position in the canon of "transgression motives": her spirituality is not directed towards "higher" and "further", but towards "below" and "close by". It will only be when "transgression poems" by both male and female poets are examined in more detail and mutually compared, that it can be ascertained whether or not choices such as those made by Warmond are determined by gender.

Translation: Dave Mahoney 


\section{Lijst van geciteerde gedichten van Ellen Warmond}

In de eerste kolom staan de genoemde en/of besproken gedichten van Warmond in alfabetische volgorde. De tweede kolom bevat in verkorte vorm de titel van de bundel waarin het gedicht verschenen is, terwijl de derde kolom verwijst naar de bladzijden waar het betreffende gedicht in deze studie aan de orde komt. Schuingedrukte paginanummers geven aan, dat een gedicht daar uitvoeriger besproken wordt.

De aanduiding a, b of $\mathrm{c}$ in de tweede kolom geeft aan dat het betreffende gedicht ook te vinden is in een of meerdere van de volgende bloemlezingen van Warmonds werk:

$\mathrm{a}=$ Mens: een inventaris (Amsterdam 1960)

$\mathrm{b}=$ Tegenspeler tijd. Een keuze uit de gedichten (Amsterdam 1979)

$c=$ Persoonsbewijs voor imwoner. Een keuze uit de gedichten (Amsterdam 1991)

$1-$ de anderen $=2$

Naar men; a

Weerszij; $a / b$

Geen bloemen

Het struisvogelreservat:

$\mathrm{a} / \mathrm{b}$

Vragen

Proeftuin; $a / b$

De huid; a

De huid; a

De huid; a

Naar men; a

Chanson prèsque triste

Dag dode dichter

De beste compositie is de stilte

De goddelijke divan

De leider spreekt

Denken

De snelkookpan van de tijd 8

Dichter

Dit dan of meer

Dunner
De groeten

Uitzicht

De groeten; b

Geen bloemen; b

Gesloten spiegels

Implosie

Proeftuin; a

Warmte; a

Gesloten spiegels
161

142,152

191-192

195

159-160

162

$140=142$

124

158-159

$122,133,134$,

$157-158,160$

93-94

123

167-168

195-196

211, 244

207, 252

155

133

232 
Eenheid van tijd

(een theatraal beginsel)

Eenvoudig

Eerste en laatste

Everest/Himalaya

Excuus

Focus

Goed gesprek

Groeten uit Vietnam

en omstreken 2

Groeten uit Vietnam

en omstreken 4

Hagepreek

Herkansing I

Humanisme voor kleinbehuisden

In antwoord op uw schrijven

In tenminste twee mensen een

welbehagen

Kleine antropologie

Lao Tse in zakformaat

Leider

Lezen en schrijven

Long gom pa

Naar men zegt

New map of Via Dolorosa

Niets dan dit

Omgekeerd perspectief

Ongeletterd

Op R.C.

Persoonsbewijs voor inwoner
De groeten; $b$

Vluchtstroken; c

Warmte; $\mathrm{a} / \mathrm{b} / \mathrm{c}$

Ordening

Proeftuin; $\mathrm{a} / \mathrm{b} / \mathrm{c}$

Vluchtstroken

Saluutschot

Geen bloemen

Geen bloemen

Weerszij; a/b

Vragen; $c$

Geen bloemen; b

Geen bloemen

De groeten

Warmte; a/b

157

Het struisvogelreservaat;

$\mathrm{a} / \mathrm{b} / \mathrm{c}$

De groeten; $b$

Het struisvogelreservaat; a

Ordening

$120,192-196$

153

230

Naar men; $a / b / c$

118,198

De groeten; b

143-144

Weerszij; a

162

De huid; a/b

133

Warmte; $a / b / c$

75,152

Testbeeld; a

$123-124,126$

Vragen; c 
Plastische chirurgie

Pygmalion

Röntgenologie

Schipbreuk

Slaapwandelen

Slightly drunk

Status

Troost voor psychiaters

Über allen Gipfeln sind Gipfel

Vereenvoudigd

Vereenvoudigde religie

Voor wie uit is op inkeer

Waar of niet?

Wiederaufführung Sternenstunde

Wie zich vergist heeft gelijk

Woonhuis I

Woonhuis II

Ziet/Denkt

Zoals

Zo moet het
Proeftuin; a

Warmte; $a / b / c$

De huid; $\mathrm{a} / \mathrm{b}$

Proeftuin; $\mathrm{a} / \mathrm{b} / \mathrm{c}$

Naar men; a

Testbeeld; a

Testbeeld; $\mathrm{a} / \mathrm{b} / \mathrm{c}$

Geen bloemen

Implosie

230

Het struisvogelreservaat;

$\mathrm{a} / \mathrm{b}$

Naar men; a

$127-134,139,145$, $149,155,161,163$, 251

Uitzicht; b/c

118-119, 198, 203-213, 215, 225 ,

$229,235,237,242$

De groeten

Kaalslag

Kaaistag

Proeftuin; a/b

Proeftuin; a/b

Testbeeld; a

De huid; a

Gesloten spiegels; c
156-157

150-151

188-189

75,149

141

$135=139,162$

139

164 
[ 260] 


\title{
BIBLIOGRAFIE
}

\section{Primaire bibliografie Ellen Warmond}

\author{
A. Poëzie \\ Procftuin. Den Haag 1953 \\ Naar men zegt. Den Haag 1955 \\ Weerszij wan een wereld. Den Haag 1957 \\ Warmite, cen woonplaats. Amsterdam 1961 \\ Het struisvogelreservaat. Amsterdam 1963 \\ De huid als raakvlak. Amsterdam 1964 \\ Testbeeld voor koud klimaat. Amsterdam 1966 \\ Geen bloemen geen bezoek. Amsterdam 1968
}

Mens, een inventaris. Amsterdam 1969 (bevat de bundels Proeftuin; Naar men zegt; Weerszij van een wereld; Warmte, een woonplaats; Het stmisvogelreservaat; De huid als raakvlak; Testbeeld woor koud klimaat)

De groeten aan andersdenkenden. Amsterdam 1970

Saluutschot met knaldemper. Amsterdam 1972

Beestenboel. Versjes voor kinderen met plaatjes van Ton Hoogendoom. Amsterdam 1973

Uitzicht op inzicht. Amsterdam 1974

Implosie. Amsterdam 1976

Tegenspeler tijd'. Een keuze uit de gedichten. Amsterdam 1979

Gesloten spiegels. Amsterdam 1979

Ordening. Amsterdam 1981

Vragen stellen aan de stilte. Amsterdam 1984

Vuchtstroken van de taal. Amsterdam 1988

Persoonsbewijs voor inuoner. Een keuze uit de gedichten. Amsterdam 1991

Kaalslag. Amsterdam 1999

B. Proza

Eeuwig d'uurt het langst. Amsterdam 1961

Paspoort voor niemandsland. Amsterdam 1961

Voorkeur willekeur. Werk van 30 dichters met commentaar. Culemborg 1972

Van kwaad tot erger. Amsterdam 1981

\section{Secundaire bibliografie}

anoniem

'Ellen Warmond schrijft ook proza. Ellen Warmond: Eeuwig duurt het langst.

Paspoort voor niemandsland.' ?

anoniem.

'Ellen Warmond: bekroond dichteres.' Algemeen Dagblad 8-12-1961 
Alphen, Ernst van; Duyvendak, Lizet; Meijer, Maaike; Peperkamp, Ben

Op poètische wijze. Handleiding voor het lezen van poëzie. Bussum/Heerlen 1996 Altena, Ernst van

'Mandarijnen pellen.' Nawoord bij de vertaling van Simone de Beauvoir, De mandarijnen. Amsterdam $1996^{18}: 713-726$

Anbeek, Ton

'Existentialisme in de Nederlandse literatuur: een absurd probleem?' In: Litera-. tuur, Utrecht 1984:4-8

Anbeek, Ton

Na de oorlog, De Nederlandse roman 1945-1960. Amsterdam 1986 Anbeek, Ton

Geschiedenis van de Nederlandse literatuur 1885-1985. Amsterdam $1990^{2}$

Andreus, Hans

Verzamelde gedichten. Amsterdam 1983

Andreus, Hans

De sonnetten van de kleine waanzin. Haarlem 1999

Auwera, Fernand

Engagement of escapisme? Nieuwe gesprekken met Ernst van Altena, J. Bernlef, Jan Christiaens, Miep Diekmann, Jef Geeraerts, Rob van Gennep, Gust Gils, Hella S. Haasse, H.F Jespers, Gerrit Kouwenaar, Hubert Lampo, Ivo Michiels, Harry Mulisch, Ward Ruyslinck, Adriaan van der Veen, Hans van de Waarsenburg, Julien Weverbergh, Paul de Wispelaere. Weesp/Antwerpen 1985

Bakker, Siem (red.)

Nieuwe literatuurgeschiedenis. Overzicht van de Europese letteren van Homerus tot heden. Deel III van 1900 tot heden. Amsterdam 1994

Bal, Mieke

De theorie van vertellen en verhalen. Inleiding in de narratologie. Muiderberg $1986^{4}$ Barrett, Wlliam

Existentialisme. Utrecht/Antwerpen 1971

Bauer, W., Dümotz, J., Golowin, S.

Lexikon der Symbole. Wiesbaden 1980

Beauvoir, Simone de

Le sang des autres. Paris 1943

Beauvoir, Simone de

Oog om oog. Essays. Tricht 1989

Beauvoir, Simone de

De mandarijnen. Amsterdam $1996^{18}$

Berg, J.H. van den

De psychiatrische patiènt. Kleine algemene psychopathologie op fenomenologische grondslag. Nijkerk 1964 
Bergh, H. van den

Konstanten in de komedie. Een onderzoek naar komische werking en envaring. Amsterdam/Antwerpen 1972

Berkelaar, Wim

'Als literatuur vermomde ethiek. Een beschouwing over het literaire existentialisme.' In: Vooys, vol. 15, afl. 1 1997: 29-36

Berlaer-Hellemans, Dina van

'Twee romans uit de Forum-tijd: Hampton Court en Het land van herkomst.' In: Spiegel der Letteren, 1978, jaargang 20, nr. 4, p.241-256

Bernbaum, Edwin

Sacred Mountains of the World. San Francisco 1990

Berthold-Bond, Daniel

'Irony.' In: Gordon 1999:218-220

Bervoets Jan, Ramaer, Hans

'Portfolio. Van kunstenaarsopstand tot engagement. Literatuur en politiek in de jaren zestig.' In: Maatstaf 1989, jg. 37, afl. 8-9, p. 52-84

Bloem, J.C.

Verzamelde gedichten. Amsterdam 1979

Boltendal, R.

Romans van Helma Wolf-Catz en Ellen Warmond.' In: Friese Koerier 18-11-1961

Borchert, Bruno

Mystiek. Het verschijnsel, de geschiedenis, de nieuwe uitdaging. Haarlem 1994 (tweede, bijgewerkte druk)

Bork, G.J. van en Laan, N. (red.)

Twee eeuven literatuurgeschiedenis. Poëticale opvattingen in de Nederlandse literatuur.

Groningen 1986

Bormans Peter

"Ik hoop dat ik stoor." De poèzie van Jan G. Elburg (1919-1992). Brussel z.j. Bos, Ben

"Gesprek met Ellen Warmond. "Ik wil de mensen met mijn poëzie leren dat ze hun nagels en tanden scherp moeten houden." In: De Nieuwe Linie 22-11-1969 Bos, Ben

'Tekst van de radio-uitzending van 9 augustus 1971.' In: Literama, 6e jg., nr. 13, 1971

Boven, Erica van

Een hoofdstuk apart. 'Vrouwenromans' in de literaire kritiek 1898-1930. Amsterdam 1992

Braak, Menno ter

Hampton Court. Amsterdam 1982

Brems, Hugo

Lichamelijkheid in de experimentele poëzie. Bijdrage tot de karakterisering en de lite- 
rair-historische situering van de moderne Nederlandse poëzie 1950-1960. Hasselt: 1976

Brouns, Margo (m.m.v. Verloo, Mieke)

'Kernconcepten en debatten.' In: Vrouwenstudies in de jaren negentig. Bussum 1995 Buelens, Geert

Van Ostaijen tot heden. Zijn invloed op de Vlaamse poëzie. Nijmegen/Antwerpen 2001

Bulthuis, Rico

Ellen Warmond verdwaalt met haar Paspoort voor Niemandsland.' In: Haagsche Courant 28-4-1962

Burnier, Andreas

Mystiek en magie in de litteratuur. Leiden 1988

Calis, Piet, Huygens F.P en Veurman; B.W.E.

Het spel en de knikkers. Kernboek 2. Amsterdam 1975

Calis, Piet

Het ondergronds venvachten. Schrijvers en tijdschriften tussen 1941 en 1945. Amsterdam 1989

Calis, Piet

Speeltuin van de titaantjes. Schrijvers en tijdschriften tussen 1945 en 1948. Amsterdam 1993

Calis "Piet

Het elektrisch bestaan. Schrijvers en tijdschriften tussen 1945 en 1948. Amsterdam 2001

Campert, Remco

'Besprekingen.' In: Braak. Amsterdam 1950/1:20

Campert, Remico

Dichter. Amsterdam 1995

Camus, Albert

De myte van Sisyfus. Een essay over het absurde. Amsterdam 1975

Camus, Albert

De mens in opstand. Amsterdam 1989,

Cruickshank, John

'Levels of Meaning in The Plague. In: Jesse G. Cunningham, Readings on The Plague. San Diego 2001:64-76

Cunningham, Jesse G.

Readings on The Plague. San Diego 2001

Dante Alighieri

De Goddelijke Komedie. Antwerpen/Amsterdam $1977^{3}$ (vertaling C. Kops O.FM.) 
Delfgaauw, B.

Wat is existentialisme? Baarn 1948

Diaz-Diocaretz, Myriam

Jurynapport Anna Bijns Prijs 1987. Den Haag 1987

Dillon, Martin C.

'Sartre ont the Phenomenal Body and Merleau-Ponty's Critique.' In: Jon Stewart 1998:121-143

Dinaux, C.J.E.

'Ellen Warmond.' In: Auteurs uan NU. Gegist bestek, deel III. Amsterdam 1969:85-90

Dondeyne, A.

'Beschouwingen bij het atheïstisch existentialisme.'In: Tijdschrift voor philosophie. Leuven 1951, nr.13, p.1-41

Dresden, S.

Existentiephilosophie en literatuurbeschouving. Amsterdam 1946

Feijter, Anja de

'apocrief / de analphabetische naam'. Het historisch debuut van Lucebert in het licht van de intertekst van Joodse mystiek en Hölderlin. Amsterdam 1994

Fokkema, Douwe en Ibsch, Elrud Het Modernisme in de Europese letterkunde. Amsterdam 1984

Fokkema, R.L.K.

Het komplot der Vijftigers. Een literair-historische documentaire. Amsterdam 1979

Fokkema, Redbad

Aan de mond van al die rivieren. Een gecchiedenis van de Nederlandse poëzie sinds 1945. Amsterdam 1999

Friedrich, Hugo

Die Struktur der modernen Lyrik. Von der Mitte des neunzehnten bis zur Mitte des zwanzigsten Jahrhunderts. Hamburg 1956/1988

Geerts, G., Haeseryn, W., Rooij, J. de en Toorn, M.C. van den Algemene Nederlandse Spraakkunst, Groningen/Leuven 1984

Gennep, F.O. van

Albert Camus. Een studie van zijn ethische denken. Amsterdam $1966^{2}$

Goedegebuure, Jaap

'Postmoderne modernisten en modernistische postmodernen. Nederlandstalige schrijvers van de twintigste eeuw herlezen.' In: Nederlandse Letterkunde, jg. 6, nr.1 januạri 2001:13-32

Goethe, J.W. von

Gedichte Poëtische Werke I. Berlin 1976

Govaart, Th.

'De wereld als opgave.' In: Kultuurleven. Antwerpen 1961/8:596-609 
Greshoff, Jan

"Paspoort voor niemandsland". In roman van E. Warmond zijn intellect en emotie innig vervlochten.' In: Het Vaderland 14-4-1962

\section{Hanssen, Léon}

Sterven als een polemist. Menno ter Braak 1902-1940. Deel II 1930-1940. Uitgeverij Balans 2001

Hartgers, Rob

'Vrolijk existentialisme.' In: Folia 26, jr. 55, 8 maart 2002, p. 16

Happold, F.C.

Mysticism. A Study and an Anthology. Londen 1990 (tweede herziene druk)

Hermans, W.F.

‘Stelt Nederland belang in Sartre?' In: Criterium 1945-1946/13, p.713-715

Heinemann, Fritz

Existentiefilosofie: levend of dood? Utrecht-Antwerpen 1967

Henricks, Robert G.

The Poetry of Han-shan. A Complete, Annotated Translation of Cold Mountain. New York 1990

Heynders, Odile

'Paul Rodenko. Orensnyder tulpensnyjder. Verzamelde gedichten.' In: Lexicon van Literaire Werken. Gromingen 1994

Heynders, Odile

Langzaam leren lezen. Paul Rodenko en de poëzie. Tilburg 1998

Heyting, L.

'Ik sla niet meer zo hard op tafel.' In: NR.C Handelsblad 10-8-1979

Hillary, Ed.

Ik stond op de Everest. Amsterdam 1957

Hofland, H.J.A. en Rooduijn, Tom

Duars door puinstof heen. Grondleggers van de naoorlogse literatuur. Met documentaire over de Vijftigers op cd. z.p. 1997

Hoof, Guy van

'Tegenspeler tijd.' In: Argus. Sint-Truiden 1981:415-417

Hoornik, Ed.

Verzamelde gedichten. Amsterdam 1972

Hutcheon, Linda

Irony's Edge. The Theory and Politics of Irony. London/New York 1995

Hynes, Samuel

The Auden Generation. Literature and Politics in England in the 1930s. Princeton $1976^{2}$ 
Idema, W.L.

Spiegel van de klassieke Chinese poëzie van het Boek der Oden tot de Qing-dynastie. Amsterdam 1991

Irigaray, Luce

'The Invisible of the Flesh: A Reading of Merleau-Ponty, The Visible and the Invisible, "The Intertwining -The Chiasm"'. In: An Ethics of Sexual Difference. Ithaca 1993: 151-184

James, William

The Varieties of Religious Experience. A Study in Human Nature. New York 1999 (eerste editie 1902)

Jong, L. de

Het koninkrijk der Nederlanden in de Tweede Wereldoorlog. Deel 12 Epiloog eerste helft. Den Haag 1988

Kamerbeek, J.

De poëzie van J.C. Bloem in Europees perpectief. Amsterdam 1979

Kamp, Truusje van de

'Scheppen in de luwte van de taal. Over Ellen Warmond.' In: Prinssen, M. en Vermeij, Lucie Th, 1991

Keats, John

The Poetical Works of John Keats. London 1950

Kern, Edith

Existential Thought and Fictional Technique. Kierkegaard, Sartre, Beckett. New Haven and London 1970

Kierkegaard, S.

Over de vertwiffeling. De ziekte tot de dood. Utrecht-Antwerpen 1963

Knuvelder, G.

Beknopt handboek tot de geschiedenis der Nederlandse letterkunde. Den Bosch $1982^{10}$

Kouwenaar, Gerrit

Gedichten 1948-1978. Amsterdam 1982

Krishnamurti, J:

You Are the World. New York 1972

Kroon, Dirk

'Dichteres van het desondanks.' In: Kultuurleven. Antwerpen 1980:506-510

Kusters, Wiel

De killer Over poëzie en poëtica van Gerrit Kouwenaar. Amsterdam 1986.

Kusters, Wiel

'Nijhoff, Bloem, Rilke.' In: De nieuwe taalgids 81-2, 1988:178

Kusters, Wiel

Pooltochten. Amsterdam 1989 
Kusters, Wiel

'Poëzie, wrede machine.' In: Kusters, Wiel, Ik graaf, jij graaft. Aantekeningen over poëzie. Amsterdam 1995:140-147'

Kusters, Wiel

'Over het beklimmen van de Parnassus.' In: Literatuur, afl. 2, 1996: 86-91

Kwant, R.C.

Fenomenologie var de taal. Utrecht/Antwerpen 1963

La Belle, Jenijoy:

Herself Beheld. The Literature of the Looking Glass. Ithaka/London $1989^{2}$

Lao Tze

Tau Te Tsjing. Den Haag z.j.

Lemaire, Ton

Filosofie van het landschap. Baarn $1970^{5}$

Lemaire, Ton

Met open zinnen. Natuur, landschap, aarde. Amsterdam 2002

Luijpen, W.

Nieuwe inleiding tot de existentiele fenomenologie. Utrecht/Antwerpen 1969

Manakata, Kiyohiko

Sacred Mountains in Chinese Art. Urbana/Chicago 1991

Marissing, Lidy van

'Ellen Warmond. Doodsbang voor "gevoelspoëzie". In: de Volkskrant 16 maart 1968

Marja, A.

'Angst bezwering volledigheid. Lucebert, Hans Andreus, Ellen Warmond.' In:

Poëzieproeven: over dichters, gedichten, beweegredenen, resultaten. Den Haag. 1963:96-104

Mazis, Glen A.

'Touch and Vision: Rethinking with Merleau--Ponty Sartre on the Caress.' In: Jon Stewart 1998:144-153

Merleau-Ponty, Maurice

Fenomenologie van de waarneming. Amsterdam 1997

Mertens, Anthony

'28 juni 1969 Première van de opera Reconstructie. Het politiek-maatschappelijke klimaat in de jaren zestig.' In: M.A. Schenkeveld-van der Dussen (hoofdred.), Nederlandse literatuur, een geschiedenis. Groningen 1993: 807-813

Meijer, Maaike

De lust tot lezen. Nederlandse dichteressen en het literaire systeem. Amsterdam 1988 Michaelis, Hanny

Verzamelde gedichten. Amsterdam. 1996 
Mommaers, Paul en Bragt, Jan van

Jan van Ruusbroec in gesprek met het Oosten. Mystiek in boeddhisme en christendom. Kampen 1995

Mooij, A.

Taal en verlangen. Lacans theorie van de psychoanalyse. Meppel $1997^{7}$

Morreall, John

'Humor.' In: Gordon 1999:188-191

Murdoch, Iris

Existentialists and Mystics. Writings on Philosophy and Literature. New York 1997

Nahas, Hélène

La femme dans la littérature existentielle. Parijs 1957

Nicholson, Marjorie Hope

Mountain Gloom and Mountain Glory. The Development of the Aesthetics of the Infinite. Seattle/London 1997 (oorspronkelijk verschenen in 1959)

Opheten, F

Op zoek naar evenvicht. De filosofische onturikkeling van J.C. van Schagen in de twintiger jaren. Leiden 1983

Osborne, Charles

W.H. Auden. The Life of a Poet. New York 1995

Pelgrom, $\mathrm{H}$.

Ellen Warmond en het existentialisme. Ongepubliceerde scriptie G.L.A. 1974

Perk, Jacques

Gedichten. Tiende en geheel volledige uitgave bezorgd door Willem Kloos. Amsterdam 1911

Perre, Rudolf van der

'Ellen Warmond. Zo elke mens. Een kreet om warmte.' In: De gekleurde wereld. Brugge 1979:139-143

Petrarca, F

De top van de Ventoux. Vertaald en van aantekeningen voorzien door Chris Tazelaar. Baarn 1990

Praz, Mario

The Romantic Agony, Oxford 1985

Prinssen, M. en Vermeij, Lucie Th.

Schrijfsters in de jaren vijftig. Amsterdam 1991

Radhakrishnan, $\mathrm{S}$.

Eastern Religions and Western Thought. Oxford 1939

Rauch, Leo

'Sartre, Merleau-Ponty, and the "Hole in Being".' In: Jon Stewart 1998:1-15 
Redeker, Hans

Existentialisme. Een doortocht door philosophisch frontgebied. Amsterdam 1949

Renders, Hans

Braak. Een kleine mooie revolutie tussen Cobra en Atonaal. Met een facsimile uitgave van het tijdschrift. Amsterdam 2000

Rilke, R.M.

Werke Band II-1 Gedichte und Übertragungen. Frankfurt am Main $1984^{3}$

Rodenko, Paul

Verzamelde essays en kritieken. Deel 1. Amsterdam 1991

Rodenko, Paul

Verzamelde essays en kritieken. Deel 2. Amsterdam 1991

Rodenko, Paul

Verzamelde essays en kritieken. Deel 3. Amsterdam 1992

Rodenko, Paul

Verzamelde essays en kritieken. Deel 4. Amsterdam 1992

Royle, Peter

'Irrationalism.' In: Gordon, Haim, 1999:221-225

Rubinstein, Renate

'Ellen Warmond als prozaschrijfster.' In: NRC 25-11-1961

Ruiter, Frans en Smulders, Wilbert

Literatuur en moderniteit in Nederland 1840-1990. Amsterdam 1996

Sartre, Jean-Paul

Being and Nothingness. A Phenomenological Essay on Ontology. Translated and with

an introduction by Hazel E. Barnes, University of Colorado. New York. 1984 (vertaling van L'être et le néant 1943)

Sartre, Jean-Paul

De wegen der vrijheid II Het oponthoud. Amsterdam/Antwerpen 1952

Sartre, Jean-Paul

De vliegen / Met gesloten deuren / De eerbiedige lichtekooi / Viuile handen. Amsterdam 1965

Sartre, Jean-Paul

Over het existentialisme. Utrecht 1967 / 1985

Sartre, Jean-Paul

Het Ik is een Ding. Meppel/Amsterdam $1988^{2}$

Sartre, Jean-Paul

'What is Literature?' and Other Essays. Cambridge 1988

Sartre, Jean-Paul

Walging. Amsterdam $1990^{11}$

Sawicki, Jana

'Literature.' In: Gordon, Haim, 1999:269-273 
Schenkeveld-van der Dussen, M.A.

Nederlandse Literatuur, een geschiedenis. Groningen 1993

Schipper, Kristofer

Tao. De levende religie van China. Amsterdam $1989^{2}$

Schokker, J. en T.

Extimiteit. Jacques Lacans tenugkeer naar Freud. Amsterdam 2000

Scholten, Harry

Lyriek is de moeder der politiek. Opvattingen over poëzie en maatschappelijk engagement in de dichtersbeweging der Vijftigers.' In: Literatuur, Utrecht 1984:13-18

Schram, D.

'Taal behoudt de feiten. De verwerking van de Tweede Wereldoorlog in de literatuur.' In: Schram, D.H. en Geljon, C. 1990:93-126

Schram, D.H. en Geljon, C.

Overal sporen. De venwerking uan de Tweede Wereldoorlog in literatuur en kunst. Amsterdam 1990

Schuyt, Kees, Taverne, Ed

1950 Welvaart in zwart-wir. Nederlandse cultuur in Europese context deel IV. Den Haag 2000

Simons, W.J.

'Kroniek der poëzie.' In: Amsterdams tijdschrift voor letterkunde. Amsterdam 1953:134-137

Smeets, S.

'Over de receptie van het existentialisme in Nederland.' In: Studium Generale reeks, Bureau Studium Generale, Universiteit Utrecht 1997:113-133

Smelik, K.A.D., Lodders, G., Tempelaars, R.

Etty: de nagelaten geschriften van Etty Hillesum, 1941-1943. Amsterdam 1986

Sneller, A. Agnes en Verbiest, A.

Wat woorden doen. Cursusboek genderlinguistiek. Bussum 2000

Sötemann, A.L.

Over poëtica en poëzie. Groningen 1985

Staal, Frits

Het wetenschappelijk onderzoek van de mystiek. Utrecht/Antwerpen 1978

Stassaert, Lucienne.

'Waarom schrijven vrouwen gewoonlijk slecht?' In: De Vlaamse Gids, 56, november, 11, p. $4-13$

Stewart, Jon

The Debate between Sartre and Merleau-Ponty. Evanston 1998

Stewart, Jon

'Merleau-Ponty's Criticisms of Sartre's Theory of Freedom.' In: Jon Stewart 1998:197-214 
Stokvis, Willemijn

Cobra. Geschiedenis, voorspel en betekenis van een beweging in de kunst van na de tweede wereldoorlog. Amsterdam 1985

Stralen, Hans van

Beschreven keuzes. Een inleiding in het literaire existentialisme. Leuven-Apeldoorn 1996

Stralen, Hans van

'Zelfontplooiing en scepsis. De filosofie en de literatuur van het existentialisme na de Tweede Wereldoorlog.' In: Jaarboek voor literatuunvetenschap I 1998:85-96 Struyker Boudier, Henk

Speurtocht naar een onbekende. Anna Blaman en haar Eenzaam avontuur. Amsterdam $1978^{2}$

Thüsen, J. von der

'De vulkaan. Collectieve waarneming en symbolisering in de achttiende eeuw.' In: R. Engbersen, Th. Jansen, W. Witteveen (red.), Het retorische antwoord. Utrecht 1991

Unsworth, Walt

Everest. The Utimate Book of the UTtimate Mountain. London $199 \mathrm{I}$

Vanheste, Bert

Existentialistische literatuur. Een absurd probleem of een niet zo zinvolle oplossing?' In: Literatuur 1992, afl. 3, 144-150

Vegt, Jan van der

'Skepsis in het kwadraat.' In: Ons erfdeel. Rekkem 1971:114-115

Vegt, Jan van der

'Kijken in een gesloten spiegel.' In: Ons erfdeel. Rekkem 1981/5:655-664

Vegt, Jan van der

'Ellen Warmond.' In: Kritisch Literatuur Lexicon. Groningen 1984

Verhoeven, Cornelis

Het medium van de waarheid. Beschouwingen over Plato's houding tegenover de poëzie.

Baarn 1988

Vervaeck, Bert

'Essay en vertelling in postmoderne tijden.' In: Nederlandse Letterkunde, jg. 6, nr. 4, november 2001:289-309

Vestdijk, Simon

Mnemosyne in de bergen. Een episch gedicht in negen zangen. Den Haag $1960^{2}$

Vogel, Marianne

Baand boven baard. Over het Nederlandse literaire en maatschappelijke leven 1945-1960. Amsterdam 2001 
Vuyk, Bep

'Twee boekjes van Ellen Warmond. Geen paspoort voor de eeuwigheid.' In: Vrij Nederland 13-1-1962

Watering, C.W. van de

Met de ogen dicht. Een interpretatie van enkele gedichten van Lucebert als toegang tot diens poëzie en poética. Muiderberg 1979

Wentworth, Harold en Berg Flexner, Stuart

The Pocket Dictionary of American Slang. New York 1968

Wesseling, Lies

'Van ideeëngeschiedenis naar cultuurgeschiedenis. Over de ontwikkelingsgang van een interdisciplinaire onderzoekspraktijk.' In: Tijdschrift voor literatuurgeschiedenis 1 1998: 49-65

Wieg, Rogi

'Ieder mens is zijn eigen centrum.' In: de Volkskrant 7-10-1988

Wit, Han F. de

De verborgen bloei. Over de psychologische achtergronden van spiritualiteit. Kampen $1998^{8}$

Wijk, Trudy van

"'Je wordt wat ouder en wat dommer."' Een exclusief interview met Anna Bijns Prijs-winnares Ellen Warmond.' In: Opzij november 1987

IJzer, Meta van

'Ellen Warmond. Ontmoeting in proza.' In: Jeugd en cultuur. Brussel 1964/7, p. $316-319$

IJzer, Meta van

'Ellen Warmond. Zes poëtische ontmoetingen.' In: Jeugd en cultuur. Brussel 1965:267-277

IJzer, Meta van

'Marmeren status versus hanig zijn. Teksten aan de wand in een welvaartsstaat.' In: Jeugd en cultuur. Oudenaarde 1967:128-135 
[274] 


\section{CURRICULUM VITAE}

Trudy van Wijk werd op 23 december 1951 geboren te Amsterdam. In 1977 behaalde zij de akte Nederlands MO-A, in 1983 de akte Nederlands MO-B en in 1988 het doctoraal examen Nederlandse taal- en letterkunde aan de Universiteit van Amsterdam. Zij was van 1979 tot 2000 werkzaam in het middelbaar onderwijs. 
[276] 


\section{REGISTER VAN PERSONEN}

Achterberg 185, 200

Adama van Scheltema 181

Aertsens 200

Anbeek 15-16, 19-24, 26, 30,

113-114, 185

Andreus 74, 113, 222

Armando 32

Auden 181

Augustinus 218

Auwera 186

Baudelaire 199

Beauvoir, de $16,18,28,31,33,78$, $106,119,177-178$.

Beckett 46-47

Belle, La 124, 126

Berg, van den 138

Bernbaum 219

Bervoets 186

Blaman 18, 21, 31', 34, 37, 108-111

Bloem 237

Böll 31

Bontridder 116

Boon 115

Borchert 247

Bork 21, 113

Bormans 181, 196

Boven, van 171

Braak, ter 15, 22-23

Brabander, den 184

Brems 151, 154

Breton 151

Brouns 172

Buber 248

Buelens 115

Bulthuis 108-109

Burnet 215

Burnier 156, 231

Calis 17,115
Calvijn 215

Campert 17, 33, 114, 123, 216

Camus 15, 17-22, 25, 31-32, 36-37. $39,65,88-89,91,106,117,119,137$, 142,177

Céline 19

Chirico, de 136, 149

Christiaens 115

Claus 17, 114-115

Cohen Solal 113

Confucius 209

Daalen, van 222

Dante 30, 217

Debrot 185

Degas 224

Delfgaauw $15-16,21,30$

Dèr Mouw $198^{\circ}$

Diekmann 173

Donovan 33

Doolaard, den 221-222

Dostojevski 19, 29

Dresden 16, 26

Dylan 33

Eckhart 202-203

Eeden, van 181

Elburg 180, 196

Ensing 172

Evagrius van Pontus 208

Everest 243

Faulkner 19

Feijter, de 200

Flaubert 47

Fokkema 114, 181-182

Franciscus van Assisi 223, 247

Friedrich 199-200

Gauguin 224

Gilliams 198

Goedegebuure 25, 31 
Goethe, von 230, 237

Gogh, van 224

Gogol 19

Gorter 181, 222

Greene 19, 36

Greshoff 108-110

Hadewijch 247

Han-shan 211

Happold 199

Hattum, van 184, 186

Heidegger 35,91

Heijermans 181

Hemingway 19

Hermans $16-17,21,34-35,108$

Heynders 116-117

Hillary 227

Hillesum 231

Hockstra 185

Hofland 17

Hokusai 224

Holliday 97

Hoornik 182, 184, 186

Hutcheon 59

IJzer, van 108

Irvine 221

James 247

Jaspers $26,35-36,38,62,91$

Jorn 151

Jung 231

Kamp, van de 110

Keats 167

Kern $45,47-49,249$

Kierkegaard 26-27, 35-36, 46-47, 62 Ostaijen, van 198-199

Kipling 228

Knuvelder 24

Koestler 19

Kousbroek 17

Kouwenaar 17, 33-34, 48, 114, 117, $182,198,222$

Morriën 170,172
Krishnamurti 207

Kusters 17, 48, 116

Laan 21,113

Lacan $74,125,133$

Lages 191

Lao Tze 230, 232

Lemaire 220, 223

Li Bai 223

Lucebert 20, 180, 198, 200, 205

Luijpen 43

Luther 216

Magritte 136

Mallarmé 199

Mallory 221

Manet 224

Marcel 26, 36

Mazis 43

Meijer 139, 165, 187, 198, 205

Merleau-Ponty 40-42, 44, 48, 66, 76, $78,111,121,126,132,138,153,225$, 249-250

Michaelis 182, 187

Mok 182

Molen, van der 114-115

Mulisch 32-33, 187

Murdoch 27,34

Nicholson 219

Nietzsche 27

Nijhoff 199

Noordzij 109, 187

Nooteboom 222

Pascal 31

Peijpers 187

Pelgrom 119-121, 188

Petrarca 218

Peursen, van 16 
Plato 178

Polet 182

Rabelais 63

Ramaer 186

Redeker 16

Reve 20-21, 108

Rilke 129

Rimbaud 199, 205

Robberechts 173

Rodenko $19,22,113,116,200,202$, 205,240

Roland Holst, A. 198

Roland Holst, H. 181

Romein-Verschoor 18

Rooduijn 17

Rubinstein 108-109

Ruiter 25

Ruskin 218

Russ 171

Ruusbroec 202, 248

Samkalden 192

Sappho 165,167

Sartre $15-23,25-26,28,30-31,33$, $35-37,39-44,47-48,64,67,76,78$, $85,91-92,100,103,106,113-114$, $116-117,119,132,142,145,154$, $178-179,190,210,249$

Schagen, van 211

Schierbeek 17, 33, 48, 114, 116-117, 154

Schipper 232

Scholten 180

Schram 32

Sédar-Senghor 180

Sierksma 21

Smith 97, 143

Smulders 25

Sötemann 199, 236

Stassaert 173

Stirner 189 ..
Stralen, van $11-12,22,25,27,29$, $31-38,40,45,48-49,85,92,104,116$, $120-121,178,249$

Struyker Boudier 111

Teister 182

Tenzing Norgay 227

Thüsen, von der 220

Tsjechov 19

Vanheste $17,21,23,26-27,113$

Vasalis $35,48,116-117,185-187,198$

Vegt, van der $110,117,119,135-136$, 139,198

Verwey 222

Vestdijk 15, 222

Voeten 182

Vogel 107-108, 110, 172

Vree, de 116

Vreede, de 187

Vries, de 216

Vuyk 109

Waarsenburg, van de 182,186

Walravens 115

Warmond 35, 39, 48-49, 52, 55-57, $60-61,67,74-75,79,82,84,93,104$, $106,108-111,116-117,119-121,123$, $126-127,129,131,134,139-140,145$, $149,153-155,159-161,163,165$, $168-169,172-173,182,186-188,191$, $197,203,210,215,222,227,238$,

$241,243,249,251$

Watering, van de 200-203, 245

Waugh 243

Whitman 236

Wieg 169

Wolf-Catz 108 


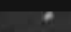

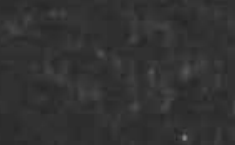

